\author{
Szegedi Tudományegyetem \\ Természettudományi és Informatikai Kar \\ Földtudományok Doktori Iskola \\ Gazdaság- és Társadalomföldrajz Tanszék
}

\title{
A térbeliség és a lokalitás szerepe a periférikus területeken élö hátrányos helyzetúek munkahelymegtartó képességében
}

Doktori $(\mathrm{PhD})$ értekezés

Rozgonyi-Horváth Ádám

Témavezető

Dr. Boros Lajos, egyetemi docens

Szeged

2019 


\section{Tartalomjegyzék}

Bevezetés 1

1. A dolgozat célja és föbb kérdései..................................................................................3

2. A kutatás elméleti és fogalmi háttere .....................................................................................5

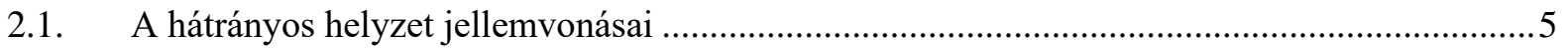

2.2. A periférikus területek és a szegregátumok földrajzi és társadalmi jellemzöi ........................... 6

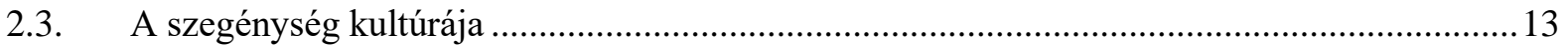

2.4. Magyarország periférikus területein és szegregátumaiban élők szegénység kultúrájához

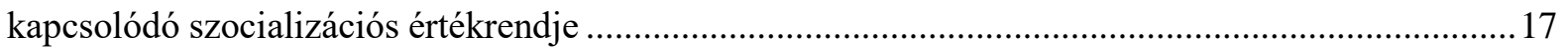

2.5. Periférikus területek és az ott élők társadalmi helyzetének kialakulása ..................................19

2.6. A periférikus területek munkaerö-piaci helyzete és nehézségei .............................................22

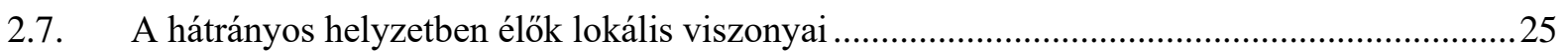

2.8. A periférikus területek és az alternatív munkaeröpiac kapcsolata ..........................................26

2.9. Közfoglalkoztatás munkaerő-piaci (re)integrációs hatása ........................................................28

3. A kutatás földrajzi területe ................................................................................................32

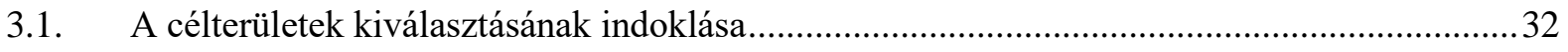

3.2. Az Észak-Alföld és Jász-Nagykun-Szolnok megye gazdaság- és társadalomképe ..................33

3.3. Tiszabő, a rurális jellegü periférikus térségek mintaterülete ………..........................................38

3.3.1. Tiszabö földrajzi elhelyezkedése és lakossági összetétele ..............................................38

3.3.2. A falu szegregálódási és periferizálódási folyamata.................................................... 40

3.3.3. Tiszabö gazdaságának és a falubeliek munkaerö-piaci helyzetének alakulása ...............44

3.4. A szolnoki Törteli úti szegregátum, a városi jellegü periférikus térségek mintaterülete..........47

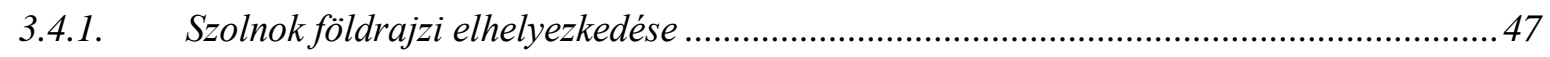

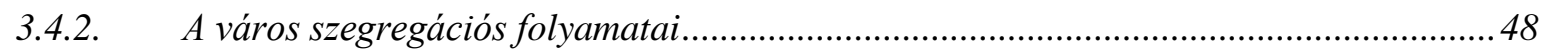

3.4.3. Törteli úti szegregátum elhelyezkedése és Déli iparterület városrész..............................49

3.4.4. A Törteli úti telep szegregálódási folyamata és az ott található ingatlanok helyzete ......50

3.4.5. A Törteli úti telep háztartásainak helyzete és összetétele ...............................................55

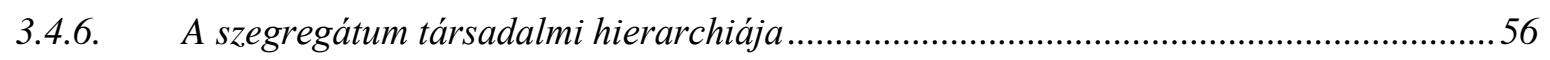

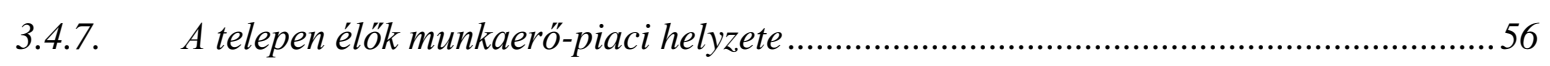

4. A kutatás módszertani alapjai ............................................................................59

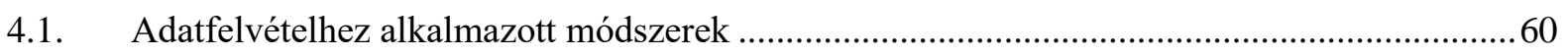

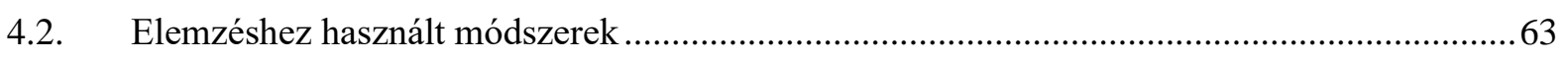

5. A mintaterületeken végzett kutatás eredményei ...............................................64

5.1. Tiszabő demográfiája, a faluban élők iskolai végzettsége és jövedelmi helyzete a munkaerőpiaci szerepvállalás aspektusából. 
5.2. A szegénység kultúrájának hatása a tiszabői hátrányos helyzetủek hosszú távú munkahelymegtartására

5.3. A rurális jellegü periférikus területek földrajzi és infrastrukturális jellemvonásainak munkaerö-piaci hatásai

5.4. Területi stigma és a kapcsolati tőke szerepe a rurális jellegü periférikus területeken élők munkaerö-piaci szerepvállalásban

5.5. A közmunkaprogram hatása a szegénység kultúrájára és a hátrányos helyzetüek elsődleges munkaerő-piaci integrációjára

5.6. A szolnoki Törteli úti szegregátumban élők demográfiája, iskolai végzettsége és jövedelmi helyzete a munkaerő-piaci szerepvállalás aspektusából

5.7. A szegénység kultúrájának hatása a szegregátumban élő hátrányos helyzetűek hosszú távú munkahelymegtartására

5.8. A centrumhoz közeli periférikus területek földrajzi és infrastrukturális jellemvonásainak munkaerő-piaci hatásai

5.9. Területi stigma és a kapcsolati tőke hatása a centrumhoz közeli periférikus területeken élők munkaerő-piaci szerepvállalására .

5.10. A közmunkaprogram hatása a szegénység kultúrájára és a hátrányos helyzetűek elsődleges munkaerő-piaci integrációjára

6. Összegzés és következtetések ..........................................................................................104

6.1. A mintaterületek összehasonlítása a kutatási kérdések tükrében ............................................ 104

6.2. Az eredmények gyakorlati jelentősége és hasznosíthatósága ..............................................112

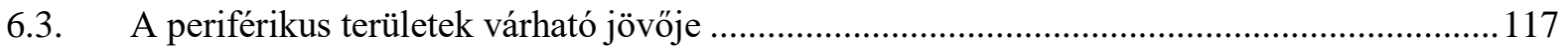

Felhasznált irodalom ........................................................................................................120

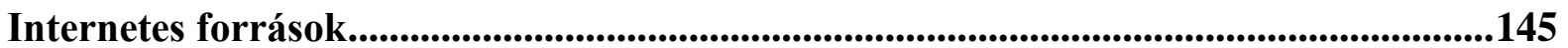

Egyéb források ..........................................................................................................................148

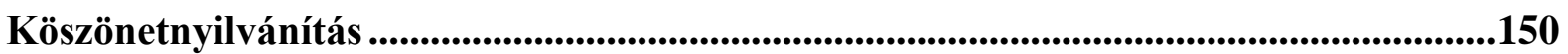

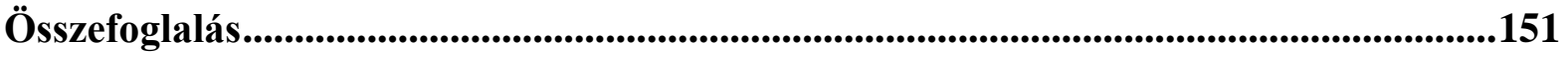

Summary

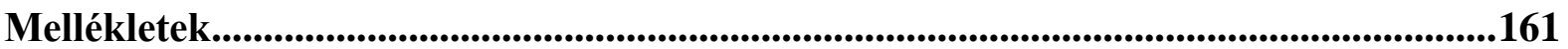

Melléklet 1. - A magyarországi telepfelszámolás és a CS-lakások építésének folyamata ................... 161

Melléklet 2. - Az adatfelvételhez használt kérdőívek ........................................................................ 163

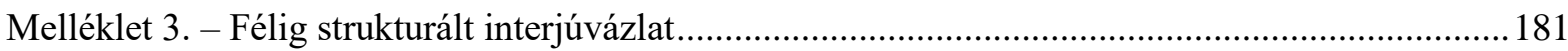

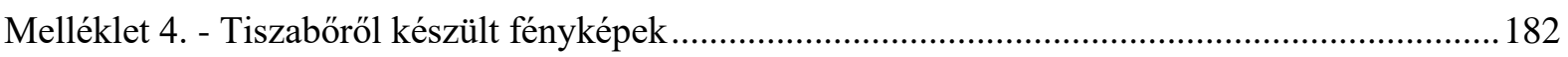

Melléklet 5. - Szolnok, Törteli úti szegregátumról készült fényképek ............................................ 190 


\section{Bevezetés}

A hátrányos helyzetü emberek munkaerő-piacon való elhelyezkedési nehézségei gyakori vizsgálati téma Magyarországon. E csoport elsősorban a periférikus területeken felülreprezentált, ezért ezen térségekben tapasztalható munkanélküliség jóval magasabb a hazai átlagnál (ALPEK-TÉSITS 2017A, TímÁR et al. 2015). Ennek egyik oka, hogy a rendszerváltás előtti időszakban a mezőgazdasággal, vagy iparral foglalkozó állami vállalatoknál el tudtak - és el is kellett - helyezkedni a végzettség, és képesítés nélküli emberek (Kertesi 2000B, TARKOWSKA 1997, PÁSZTOR-PÉNZES 2012), de a rendszerváltást követően vagy privatizálták ezeket a cégeket (KovÁCS et al. 2007), vagy megszüntek. A piacgazdaság kialakulásával a munkaerőpiac teljesen átstrukturálódott (KISS-SZALKAI 2018, KULCSÁR et al. 2011), és az alacsony iskolai végzettséggel (KOLARCIK et al. 2009, VASECKA-RADICOVA 2000) rendelkezö, szakképzetlen emberek voltak az elsők, akik kiszorultak a mezőgazdaság, a bányászat, az építőipar, vagy éppen a nehéz- és a könnyüipar területén található munkahelyekről (KERTESI 1995, KLIGMAN 2001, OBÁDOVICS et al. 2012, KEMÉNY et al. 2004). Ezért ezeknek a családoknak a bevételeik jelentősen csökkentek (BRADBURY-JANTTI 1999), amelynek eredményeként a rendszerváltást követően drasztikusan megnőtt a szegénység (MAGYARI et al. 2001, LADÁNYI 2001, MiTEV et al. 2001). A munkanélküliség helyett tömegek menekültek a szerény, de állandó jövedelmet biztosító inaktivitásba, amelyre a korengedményes- és a rokkantnyugdíj lehetőséget nyújtott (PÉNZES 2010), így a korábban a társadalomban integrálódott rétegek alig néhány év alatt újra a társadalmon kívülre szorultak (KERTESI 2000A). Ez pedig életük minden területén - oktatás, jövedelem, munkalehetőségek, biztonság, egészség - érezteti hatását (SAMMAN-SANTOS 2013, RAPHAEL 2002), és a magasabb iskolai végzettség megszerzése nélkül (CSONGOR 1993, UNICEF 2007) a ma aktív korú gyermekeik is csak átöröklik a munkanélküliséget és újratermelik (EMIGH et al. 2001, NAGY et al. 2015A) a szülők szegénységét és szociális helyzetét (LISKÓ 2001).

Mindezek következtében manapság már a második generáció nő fel olyan szocializációs környezetben, amely a mélyszegénység viszonyainak túlélésére rendezkedik be. A magyar jóléti modell 2010-es években történt szociál- és foglalkoztatáspolitikai szemléletváltásának (Koós 2016) eredményeként a jelenlegi feltételek egy felajánlott munkalehetöség - ami a legtöbb esetben közfoglalkoztatás kötelező elfogadásán keresztül kondíciókhoz kötik a támogatások kifizetését (TíMÁR et al. 2015), tehát munkával próbálják biztosítani számukra a megélhetést. Kérdés, hogy ezzel lehet-e csökkenteni a társadalmi lemaradást és a szegénység kultúrájához 
kapcsolódó normák hatásait, vagy az ilyen környezetben és értékek között szocializálódott generációk kitörése továbbra is megoldatlan marad?

A kutatás során célom volt, hogy megvizsgáljam azokat a területi jellemzőket, amelyek leginkább hatással vannak a periférikus területeken élők munkaerő-piaci szerepvállalására, illetve feltárjam, ezen tulajdonságok milyen kölcsönhatásban vannak a szegénység kultúrájára jellemző lokális szokásokkal.

A dolgozat hét fö egységre osztható. Az első részben a kutatás célját és főbb kérdéseit mutatom be, majd a kutatás elméleti háttérébe nyújtok betekintés, amely során áttekintem a vonatkozó hazai és nemzetközi szakirodalmat, ismertetem a periféria fogalmi rendszerét, valamint a szegénység kultúrájának elméletét, és a hozzá kapcsolódó értékrendet. Korábbi kutatások eredményei alapján kitérek a periférikus területeken élők munkaerő-piaci nehézségeire, helyi viszonyrendszerére, valamint a közfoglalkoztatás által nyújtott lehetőségekre és ennek korlátaira. A dolgozat harmadik részében a kutatási célterületek kiválasztásának indoklása mellett ezen földrajzi területek bemutatásával folytatom, kezdve a két mintaterületet magába foglaló Észak-Alföld régióval és JászNagykun-Szolnok megyével. Majd a belső periférikus területek helyzetét reprezentáló falu, Tiszabő földrajzi-, helytörténeti-, gazdasági- és társadalmi ismertetése következik, amelyet a centrumhoz közeli, városi perifériát megtestesítő terület, a szolnoki Törteli úti szegregátum hasonló szempontok szerinti bemutatása követ. A következő fejezetben áttekintem a kutatás értelmezése szempontjából legfontosabb alapfogalmakat, majd a vizsgálat módszertani alapjait ismertetem. A disszertációban alkalmazott tudományos módszerek alapvetően kvantitatív adatgyüjtésre épülnek, amelyeket kvalitatív adatgyüjtési technikákkal egészítettem ki. A hatodik részben a kutatásom során szerzett adatok elemzésének eredményeit mutatom be, amelyben munkaerő-piaci szerepvállalás perspektívája szerint kitérek a mintaterületeken élők demográfiai helyzetére, jövedelmi viszonyaira, valamint a szegénység kultúrájának jelenlétére, illetve a vizsgált periférikus területek földrajzi és infrastrukturális sajátosságainak következményeire. A közmunkaprogram hatását egyrészt a szegénység kultúrájának elméleti kereteiben ismertetem, másrészt az elsődleges munkaerő-piaci szerepvállalás szempontjából elért eredményei kerülnek ismertetésre. A hetedik, záró fejezet a mintaterületek egymással való összehasonlítását, a kutatás eredményeinek összegzését és a szakirodalmi tartalmakkal való összevetését hivatott bemutatni. Emellett a kutatás kérdései is megválaszolásra kerülnek, amelyet az eredmények gyakorlatban történő hasznosításának lehetőségeire vonatkozó javaslatok követnek, ezután a periférikus területek várható jövőjével kapcsolatos gondolatok zárják a dolgozatot. 


\section{A dolgozat célja és főbb kérdései}

A disszertációmhoz kapcsolódó kutatás során megvizsgáltam, munkaerő-piaci szerepvállalásuk alapján milyen személyes, egyéni tényezők jellemzik a periférikus területeken élő hátrányos helyzetü embereket, és milyen lokális és területi sajátosságok hatnak az ilyen térségekben élők munkaerő-piaci integrációjára. Tehát a kutatás célja volt feltárni, mely jellemvonások befolyásolják leginkább a periférikus területeken élő emberek elhelyezkedési lehetőségeit és munkahelymegtartó-képességét, valamint megvizsgálni, ezek a tényezők hogyan kapcsolódnak az Oscar Lewis esettanulmányai által bemutatott szegénység kultúrájához (LEWIS 1959, 1965, 1966, 2000).

Természetesen ahhoz, hogy a mind társadalmi-, mind pedig földrajzi értelemben kirekesztett emberek vagy csoportok meg tudják tartani munkahelyüket, először munkához kell jutniuk, amelyhez munkahelyek is szükségesek, méghozzá olyan állásokkal, amelyek nem igényelnek szakképzettséget, hiszen a hátrányos helyzet egyik fö jellemzője az alacsony iskolai végzettség (FEJES-JózSA 2005). A témakör kutatása során megvizsgáltam, milyen hatással van az iskolai végzettség a periférikus területeken élők elsődleges munkaerö-piaci szerepvállalására, illetve az ilyen térségekben élő hátrányos helyzetűek munkahelymegtartó-képessége függ-e a település lokális jellemzőitől, vagy a lakóhelyi szegregációtól. A kutatás további célja volt a szegénység kultúrája koncepció tesztelése a periférikus területeken élő lakosság körében, amelynek keretében az Oscar Lewis (1959) által leírt, kvalitatív eszközökre épülő kutatás egyes elemeit kvantifikálva ${ }^{1}$ vizsgáltam a témakört.

A kutatás első feladata volt megvizsgálni az iskolai végzettség hatását a periférikus területen élő hátrányos helyzetüek elsődleges munkaerő-piaci szerepvállalására. Ezen belül kérdésként merült fel, hogy az iskolai szint emelkedése pozitívan befolyásolja-e az aktív korúak elhelyezkedési lehetőségeit a nyílt munkaerőpiacon, illetve területi szinten milyen különbségek fedezhetők fel ennek összefüggéseiben.

A dolgozat második kérdésköre annak vizsgálatára irányult, hogy a periférikus területeken kialakul-e a szegénység kultúrája, és ha igen, a jelenség egyes tipikus

\footnotetext{
${ }^{1}$ Mivel az Oscar Lewis által végzett kutatások kvalitatív eszközöket használtak a szegénység kultúráját jellemző sajátosságok feltárására, ezért ezen jellemzők vizsgálatához szükséges kérdéseket a kutatásom által használt kvantitatív módszerekre kellett adaptálni. Ez természetesen nem minden attribútum esetében volt lehetséges, ezért a szegénykultúra jelenlétének kutatását három alapvető és számszerűsíthető jellemvonás (munkahelyi környezetbe való beilleszkedés; időkerethez való alkalmazkodás; a jövőtervezés időtartamának hossza) segítségével vizsgáltam. A két kutatás során alkalmazott különböző módszerek nem voltak hatással a szegénység kultúrájának koncepcionális értelmezésére.
} 
jellemvonásai - munkahelyi környezethez és időkerethez alkalmazkodás nehézsége, rövid távra tervezés - befolyásolják-e a célterületeken élőket a hosszú távú munkavállalás $^{2}$ lehetőségeinek elérésében, vagy megakadályozzák a periférikus területeken élő hátrányos helyzetüek tartós munkahelymegtartását? A szegénykultúrához kapcsolódó szocializációs normák a munkanélküliségből való kitörésre irányuló hatását lokális és területi különbségek szintjén is vizsgáltam, amely során a fókusz elsősorban a munkafeladatok elsajátítására és a munkahelyi kötelezettségek teljesítésére irányult. Ily módon betekintést nyújtok a vidéki- és a centrumhoz közeli városi periférikus területeken élő hátrányos helyzetű emberek szocializációja, életkörülményei és munkaerő-piaci nehézségei, valamint elhelyezkedési lehetőségei közötti különbségekbe.

A disszertáció harmadik feladata volt megvizsgálni a periférikus területek földrajzi és infrastrukturális jellemvonásait, amely témakör tanulmányozása során megnéztem, hogy ezen területek közösségi közlekedési lehetőségei, sajátosságai hogyan hatnak az ott élő hátrányos helyzetű emberek elsődleges munkaerő-piaci jelenlétére.

A kutatás negyedik témaköre a közfoglalkoztatás, a periférikus területeken élők elsődleges munkaerő-piaci integrációjára gyakorolt hatásainak vizsgálatára terjedt ki. Ennek keretében megnéztem, hogy a periférikus térségekben élők nyílt munkaerő-piaci integrációja hogyan változik a közmunkaprogramban való jelenlétük eredményeként. Vagyis a cél a közmunkaprogram elsődleges munkaerőpiacra gyakorolt integrációs hatásának kutatása volt, melynek folyamán megvizsgáltam, hogyan befolyásolja a közfoglalkoztatás a periférikus területeken élők munkaerő-piaci szerepvállalását. A témakört regionális viszonylatban - város és vidék relációjában -, nevezetesen a rurális, belső periférikus területen élők, és a centrumhoz kötődő magterülethez közeli városi periférikus terület lakói körében tapasztalható elsődleges és másodlagos munkaerő-piaci aktivitás vonatkozása szerint mértem.

Mindent összevetve a dolgozat átfogó célja bemutatni, milyen hátrányok érik a periférikus területeken élőket egy munkahely megszerzésében és annak megtartásában, kizárólag azért, mert területi és gazdasági szempontból leszakadó térségben élnek, illetve lakóhelyük periférikus elhelyezkedésü területen található.

${ }^{2}$ Hosszú távú munkavállalás alatt minden esetben több, mint egy évig tartó munkaviszonyt értek. 


\section{A kutatás elméleti és fogalmi háttere}

A dolgozat a periférikus területek és az ott élő hátrányos helyzetüek vizsgálatán alapul. Ezen fogalmakat a különböző kutatások gyakran eltérő értelmezés szerint használják, ezért kiemelten fontosnak tartom a kutatás szempontjából meghatározó definíciók és a kapcsolódó fogalmak pontos meghatározását. Az eredmények világos értelmezéséhez elengedhetetlen továbbá a vizsgálat elméleti hátterét nyújtó szegénység kultúrája koncepció bemutatása.

\subsection{A hátrányos helyzet jellemvonásai}

A kutatás olyan társadalmi csoportra fókuszál, amely szociális és gazdasági szempontból hátrányos körülmények között élnek. A hátrányos helyzet fogalmát a depriváció ${ }^{3}$ magyar megfelelőjeként értelmezhetjük, amely relatív lemaradást fejez ki, és a jövedelmi hátrányok mellett további jellemzőkre is vonatkozik (ANDORKA 2006). Az Európai Közösségek Bizottsága kifejezetten a munkaerö-piaci oldaláról közelíti meg a fogalmat. Eszerint egy munkavállaló akkor számít hátrányos helyzetünek, ha (1) a megelőző hat hónapban nem állt rendszeresen fizetett alkalmazásban, vagy (2) nem szerzett ISCED 3 szintü (STEEDMAN-MCINTOSH 2001) középfokú végzettséget, szakképesítést. Emellett az (3) 50 éven felüli személyek is ebbe a csoportba tartoznak, illetve (4) az egy vagy több eltartottal egyedül élő felnőtteket is ide sorolja a rendelkezés. Azok a személyek is hátrányos helyzetü munkavállalónak minősülnek, (5) akik valamely EU tagállam olyan ágazatában vagy szakmájában dolgoznak, amelyben a nemi egyensúlyhiány 25\%-kal nagyobb, mint e tagállam összes gazdasági ágazatára jellemző átlagos egyensúlyhiány és ezen alulreprezentált nemi csoportban tartoznak. Ezenfelül hátrányos helyzetű dolgozóként értékelik (6) egy EU tagállam etnikai kisebbséghez tartozó munkavállalókat, valamint azokat, (7) akinek szakmai, nyelvi képzésének vagy munkatapasztalatának megerősítésére van szüksége ahhoz, hogy javuljanak munkavállalási esélyei egy biztos munkahelyen (EUR-LEX 2008). Az EK Bizottság határozata szerint hátrányos helyzetü munkavállalók esetében ezen szempontok közül legalább egy teljesül.

A hivatalos megfogalmazás mellett a társadalomkutatók a hátrányos helyzetet általában a kedvezőtlen gazdasági tényezők fennállásával jellemzik. A hátrányos

\footnotetext{
${ }^{3}$ Depriváció: valamitől való megfosztottság. A szegénység vonatkozásában a deprivált ember egy olyan dolgot nélkülöz, amely az adott társadalom többségének hozzáférhető, vagy az adott társadalom minden tagja számára kívánatos, elérendő minimumnak tart (ANDORKA 2006).
} 
helyzetü emberek jellemzően alacsony jövedelemmel rendelkeznek, amelynek jelentős részét, vagy teljes egészét a segély, nyugdíj, vagy a másodlagos, alternatív munkaerőpiacon (például a közmunkaprogramban) szerzett bevétel, alkalmi munka utáni juttatás teszi ki. A szociálisan hátrányos helyzetü emberek kis alapterületü lakásban zsúfolt lakáskörülmények között élnek. A lakáshelyzetet többnyire olyan egészségtelen feltételek nehezítik, mint a vizes falak, az alagsorban található lakás, szuterén, vagy putri, valamint az ingatlan rossz felszereltsége, amely jellemzően a konyha, a fürdőszoba, a beltéri WC, vagy az alapvető háztartási készülékek hiányát jelenti. A hátrányos helyzet kialakulásának legfőbb oka az alacsony iskolai végzettség, a szakképzettség hiánya, vagy a munkaerő-piaci szempontból értéktelen képesítés. Mindemellett okozhatják a deviáns környezet olyan szocializációs hatásai, mint az alkoholizmus, drogfüggőség, vagy játékszenvedély. A munkanélküliség, a szociális adaptáció nehézségei, valamint az etnikai kisebbséghez való tartozás pedig növeli a hátrányos helyzet kialakulásának esélyeit (CSÉPE 2010), amelynek mértékét a területi hátrányok tovább fokozzák (ARACSIPÁl 2004, ALPEK et al. 2018).

A kutatás során a hátrányos helyzetet területi, munkaerö-piaci, szociális és szociokulturális értelemben is használom. Amellett, hogy a kutatás mintaterületein élő embereknek az Európai Közösség Bizottságának meghatározása is érvényt mutat, a témakör vizsgálata során elsősorban az életkörülményekre és az életminőségre vonatkozó deprivációt vettem alapul. A két értelmezés közös használatával a kutatási mintába került emberekről egyértelmüen elmondható, hogy mind munkaerő-piaci, mind pedig társadalmi értelmezés szerint a hátrányos helyzetben vannak.

\subsection{A periférikus területek és a szegregátumok földrajzi és társadalmi jellemzői}

A kutatás egyrészt két különbözö, mégis alapvetően hasonló tulajdonságokkal jellemezhető - centrumhoz közeli és vidéki - periférikus terület vizsgál, és hasonlít össze, emiatt lényeges a periférikus területek földrajzi, gazdasági és társadalmi tulajdonságainak bemutatása. A vizsgálatom egyik kulcsfogalma a centrum definíciója, amely a regionális tudományi kislexikon (ELTE RFT 2005) szerint földrajzi értelemben központi helyzetű térelemet jelent, vagyis a vizsgált térbeli rendszerben a többi térelemhez képest központi elhelyezkedést jelez. Infrastrukturális szempontból és a közszolgáltatások tekintetében a centrum széles körben kiépült (G. FEKETE 2011). A periféria a centrum ellentétpárja, amely a többi térelemhez képest elfoglalt peremi pozíciót mutat. A periféria sajátossága a centrumtól való függés, de a kapcsolatok hiányát és az elszigeteltséget is jelentheti (ELTE RFT 2005). A periférián a közszolgálatások 
intézményei alapvetően nem épültek ki, ezért mind az egészségügyben, mind az oktatásban és a közmüvekkel való ellátottságban jelentős hiányok tapasztalhatók, emellett rendkívül magas a szegénységi küszöb alatt élők aránya (G. FEKETE 2011). A kettő között találhatók az átmeneti, félperifériaként jellemzett térségek, amelyek vagy a centrumtól szakadnak le, vagy éppen a perifériák közül emelkednek fel. Tehát egyszerre mutatják a centrum és a periféria attribútumait is (ELTE RFT 2005). A közszolgálatások létfontosságú intézményei megtalálhatók, de egyes társadalmi csoportok számára ezek igénybevétele akadályokba ütközik (G. FEKETE 2011).

A periférikus területek értelmezéséhez MARgARITA SCHMIDT (2007) meghatározását veszem alapul, aki azon vidéki térségekben található településeket és városi településrészeket tekinti e fogalomkörbe tartozónak, amelyek elszakadtak a központi „magterületről”, és marginalizációs folyamatuk következtében az ott élöket alacsony szintü társadalmi részvétel (például elsődleges munkaerőpiacon történő munkavállalás hiánya), a szükségletek csekély mértékű kielégítése, valamint informális függőségek jellemzik. Az ilyen térségek sajátosságai az alacsony integráció, a térbeli, gazdasági és társadalmi elszigetelődés, a gyenge térségi innovációs potenciál, valamint ezen hátrányok térbeli halmozódásának egymást erősítő hatása (SCHMIDT 2007 idézi: NAGY et al. 2015A). Míg a külsö perifériák általában az országhatár mellett helyezkednek el és a fejlettség mellett földrajzi távolságban is messze esnek a regionális központoktól, addig a belsö perifériák (1. ábra) esetében a centrumtól való disztancia nem meghatározó, általában megyék és régiók szélén, vagy folyók mentén találhatók (VERES 2004).

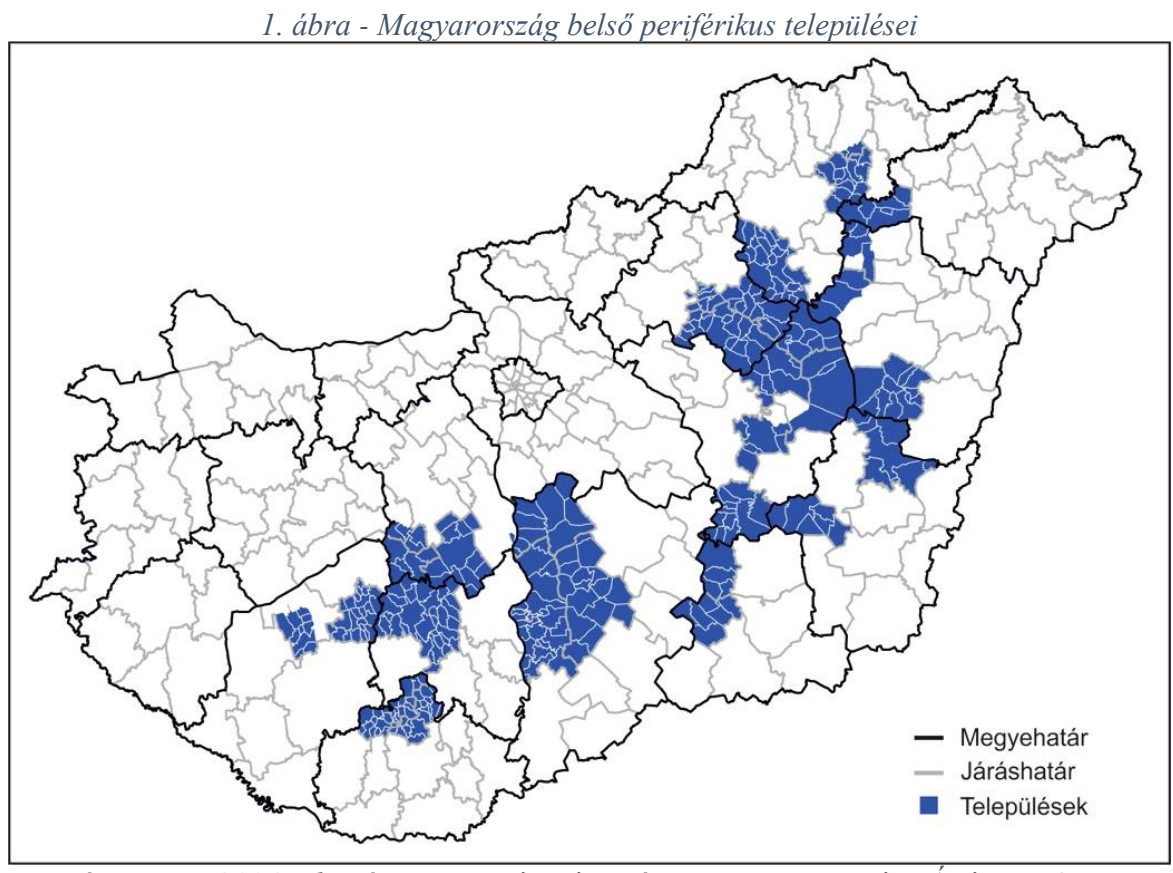

Forrás: VERES (2004) alapján DR. DUDÁS GÁBOR és ROZGONYI-HORVÁTH ÁDÁM szerkesztette 
1. táblázat - A belső és külső perifériák területi-, társadalmi- és gazdasági jellemzői

\begin{tabular}{|l|l|}
\hline Belső perifériák & Külső periféria \\
\hline Tartós gazdasági visszaesés & Kedvezőtlen természeti adottságok \\
\hline Magas munkanélküliség & Magas munkanélküliség \\
\hline Alacsony infrastrukturális ellátottság & Fejletlen infrastruktúra \\
\hline Nehéz megközelíthetőség & Közlekedési és kommunikációs elzártság \\
\hline Városhiány & $\begin{array}{l}\text { Centrumtelepülésektől való nagy távolság, } \\
\text { elszakítottság }\end{array}$ \\
\hline Szegénység, elvándorlás & $\begin{array}{l}\text { Szegénység, elvándorlás, kivándorlás, halmozottan } \\
\text { hátrányos helyzet, a „periféria perifériái” }\end{array}$ \\
\hline
\end{tabular}

Forrás: G. FEKETE et al. 2013

A területi egyenlötlenségek sajátos változata a társadalomtudományokban alkalmazott centrum-periféria fogalompár, amelynek átfogó ismertetése elsősorban IMMANUEL WALLERSTEIN (1983) nevéhez köthető, amelybe már a félperiféria kifejezést is bevonja. A modell térbeli rendszer egyenlőtlenségét fejezi ki, amely két olyan szélsőséges kategóriát - egy peremi és egy központi helyzetet - jelez, amely között aszimmetrikus függőségi kapcsolat van (ELTE RFT 2005). A centrum-periféria modell tehát egy területi egyenlőtlenséget jelenít meg, amelynek ellentétes helyzetű térelemei az egymáshoz viszonyított központi, illetve peremhelyzetet mutatják (NEMES NAGY 1996). $A$ helyzeti, vagy földrajzi centrum-periféria értelmezésben a centrum egy jelentős szerepkörrel rendelkező helyként, míg a periféria a peremhelyzetben lévő településeket jelenik meg (NEMES NAGY 1996). Földrajzi tér szerint vizsgálva a centrumhoz köthetők a társadalmi intézmények, de a meghatározás elérhetőséget, közúton és időben kifejezhető távolságot is jelenthet (LÖCSEI-SZALKAI 2008), sőt gazdasági tevékenység relatív elérhetőségével, és ennek hiányaként is értelmezhető (KEEBLE et al. 1988).

2. táblázat - A centrum-periféria egyes tértipusok szerinti viszonyulásai

\begin{tabular}{|l|l|l|}
\hline \multicolumn{1}{|c|}{ Tértípus } & \multicolumn{1}{c|}{ Centrum } & \multicolumn{1}{c|}{ Periféria } \\
\hline Földrajzi elhelyezkedés & központi helyzet & határ menti helyzet \\
\hline Hálózati elhelyezkedés & $\begin{array}{l}\text { könnyen megközelíthető } \\
\text { helyek }\end{array}$ & $\begin{array}{l}\text { nehezen megközelíthető } \\
\text { helyek }\end{array}$ \\
\hline Elérhetöség időben & gyorsan elérhető helyek & lassabban elérhető helyek \\
\hline Elérhetöség költségben & kis költséggel elérhetö helyek & $\begin{array}{l}\text { nagy költséggel elérhető } \\
\text { helyek }\end{array}$ \\
\hline
\end{tabular}

Forrás: LÖCSEI-SZALKAI 2008

A fejlettségi, vagyis gazdasági centrum-periféria értelmezés a gazdasági előrehaladást, illetve elmaradottságot veszi figyelembe (NEMES NAGY 1996), valamint a humán tőke állapotát, a társadalmi tőke minőségét, az életszínvonalat és a környezeti állapotokat tartja szem előtt (LőCSEI-SzALKAI 2008). Ez utóbbi két értelmezés alapján megkülönböztethetünk központi magot, dinamikus peremterületet, belső perifériát és 
külső perifériát (ELTE RFT 2005). A perifériák kialakulásában meghatározó szerepet játszik az adott kor gazdasági folyamataiba való bekapcsolódási képesség hiánya (G. FEKETE 2006). Az egyenlőtlen területi fejlődés eredményei a centrumokban koncentrálódnak, míg e folyamat hátrányai a termelési előnyökkel nem rendelkező perifériákon rakódnak le (SÜLI-ZAKAR 2013). A centrum országokra magas jövedelem, nagymértékü termelés, tőkekoncentráció, valamint fejlett technológiai és széleskörü innovációs lehetőségek jellemzők, míg a periférikus országok általában bérmunkát végeznek, alacsony keresetek és hozzáadott érték jellemzi, az alkalmazott technológia színvonala pedig a befektetett tőkétől függ, de saját innovációjuk mértéke minimális (CEGLÉDY 2014). A hatalmi, vagy társadalmi megközelítés a hatalmi függés és az érdekérvényesítés egyensúlytalanságára helyezi a hangsúlyt (NEMES NAGY 1996). A centrum országok társadalmaira jellemző a spontán szerveződés, és nemzetközi szinten is meghatározó befolyással rendelkeznek. Ezzel szemben a periféria államaira gyenge szakszervezetek, alacsony társadalmi szerveződés jellemző, és nemzetközi döntéshozatalban sem foglalnak el központi funkciókat (CEGLÉDY 2014). Ennek értelmében a hatalmi elit képviseli a centrumot, míg a kiszolgáltatott réteget a periféria testesíti meg (LŐCSEI-SZALKAI 2008). E viszonyrendszerben a centrum térségek gyakran kihasználják mind a félperiférikus, mint pedig a periférikus területeket (BOROS 2010).

3. táblázat - A centrum periféria viszony meghatározó elemei

\begin{tabular}{|c|c|}
\hline Centrum & \\
\hline növekedés & $\leftrightarrow$ \\
\hline irányítási, hatalmi központ & $\leftrightarrow$ \\
\hline magas fejlődési potenciál & $\leftrightarrow$ \\
\hline
\end{tabular}

\begin{tabular}{|c|}
\hline Periféria \\
\hline lemaradás \\
\hline alávetettség \\
\hline alacsony fejlődési potenciál \\
\hline
\end{tabular}

Az ilyen jellegü területi egyenlőtlenségek a különböző térségek gazdasági teljesítményeiben is megmutatkoznak, ami kihat a helyi fogyasztásra, a beruházások mértékére, de a kormányzati finanszírozások összegére is hatással van. A periférikus területeken elhelyezkedő településekből lassú és költséges a centrum települések megközelítése, amelynek okai között szerepel a központi településektől való távolság és a jellemzően fejletlen közlekedési infrastruktúrahálózat. Ezen körülmények pedig megnehezítik a periférikus térségekben élők szükségleteinek kielégítését, és a különböző szolgáltatásokhoz való hozzáférésüket (G. FEKETE et al. 2013). Az így kialakult gazdasági- és munkaerő-piaci hátrányokból adódó elszegényedés nem kizárólag anyagi jellegü problémákat eredményeznek (SIPOSNÉ NÁNDORI 2016). A periférikus területeken a legrosszabbak a gazdasági, infrastrukturális, társadalmi, szociális és foglalkoztatási 
mutatók (BARANYI 2004), és lényegesen alacsonyabb az iskolai végzettség szintje is, amelyek következtében az itt élök nagyobb arányban szorulnak szociális támogatásokra is (KIM 2011). A periférikus területek gyenge helyzeti potenciáljuk miatt gyakran a rendelkezésükre álló valós értékeiket, lehetőségeiket sem tudják megfelelően kihasználni, hiszen a terület hátrányai miatt megnövekedő költségek következtében nem térülnek meg a befektetések (G. FEKETE et al. 2013). Az ezáltal kialakult szerény munkavállalási lehetőségek eredményeként az ilyen területeken élök esetében nagyobb jelentősége van az ingázásnak (BUJDOSó 2004).

A rendszerváltást követő első telepösszeírást a Környezetvédelmi és Területfejlesztési Minisztérium végezte 1997-ben, amely során - az 1993/1997. számú kormányhatározat alapján - telepnek minősítették azt a legalább négy lakásból álló településrészt, amelynek lakásai alacsonyabb komfortfokozattal, alacsonyabb minőséggel, magasabb laksürüséggel, egészségre ártalmas elhelyezkedéssel hátrányosan különböznek a település jellegzetes lakókörnyezetétöl (OLÁH 2014). A minisztérium felmérése által használt fogalom helyett, - annak szubjektív tényezőkön is alapuló szempontjai miatt - a kutatásom során a szegregátum meghatározásához a KSH - a népszámlálások során is alkalmazott - definícióját vettem alapul. A szegregátum fogalma azokat a területek fedi le, ahol az aktív korú népességen belül a legfeljebb általános iskolai végzettséggel rendelkezők és a rendszeres munkajövedelemmel nem rendelkezők aránya magasabb mint 50\% (RÁcz 2014).

Emellett egy másik, a szegénység területi koncentrálódását alapul vevő definíció az etnikai jellegü szegregálódást is figyelembe veszi. Eszerint az elkülönülés, vagy elkülönítés az esetben formál gettót, ha (1) a terület egyértelműen elszeparálódott a település többi részétől és határai megállapíthatók. Emellett (2) a területet és az itt élőket a többségi társadalom negatív jelzőkkel megbélyegzi, stigmázza, és (3) a lakók valamilyen kényszer hatására - nem saját döntésük eredményeként - költöztek oda. Továbbá (4) a területen élők a többségi társadalomtól különböző, párhuzamos intézményrendszert használnak. E négy feltétel együttes fennállása esetén jellemezhető egy adott terület gettóként (WACQUANT 2004) ${ }^{4}$.

A szegregátumban élő társadalmi csoportok területi izolációja teljesen elzárja az ott élőket a lakosság többi rétegétől, amely miatt egy olyan szegregált területi társadalom

\footnotetext{
${ }^{4}$ Mindamellett, hogy a kutatás egyik mintaterületéül szolgáló Törteli úti szegregátumra a WACQUANT (2004) által meghatározott feltételek közül az első három teljes mértékben, míg a negyedik tulajdonság részben jellemző, a disszertációban a terület megnevezésére következetesen a hivatalos dokumentumokban és a területen végzett korábbi kutatások során is használt és elfogadott szegregátum és telep kifejezéseket, mint egymás szinonimáit használom.
} 
alakul ki (GYERGYÁK 2011), amely teljesen felveszi a periféria fent említett jegyeit. SIPTÁR DÁVID és TÉSITS RÓBERT (2014) a Baranya megyében található szegregátumok alapján négy szempont (térbeli elhelyezkedés; településközponttal való kapcsolat; méret; település típus) szerint csoportosította a telepeket. Térbeli elhelyezkedés alapján megkülönböztetnek központi, fél-központi, periférikus és külterületi szegregátumokat. A település morfológiája szerint központi-, illetve fél-központi elhelyezkedésü telepek a településen belül elfoglalt centrális lokációjuk miatt általában jól megközelíthetőek, infrastrukturális - aszfaltút, közvilágítás, stb. - szempontok szerint jól felszerelt, szolgáltatásokkal megfelelően ellátott területek. Az ilyen típusú telepeken élő marginalizálódott népesség napi kapcsolatot tart fenn a település szegregátumon kívül élő lakosságával, amely a kutatók szerint ambivalens lehetőséget jelent az egymással érintkező közösségek számára: mivel a környéken élők szocializációja közelebb áll a többségi társadalom normarendszeréhez, ezért a felzárkózás esélyét is magában hordozza a telepen élők számára. Másrészt a szegregátum lakosságának mentalitását a környezet is átveheti, így a hátrányok halmozódásához is vezethet. A települések szélén, perifériáján elhelyezkedő telepek legtöbbször valamilyen természeti képződmény völgyek, dombok - által elválasztva a település központi részétől távol helyezkednek el. Az itt élő közösségek többnyire mezőgazdasági, vagy ipari telephelyek (egykori) szálláshelyein élnek. Ezekre a szegregátumokra jellemző a hiányos infrastruktúra (aszfaltozott közút, vezetékes víz, közvilágítás), és területi elhelyezkedésük miatt a szolgáltatások csak nehezen érhetők el. A község, vagy város határán kívül, külterületén található telepek többségében korábban mezőgazdasági épületek, majorok voltak. Ezen szegregátumok lakói vannak a legnehezebb helyzetben (PÁSZTOR-PÉNZES 2018), akik egyáltalán nem tartanak fenn kapcsolatot a településsel. Ennek egyik oka a távolság, de az ilyen telepek környezetének infrastruktúrája is szerény kiépítettségü, gyakran közúttal sem rendelkeznek, a vezetékes ivóvízhálózat pedig még ritkább (SIPTÁR-TÉSITS 2014). Az itt élő marginalizált helyzetben lévő közösség a közszolgáltatásoktól elzárva éli mindennapjait, hiszen a szociális- és egészségügyi intézmények megközelítése, és a gyerekek óvodába, vagy iskolába járatása is jelentős akadályokba ütközik (PÁszTORPÉNZES 2018).

A szegregátum méretét figyelembe véve nagynak tekinthető az a telep, amelyben egynél több utca, vagy tíznél több épület szegregálódott. A szegregátum méretére hatással van a környezet leértékelődési szintje, az ingatlanok értékének csökkenése és a közterek állapota; ezek a körülmények kiválthatják a magasabb társadalmi osztályok elvándorlását egy területről, illetve a lakosságcsere folyamata során vonzzák az 
alacsonyabb presztízzsel rendelkező népességet. A szegregátum mérete befolyásolja az ott játszódó társadalmi folyamatok a környező, nem marginalizált népesség által lakott területekre való átterjedését, amely természetesen függhet az adott telep zártáságától, vagy nyitottságától, vagyis attól, hogy a szegregátumban élők mennyire állnak kapcsolatban a környezetben élő emberekkel.

A szegregátumot magába foglaló település típusa szerint megkülönböztetünk egyrészt falusi telepeket, amelyek többnyire a várostól távoli, izolált, többségében fiatal korosztály által lakott községekben alakulnak ki. Az ilyen szegregátumokban megtalálható jellemző problémák között általában első helyen szerepel a szegénység területi elkülönülése és a falu gettósodása. Ezen, földrajzilag periférikus helyzetben lévő szegénytelepek kezelése nehezebb, mint egy városhoz közeli falu telepének helyreállítása. A városi szegregátumok elsősorban a település perifériáján alakulnak ki, többnyire az indusztriális övezetekben korábban az ipari munkásoknak otthont adó területeken található épületekben, házsorokban jönnek létre. Ezen városi térségekben élők általában alacsony iskolázottsággal és sok esetben generációkon átívelő munkanélküliséggel rendelkeznek. Az itt élők szocializációs szintje alacsony, érintkezésük a városmagban élőkkel minimálisnak mondható.

A telep szempontjából meghatározó a szegregátumnak otthont adó település megyei településszerkezetben elfoglalt helyzete, amely szerint meghatározhatók centrumtérségben, pufferzónában és periférikus területen található falusi, vagy városi szegregátumok. Megfigyelhető, hogy a telepek kialakulásának esélye a centrumtól a periféria irányába fokozódik. A területi és társadalmi szegregáció kialakulásában fontos szempontot jelent az alacsony öregedési index, a cigányság magas aránya és az ingatlan komfortszintje, de kockázati tényezőként jelenik meg az ott élők iskolázottsága és foglalkoztatottsági arányuk (SIPTÁR-TÉSITS 2014).

Ezen alfejezetben a periférikus területek fogalmi magyarázatai, általános jellemzői és társadalmi folyamatai kerültek bemutatásra, amelyek segítséget nyújtanak a vizsgálati területeken mutatkozó folyamatokra. Összegzésként elmondható, hogy helyzeti értelemben vett perifériának egy adott térség földrajzi középpontjától legtávolabbi helyeket értjük, míg fejlettség tekintetében a periféria a többi térséghez képest elmaradott területet jelent. Hatalmi-társadalmi aspektus szerint periféria alatt egy központtól függő, alárendelt helyzetben lévő és gyenge érdekérvényesítő képességgel rendelkező területet értünk. Míg a belső perifériák egy terület belsejében mutatnak gazdasági-társadalmi szempontból lemaradást (FAZEKAS 2015), addig a külső perifériák földrajzi, helyzeti nézőpont szerint is a térség határain helyezkednek el (G. FEKETE et al. 2013). Miközben 
a szegregátum hivatalos meghatározásánál elsősorban az aktív korú lakosság iskolai végzettségét veszik alapul, addig a terepen végzett kutatási eredmények más szempontokat is figyelembe vesznek.

\subsection{A szegénység kultúrája}

A kutatás alapját a szegénység kultúrája ${ }^{5}$ és hatásainak vizsgálatára helyezem, amely fogalom megalkotása OSCAR LEWIS (1959) nevéhez köthető, aki mexikói családok példáján mutatta be tapasztalatait, amely szerint a szegénység és az alacsony jövedelem a nehéz életkörülmények mellett létrehoz egy olyan sajátos kultúrát is, amely teljesen eltér a középosztály értékeitől, vagy éppen az általánosan jellemző kultúrától. Ez a szegénység kultúrája (LEWIS 1966), amely egyrészt segít túlélni a mindennapokat, de egyben megakadályozza az embereket, hogy kilépjenek a szegénység körülményeiből. A szegények életmódja apáról fiúra öröklődik, amely életforma a túlélésüket szolgálja, vagyis e normarendszer nélkül nem tudnának életben maradni, viszont a szegénykultúra következtében aki egyszer szegénnyé válik, az egy bizonyos idő után vélhetően nem tud kikerülni ezen szociális helyzetből. A társadalmi körülmények és a nélkülözés pedig a családi szocializáció révén feltehetően generációkon keresztül átöröklődik (LEWIS 1965, SPÉDER 2002). Következésképp a szegénység tartósan fennmarad, és a gyermekek sem tudnak kilépni ebből a helyzetből, így egy generációs szegénység alakul ki (STENNING 2005). A nehéz körülmények miatt a szegénységben élő emberek a - többségi társadalom által deviánsnak tartott - cselekedeteiket nem normaszegésnek minősítik, hanem megélhetési módnak. A pénzközpontú társadalomból szinte teljesen kiesnek (CASTEL 1993), és a hátrányaik lehetetlenné teszik a kiemelkedést.

A szegénységnek megvan a maga szerkezete és határozott tulajdonságokkal rendelkezik. A szegénység kultúráját elsajátító személyeknek nincs tulajdontudatuk, ezért nem ragaszkodnak személyes értékekhez, nem is kötődnek hozzájuk semmilyen személyes kapcsolattal. Nem képesek felhalmozni, így a pénznek sincs igazi értéke. A szegénység kultúrája felismeri a kapcsolatot a kisebbségi lét és a rossz anyagi

\footnotetext{
${ }^{5}$ A szegénység kultúrájának elméletét egyes kutatók elismerik, mások szerint viszont nem létezik ilyen kultúra, tehát jelenléte a tudományos világban vitatott (MESSING-MOLNÁR 2010). Egyes szakemberek véleménye szerint a szegénység kultúrájának magyarázata erősíti a szegényeket hibáztató gondolkodást, hiszen álláspotjuk szerint azt sugallja, hogy nem csak a közpolitikának kell átalakulni, hanem a nélkülözésben élő embereknek is változtatni kell a hozzáállásukon (JANKY 2016 idézi: PATTERSON-FOSSE 2015). Mások értelmezése alapján a szegénység kultúrájának elmélete szerint a szegényeket a valódi kultúra hiánya jellemzi (STEWART 2002).

Korábbi kutatásaim tapasztalatai alapján személyemet az első, a szegénység kultúráját akceptáló csoportba sorolom, ezért kutatási eredményeimet ezen elmélet kereteibe helyeztem.
} 
körülmények között (SzUHAY 1999, JONES 1999, FAINSTEIN 1995, STEWART 2002). A szegénykultúra értékrendje szerint szocializálódott embereknek van közösségtudatuk, viszont mivel ez a normarendszer ellentétes a társadalom többsége által elfogadott kultúráéval (GECKOVÁ et al. 2014), ezért a szocializációs értékeik elzárják őket a többségi társadalomtól.

A szegénység kultúrája hasonló jegyeket mutat a családszerkezetben, a kapcsolatokban, az időhöz való viszonyulásban, az értékrendben és a fogyasztási szokásokban területtől, térségtől, településtípustól, országoktól és kontinensektől függetlenül. Tehát a szegénységben élő emberek a közös problémákhoz hasonló alkalmazkodási stratégiákat hoznak létre. A szegénység kultúrája egy válasz a kapitalista társadalmakban élő szegények marginális helyzetére és segíti őket annak az anómiás ${ }^{6}$ reménytelenség érzésének feldolgozásában, amelyet a többségi társadalom értékei és céljai alapján való siker elérésének hiánya jelent számukra (LEWIS 2000). A szegénység a modern társadalmakban nem csak gazdasági deprivációt, vagy szervezetlenséget jelenthet, hanem olyan pozitív előnyökkel is jár, amelyek segítik a szegényeket a mindennapi túlélésben. A szegénység kultúrájának pozitív oldalát egyrészt a jelennek élés és spontaneitás, az érzéki élvezetekre, az ösztönös érzelmekre való képesség jelenti, amely gyakran elhalványul a jövőre orientált, középosztályi emberben (LEWIS 2000).

Az egyén és a család szintjén a szegénység kultúrájában szocializálódó személyekre leginkább marginalitás, reménytelenség és a függőség tudata jellemző (LEWIS 2000). A családok esetében minimális szervezettség figyelhető meg. A gyermekkor, mint védettséget élvező életszakasz hiányát jelzi a gyerekek elhanyagolása, esetleg elhagyása, a szeretetért való versengés, a korai szexuális érdeklődés, a szabad, vagy megegyezésen alapuló informális együttélés, amely mind a férfiak, mind pedig a nők számára előnyökkel jár ${ }^{7}$. A férfiak részéről jellemző a feleség és a gyermekek gyakori elhagyása, amely miatt nö- vagy anyaközpontú családok alakulnak ki. A szegénység kultúráját elsajátító emberek hajlamosak az erőszakra, gyakori jelenség a zsúfoltságból adódó - magánélet hiánya, a gyerekek között pedig testvérféltékenység és az anyai szeretetért való versengés alakulhat ki (LEWIS 2000). Ezen családok időhöz való

\footnotetext{
${ }^{6} \mathrm{Az}$ anómia jelen értelmezésben a kulturálisan ösztönzött célok és a társadalmilag strukturált lehetőségek közötti eltérésekre (MERTON 1980) utal, amelyek az iparosodott társadalmakban általánosan elfogadott anyagi siker - társadalmi osztálytól függetlenül - munkatevékenységgel történő elérését hangsúlyozzák. Valójában a hátrányos helyzetüeknek nagyon kicsi az esélye, hogy elörébb jussanak, így őket a többségi társadalom megveti. Ilyen helyzetben nagy a kísértés, hogy akár törvényes, akár törvénytelen úton megpróbáljon kitörni (GIDDENS 2008).

${ }^{7}$ A férfiak elkerülik a hivatalos házasság és válás költségeit és jogi nehézségeit, míg a nők nem kötik magukat megbízhatatlan férfiakhoz, amely több lehetőséget, szabadságot és rugalmasságot nyújt nekik (LEWIS 2000).
} 
viszonyulása és napirendje rugalmas, amely a felnőttek számára a munka, a gyerekek esetében pedig az iskola időkeretéhez való alkalmazkodást nehezíti meg. A hátrányos helyzetűek kulturális sajátosságai tehát eleve kudarcra ítélik őket a munkahelyeken és az iskolában való megfelelő teljesítés során (FORRAY-HEGEDŰS 1985).

A lakóhelyi közösségek szintjén szegényes lakáskörülmények, komfort elektromos áram, vezetékes víz, vezetékes gáz (KósA et al. 2007), vagy fürdőszoba hiánya és zsúfoltság tapasztalható (EvANs 2004). Ebből adódóan pedig magánélet nélküli lét (MOSER 1998) és a legkisebb mértékű szabályozottság, minimális rendszerezettség (BROOKS-DUNCAN 1997) figyelhető meg, amely a többségi társadalomhoz képest marginális, elmaradott jelleget mutat. Lakóhelyük általában a falu végén, vagy városi telepen helyezkedik el, a társulásukat pedig egyfajta közösségi tudat és egymáshoz tartozás jellemzi, amely megközelítheti a faluközösségek szintjét (LEWIS 2000); a közösség tagjai jellemzően egymás között házasodnak és vállalnak gyereket (LEWIS 2000, SZUHAY 1999). A fiataloknál általános a korai szexualitás, a gyakori a partnercsere, illetve az erőszak és a feszültségek agresszív levezetése, valamint az alkoholizálás (BABINSKA et al. 2014), akár már 10 éves korban is (LEWIS 2000).

A szegénység kultúráját elsajátító szubkulturális közösségek általában olyan körülmények között jönnek létre, ahol kevés az esély a törvényes úton való boldogulásra. Ilyen csoportok a hátrányos helyzetü etnikai kisebbségek (CLOWARD-OHLIN 1960). A szegénység kultúrája által kialakult szokások, magatartás- és viselkedésmódok csak nagyon nehezen változtathatók meg, még a szegénységből való kilábalás sem vonja egyértelműen magával az értékváltást (AMBRUS 1994). Ez a szegénység kultúrájának legnagyobb ellentmondása, mivel a szegénységben nem lehet nélküle élni, viszont pontosan ez a kultúra válik a szegénységből való kilábalás legnagyobb akadályává.

Társadalmi szinten a munkanélküliség, vagy az alacsony jövedelem a tulajdon és megtakarítások hiányát eredményezi, és csökkenti a többségi társadalomban való részvétel esélyét, amelyre válaszként kialakul a naponta többszöri, kis mennyiségü élelmiszervásárlás gyakorlata (LEWIS 2000). A banki kölcsönök lehetőségének hiánya miatt a hátrányos helyzetü emberek személyes értékeiket zálogba helyezik, körükben megszokott az uzsorakamatra történő pénzfelvétel (DURST 2017), vagy szomszédok közötti informális hitelrendszer, amelynek keretében kamat nélküli kölcsönzést szerveznek összeadott pénzeikből (LEWIS 2000).

A szegénység, mint hiányállapot többszörös deprivációt jelent (FERGE et al. 2006). Nemcsak anyagi, jövedelmi, vagyoni, vagyis gazdasági tőkére jellemző javak, hanem a tudás, ismeretek, készségek és képességek, valamint oktatási lehetőségekhez való 
hozzáférés, sőt a kultúra, a szórakozás, a humán szolgáltatásokhoz és a megfelelő iskolához, vagyis a kulturális tőkéhez kapcsolódó javak (BOURDIEU 1998, GIDDENS 2008) hiányát is jelenti. Emellett jogoktól és kapcsolatoktól, valamint a társadalmi megtartó erőktől és a társadalmi tőkéhez kapcsolódó javaktól való megfosztottságot és munkaerőpiacról való kirekesztettséget is magában foglal (CASTEL 1993, GORDON et al. 2000).

A fentiek értelmében egyértelmű, hogy a Magyarországon élő hátrányos helyzetűek munkaerő-piaci integrációját - a sok esetben teljesen más érték- és normarendszer és sajátos életvitel miatt - több tényező is tovább nehezíti. Többnyire nincs jövőképük, nem tervezik az életüket, ezért egyik napról a másikra élnek, valamint kutatások eredményei szerint az iskolákban megszerezhető tudás értéke a hátrányos helyzetűek szemében csekély (HARSÁNYI-RADÓ 1997). Emellett jellemzö körükben az általános bizalmatlanság, ami miatt a gyermekek előtt is lezárul a feljebb jutás és a szociális helyzetből való kilépés lehetősége. A gyerekek 6-7 éves korukra elsajátítják e kultúra látásmódját (LEWIS 1966), alapvető értékeit és magatartástípusait, amelyet pszichológiai okok miatt esetleges anyagi körülményeik változásából adódóan, vagy feltételeik javulását követően sem lesznek képesek megváltoztatni.

A szegénység kultúrájának fogalma tehát egy olyan életmódot jelent, amely adott történelmi és társadalmi körülmények között jellemzi a szegényeket. A szubkultúra létrehozza azokat a gyakorlatokat ${ }^{8}$, amelyek következtében fenn tud maradni. Ehhez leginkább a benne szocializálódó gyerekek világnézete, jövőképe és személyisége járul hozzá, ezért a gazdasági feltételek javulása nem elegendő ezek megváltoztatásához, megszüntetéséhez. A szegénységet könnyebb felszámolni, mint a szegénység kultúráját, amely csak több generáción átívelő folyamatként képzelhető el (LEWIS 2000). Ezen kultúra jegyei alapján szocializálódó emberek ismerik a középosztály értékeit, de nem ezek szerint élnek. Nem vesznek részt a társadalom szervezésében és annak intézményeiben ${ }^{9}$, nem illeszkednek be a többségi társadalomba, jellemző a gazdasági eszközök hiánya, a szegregáció, a közöny és a helyi problémamegoldások kialakulása (LEWIS 2000).

\footnotetext{
${ }^{8}$ A létért és a túlélésért való folyamatos küzdelem, munkanélküliség, képesítést, vagy végzettséget nem igénylő alkalmi munkák, gyermekmunka, megtakarítások teljes hiánya, élelmiszer-hiány, pénzkölcsönzés uzsorakamatra, zsúfolt otthon, alkoholizmus, gyakori erőszak, agresszív gyermeknevelés, asszonyok verése, korai nemi élet, ideiglenes élettársi viszonyok, tervek nélküli élet (ToWNSEND 1979).

${ }^{9}$ Kivétel lehet a vallási intézmények, amelyek életben tartják az embereket a szegénység állapotában, viszont ennek inkább megőrző, mint megszüntető hatása van (LEWIS 2000).
} 
2.4. Magyarország periférikus területein és szegregátumaiban élők szegénység kultúrájához kapcsolódó szocializációs értékrendje

A szegénység kultúrája hasonló jellemvonásokat, alkalmazkodási technikákat és túlélési stratégiákat teremt a különböző területeken és országokban a szegénységben élő családok és közösségek körében (Lewis 2000). Mivel az elszegényedés és a szegregáció hatalmas méretủ Magyarország vidéki területein (KIss 2001, Koós 2015B), ezek együttes térbeli hatása (JANEVIC et al. 2010, KósA et al. 2007, LADÁNYI-SZELÉNYI 2001) a többségi társadalom értékrendjétől egészen eltérő szabályok, normák és gyakorlatok kialakulását eredményezi (VIRÁG 2009). A hátrányos helyzetủ kistérségekben található alacsony lélekszámú települések a leginkább érintettek a munkahelyek hiányával, ezért az itt élő emberek többsége szociális segélyekböl és különböző transzferjövedelmekböl ${ }^{10}$ (VÁRADI 2014, BALCSÓK 2000) tartják fenn magukat és családjukat, amely csak a szegénységi küszöb alatti éleszínvonalat enged meg számunkra. Ezért a túlélés egyik általánosan alkalmazott stratégiája az igények csökkentése és az életszínvonal jövedelemhez való igazítása (BALCSÓK 2000).

Magyarország 823 településén és 10 fővárosi kerületében ${ }^{11}$, de többnyire falvak határában, vagy városi külterületeken található 1633 szegregált telepen körülbelül 300 ezer ember él (DOMONKOS-HERCZEG 2010), akiknek világát meghatározó szubkultúrát a sorsközösség vállalása jellemzi (SOLT 2010). A szegénytelepeken élő kisközösségek szubkultúrája a többségi társadalom életformájától teljesen eltérő életmódot mutat, amely a társadalom által elfogadott normák elleni tevékenységekre ösztönzi deviáns viselkedésre hajlamos tagjait (SUTHERLAND et al. 1984). Ezért a telepszerü környezetben élők mindennapjai a társadalom többségének értékrendjétől egészen különböző szabályokon és viszonyítási pontokon alapulnak. A szegregátumokban élők helyzetét a pozitív jövőkép hiánya, a diszkrimináció és a társadalom majoritásának elzárkózása konzerválja (SOLT 2010). Ilyen szubkulturális közösségi életmód során semmilyen más normakínálat nem tud érvényesülni, ha azok a felkínált értékek nem jelennek meg tartósan, amelyek ki tudnák egyenlíteni a szegénység kultúrájának értékrendszerét. A személyiségre pedig leginkább a család szocializációs szerepe van hatással (MARGITICSPAUWLIK 2006), amely általában természetes és spontán módon befolyásolja a gyerekek társadalmi érvényesülésének esélyét, hiszen a gyerekek normái és viselkedésmódozatai

\footnotetext{
${ }^{10} \mathrm{Az}$ eredeti jövedelemelosztás során szerzett jövedelem egy részét a közhatalom elvonja és részben másoknak, vagy ugyanazok számára, más jogcímen odaadja. E másodlagos elosztás során szerzett jövedelmeket nevezzük transzferjövedelmeknek (ZOMBORI 1997).

${ }_{11}$ Eszerint a magyarországi települések egynegyedében $(26,2 \%)$ tapasztalható lakóhelyi szegregáció (DOMONKOS-HERCZEG 2010).
} 
a családi kisközösségek szociális és kulturális jellegzetességeinek eredményeként alakulnak ki. Viszont a hátrányos helyzetủ családok sajátos szerkezete és jellemzően magas létszáma miatt a gyerekeket az átlagosnál több referenciaszemély veszi körül, így a követendő mintát nem feltétlenül a szülők jelentik számukra (FORRAY-HEGEDŰS 2003).

A szegregált környezetben élök körében kialakult jövedelmi és fogyasztási szegénység következtében keletkező sajátos szükségletkielégítési stratégiák sok esetben vagyon elleni cselekményekkel párosulnak (SOLT 2010). Emellett a megélhetési stratégia részét képezi a több családból álló háztartások müködtetése, vagy a villanyáram vezetéken történő átadása is. Ugyanakkor az uzsorakamatra felvett kölcsön, a bolti hitel és a közös részletre vásárlás, valamint az egymásnak történő kezességvállalás szintén a szegregátumban élő emberek mindennapjainak átvészelését szolgálják. A telepi közösségek egyik alapelve a megszerzett javak közös felhasználása. Tehát akinek éppen van valamije, annak kötelessége megosztania másokkal, hiszen máskülönben a közösség részéről kizárásra kerül. Tehát a szegergátumokban élő nukleáris családok az egymáshoz kapcsolódó szálakon keresztül egy közös rendszert alkotnak, amelynek tagjai egymás erőforrásait élik fel. Így a telepeken kialakult mélyszegénységből való kiutat a közösség alkotta szolidaritási háló kötelezettségei is akadályozzák (FARKAS 2014).

A telepeken élők körében ezen értékek elsajátítása a szocializáció részét képezi, amely megélhetési stratégia az objektív életkörülmények reprodukciója által nemzedékeken át öröklődik (WARZYWODA-KRISZYNSKA 2000). Tehát a periférikus területeken élők körében kialakult szubkultúra fennmaradásában a szocializáció során történő átörökítésnek kiemelkedő szerepe van. A szegregátumokban élő hátrányos helyzetű családok integrációs esélye a népesség majoritásába - leginkább a szegénység által alakított -, a többségi társadalom értékrendjétől teljesen eltérő normái miatt igen csekélynek mondható. A telepen élő családok társadalomhoz való viszonyát elsősorban a felnőttek inaktivitása és az ebből adódó szegénység alakítja, a szülők ezen tényezők által formálódott látásmódja hozzájárul a következő generáció devianciájának kialakulásához (RÁCZ-LÉNÁRD 2003). Ennek következtében a szegénytelepeken felnövekvő fiatal korosztály nem jelenik meg a munkaerőpiacon potenciális munkaerőként, amelynek oka a szubkultúra sajátos szocializációja mellett az ezzel összefüggésben álló alacsony iskolai végzettség. A szegregátumokban tapasztalható életfeltételek (BÉNYI-KÖSZEGI 2003) és szociokulturális körülmények hatására az ilyen környezetben nevelkedett gyerekek nehezen illeszkednek be a közoktatási rendszerbe, ez pedig kihatással van az iskolai teljesítményükre. Hiszen a családi háttér és a tanuláshoz szükséges feltételek rendelkezésre állása, vagy ezek hiánya jelentősen meghatározza a 
tanulás sikerességét (KATANICS et al. 2006). E családok körében jellemzően nem elérhetőek a gyerekek fejlődéséhez szükséges anyagi feltételek, ezért e fiatalok fizikai, értelmi és érzelmi fejlődése jelentős hiányokat szenved. Azonban különböző kutatási eredmények (GúTI 2001, FEJES-SZÜCS 2009, KENDE 2004, FORRAY 2013) igazolják, hogy a szociokulturális szempontból hátrányos helyzetü diákok (CSONGOR 1993) teljesítményére és szocializációjára az integrált oktatási közeg előnyösen hat (SZMJVÖ 2014A). A napi megélhetési kényszerek természetesen kevésbé befolyásolják azon fiatalok terveit, akiknek még nincs gyermekük, mint azokét, akik fiatal szülőkké váltak. A marginalizált társadalmi csoportokban elfogadott korai gyermekvállalás (DURST 2001, 2006) sokszor elsőbbséget élvez a továbbtanulással szemben (BÉKI 2013), a tanulmányok megszakítása viszont tartósítja a családok helyzetét, hiszen az ebből következő alacsony iskolai végzettség jelentősen csökkenti a munkaerőpiacon való elhelyezkedés esélyét (PONGRÁCZ-S. MOLNÁR 1994). A hátrányos helyzetü területeken tapasztalható perspektívák hiánya miatt a fiatal diákokat a tanárok, a barátok és még a szülök többsége is arra bátorítja, hogy költözzenek el a térségböl (TíMÁR-VELKEY 2016).

A fentieket összegezve elmondható, hogy Magyarország vidéki térségeiben, falusiés városi szegregátumaiban is kialakul a szegénység kultúrájára jellemző, a társadalom által közvetített normáktól teljesen különböző értékrendszer, amely az ebben szocializálódó közösségeket elszigeteli a többségi társadalomtól. Ennélfogva a periférikus területeken élő hátrányos helyzetü gyerekek - más hátráltató tényezők hatásainak is köszönhetően - nemigen tudnak alkalmazkodni a közoktatási rendszer elvárásaihoz, amelynek következményeként többnyire csak alacsony iskolai végzettséget szereznek. Ebből adódóan pedig nem lesz esélyük elhelyezkedni az elsődleges munkaeröpiacon.

2.5. Periférikus területek és az ott élők társadalmi helyzetének kialakulása

A szocialista gazdasági rendszer hangsúlyainak és az 1960-as és 1970-es évek településfejlesztési programjainak köszönhetően a hazai települések nagysága és fejlettsége között (ALPEK-TÉSITS 2017C) szoros összefüggés alakult ki, amely miatt a kistelepüléseken a hátrányos helyzetü lakosság jelentősen felülreprezentált (VIRÁG 2009). Ez pedig a szegregáció egyértelmü jeleként értelmezhető (FÓNAI-FILEPNÉ NAGY 2001). A rendszerváltás után a területi, társadalmi és gazdasági egyenlőtlenségek felerősödtek (NEMES NAGY 2009, OBÁDOVICS et al. 2012), a szegénység a periférikus területeken lévő aprófalvakban koncentrálódott (BAJMÓCY-ILCSIKNÉ MAKRA 2018), így 
a települések nagysága és a településen élők státusa között is erős kapcsolat formálódott ki (LADÁNYI-SZELÉNYI 2005). Ennek következtében az országos tendenciával ellentétes demográfiai (BAJMÓCY-BOROS 2005) és társadalmi folyamatok jellemzik ezeket a településeket. Ilyen tendencia a lakónépesség számának emelkedése, és a munkaerőpiactól való eltávolodás fokozódása. A periférikus kistérségekben kialakult etnikai és szociális hátrányok pedig tovább erősítik ezt a folyamatot, ezzel csaknem lehetetlenné téve a kitörést (VIRÁG 2009, SZIRMAI 2015). A helyben való megélhetés esélyének rendkívül alacsony szintje mellett ezek a kistelepülések és térségek jellemzően távol esnek a nagyobb foglalkoztatóktól. Mindemellett ezen munkahelyek megközelítése több szempontból is problémás: a tömegközlekedési lehetőségek szervezettsége többnyire alacsony színvonalú (KISS 2001) és drága, amely negatívan befolyásolja a munkaadók foglalkoztatási kedvét, hiszen ezen költségek túlnyomó része ${ }^{12}$ a közigazgatási határon kívülről bejárók esetében őket terheli. Ezek a körülmények viszont tovább erősítik az aprófalvak izolációját (LADÁNYI-SZELÉNYI 2005). Emellett, mivel egy terület térbeli fejlettségét a munkaerő-piaci helyzet mellett az ingatlanpiaci feltételek is meghatározzák, a periférikus helyzetben lévő településeken található ingatlanok rendszerváltást követő folyamatos értékcsökkenése (VALUCH 2014), és az ingatlanárak települési és területi különbségei (KovÁcs et al. 2005) nem adnak lehetőséget az itt élők számára, hogy elköltözéssel javítsanak helyzetükön (VIRÁG 2006, 2010, TóTH 2014). Így a periférikus területeken élők körében tapasztalható magas arányú költözési szándékhoz (HORVÁTH 2016) csak alacsony arányban köthető megvalósuló településváltás. Tehát a periférikus térségekben kialakult feltételek nem teszik lehetővé, hogy a leghátrányosabb helyzetü területeken élők a munkaerő-piaci szempontból prosperálóbb területek irányába költözzenek (BASS 2010). E területeken élö helyi társadalmak nem rendelkeznek olyan tudás-, pénz-, vagy kapcsolati tőkével (BOURDIEU 1998), amely elősegítené a helyzetükből való kitörést, akár migrációval, akár vállalkozóvá válással, akár helyi összefogással. Ez pedig tovább gyengíti a periférikus térségek demográfiai, társadalmi és gazdasági helyzetét (TímÁR et al. 2015).

A rendszerváltás után a gazdasági szerkezetváltást követő financiális visszaesés a foglalkoztatás és az ingázás jelentős csökkenésével járt együtt. Ez utóbbiban szerepet játszott az - alacsony iskolázottságú, munkaerőpiacról többnyire kiszorult, csekély jövedelemmel rendelkező rétegek számára már megfizethetetlen - utazási költségek nagymértékü emelkedése (KERTESI 2000B). A további negatív következményeként

12 39/2010. (II. 26.) Kormányrendelet alapján 86\%, de legfeljebb 30.000 Ft 
kialakult regionális különbségek (PÉNZES 2010, KovÁCS et al. 2015B, NAGY 2004, TÉSITS 2007A) legfontosabb meghatározója pedig az adott térség iskolázottsági szintje lett (ÁBRAHÁM-KERTESI 1996). 1990-től kezdődően az új körülmények hatására a vidék periferizálódási folyamata felgyorsult (SÜLI-ZAKAR 2016), az évtized közepére pedig az ipari tengely felbomlásával - Magyarország térszerkezete átalakult, és az ország nagyobb részén külső- és belső perifériák alakultak ki (SÜLI-ZAKAR-LENKEY 2014). Hátrányos helyzetű települések területi koncentrációi leginkább Északkelet-, illetve Délnyugat-Magyarországon (KULCSÁR et al. 2011), a határmenti külső perifériákon (PÉNZES et al. 2018B), illetve a belső perifériákon alakultak ki (PÉNZES et al. 2018A, KISSSZALKAi 2018, PÁSZTOR-PÉNZES 2012, TÁTRAi 2014, KoÓs 2015B). Ezen területekre jellemző az alacsony vállalkozási szándék, a külföldi és belföldi aktív tőke hiánya és a lakosságszámhoz viszonyított kevés munkalehetőség (CSATÁRI 2001), az ingázás pedig jövedelmi szempontból nem, vagy csak nehezen vállalható (KERTESI 2000B). E körülmények pedig az ilyen sajátosságokkal rendelkező térségek településeinek végleges periferizálódásához vezetnek (KovÁCS et al. 2015A). Ezen területek korábbi lakosságának tehetősebb rétege a magasabb szintü megélhetési és munkalehetőségek miatt a közeli nagyvárosokba, vagy Budapestre költözött, akik helyére szelektív migrációval (PÉNZES et al. 2018A) a perifériák aprófalvas vidékeire és a városok külterületeire (BAJMÓCY et al. 2018) jelentős arányú hátrányos helyzetü (VASÁRUS 2016), leginkább roma lakosság telepedett le. Így a cigányság foglalkoztatási esélyeit az alacsony iskolázottságuk (SÜLI-ZAKAR 2013, BALCSÓK 2000) és a munkaerö-piaci diszkrimináció mellett a területi hátrány is csökkentette (KOCSIS-KovÁCS 1999, KERTESI 2000A, ÁBRAHÁM-KERTESI 1996, NAGY et al. 2015A). A folyamat eredményeként szegregálódott falvak (PÉNZES et al. 2018A) és városi szegregátumok, szegénytelepek jöttek létre (NAGY 2012). A szegregáltabb lakókörnyezet viszont csökkenti a munkába állás esélyeit (BABUSIK 2007, KEMÉNY-JANKY 2003), ugyanakkor a területi elkülönülést kiváltó okok csak hosszútávú, konzekvens társadalom és gazdaságpolitikai lépésekkel szüntethetök meg (VERESNÉ SOMOSI et al. 2016).

Tehát összegezve elmondható, hogy a rendszerváltás előtt a falvak gazdasága a termelőszövetkezetek által a szocialista tömegtermelésre lett alakítva, amely a szocializmus összeomlásával és a keleti piacok elvesztésével (SÜLI-ZAKAR 1997) véget ért. A rendszerváltást követően a magyar agrártermelés válsága miatt a belső perifériák falvaiban az átlagot meghaladó mértékben csökkentek a munkalehetőségek (SZABÓ 2005), majd a '90-es évektől kezdődően széleskörü jelenséggé vált a belső periférikus területek megjelenése (PÉNZES 2010). A gazdasági és politikai függőség miatt a térbeli 
periferizáció és a társadalmi marginalizáció (SIPTÁR et al. 2016) koncentráltan jelenik meg ezeken a vidéki területeken (NAGY et al. 2015A). Mivel ezen térségekbe nem érkeznek befektetők (NAGY et al. 2015A, BARANYI 1993) és ipari létesítmények sem települnek le, társadalmi osztálytól, nemtől és etnikumtól függetlenül a periférikus területek arra kényszerítenék az ott élőket, hogy elhagyják lakóhelyüket. Az egyetlen tőkéjükként szolgáló házaikat viszont még egy városi lakás töredékéért sem tudják eladni, emiatt pedig kénytelenek a településen maradni (TíMÁR-VELKEY 2016). A marginalizáció egyik mozgatórugója pedig az állam egyre csökkenő szerepe az egyenlőtlenségek mérséklésében (BERNDT-COLINI 2013 idézi: TíMÁR 2015, WACQUANT 2011). Ezért a jövőbeli folyamatokat tekintve a hasonló nehézségekkel küzdő területek további külső-belső periferizálódása és gettósodása várható (Koós 2015A). Így a periférikus térségekben élők tovább örökítik a szegregációval összefüggő problémákat, hiszen a lakóhelyi elzártság és a háztartások szociális helyzete lehetetlenné teszi a következő generáció számára a megfelelő iskoláztatást és a piacképes tudás megszerzését (BARANYI et al. 2003).

\subsection{A periférikus területek munkaerö-piaci helyzete és nehézségei}

A szocializációs különbségek mellett a területi hátrányok is megnehezítik a hátrányos helyzetü emberek társadalmi felzárkózását, munkaerő-piaci elhelyezkedését. A települések mérete és elhelyezkedése (PAPP et al. 2017), valamint a térség emberi tőke állománya (ÁBRAHÁM-KERTESI 1996) jelentős összefüggést mutat a foglalkoztatás, a munkanélküliség (BAJMÓCY-BALOGH 2002A) és a szegénység mutatóival. Ezt jelzi, hogy Budapesttől és az ingázókat is nagy számban alkalmazó központoktól az aprófalvak iránya felé fokozatosan csökken a munkaképes korúak foglalkoztatottsága, amellyel párhuzamosan pedig növekszik a munkanélküliség mutatója (SZILÁGYI-GERSE 2015). Ennek eredményeként a szegénység az alacsony iskolázottságú lakossággal rendelkező kistelepüléseken koncentrálódott (BALCSÓK 2000).

Az egyenlőtlenségek vizsgálata során könnyen észrevehetők a területi- és települési különbségek a megélhetési lehetőségek és a jövedelem mértéke, valamint a szolgáltatásokhoz való hozzáférés terén is (CSOBA et al. 2008, VIRÁG 2009, VELKEY 2014C). Következésképpen a periférikus helyzet és a fejletlenség elsősorban az aprófalvas területeket jellemzi (BAJMÓCY-MAKRA 2005), ahol a mélyszegénység erőteljes hatással van az ott élők egészségi állapotára (FÓNAI et al. 2007, SÜLI-ZAKAR 2013, PÁL 2017), amely tovább konzerválja a hátrányos helyzetet (PÁL 2013). 
BASS LÁSZLÓ (2010) kutatási eredményei alapján a szegénységi ráta a kistelepüléseken a legnagyobb és a közfoglalkoztatás mértéke is itt a legmagasabb (26\%). Vizsgálatai szerint Magyarország összlakosságának 7,6\%-a él 1000 főnél kisebb létszámú településen, viszont a leghátrányosabb helyzetű kistérségekben élő emberek 20\%-a lakik kistelepülésen, aprófalvakban. Az LHH kistérségekben élő regisztrált munkanélküliek 60,5\%-a több, mint egy éve, 47\%-uk több, mint 2 éve nem talált állást, 15\%-uknak pedig soha nem volt még munkája. A hátrányos helyzetü kistérségekben található 1-2000 fös településeken élő aktív korúak 10,4\%-a több, mint 3 éve munkanélküli, valamint az itt élők csaknem fele $(46,6 \%)$ relatív szegénységben él, tehát a mediánjövedelem $60 \%$-ánál kevesebb $\left(\mathrm{OECD} 1^{13}\right)$ jövedelemből tartja fenn családját. A szegénység mértéke pedig a családok gyermekeinek számával arányosan növekszik. Az LHH kistérségekben élő gyermekes családok foglalkoztatási mutatói rendkívül alacsonyak (ALPEK-TÉSITS 2017A), hiszen az aktív korúak csak egyharmada számít keresőnek, ezért a munkanélküliség mértéke jelentősen meghaladja az országos átlagot (BASS 2010).

Hazánkban a rendszerváltást követő gazdasági struktúraváltás eredményeként (SIPTÁR et al. 2016) számottevően és hirtelen esett vissza az iskolázatlan munkaerő iránti kereslet (KERTESI-KÖLLŐ 2001), hiszen nagymértékben szüntek meg hátrányos helyzetü munkavállalókat tömegesen alkalmazó, képzettség nélkül is betölthető, főként betanított munkára épülő munkahelyek. A kedvezőtlen területi adottságokkal és közlekedési infrastruktúrával jellemezhető településeken élő, alacsony iskolai végzettséggel rendelkező emberek helyzete ezért kiváltképp nehéznek mondható (KERTESI 2000B). A 2008-as gazdasági válság Magyarországon leginkább az iparosodott térségekben érződött és különösen a hátrányos helyzetű kistérségekben fejtette ki hatását (NAGY et al. 2016). Tehát éppen ott csökkent tovább a foglalkoztatottság, ahol a legnagyobb volt a munkanélküliség. A válságra adott válaszként egyrészt több önkormányzat is közmunkaprogram indításába kezdett (BOROS-PÁL 2011, ALPEK-TÉSITS 2014A), másrészt ezen térségekben - ahol a népesség általában alacsonyan iskolázott, és az emberek többnyire kevésbé megbecsült munkákat végeznek - a válság hatására növekedni kezdett az atipikus foglalkoztatási formák (G. FEKETE 2016) alkalmazása. Ez viszont csak átmeneti megoldást nyújt a jövedelemnélküliséggel járó problémákra,

\footnotetext{
${ }^{13}$ Az OECD1-skála mérése szerint a háztartásban élő háztartásfőhöz 1 fogyasztási egységet, míg a további 15 év feletti háztartástagok 0,7 egységet, a 16 év alatti gyerekek pedig 0,5 ekvivalencia értéket képviselnek (GÁBOS-Szívós 2016) A skála számításának képlete: $\mathrm{E}=1+0,7 \cdot($ felnőttek száma - 1) + 0,5 • gyermekek száma.
} 
hiszen a munkaadók általában éppen ezeket a munkavállalókat bocsátják el először a termelés csökkenésekor, mivel a részmunkaidőben, vagy határozott idejü szerződéssel dolgozó, esetleg munkaerő-kölcsönző cégen keresztül alkalmazott emberektől tudnak megválni a legkönnyebben. A fejletlen településekről a nagyvárosokba való ingázás (PÁLÓCZI 2016, ALPEK et al. 2016) az utazási költségtérítésen ${ }^{14}$ keresztül pedig többletkiadást jelent a munkáltatók számára. Az ilyen jellegű települési és munkaerőpiaci hátrányokkal küzdő emberekből lesznek a legmagasabb arányban az ún. kényszervállalkozók (LEVELEKI 2012).

Tehát a városi munkaadók a ritka és költséges közösségi közlekedés miatt nem szeretnek a munkahelytől távolabb lévő községekben élő munkavállalókat alkalmazni (TÉSITS-ALPEK 2013, BASS 2010), ez pedig komoly szerepet játszott a falusi munkanélküliség magas szintjének kialakulásában, amely elsősorban a válságövezetekben jelent számottevő problémát (KERTESI 2000B). Így a közlekedési nehézségek tovább konzerválják a földrajzi szegregáltságot, amely hozzájárul mind a régiókon belüli, mind pedig a régiók közötti egyenlőtlenségek fennmaradásához (KERTESI-KÖLLÖ 1998, TÉSITS-KERESZTES 2008). Hiszen a periférikus helyzetben lévő kistérségekben található településeken a korábban - a többségében képzetlen munkaerőt alkalmazó munkalehetőséget biztosító - gyárak, bányák (PÉNZES et al. 2014, NAGY 2006), termelőszövetkezetek megszüntek (KoVÁCS 2017), helyi vállalkozások viszont nem indultak, a multinacionális vállalatok pedig inkább olyan területekre települnek (KERTESI 2000B), ahol az infrastruktúra már kiépült, valamint olcsó és/vagy képzett munkaerőt tudnak alkalmazni. A hátrányos helyzetü településeken élők pedig jellemzően a hazai átlagnál jóval alacsonyabb iskolai végzettséggel rendelkeznek (TímÁr et al. 2015). Tehát a vidékiséget meghatározó egyes ismertetőjegyek (G. FEKETE 2015) kedvezőtlenül hatnak a munkahelyek létesítésére. Ilyen jellemzők közé tartozik a vállalkozások és szükséges tulajdoni háttér hiánya (G. FEKETE 2014), a limitáltan meglévő képzett humán erőforrás és anyagi- és szellemi lehetőségek. Emellett a centrumoktól való távolságból adódó földrajzi-, társadalmi-, és gazdasági perifériaproblémák, valamint az ezek leküzdéséhez szükséges közlekedési- és kommunikációs infrastruktúra helyzete, és az érdekérvényesítő képesség hiánya is hátráltatja a befektetéseket (G. FEKETE 2015). Ezért nem meglepő, hogy a társadalmi státusz a városoktól való távolsággal arányosan mérséklődik (SYKORA 2009), az esélyek pedig a település méretének csökkenésével arányosan redukálódnak.

14 39/2010. (II. 26.) Kormányrendelet alapján 86\%, de legfeljebb 30.000 Ft. 
Noha az elhelyezkedés esélyeit a demográfiai tényezőknél is magasabb mértékben határozza meg az iskolai végzettség, a hátrányos helyzetü településeken a nők és a 30 évnél fiatalabbak foglalkoztatottsága a helyi átlagos szintnél is alacsonyabb, a romák esetében pedig csak elenyészőnek mondható (TÉSITS-ALPEK 2017, BASS 2010, BALCSÓK 2000). A periférikus területeken élők és a hátrányos helyzetű csoportok foglalkoztatásában elsősorban az élőmunka-igényes szektorok vállalnak jelentős szerepet (MOLNÁR 2017), és bár az ipari ágazat bővülése növeli a foglalkoztatást (SIPOSNÉ NÁNDORI 2016), az indusztriális üzemek sem minden esetben ajánlanak egész éves lehetőségeket. Ezért a periférikus térségekben élők az alacsony iskolázottság miatt legfőként a mezőgazdaságban és az építőiparban találnak kínálkozó munkalehetőségeket. Viszont a településhierarchia alacsonyabb fokain sokszor már csak az állam által müködtetett másodlagos munkaerő-piaci pozíciók válnak elérhetővé a közfoglalkoztatásban (KovÁCs et al. 2015A). Így nem meglepő, hogy a leghátrányosabb helyzetü területeken megfigyelhető 21\%-os munkanélküliségi ráta (BASS 2010) több, mint kétszerese az adott időszakban mért 9,9\%-os országos átlagnak (KSH 2009).

Világosan látható, hogy a települések lakosságszámának csökkenésével és egy megyei jogú városhoz való távolságával párhuzamosan csökken az iskolázottság szintje (BECSEI 2006) és növekszik a deprivációs index értéke (KoÓs 2015B), amelynek értelmében az ilyen területeken élők lakóhelyük mérete és elhelyezkedése miatt hátrányt szenvednek az ország többi lakóival szemben (BoROS-NAGY 2013). A munkaeröpiacra jutás fő akadályozó tényezői között szerepel a regionálisan egyenlőtlen munkahely kínálat, a rugalmatlan munkaerőpiac, és az álláskeresők - elsősorban jövedelmi okokra visszavezethető - alacsony mobilitási képessége. Emellett az alacsony iskolai végzettség, és a tartós munkanélküliségből (ALPEK-TÉSITS 2017B) adódó motivációs problémák, de a közlekedési nehézségek (ALPEK-TÉSITS 2014B) és a gyermekfelügyeleti (SZABÓ 2005), illetve a gondozási, ápolási szolgáltatások hiánya is nehezíti a periférikus területeken élők elhelyezkedését (KIM 2011).

\subsection{A hátrányos helyzetben élők lokális viszonyai}

A magyarországi rendszerváltozáshoz szorosan kapcsolódik az 1990-ben létrehozott önkormányzati törvény ${ }^{15}$, amelynek eredményeként ugyan megszünt a települések megyei alárendeltsége és lehetőséget biztosít a települések önálló érdekérvényesítésére, de a közfeladatok finanszírozását és a szociális feladatok ellátását

15 1990. évi LXV. törvény 
is helyi szintre helyezte mind a segélyek kifizetése, mind pedig a szolgáltatások megszervezése terén. A szociális szolgáltatások önkormányzati szintre helyezése viszont kevésbé hatékony módon valósult meg: a törvény bizonyos szolgáltatások megszervezését lakosságszámhoz köti, így nem reflektál a helyi problémákra és a település teljesítőképességére. VIRÁG TÜNDE kutatásai (2009) szerint az ilyen jellemzőkkel rendelkező területeken található aprófalvak és kistelepülések hiányzó szolgáltatásait a polgármesterek, vagy a hivatali alkalmazottak próbálják pótolni, akiknek egyszerre kell a támogató rendszereket és a szociális ellátás területén meglévő hiányosságokat megoldani. Az alacsony lélekszámú falvakban a szociális problémák halmozottan vannak jelen, a szegénység pedig az adott közösség és az egyének saját problémájává vált.

A periférikus területen található önkormányzatok szociálpolitikájára (FÓNAI 2016) jellemző, hogy a szociális feladatok ellátására érkező normatívát más forrásokkal együtt, a helyi lehetőségeknek megfelelően használják. Ez azért is fontos, mert az 1999-ben módosított szociális törvény ${ }^{16}$ az aktív korúak foglalkoztatási helyzetének megoldását is önkormányzati szintre ${ }^{17}$ helyezte (VIRÁG 2009). Ezért e településeken élő falubeliek számára az önkormányzat vezetésével fenntartott jó viszony alapvetően szükséges a mindennapi boldoguláshoz, hiszen a segélyek és az alternatív munkaerőpiacon végezhető munkák mellett az önkormányzat által koordinált közfoglalkoztatás (SÜLI-ZAKAR 2016) nyújthat számukra bevételt. Mivel a településvezetők többsége egyfajta nevelőeszközként alkalmazza a közmunkaprogramba való bekerülés lehetőségét (PÁLÓCZI-KozMa 2016, DuRst 2017), ezért a periférikus területeken élő emberek önkormányzattal való kapcsolatának minősége kiemelkedően fontos (NAGY et al. 2015B), hiszen megélhetésük alapját a közmunkához való hozzáférés jelenti. Ennek következtében a helyi vezetéssel való viszony minősége jelentősen meghatározza (MESSING-MoLNÁR 2010) a hátrányos helyzetủek életszínvonalát, emiatt természetesen igyekeznek jó kapcsolatot ápolni a polgármesterrel és a képviselőtestülettel (SOLT 2010).

\subsection{A periférikus területek és az alternatív munkaerőpiac kapcsolata}

A periférikus területeken a hosszú távú munkavállalásra nagyon kevés lehetőség mutatkozik, az állandó és bejelentett munka leginkább a képzetlenek, a nők és a fiatalok számára tünik elérhetetlennek. Mivel a hátrányos helyzetü családok szociális segélyekből

\footnotetext{
16 1999. évi CXXIII. törvény

17 A 2015-ben átdolgozott segélyezési rendszer az FHT (foglalkoztatást helyettesítő támogatás) megállapítását az önkormányzattól a járási kormányhivatal hatáskörébe ruházta át (BAKÓ-MOLNÁR 2016).
} 
és egyéb transzferjövedelmekből való megélhetése szinte lehetetlennek tünik, a másodlagos munkaerőpiacon próbálnak jövedelemhez jutni, ahol az alkalmi és a feketemunka mellett jelenik meg a közfoglalkoztatás nyújtotta esély is, amely lehetőségért küzdelem folyik a településeken (BASS 2010). Az államilag támogatott, másodlagos munkaerőpiac - amelynek része a közmunkaprogram - célja a szociális feszültségek csökkentése és a mindennapi megélhetés biztosítása. A helyi- és távolabbi városokban végezhető alkalmi munkák és az önkormányzat által biztosított lehetőségek mellett az emberek növények terméseinek gyűjtéséből és ezek leadásából tudnak plusz jövedelmet szerezni, amit fa-, valamint vasgyüjtésből származó bevételekkel egészítenek ki (SOLT 2010).

A Bass-féle LHH kistérségek gyermekes háztartásainak reprezentatív mintáján alapuló kutatás (BASS 2010) szerint a leszakadó térségben élő családok mindössze 50,5\%-a szerez jövedelmet az elsődleges munkaerőpiacról, ami kiegészülhet gyessel, nyugdíjakkal, esetenként segélyekkel. Ök alkotják a „piaci típust”. Az „alternatív típusba" tartozó 23,8\% viszont már kiszorult az elsődleges munkaerőpiacról, de az alkalmi- és feketemunka lehetőségeit, illetve a közmunkaprogram által kínált állásokat kihasználva, a segélyek és családtámogatási rendszer elemeivel kiegészített jövedelmükből el tudják tartani családjukat. Ugyanakkor a „segélyezett típusba” tartozók (13,2\%) sem az elsődleges, sem pedig az alternatív munkaerőpiacról nem tudnak jövedelemhez jutni. Ezen típusok mellett találhatók a „,két lábon állók” (12,5\%), akik a bejelentett munkájukból származó jövedelmüket kiegészítik legális-, vagy feketemunkából származó bevétellel, esetleg alacsony arányban a közmunkaprogramban is részt vesznek, illetve kaphatnak segélyeket és transzferjövedelmeket is.

3. táblázat - A leghátrányosabb helyzetü kistérségekben élö családok jövedelemforrás szerinti típusai

\begin{tabular}{|l|c|c|c|c|}
\hline $\begin{array}{l}\text { A jövedelem } \\
\text { forrása }\end{array}$ & $\begin{array}{c}\text { Segélyezett } \\
\text { családok }\end{array}$ & $\begin{array}{c}\text { Alternatív } \\
\text { jövedelemből } \\
\text { élő családok }\end{array}$ & $\begin{array}{c}\text { Két lábon } \\
\text { álló családok }\end{array}$ & $\begin{array}{c}\text { Piaci típusú } \\
\text { jövedelemből } \\
\text { élő családok }\end{array}$ \\
\hline Bejelentett munka & - & - & $95,8 \%$ & $94,7 \%$ \\
\hline Mellékfoglalkozás & - & - & $17,2 \%$ & $7,3 \%$ \\
\hline Vállalkozás & - & $55 \%$ & $20.2 \%$ & $14,4 \%$ \\
\hline Közmunka & - & $45 \%$ & $60,7 \%$ & - \\
\hline Alkalmi munka & - & $29,6 \%$ & $37,2 \%$ & - \\
\hline Feketemunka & - & $23,4 \%$ & $21 \%$ & - \\
\hline Nyugdíj & $41,9 \%$ & $49,4 \%$ & $28,7 \%$ & $25 \%$ \\
\hline Gyes, gyed, gyet & $47,7 \%$ & $63,8 \%$ & $37,4 \%$ & $19,3 \%$ \\
\hline Segély & $62,6 \%$ & 500 & 262 & 1061 \\
\hline N & 278 & \multicolumn{5}{l}{ Forrás: BASS 2010} & \\
\hline
\end{tabular}


DiEbel ANDREA és SzARVÁK TiBOR (1997) egy periférikus településen élők túlélési stratégiáinak kategorizálásakor hasonló csoportokat tapasztaltak. Az „állami segítségre várók” közösségébe tartoznak azok, akik megelégednek az állami támogatásokkal, nem tesznek erőfeszítéseket az elhelyezkedésre, és közmunkát is csak kötelezettség miatt vállalnak. Ezzel szemben a „megkapaszkodók” a hosszú távon gondolkodás során megragadnak minden alkalmi munkalehetőséget, és a feketegazdaságban is jó teljesítménnyel megbecsülést vívnak ki. A „fontolva haladók” tisztában vannak helyzetükkel, és tudatosan kiszámolva igénybe vesznek minden lehetőséget, de az állami segélyekre csak kiegészítő jövedelemként tekintenek. A szerzőpáros szerint legrosszabb helyzetben a ,felesleges emberek diplomával" csoport tagjai vannak, akiknek megszerzett tudása használhatatlan az adott térségben, és nagyon nehezen alkalmazkodnak a körülményekhez.

A szegénység területi elrendeződésében az ezredforduló sem hozott változást (KoÓs 2015B), sőt a 2001-ben megvalósult minimálbér-emelés hatására tovább csökkent a segélyezett munkanélküliek elhelyezkedési esélye, amely leginkább a magas munkanélküliséget produkáló, elmaradott régiókban fejtette ki hatását (KERTESI-KÖLLÖ 2004). Az elsődleges munkaerőpiactól való távolsággal arányosan meghatározhatóan csökken a megszerezhető jövedelem mértéke (BASS et al. 2002), tehát nem meglepő, hogy azok a családok, akik csak szociális támogatásokból és transzferjövedelmekböl élnek, jelentősen rosszabb helyzetben vannak, mint azok, akiknél valamely családtag rendelkezik rendszeres munkabérrel.

\subsection{Közfoglalkoztatás munkaerő-piaci (re)integrációs hatása}

A közmunkaprogram komoly szerepet játszik a hátrányos helyzetü emberek megélhetésében, ezért fontosnak tartom áttekinteni e szociál- és foglalkoztatáspolitikai eszköz célját, várt és megvalósult hatásait. A kormány által 2008-ban létrehozott „Út a munkához" program jelentős forrást kapott a hazai közfoglalkoztatás kiterjesztésére (Koós 2016), majd a szociális törvény módosítását követően 2009-ben ennek tapasztalatira építve vezették be az önkormányzatok által koordinált „Út a munka világába” elnevezésű közcélú programot, azzal az elképzeléssel, hogy minél több embert vezessenek vissza a munka világába (SZABÓ 2013). Ezzel a szociális támogatásokból élők foglalkoztatásának javítását próbálták ösztönözni oly módon, hogy segély helyett munkabért kapjanak és visszavezessék őket az elsődleges munkaerőpiacra (G. FEKETE 2016, KöLlÖ 2015, KolTAI 2015). A közfoglalkoztatás 2011-ben szinte teljesen 
átalakult: megszünt a közmunkaprogram és a közhasznú munkavégzés, amelyek helyett egy egységes közfoglalkoztatási rendszert hoztak létre (KoÓs 2016), ami a 2010-es évek legjelentősebb foglalkoztatási programjává vált (CSERES-MOLNÁR 2014A).

A közfoglalkoztatás pozitív eredményei között érdemes megemlíteni, hogy egyfajta kapcsolatot alakít ki az elsődleges munkaerőpiacról tartósan kiszorult emberek és a munka világa között (SIPTÁR-TÉSITS 2014, VELKEY 2014A), valamint hozzájárul e csoport munkaképességének megörzéséhez (SCHARLE 2015), vagy éppen kialakításához. Emellett a kedvezőtlen gazdasági- és foglalkoztatási mutatókkal rendelkező területeken is képes a segély összegénél magasabb jövedelmet biztosítani (TíMÁR et al. 2015, CSERES 2015, TÉSITS-ALPEK 2015). Ez azért kiemelten fontos, mert a Belügyminisztérium 2014es adatfelvétele szerint a közmunkások 73\%-a hátrányos helyzetü településen élt (KoÓs 2016 idézi: BM 2015). Viszont a program számos kontraproduktív eredménnyel járt: a közmunka csökkenti a valódi munkaeröpiacon való elhelyezkedés esélyeit (CSERESMOLNÁR 2014B, BAKÓ et al. 2014), mivel a munkaügyi központ (kormányhivatal) általában azokat küldi közfoglalkoztatásba, akiknek az elhelyezkedési esélyeit alacsonynak ítéli meg. Továbbá a közmunka során végzendő feladatok egyszerűek (CSERES-MOLNÁR 2015), könnyen megoldhatóak, így nem fejlesztik a dolgozók kompetenciáit (BASS 2010). Ezt a munkáltatók is tudják, ezért kevésbé hajlandóak munkát adni a közmunkaprogramban részt vevő személyeknek, hiszen az átlagosnál alacsonyabb termelékenységet kapcsolnak hozzájuk (SCHARLE 2012). Így a közmunka nem tudja megvalósítani reintegrációs célját (VELKEY 2014B), hiszen nem javítja a résztvevők foglalkoztatásának esélyeit (KÖLLÖ-SCHARLE 2011, FAZEKAS-SCHARLE 2012). Bár a kutatások eltérő képet festenek a közmunkaprogram családok anyagi helyzetére gyakorolt hatásáról (TÍMÁR et al. 2015, BASS 2010), hosszú távon nem tud jelentősen javítani a háztartások anyagi helyzetén, hiszen akadályozza a munkaerőpiacra való visszakerülést (BASS 2010). A közmunkaprogram többnyire a legrosszabb munkaerő-piaci tulajdonságokkal rendelkezők számára kínál lehetőségeket (TÉSITS et al. 2015), amely szintén hozzájárul a helyzet konzerválásához (SZABÓ 2013, MESSING 2012, FIRLE et al. 2007).

A BASS LÁSZLÓ (2010) által vezetett, közmunkaprogramot vizsgáló kutatás szerint az elsődleges munkaerőpiacra történő vissza-, vagy elhelyezkedésre természetesen a kedvezőbb munkaerő-piaci tulajdonságokkal rendelkező csoportoknak jóval magasabbak az esélyeik. Míg az iskolázatlanok, a romák és a szegénységben élő tartósan munkanélküli emberek mindössze 4-5\%-a jutott állandó munkához a közmunkaprogram során, addig a képzettebb, a nem roma és a nem szegény környezetből érkező 
közfoglalkoztatottak 20\%-a tudott elhelyezkedni. Összességében a 2007 és 2010 között a közfoglalkoztatásban dolgozó emberek 10\%-a kapott állást az elsődleges munkaerőpiacon, viszont ugyanebben az időszakban azon munkanélküliek, akik nem vettek részt a közmunkaprogramban, 24\%-uk jutott állandó munkához.

A közfoglalkoztatásban dolgozó emberek között magasabb arányban vannak tartós munkanélküliek, akik a munkanélküliség időtartamát alapul véve nehezebben kerülnek vissza az az elsődleges munkaerőpiacra (FIRLE et al. 2007). Érdekes, hogy BASS LÁszLÓ (2010) eredményei szerint az alkalmi és feketemunkát végzők nagyobb eséllyel jutnak munkához a nyílt munkaerőpiacon, mint a közmunkaprogramba részt vevő emberek. Ennek oka persze az is lehet, hogy közmunkát eleve azon személyek vállalnak, akik kevés esélyt látnak az elsődleges munkaerőpiacon való elhelyezkedésre. További nehézséget jelent, hogy a forráshiánnyal küzdő - és intézményi leépítésre kényszerülö önkormányzatok személyzeti igényüket gyakran a közmunkaprogramban alkalmazott, sokszor korábbi közalkalmazotti státuszban lévőkkel pótolják (VÁRADI 2015), hiszen a jelenlegi müködési feltételek mellett a költségvetés szempontjából kifizetődőbb közfoglalkoztatottként alkalmazni egy dolgozót, mint személyi állományba venni (Messing 2012, CsoBA et al. 2012). A Szegénységellenes Hálózat kutatása szerint a közmunkaprogramban dolgozók 20\%-a folytatja ugyanazt a szakképzettséget igénylő munkát az önkormányzat alkalmazásában, mint amelyet korábban közalkalmazottként (FARKAS et al. 2014) végzett.

A tartósan munkanélküli, szegénységben élő rétegek megélhetési stratégiái zárványosodtak, amelyben komoly szerepet játszott, hogy a tartós munkanélküliség kezelését az önkormányzatok feladatává tették (VÁRADI 2010). A kistelepülések polgármesterei a közmunkások kiválasztása mellett a munkafeladatok szétosztásában és felügyeletében is részt vesznek. Ezáltal a közmunkaprogram amellett, hogy megfelelő eszköze a szociális feszültségek csökkentésének, rögzíti és erősíti a jelenlegi paternalista jellegű rendszert (VIRÁG 2009). Több kutató szerint a közmunkaprogram azon célja, hogy visszavezesse a résztvevőket az elsődleges munkaerőpiacra (CSERES 2015) nem csak azért illúzió (KOLTAI-KULINYI 2013), mert periférikus térségekben alacsony mértékben állnak rendelkezésre elsődleges munkaerö-piaci kapacitások (VÁRADI 2016A, 2016B), hanem mert a közfoglalkoztatás nem ösztönöz teljesítményre, így nem motiválja dolgozókat a munkavégzésre, tehát nem készíti fel őket az elsődleges munkaerő-piaci körülményekre (VÁRADI 2010). Ennek értelmében viszont a társadalmi mobilitást sem képes elősegíteni (TóTH et al. 2017). Ezenfelül csökkenti az álláskeresési hajlandóságot (KolTAI 2014), hiszen a közmunkaprogram bár a minimálbérnél alacsonyabb, de a 


\section{A kutatás földrajzi területe}

\subsection{A célterületek kiválasztásának indoklása}

A dolgozat kérdéseinek vizsgálatához olyan területet, települést és településrészt kerestem, ahol korábbi fejezetekben bemutatott területi- és társadalmi hátrányok halmozottan vannak jelen, így megfelelően tudják reprezentálni a periférikus területeken élők munkaerő-piaci nehézségeit. A mintaterületek kiválasztásánál alapvető aspektus volt, hogy mindkét vizsgálati téregység a hozzákapcsolódó területen belül a leginkább elmaradott település és településrész legyen, illetve földrajzi elhelyezkedés tekintetében periférikus helyzetet foglaljon el. Tehát - a fentebb kifejtett - MARGARITA SCHMIDT (2007) által meghatározott definícióban leírt területi tulajdonságokat figyelembe véve, regionális perspektívából vizsgálva olyan területek lettek kiválasztva, ahol gazdasági-, társadalmi- és szociális körülményeket tekintve a leghátrányosabb helyzetü emberek élnek. Emellett területi szempontok szerint kiemelt kritérium volt, hogy mindkét célterület ugyanazon földrajzi-, gazdasági- és közigazgatási térséghez tartozzon, ezért a kiválasztott települések mind regionális, mind pedig megyei szinten egyazon területi egység vidéki és központi részét képesek reprezentálni. A kiválasztásnál törekedtem, hogy a periférikus mintaterületek a regionális és megyei településhierarchia két különböző - lehetőleg minél nagyobb eltéréssel megjelenő - szintjét képviseljék. Ennél fogva a két kiválasztott terület bemutatása lehetőséget nyújt a vidékhez köthető periféria jellegzetességeinek, és egy központi maghoz, centrumhoz kapcsolódó városi periféria sajátosságainak megismerésére és összehasonlítására.

A kutatás kérdéseire adott válaszokat, és a periférikus területek munkaerő-piaci jellegzetességeit egyrészt Tiszabő község példáján mutatom be, amely megfelelően képes reprezentálni a vidéki periférián élő hátrányos helyzetű emberek munkaerö-piaci lehetőségeit, hiszen amellett, hogy a Közép-Tisza vidékén kialakult belső periférián helyezkedik el (FAZEKAS 2010), a 2010-es években több alkalommal (legutóbb 2014ben) Magyarország legszegényebb települése (RUdOLfNÉ KATONA 2015) lett. A centrumhoz közeli, városi perifériát reprezentáló mintaterületnek a szolnoki Törteli úti szegregátumot választottam, amely azonfelül, hogy Szolnok városhatárán belül, tehát regionális és megyei szinten központi helyen található, a település szempontjából mégis periférikus területen helyezkedik el, és rendelkezik minden olyan - korábban definiált tulajdonsággal, amely a periférikus térségeket jellemzi.

Az alábbiakban regionális szinttől indulva a megyei helyzetképen át a lokális, helyi viszonyokon keresztül bemutatom ezen hátrányok kialakulásának folyamatát és a 
mintaterületek földrajzi jellegzetességeit, valamint társadalmi- és gazdasági helyzetük kiváltó okait.

2. ábra - A mintaterületek elhelyezkedése Magyarországon és Jász-Nagykun-Szolnok megyében

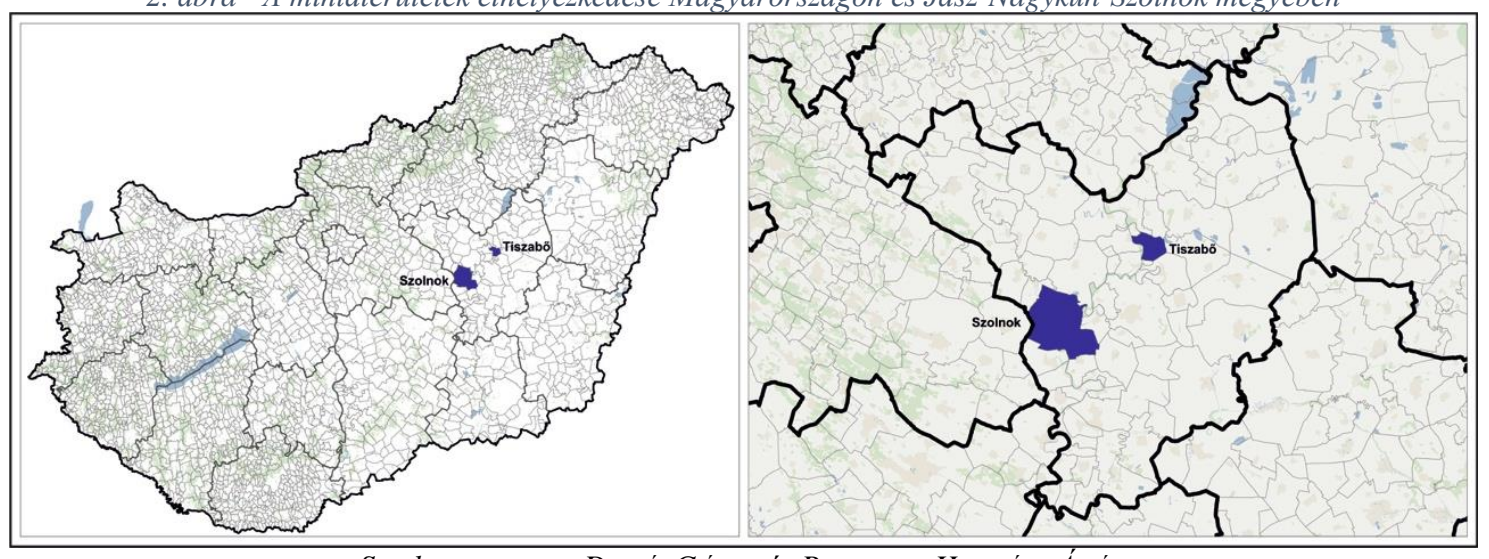

Szerkesztette: DR. DUDÁS GÁBOR éS ROZGONYI-HORVÁTH ÁDÁM

3.2. Az Észak-Alföld és Jász-Nagykun-Szolnok megye gazdaság- és társadalomképe

A '90-es évektől kezdődő gazdasági válság erőteljesen hatott a foglalkoztatottság visszaesésére, amelynek eredményeként gyorsan átalakult a kisfalvak társadalma. Ennek elsődleges okát a kistelepüléseken tapasztalható átlagosnál nagyobb arányú munkahelymegszünések jelentették (BAJMÓCY-BALOGH 2002B); a társadalmi és gazdasági leszakadás és a leghátrányosabb helyzetű települések kialakulása - ÉszakMagyarország és Dél-Dunántúl mellett - az Észak-Alföld régióban volt jelentős. A régióban kialakuló munkanélküliséget elsősorban a KGST-re épülő mezőgazdaság és feldolgozóipar hanyatlása okozta (PÉNZES 2010), amely miatt a szektor jelentős értékesítési válságba került (SÜLI-ZAKAR-LENKEY 2014). Ennek eredményeképp az Észak-Alföld kistelepülésein (TÉSITS-ALPEK 2017) felére csökkent a munkavállalók száma, ezért a falvak eltartóképessége nagymértékben visszaesett (KovÁCS 2008). A foglalkoztatottság csökkenése különösen a Közép-Tisza-vidék településein volt látványos, és különösen érzékenyen érintette a cigányságot (PÉNZES 2013). A gazdasági szempontok mellett az ezzel szorosan összefüggő foglalkoztatási, valamint egészségügyi és demográfiai aspektusból is (SZABÓ 2005) az Észak-Alföld jelenleg hazánk egyik legelmaradottabb régiója és legfejletlenebb területe (TíMÁR et al. 2012).

A kedvezőtlen foglalkoztatási struktúrát jelzi, hogy a nyilvántartott álláskeresők száma (61.852 fö) itt a legmagasabb ${ }^{18}$ az országban, amely a régióban élő gazdaságilag aktív korúak 9,1\%-át jelenti (NFSZ 2018). A háztartások munkaerő-piaci aktivitását

\footnotetext{
${ }^{18}$ Az összes álláskereső 25,7\%-a él az Észak-Alföldön.
} 
tekintve országos szinten e régióban a legalacsonyabb az egy före jutó jövedelem (DOMÁN 2014). A régió kistérségeinek több, mint háromnegyede gazdasági szempontból stagnálónak vagy lemaradónak tekinthető, közülük szigetszerűen emelkednek ki a nagyobb városok (Szolnok, Debrecen, valamint Nyíregyháza) és vonzáskörzetük (FALUVÉGI 2004). Bár az Észak-alföldi térség az egyik legurbanizáltabb régió Magyarországon, viszont számos itt található város funkcióhiányos településnek minősül (SZABÓ 2005), és csak néhány város jelenít meg a modern jellemzőket (TíMÁR-VELKEY 2016).

Az Észak-Alföldön a közlekedési infrastruktúra - elsősorban a közút- és vasúthálózat - jelentősen elmaradott (SZABÓ 2005). Mivel a tőke azokat a területeket részesíti előnyben, ahol az infrastrukturális feltételek megfelelőek (VÁTI 2004), ezért az Észak-Alföld régióban a vállalatok nem érdekeltek a befektetésekben és a munkahelyteremtésben, hiszen olyan alapvető folyamatok vállnak nehézkessé, mint az áruszállítás, vagy a munkaerő bejárása, amely növeli a költségeket és lassítja a gazdasági növekedést, tehát komoly szerepet játszik egy adott cég versenyképességében.

A közlekedési infrastruktúra megléte térben összeköt területeket, hiánya pedig izolációs hatással bír, ezért a vonalas úthálózatok állapota és a közlekedési lehetőségek minősége jelentős befolyással van a régió gazdasági fejlettségére (VÁTI 2004). Tehát az infrastrukturális fejlesztések hiánya és az Észak-Alföld közlekedésföldrajzi helyzete kihat az ott élők foglalkoztatási- és jövedelmi viszonyaira, így az életminőségükre és a társadalmi integrációjukra is (SzABÓ 2005). A szegénység szempontjából leginkább meghatározó társadalmi tényezők között elsők között szerepel az alacsony iskolai végzettség, de az etnikai - leginkább roma - származás, valamint a családok gyerekszáma és a rurális lakókörnyezet is alapvetően befolyásolja a szegénységet (FóNAI et al. 2007, KIM 2011). Az alacsony foglalkoztatási rátát pedig elsősorban az alulképzettek magas inaktivitására (TÉSITS 2007B) lehet visszavezetni, a hátrányos helyzetü kistelepüléseken élő aktív korú álláskeresők között pedig igen magas az alacsony iskolai végzettséggel rendelkezők száma (ROZGONYI-HoRVÁTH 2018). Az Észak-Alföld régió lakosságának iskolai végzettsége minden mutatót figyelembe véve elmarad a hazai átlagtól (SZABÓ 2005), amely természetesen kihat a foglalkoztatottságra is. 2014. szeptemberi adatok szerint az általános vagy annál alacsonyabb iskolai végzettséggel rendelkező nyilvántartott álláskeresők 27\%-át az Észak-Alföldön vették nyilvántartásba, de az alulképzett pályakezdő regisztrált álláskeresők aránya is (30\%) itt a legmagasabb az országban (NFSZ 2014). Az aktív korú lakosság Észak-Alföldön mérhető, országos átlagnál alacsonyabb aránya (LIPTÁK 2014) hosszútávon komoly 
gazdasági hátrányokat okoz a régió számára (SZABÓ 2005). Mivel a háztartásokban élők gazdasági aktivitása kiemelkedően hat a családok életminőségére, a régióban tapasztalható alacsony foglalkoztatottság mellé társuló magas eltartotti arányszám az egyik legnagyobb akadálya a térség gazdasági fellendülésének (SzABÓ 2005).

A kedvezményezett járásokat meghatározó - 290/2014. (XI. 26.) kormányrendelet 17 fejlesztendő járást és további 36 komplex programmal fejlesztendő járást állapít meg Magyarországon (Zsom 2015).

3. ábra - Magyarország kedvezményezett és fejlesztendö járásai

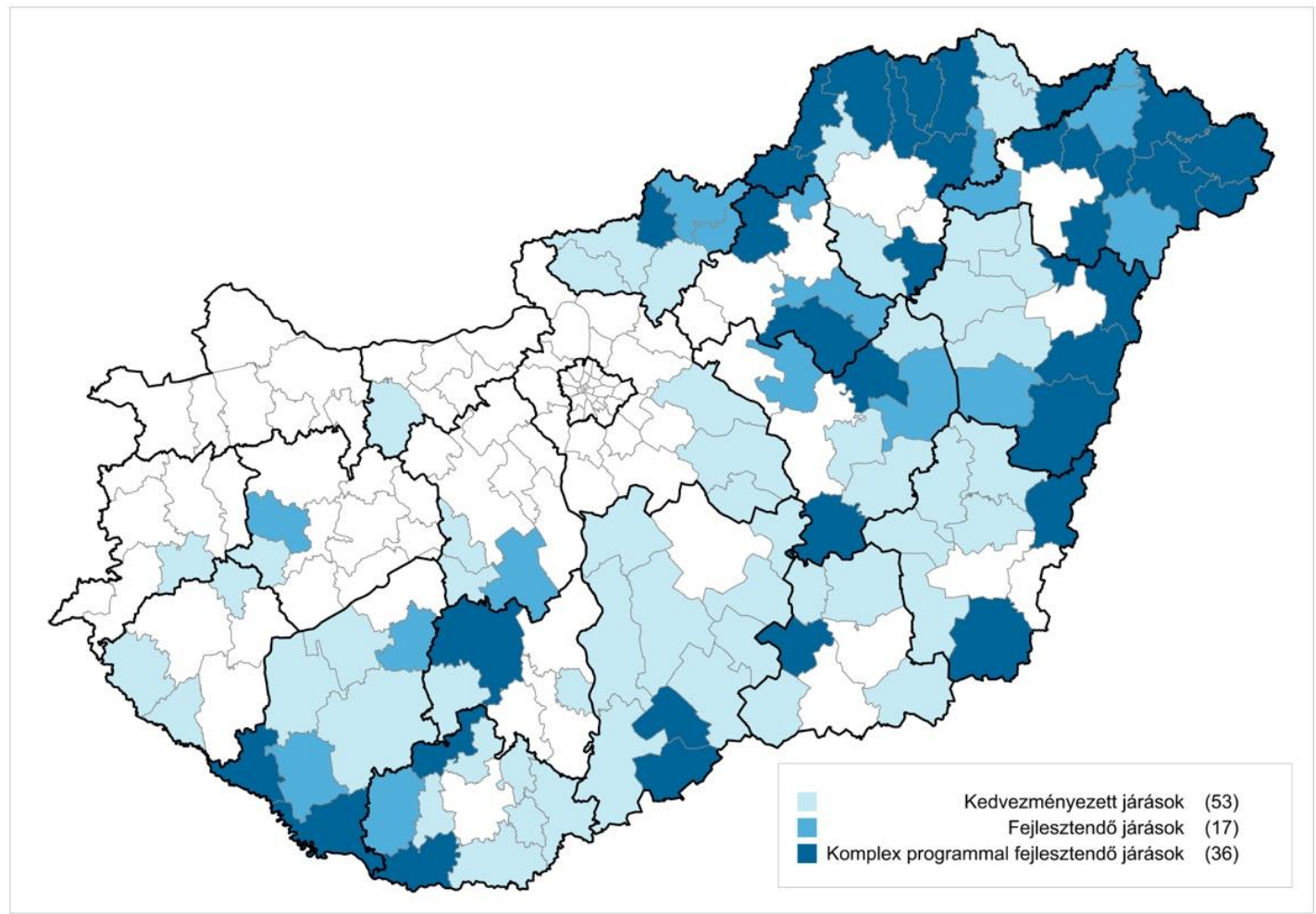

Forrás: ZSOM 2015 alapján DR. DUDÁS GÁBOR és ROZGONYI-HORVÁTH ÁDÁM szerkesztette

A rendelkezés szerint fejlesztendő, vagyis leghátrányosabb helyzetü járásokban él az ország lakosságának közel 15\%-a. Az LHH járásokban élő emberek 42,5\%-a az ÉszakAlföldön lakik, sőt, 8,9\%-uk Jász-Nagykun-Szolnok megye valamelyik településén (MAGYAR KÖZLÖNY 2014A). Így nem meglepő, hogy Észak-Magyarország mellett az Észak-Alföldön a legmagasabb a leghátrányosabb helyzetű kistérségek/járások aránya és itt a legalacsonyabbak a foglalkoztatási mutatók, valamint egy före jutó éves jövedelem, amely mindössze az országos átlag 83\%-át teszi ki (Zsom 2015). 
6. táblázat - A leghátrányosabb helyzetü járásokban élők száma Magyarországon, 2014

\begin{tabular}{|l|cc|}
\hline \multicolumn{1}{|c|}{ Terület } & $\begin{array}{c}\text { Leghátrányosabb } \\
\text { helyzetü területeken } \\
\text { élök emberek száma }\end{array}$ & $\begin{array}{c}\text { Leghátrányosabb helyzetü } \\
\text { területeken élök aránya az } \\
\text { összlakossághoz képest } \\
\mathbf{( 9 . 8 7 7 . 3 6 5} \text { fö) }\end{array}$ \\
\hline Magyarország & 1.476 .307 fö & $14,9 \%$ \\
\hline Észak-Alföld régió & 627.463 fö & $6,3 \%$ \\
\hline Jász-Nagykun-Szolnok megye & 131.597 fö & $1,4 \%$ \\
\hline \multicolumn{2}{|r|}{ Forrás: MAGYAR KÖZLÖNY 2014A, saját szerkesztés } \\
\hline
\end{tabular}

A fenti folyamatok eredményeként az Észak-Alföld - Észak-Magyarországgal, a Dél-Alfölddel és a Dél-Dunántúllal együtt - Európa 20 legszegényebb régiója közé tartozik (Eurostat 2017). Nem mellesleg egy 2010-es felmérés (DOMONKOS-HERCZEG 2010) alapján az Észak-Alföld 204 településén összesen 425 szegregátum található, amely szerint a régió minden második $(52,4 \%)$ településén fellelhető legalább egy szegénytelep.

A szocializmusban jelentős iparosítás zajlott Jász-Nagykun-Szolnok megyében, amelynek hatásai még most is érződnek. A megyére jellemző a korszerü ipari termelöágazatok jelenléte (BACSIK 2013, VÁROS-TEAMPANNON 2012) - amelyek az Észak-Alföld régió gazdasági teljesítményének 47,8\%-át adják (JNSZM 2017) -, a multinacionális tőke és a megye gazdaságát meghatározó cégek elsősorban Szolnoki, a Törökszentmiklósi és a Jászberényi járásban összpontosulnak (VÁROS-TEAMPANNON 2012, JNSZM 2017). A megye nagyobb foglalkoztatói közé tartoznak a szolnoki vasúti jármüjavító (Stadler Szolnok Vasúti Jármüjavító Kft.), az autóalkatrész gyár (Jopp Interior Hungary Kft.), és a bőrgyár (Eagle Ottawa Hungary Kft.), ezenfelül Martfün cipőgyártás, Törökszentmiklóson pedig mezőgazdasági gépgyártás folyik, Jászberényhez pedig elsősorban háztartási gépgyártás kapcsolódik. Emellett Jászfényszarura települt Európa egyik legnagyobb televíziógyára (Samsung Electronics Magyar Zrt.), Tószegen pedig Magyarország legtöbb embert foglalkoztató kerékpárgyára (Accel Hunland Kft.) található. A Jász-Nagykun-Szolnok megyében található 12 ipari park összesen 5000 embert alkalmaz (BACSIK 2013), a megye lakosságának területi eloszlása és a népsürüség mértéke pedig összefüggést mutat a helyi gazdaság teljesítményével és a munkalehetőségek számával. A megyében a mezőgazdasági termelés és a kapcsolódó iparágak is hangsúlyos szerephez jutnak, viszont a rendszerváltás óta jelentősen csökkent a - hagyományosan erős - állattartó ágazat szerepe, amellyel párhuzamosan a foglalkoztatási és jövedelemtermelő képesség is redukálódott (VÁROS-TEAMPANNON 2012). Az egy före jutó GDP jóval az országos átlag 
alatt található, amely a megyék rangsorában a 15 . helyen áll, az egy före jutó jövedelem pedig az Észak-Alföld régió átlagértékétől is elmarad (JNSZM 2017, VÁROSTEAMPANNON 2012).

A megye városhálózatát elsősorban csökkenő népességmegtartó és tőkevonzó képességű kisvárosok alkotják, és mivel nincsenek nagyobb vonzóhatással rendelkező városok, Pest megye és Hajdú-Bihar megye elszívó hatásával nem képes tartani a versenyt. Jász-Nagykun-Szolnok megye kelet-nyugati átjárhatósága erősen limitált, amelynek okai között szerepel a Tisza hidak alacsony száma, az útkapacitások helyzete és a leromlott közúthálózat. Ezek eredményeként a megye belső kohéziója gyengének mondható (VÁROS-TEAMPANNON 2012).

Jász-Nagykun-Szolnok megye kedvezőtlen társadalomképéhez hozzájárul az országos átlagtól elmaradó iskolázottsági szint, amelynél bár a 15 év felettiek körében az általános iskolát befejezők 93\%-os aránya csak 2,2\%-kal marad el a hazai átlagtól, a 25 év felettiek körében mért felsőfokú végzettség arányát jelző 13,3\% már jelentősebb különbséget mutat az országosan mért 19\%-hoz képest (JNSZM 2017). Az alacsony képzettségi mutatók mellett a foglalkoztatottsági, és a legfőképpen a Tiszántúlra jellemző munkanélküliségi adatok is a népesség helyzetének lemaradását jelzik. A megye foglalkoztatottsági rátája $57,3 \%$, és mivel a munkaképes korú inaktívak általában alacsony iskolai végzettséggel és szakképzettség nélkül próbálnak elhelyezkedni, ezért a megyében nyilvántartott álláskeresők 29,6\%-a két évnél hosszabb ideje nem talál állást. A Jász-Nagykun-Szolnok megyében tapasztalható társadalmi- és gazdasági különbségek megmutatkoznak a foglalkoztatottsági adatokban is, hiszen míg a Jászberényi járásban mindössze 3,6\% a munkanélküliek aránya, addig - a Tiszabőt is magában foglaló Kunhegyesi járásban 12\%-ot tesz ki az álláskeresők hányada, amely egyben az ország legszegényebb járásai közé tartozik (VÁros-TEAMPANNON 2012). A közfoglalkoztatottak számát tekintve a Szolnoki után közvetlenül a Kunhegyesi járásban alkalmazták a legtöbb közmunkást a megyében. A megyei közmunkaprogramban részt vevő munkavállalók több, mint fele legfeljebb alapfokú végzettséggel rendelkezik, viszont egyharmaduk szakmunkás, vagy szakközépiskolai bizonyítványt szerzett. A megye lakosságának egészségi állapota is elmarad az országos átlagtól, az ezredfordulótól kezdve pedig felgyorsult a lakosság elöregedési dinamikája, és mivel 10 év alatt 8\%-kal esett vissza a megyei lakosság száma, a népességvesztés üteme az országos átlagnál négyszer nagyobb mértékü (VÁROS-TEAMPANNON 2012). 


\subsection{Tiszabő, a rurális jellegủ periférikus térségek mintaterülete}

\subsubsection{Tiszabö földrajzi elhelyezkedése és lakossági összetétele}

Tiszabő a Közép-Tisza-vidék belső periférikus területén, Jász-Nagykun-Szolnok megye északi részén, a Kunhegyesi járásban (4. ábra) található, összesen 3504 hektáron elterülő, 2094 fős település (KSH 2015). A falut közúton Budapestről Fegyvernek felöl a 4-es számú föúton érhetjük el, míg közösségi közlekedéssel szolnoki átszállással, autóbusszal közelíthető meg. Tiszabőt a vasút elkerüli, a legközelebbi megálló Fegyvernek-Örményes, amely 15 kilométerre található a falutól, a község határában viszont egy komp köti össze a Tisza két oldalát. A település térbeli megközelíthetősége annak zsákfalus jellege miatt nehézségekbe ütközik, ami jelentősen meghatározza fejlödési lehetőségeit (PAPP et al. 2017). A falut nyugatról a Tisza, a többi irányból mezőgazdaságilag hasznosítható terület határolja (SZEGÖ 2010).

Tiszabő jelenlegi településkapcsolati kiterjedtsége megegyezik az 1920-as években tapasztalható területtel, piacos helyei között Törökszentmiklóst, Fegyverneket és Kunhegyest lehet említeni, míg gravitációs központként Törökszentmiklós szolgál (SZILÁGYI 2015). A falut is magába foglaló Kunhegyesi járás 2013 óta létezik újra, amelyhez hét település (Kunhegyes, Abádszalók, Tiszabö, Tiszagyenda, Tiszabura, Tiszaroff és Tomajmonostora) tartozik. A járás a szomszédos Jászapáti és Hevesi járásokkal együtt összefüggő belső perifériát alkotnak (KSH 2016C).

4. ábra - Tiszabö elhelyezkedése Jász-Nagykun-Szolnok megyében és a Kunhegyesi járásban

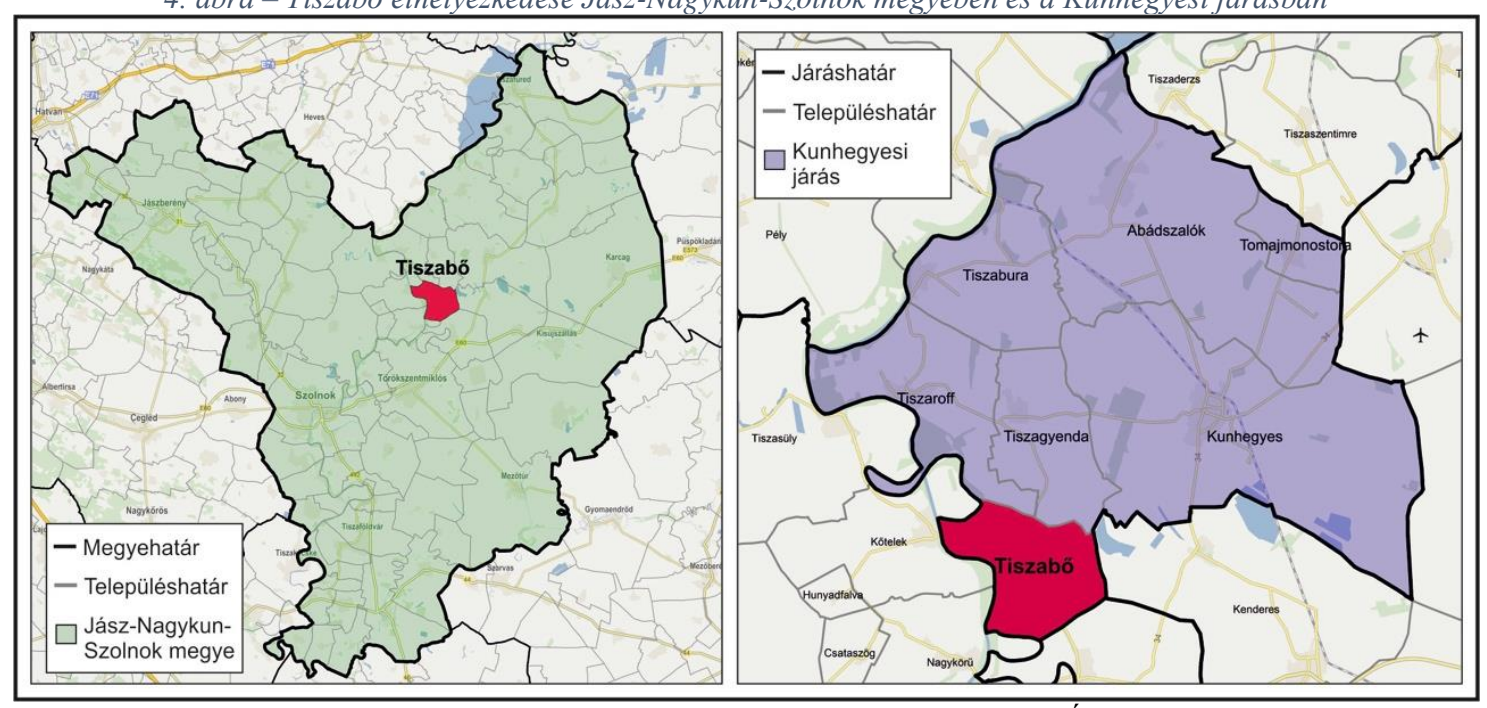

Szerkesztette: DR. DUDÁS GÁBOR és ROZGONYI-HORVÁTH ÁDÁM

A romák aránya a teljes falubeli lakossághoz képest 89\% (HORVÁTH 2014), noha más vizsgálatok 90\% feletti értéket mutatnak, nem romák pedig csak az idősebb korosztályban találhatók a faluban (PÁSZTOR 2013). A falu lakónépességének száma az 
utóbbi másfél évszázad során jobbára állandónak mondható: míg 1870-ben 2148 fö, addig 2018-ban 2291 fö volt a lakosok száma (HoRVÁTH 2018). 1990-ben volt a népességminimum, amelyet elsősorban elvándorlás okozott, ezután a népességszaporulat miatt egyensúlyba került a falu lakossága. A kistérség többi településével ellentétben itt természetes szaporulat volt mérhető, éves átlagban 2-3\%-os népességnövekedési ráta figyelhető meg (PÁsZTOR 2013), annak ellenére, hogy az egészségügyi alapellátás háziorvos, fogorvos - több, mint tizenhárom éve hiányzik a településröl (LUDESCHER 2017). Tiszabő társadalmának fiatalodó jellegét a 2011-es népszámlálási adatok is jól szemléltették: a családokban élő gyermekszám a falvak országos átlagának kétszerese volt.

7. táblázat - Átlagos gyermekszám településtipusonként, 2011

\section{Településtípus}

100 családra átlagos gyermekszám

\begin{tabular}{|l|r|}
\hline Hazai városokban átlagosan & 104 gyermek \\
\hline Hazai falvakban átlagosan & 115 gyermek \\
\hline Tiszabőn & \\
\hline & 226 gyermek \\
\hline
\end{tabular}

Emellett a fiatalok kiemelkedően magas arányát jelzi, hogy minden ötödik falubeli (381 fö) még nem töltötte be a hetedik életévét, tízből négy (769 fö, 38,7\%) tiszabői lakos pedig még gyermekkorú (14 éves vagy fiatalabb) - ezzel megyei szinten az élen jár. A 60 év felettiek aránya pedig mindössze $6,3 \%$, ami a legalacsonyabb a megye többi településéhez képest (KSH 2013). Jelenleg Tiszabő a kistérség legfiatalabb települése, ellenben itt a legnagyobb a munkanélküliség is: a 2011-es népszámlálási adatok szerint a falu 448 háztartásából átlagosan minden másodikban (48\%) található olyan személy, aki dolgozik (KSH 2015).

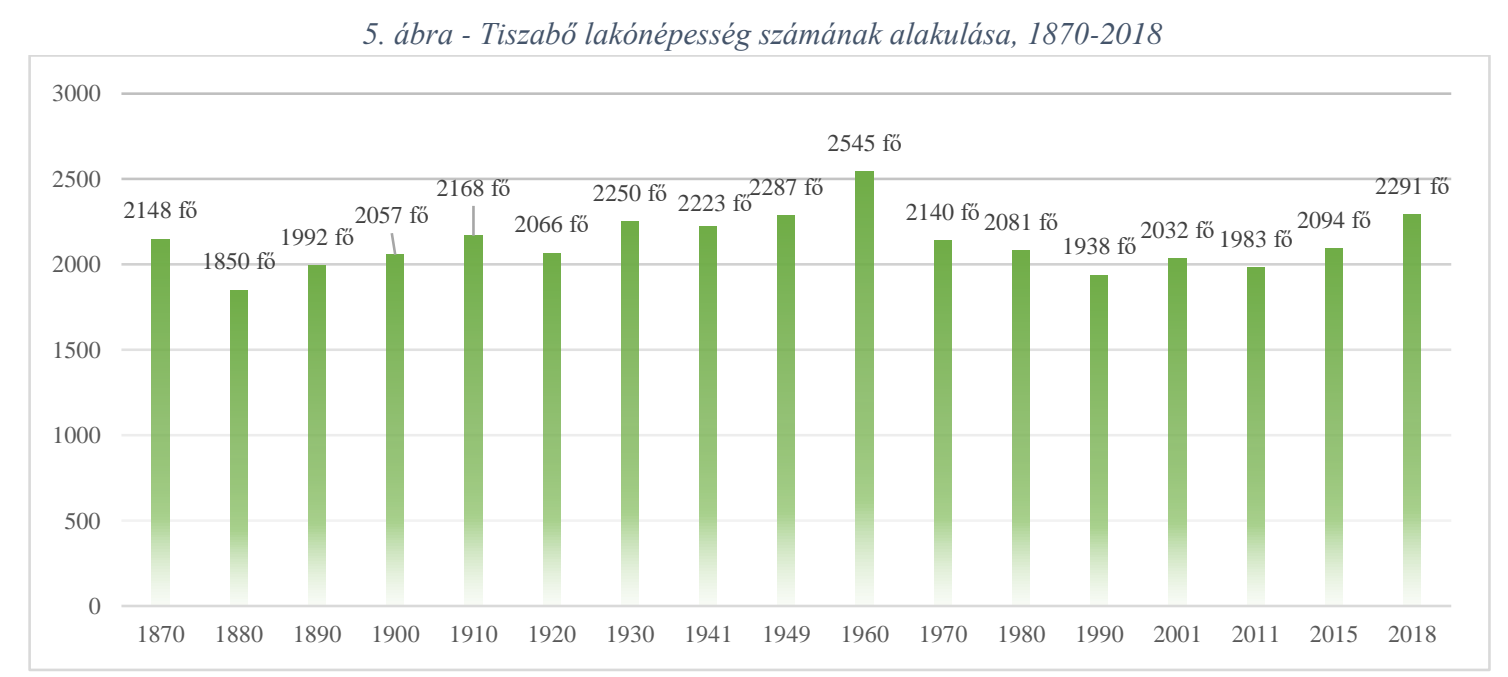

Forrás: NÉPESSÉG.COM adatai alapján saját szerkesztés 
A falu eltartóképességének alacsony szintjét mutatja, hogy a lakosságnak csak 54,9\% (1089 fö) aktív korú, 100 munkaképes korúra 71 gyermekkorú és 11 időskorú jut. A megyében itt a legmagasabb azok aránya, akik az általános iskola első évfolyamát sem fejezték be, ők a 10 éves és annál idősebb népesség 2,9\%-át alkotják (KSH 2013). Annak ellenére, hogy korábbi, 2012-es felmérésem idején nem találkoztam a faluban élö értelmiségi személlyel (HORVÁTH 2014), a 2011-es népszámlálási adatok alapján a tiszabőiek 0,4\%-a ( 8 fö) felsőfokú végzettséget - egyetemi, vagy főiskolai diplomát szerzett (KSH 2013).

\subsubsection{A falu szegregálódási és periferizálódási folyamata}

A hátrányos helyzetü kistérségek és a periférikus területek helyzetének alakulásában általában jelentős szerepet játszott a rendszerváltás (PÉNZES 2010, KERTESI-KÖLLŐ 2001, GYENEI 1993B), de Tiszabő esetében ez a folyamat jóval korábban kezdődött. A település gazdag agrárfalunak számított, a 19. század elején járási székhelyi rangot is kapott, a század második felében pedig már az ipar töltött be meghatározó szerepet Tiszabő életében, ahol gyufa-, ecet-, sör- és szeszgyár is munkát adott a lakosoknak. Helyi - járási szinten a legmagasabb arányú - zsidó kereskedők is élénkítették a falu kereskedelmét, amelyet a település saját kompja is segített (SZEGŐ 2010). Ekkoriban a falu lakosságának körülbelül 10\%-a volt cigány származású (SEBESTYÉN 2002). A kiegyezés körüli modernizáció eredményeként megépült SzolnokDebrecen vasútvonal (1857. november 25.) viszont elkerülte Tiszabőt, amelynek hatására az ipari vállalatok elköltöztek a faluból. A település a mezőgazdaságban látta meg a fejlődés lehetőségét, annak ellenére, hogy az évenkénti $500 \mathrm{~mm}$ körül csapadékátlaggal Tiszabő Magyarország egyik legszárazabb területén található. Ezután a falu lakóinak megélhetését sokáig ez az ágazat jelentette (SZEGÖ 2010).

Tiszabő jelenlegi lakosságának többsége szülei által, a szocializmus időszakában hozott döntések következtében költözött a településre. Ebben közre játszott az 1960-61as téeszesítési kampány (LADÁNYI-VIRÁG 2009), valamint az 1961-es MSZMP KB határozat is, amely próbálta felszámolni Magyarország 2100 cigánytelepét. Ezek a döntések a városokat övező falvak számára teremtettek kedvezőtlen feltételeket (HAJNÁCZKY 2013). Az 1960-as években Jász-Nagykun-Szolnok megyében történt kitelepítéseket erősítette a Tisza-tavi erőmü és tározó 1968-ban kezdődött építése is, amelyek következtében a városokban élő cigánycsaládok egy részét - a környező falvak mellett - Tiszabőre telepítették. E döntések hatására az ezt követően megkezdődött nem 
roma lakosság folyamatos elvándorlása miatt egy marginalizációs folyamat vette kezdetét, és mára egy majdnem homogén cigánylakosságból álló falut eredményezett (ZOLNAY 2013).

Tiszabő volt az egyike azon településeknek, ahol az 1961-es párthatározat végrehajtására kiadott 1-72/1961.I. számú utasítás eredményeként lefektetett telepfelszámolási tervezet megvalósítását megkezdték ${ }^{19}$. Ennek eredményeként az 1960-as évek elején a település déli határától kezdődően létrejött az első szegregátum az Akácos utcában (6. ábra). A hatalom nyomására a település egészén szétszórt betelepítés mellett döntöttek, a telepen élők számára pedig támogatták a falu belterületén történő lakásvásárlást (TóTH et al. 2012).

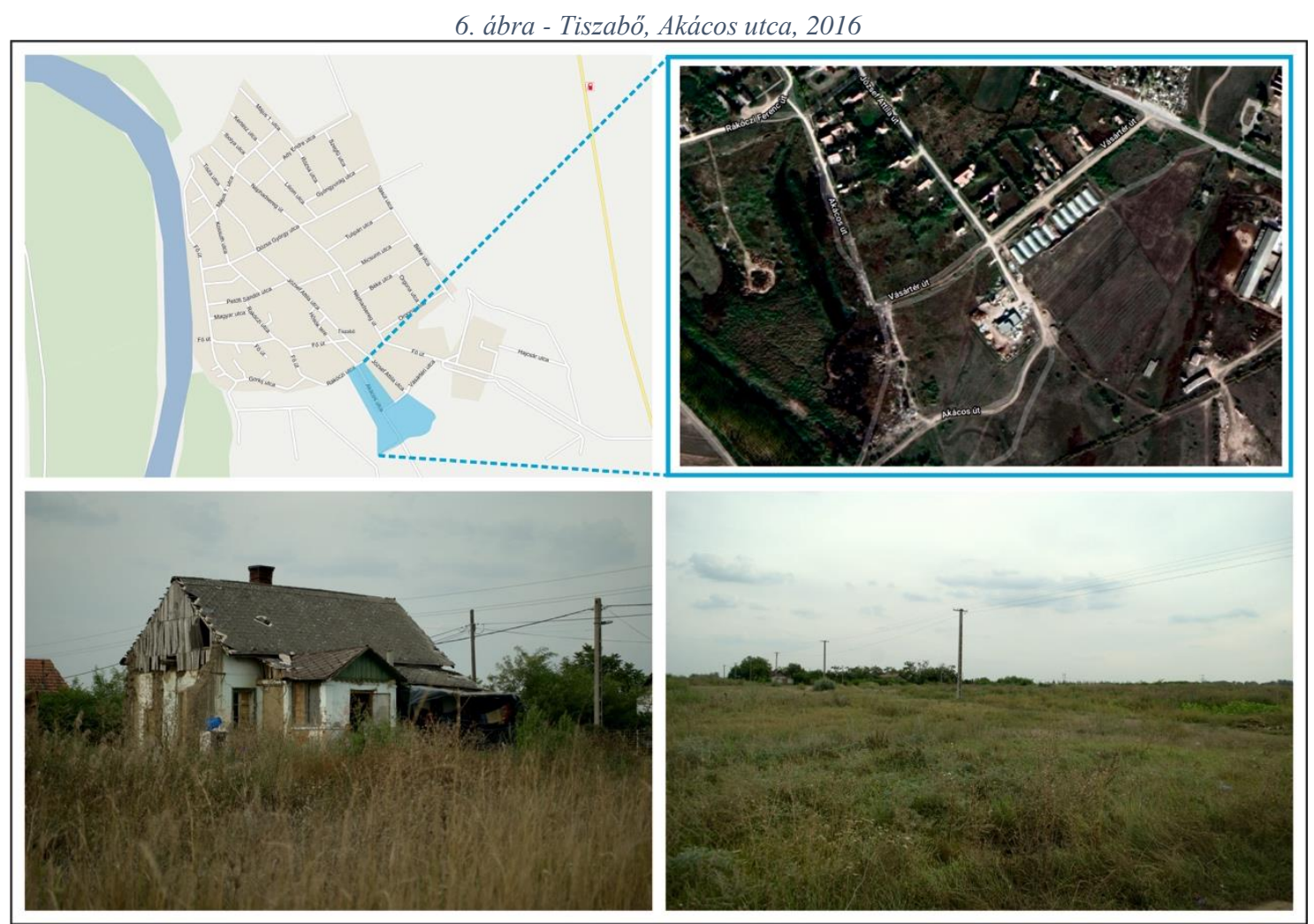

Forrás: MAPS.GOOGLE.HU és saját képek, DR. DUDÁS GÁBOR és ROZGONYI-HORVATTH ÁDÁM szerkesztette

\footnotetext{
19 A Magyar Forradalmi Munkás Paraszt Kormány elnökhelyettese, Apró Antal 1-72/1961.I. sz. utasításával elrendelte, hogy a rendszeresen dolgozó cigányokat a lakásigénylésnél az egyéb lakásigénylőkkel egyenlően bírálják el, valamint a cigány családok saját erejéből való építkezését fokozottan kell támogatni. Ezt kedvezményes házhelyekkel, társadalmi munka megszervezésével, és selejtes, bontásból származó építőanyagok kedvezményes áron való értékesítésével igyekeztek elérni. A szegénytelepek teljes megszüntetéséig fokozottan gondoskodtak a terület kommunális ellátottságának, és az egészségügyi vizsgálatok színvonaláról és a felvilágosításról (HAJNÁCZKY 2013).

A telepek felszámolására Vendégh Sándor, a Nemzetiségi Osztály vezetője szerint azért volt szükség, mert a hazai cigányság társadalmi asszimilációjának egyik feltétele a lakáshelyzetük javítása. A határozat szerint a romák 40-80\%-a lakott ekkoriban putriban. E körülmények felszámolását és a cigány családok lakáskérdését próbálták ezzel a szemlélettel megoldani, amely a pártállam hivatalos álláspontjává nőtte ki magát. Ennek alapján az MSZMP KB Politikai Bizottsága 1961. június 20-án fogalmazta meg a cigányság helyzetének javításáról szóló határozatát, amely magába foglalta a cigánytelepek felszámolását is (HAJNÁCZKY 2013).
} 
Tiszabő gettósodása a szakirodalomban meghatározott mintáktól eltérően, egyedi utat járt be $\mathrm{e}^{20}$. A település etnikai viszonyainak sajátosságát jelzi, hogy nem az általános gyakorlatnak megfelelő tömbös telepítés szerint költöztették be a romákat, hanem egy lakásvásárlási program által jutottak új otthonhoz (TóTH et al. 2012). Az 1960-as évek elején még csak 255 ember lakott szegregátumban, amely a falu lakosságának 10\%-át jelentette, de az 1961-es határozat hatására jónéhány telepi család kezdett el építkezni az Akácos úton. Tiszabő szinte az egyetlen olyan település, ahol meg is valósult a CSlakások elszórt építésének gondolata (GYENEI 1993B), mivel a község tanácsa úgy látta, ha újabb családok építkezését engedélyeznék az Akácos utcában, akkor egy újabb cigánytelep kialakulását támogatnák. Így ,ebben az esetben valóban olyan környezetbe kerülnének a cigány családok, amelyek feltétlenül hatással vannak szokásaik, magatartásuk stb. alakulására” (JNSZML 1965 idézi: TóTH et al. 2012). A községi tanács a CS-lakásprogram kezdetétől egészen 1982-ig, vagyis a szegregátum felszámolásáig kitartott a cigánycsaládok szétszórásának koncepciója mellett. Egy újabb cigánytelep kialakulásának elkerülését a program 1974-es módosítása ${ }^{21}$ is támogatta, hiszen az Építésügyi Minisztérium lehetővé tette, hogy kedvezményes hitelt lakásvásárlásra is fel lehessen venni. Ennek köszönhetően már a falvakban megüresedő házakat is meg lehetett venni, amennyiben nem ütköztek a tanács, az eladó, vagy a falu lakosságának az elöítéletébe (TÓTH et al. 2012). Ezzel pedig lehetővé vált a cigány lakosság településen belüli migrációja.

A szabad házvásárlás lehetőségének következtében - a kedvezmények igénybevételével - az 1980-as évek végéig tudtak házakat vásárolni a faluban élő cigányok. Az erőltetett asszimilációs folyamat viszont a községben élő nem cigányok életminőség-színvonalának csökkenését eredményezte, és a falu korábbi képe és lakosságának kohéziója is megingott.

A község régi cigánytelepe ugyan megszünt, de a roma családok beköltözésével párhuzamosan a település belterületének egyes utcái a telephez hasonló színvonalúvá váltak. A kialakult konfliktusok hatására a nem cigány lakosok elköltöztek (GYENEI 1993B), akiknek házait cigány származásúak vásárolták meg, így Tiszabőn egyre több telepszerű rész alakult ki, és 1989-re a teljes szegregációból az egész településre jellemző szétszórtság jött létre. Következésképpen a párthatározat elképzelése a cigány családok falu társadalmának részévé tételére nem járt sikerrel, hiszen egy teljes szukcessziós

\footnotetext{
${ }^{20}$ Részletesebben lásd: Melléklet 1.

21 30/1974. (XII.4.) PM-ÉVM sz. Együttes rendelet „az állampolgárok tulajdonában lévő, üresen álló családi házak értékesítéséröl”
} 
folyamatot váltott ki, amely során az 1960-ban tapasztalt 10\%-os cigány etnikai arány 1986-ban 45\% (LENGYEL 1991), 1990-re (csökkenő összlakosság mellett) 50\% (TóTH et al. 2012), 1993-ban már 63\% (ZOLNAY 2012), napjainkban 90\%-ra nőtt (HORVÁTH 2014).

Jelenleg a település lakásállományának jelentős része lepusztult állapotban van, amelyben szerepet játszik, hogy a házak $85 \%$-a hagyományos vályogból, alap nélkül készült (Melléklet 4., 1-7. képek, 13-15. képek, 17-18. kép, 20. kép). A 2000 tavaszán, 11 méteren tetőző árvíz hatására kialakult belvíz 85 házat ledöntött, és körülbelül 400 házat súlyosan megrongált (SZEGŐ 2010), jelentős károkat okozva a falubeliek számára. Az államtól kapott támogatásokból pedig a károsultak közül sokan a környékbeli településeken kezdtek új életet, amelynek nyomát a falu látképe is hordozza az üresen álló telkek formájában (Melléklet 4., 4. kép, 12. kép, 16. kép, 21. kép és 22. kép). Tiszabő egészét értelmezhetjük - SIPTÁR-TÉSITS (2014) osztályozása szerint - periférikus területen található falusi telepként, vagy egyaránt nevezhetjük gettósodott településnek.

Tiszabő két részre tagolódik, amelyet a települést keresztülszegő csatorna határoz meg. A falu déli oldalára eső ,fejfalu” a Tiszabőt a Fegyvernekkel összekötő út felöli részén található, míg a csatornán túli rész az ún. „Kínai negyed”, a falu kisebb, elzártabb területét jelzi (7. ábra). Annak ellenére, hogy az egész település a szegénység minden jelét felsorakoztatja, a falu vonatkozásában is jelentős különbségeket tapasztalni a centrum és a periféria között. A központi rész csendes, nyugodt, tiszta, és a közbiztonság is jónak mondható, a helyi viszonyokhoz mérten jó életkörülményekkel. A csatornán túli terület már rendezetlenebb, a közbiztonság rosszabb, az itteni lakosok életminősége lokális szinten is gyengébb (HORVÁTH 2018).

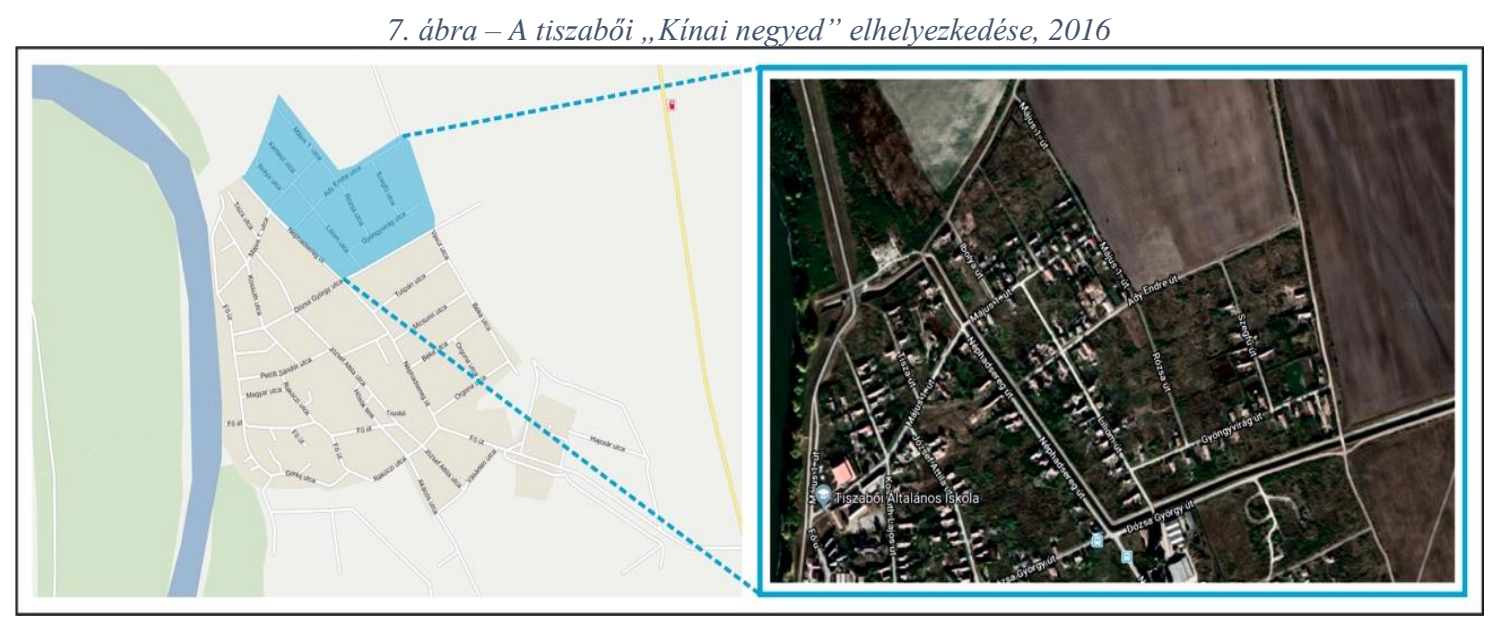

Forrás: MAPS. GOOGLE.HU, DR. DUDÁS GÁBOR és ROZGONYI-HORVÁTH ÁDÁM szerkesztette 


\subsubsection{Tiszabö gazdaságának és a falubeliek munkaerö-piaci helyzetének alakulása}

A szocializmus időszakában Tiszabőn a környékbeli településeknél is erőteljesebb téeszesítés folyt, de a tehetősebb gazdák külön szövetkezeteket alapítva tudták védeni biztos piacukat a tiszai áruszállításnak köszönhetően (ZOLNAY 2012). A termelőszövetkezetben kizárólag nem cigány lakosok voltak, így háztáji földdel is csak ők rendelkezhettek (Melléklet 4., 19. kép). A falu hanyatlása az 1960-as években a cigány lakosok betelepítésével kezdődött (GYENEI 1993B, ZOLNAY 2012), majd hamarosan az MSZMP KB 1968-ban kiadott határozata Tiszabőt a fejleszteni nem kívánt települések közé sorolta (PÁSZTOR 2013), ezt követően megszüntették a tiszai kompot és a kisvasutat, majd a tiszai hajójárat is leállt. Így megszünt a piacozás lehetősége is, később pedig a termelőszövetkezeteket is összevonták.

Korábban Tiszabő egy fontos átkelöhely volt, a folyami közlekedés pedig bekapcsolta a falut a kistérség életébe, de az említett döntések következtében egy mesterséges zsákutcás település jött létre (ZOLNAY 2012). A szocialista vezetés határozatai alapján bezártak az üzemek és az intenzív mezőgazdasági termelés is leállt. Tiszabő demográfiai képe a rendszerváltás időszakára már az öregedő nem cigány őslakosság mellett egy fiatal, betelepült cigány népességet mutatott. A falu társadalma már ekkor - még a többszörösen hátrányos helyzetü települések között is - élen járt az egyetlen osztályt sem végzettek körében (11\%), amely az általános iskolát be nem fejezettek $61,5 \%$-os arányával ${ }^{22}$ együtt jelentősen hozzájárult a tiszabői munkavállalók hátrányos munkaerő-piaci pozíciójához (GYENEI 1993A). A szocializmus utolsó éveiben viszont az iskolai végzettséget és szakmai képesítést igénylő állásokból egyre kevesebb lett, amely természetesen munkanélküliséghez vezetett. 1980-ban már Tiszabőn volt a legalacsonyabb (35,5 fö) a száz lakosra jutó keresők száma a megyében (GYENEI 1993A). Nem meglepő, hogy míg 1987-ben a községben élők közül a megyei átlag kétszerese tartozott a legszegényebb jövedelmi kategóriába, az 1989-es kutatások szerint Tiszabő lakosságának 55\%-a élt - az akkori számítások szerint - a létminimum alatt és a falubeliek 70\%-a nem érte el az egy főre jutó, társadalmilag szükségesnek ítélt értéket. A településen tapasztalható szegénység mértéke már ekkor sokszorosan meghaladta az országos átlagot (GYENEI 1993A). Ezen folyamatok eredményeként a szocialista időszak végére Tiszabő etnikailag szegregálódott, és az elöregedett, valamint az elszegényedett családok településévé vált (GYENEI 1993B).

\footnotetext{
${ }^{22}$ Emellett 19,4\% fejezte be az általános iskolát, 6,8\% végzett középiskolát, valamint 1,3\% föiskolai, vagy egyetemi diplomát szerzett (GYENEI 1993A).
} 
A rendszerváltás utáni foglalkoztatási viszonyok átalakulásának következtében a tiszaböi családok bevételi forrásainak összetétele is átalakult: a családi pótlék kiemelkedő jelentőségüvé vált (42\%-ről 51\%-ra emelkedett) és a háztartások, családok mindennapi fennmaradását biztosító alapbevétel lett. Miközben a munkaviszonyból származó jövedelem aránya drasztikusan - 50\%-ról 16\%-ra - csökkent, fokozatosan nőtt azon családok száma, akik nem tudták fizetni korábban felvett OTP hitelüket, az adósságok halmozódása miatt pedig a falubeliek egymás kezesei lettek, ezért a kezesek is fizetésképtelenné váltak (GYENEI 1993B). Kárpótlással többen földhöz jutottak, de csak néhány agrárvállalkozó (Melléklet 4., 5. kép) müveli a mezőgazdasági területeket (ZOLNAY 2012). A termelőszövetkezet megszüntetése és a falut érintő kárpótlási ügyletek pedig csak emelték a helyiek problémáit (SZEGŐ 2010).

Az 1990-es önkormányzati törvény nyújtotta önálló érdekérvényesítés (VELKEY 2001) lehetőségével a tiszabői önkormányzat is élt. A település a szociális földprogram (SzARVÁK 2000) keretében - minisztériumi támogatással és önkormányzati finanszírozással - közel 100 családnak tudott kedvezményes feltételekkel földet biztosítani. A többségében önkormányzati tulajdonban lévő vállalkozás által üzemeltetett szalmabriketteket készítő gyár müködtetése során az önkormányzat már akkor pénzügyi szabálytalanságok sorozatát követte el, amikor a folyamatosan növekvő forráshiány ellenére is vállalkozásba kezdett. Emellett kezességet vállalt a vállalkozás által felvett hitelre, sőt 1992-ben a forráshiány fedezetére kapott állami támogatás egy részét hiteltörlesztésre fordította. A vállalkozás ellen felszámolás indult, később az adóhatóság is végrehajtással fenyegette a falut (ZOLNAY 2012). Tehát Tiszabő szocializmusban elkezdődött periferizálódó és gazdasági redukciót mutató folyamata a rendszerváltás után is folytatódott, így a falu folyamatosan veszített potenciálértékéből. Ezt a falubeliek relatív jövedelemszintje is jelzi, amely 1988 és 2007 között a PM-APEH és a KSH adatai szerint több, mint 25\%-kal esett vissza, így a község egy főre eső jövedelmi szintje 2007ben az országos átlag 15\%-át sem érte el (PÉNZES 2010).

A KSH 2001-es népszámlálási adatai szerint a faluban 100 foglalkoztatottra 904 inaktív kereső jutott, 2011-ben pedig az itt élő lakosság mindössze 11\%-a (217 fö) volt foglalkoztatva, 8\%-uk (159 fö) munkanélküli, 29\%-uk (578 fö) inaktív kereső, 52\%-a (1029 fö) eltartott volt (KSH 2013). Ekkor 100 före már „csak” 266 inaktív kereső jutott, viszont a feltehetően a közmunkaprogram okozta javulás még mindig a település népességének szerény gazdasági aktivitását jelezte.

Az említett körülmények hatására lett Tiszabő a GFK kutatásai szerint a több alkalommal vásárlóerő tekintetében Magyarország legszegényebb és objektív 
szempontból a legalacsonyabb életminőséget biztosító települése (RUDOLFNÉ KATONA 2015, PAPP et al. 2017), ahol az egy före jutó vásárlóerő az országos átlag 38\%-át produkálta. 2012-ben elindult a Startmunka-mintaprogram, amelynek keretében az első ciklusban 56 embert tudtak foglalkoztatni (PÁSzTOR 2013). Már ezzel is az önkormányzat lett a legnagyobb foglalkoztató a településen. Néhányan más településen találtak munkát és munkaerő-piaci szempontból prosperálóbb településekre ingázással próbálják enyhíteni a falu foglalkoztatási nehézségeit (8. ábra).

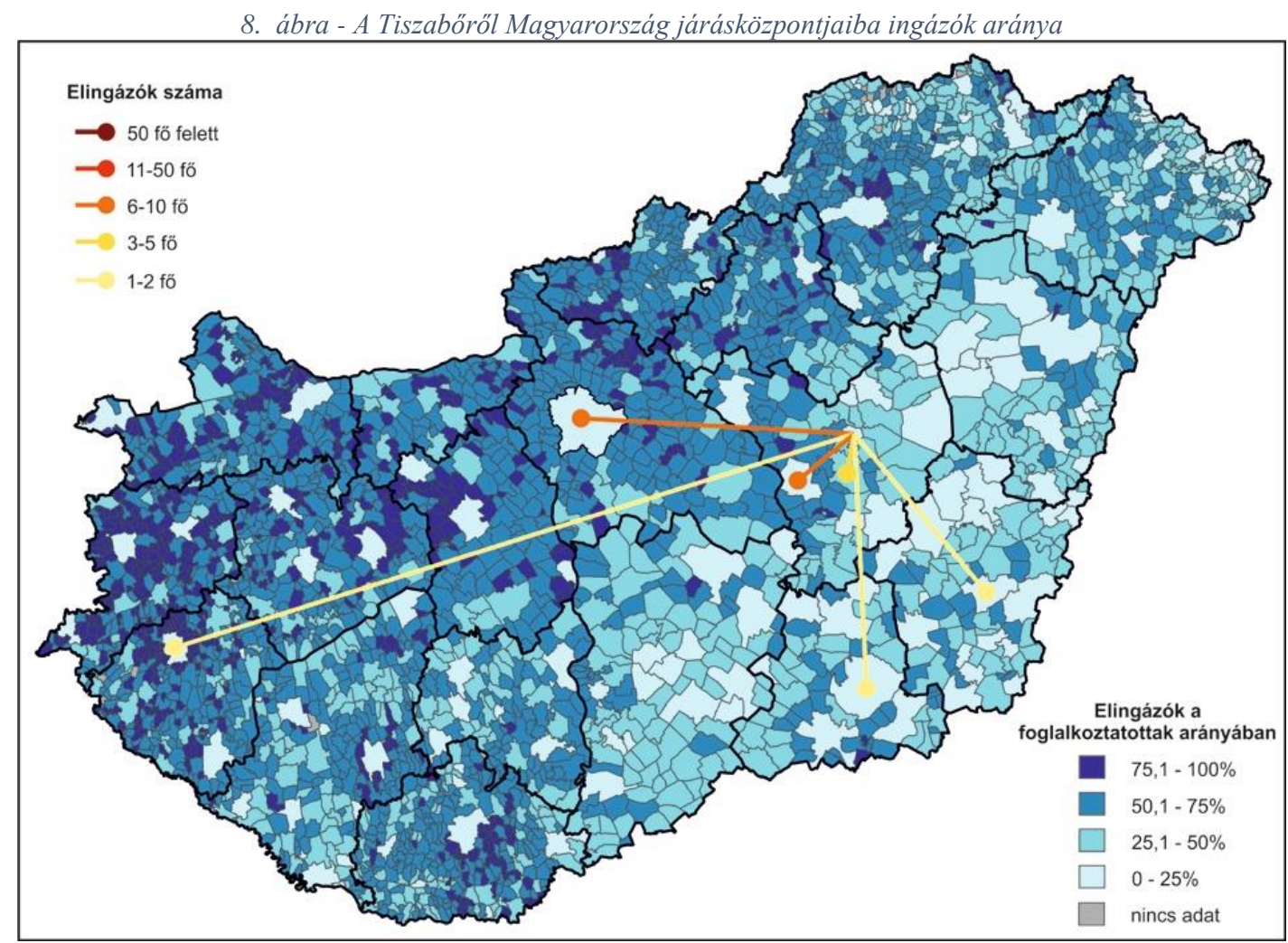

Forrás: WEBMAP.LECHNERKOZPONT.HU alapján DR. DUDÁS GÁBOR és ROZGONYI-HORVÁTH ÁDÁM szerkesztette

A 2011-es népszámlálás szerint jelzett összesen 217 fő munkavállaló 13,4\%-a (29 fő) ingázott más településekre, akik elsősorban (20 fö) valamely járásközpontban kaptak munkalehetőséget. A Lechner Tudásközpont adatai alapján egy átlagos tiszabői ingázó 121 kilométert tesz meg a munkahelyére, amelyet 105 perc alatt ér el. 
3.4. A szolnoki Törteli úti szegregátum, a városi jellegű periférikus térségek mintaterülete

\subsubsection{Szolnok földrajzi elhelyezkedése}

9. ábra - Szolnok elhelyezkedése Jász-Nagykun-Szolnok megyében és a Szolnoki járásban

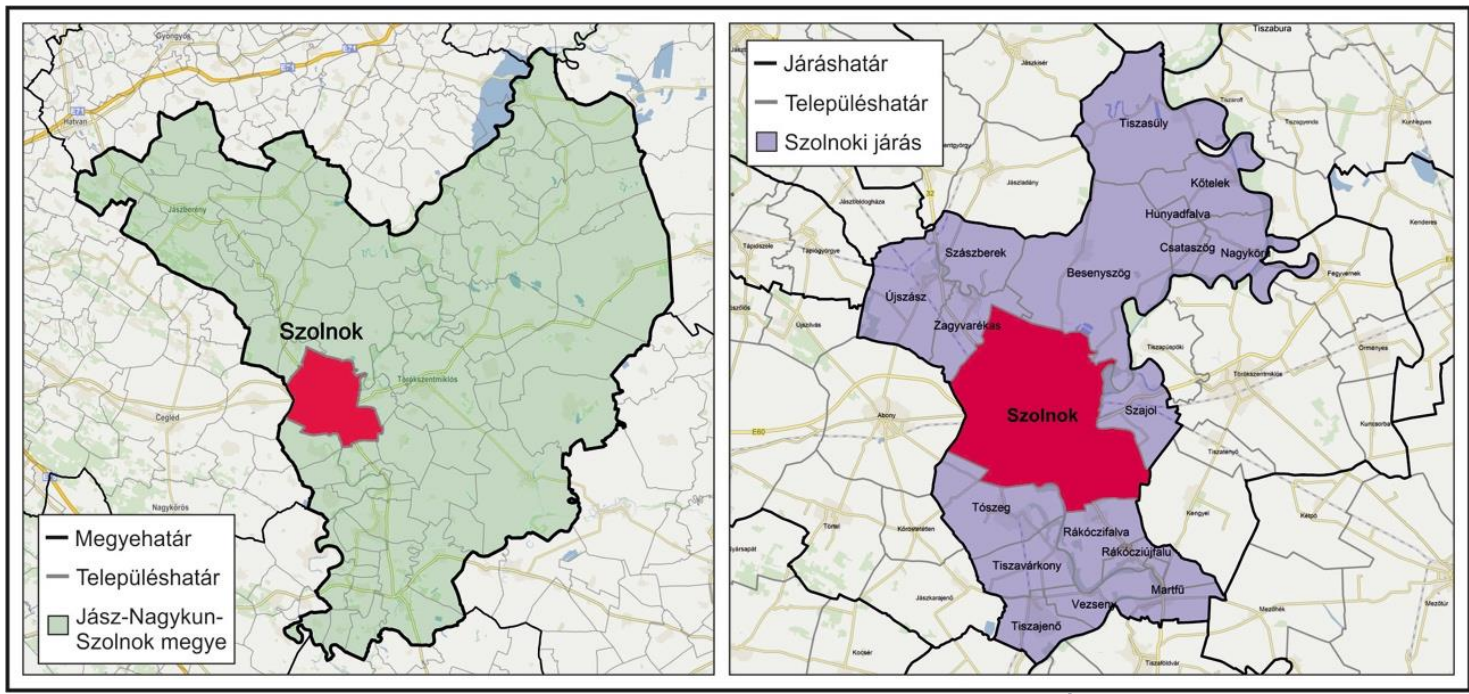

Szerkesztette: DR. DUDÁS GABBOR és ROZGONYI-HORVÁTH ÁDÁM

Szolnok Megyei Jogú Város Jász-Nagykun-Szolnok megye székhelye, az ÉszakAlföld régió egyik legnagyobb települése, gazdasági, közlekedési, katonai, kulturális, oktatási és egészségügyi központ. Közlekedési infrastruktúrája kiemelkedő, közúton Budapesttől az E 60 föúton $95 \mathrm{~km}$ távolságra található, vasúti összeköttetése a fővárossal és az alföldi nagyvárosokkal egyaránt optimális (VÁROS-TEAMPANNON 2012).

Szolnok az Alföld közepén, a Tisza partján, a Zagyva torkolatánál fekszik. Ideális földrajzi elhelyezkedésének köszönhetően a térségben központi szerepet tölt be. A városon átívelő - és a város mellett elhaladó - jelentős forgalmat bonyolító 4-es foút nagymértékben hozzájárult a város fejlődéséhez, emellett a vízi és légi közlekedés, valamint a vasúti iparvágányok lehetővé tették két ipari park és egy logisztikai központ kiépítését (BFH EURÓPA 2017). Ennek ellenére a város népességszáma a rendszerváltás óta folyamatosan csökken: 1990-ben a város lélekszáma közel 79.000 fö volt, amely szám 2011-re 74.500 före fogyatkozott, 2015-re pedig már csak 73.000 főt mutatott (KSH 2015). Szolnok nemzetiségi megoszlásában a romák közel 10\%-os arányt képviselnek (SZARVÁK 2007), akiknek 86\%-a a létminimum alatt él (BFH EURÓPA 2017). 


\subsubsection{A város szegregációs folyamatai}

A cigányság megoszlása Szolnokon nem mondható egyenletesnek, hiszen egyes városrészekben, területeken hosszú időre visszavezethetően magasabb arányban vannak jelen roma etnikai közösségek. A városon belüli eloszlást földrajzi, gazdasági és társadalmi tényezök is befolyásolták, de a pártállami intézkedések történelmi hatásai is irányították a folyamatot, amely során a roma lakosság Szolnok peremterületein lévő életközösségeit a telepfelszámolás időszakában a külső városrészekben felépített, alacsony komfortfokozatú szociális bérlakásokba, vagy CS-lakásokba költöztették (SZMJVÖ 2011). A területi átrendeződésben az 1950-es évektől kezdődő erőltetett iparosítás az ipari területek létrehozásával és szakképzetlen fizikai munkaerőt igénylő munkahelyek kínálatával jelentős migrációs folyamatot indított el Szolnok periférikus, ipari részeinek irányába. A folyamatra a területen élö lakosság befogadókészsége és annak etnikai- és társadalmi viszonyai is pozitívan hatottak (SZMJVÖ 2014B). A városba való költözés legintenzívebb időszaka a 1970-es évek elejétől az 1980-as évek végéig tartott (KOVÁCS 1999, SZARVÁK 2007, THÉKES 2016).

A KSH (RÁCZ 2014) meghatározása alapján Szolnokon négy területi szegregátum található (10. ábra):

1. Üteg-Tüzér utca környéki szegregátum

2. Tücsök-Hangya utcai menti szegregátum

3. Béke-Bogár-Csallóköz utcák környéki szegregátum

4. Törteli út környéki szegregátum

Szolnok önkormányzatának antiszegregációs programja és a népszámlálási adatokból előállított szegregációs index szerint e telepek - vagyis a leghátrányosabb helyzetü lakóterületek - közül a Törtéli út 7. szám alatt található szegregátum jellemezhető a legrosszabb fizikai és társadalmi mutatókkal (SZMJVÖ 2014A). 
10. ábra - Szolnok területén található szegregátumok elhelyezkedése

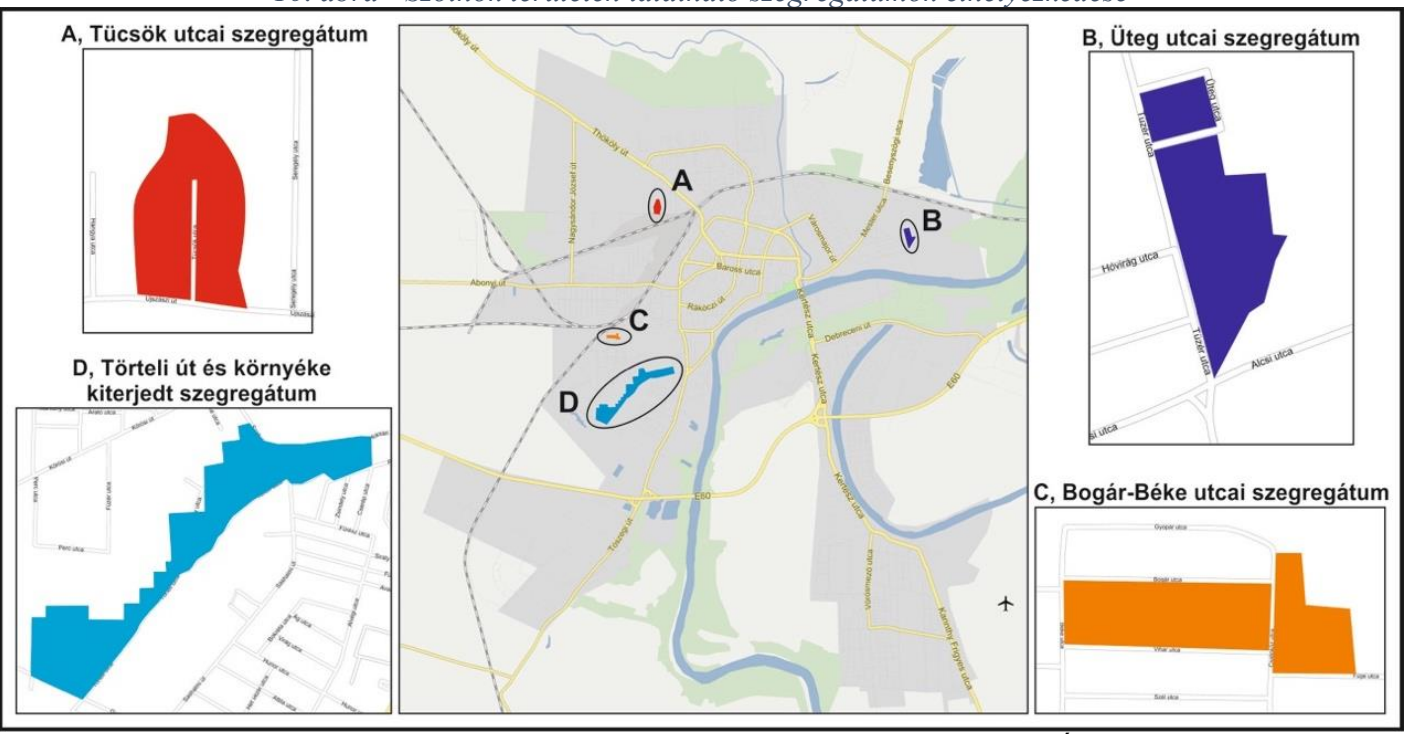

Forrás: SZMJVÖ 2014A alapján DR. DUDÁS GÁBOR és ROZGONYI-HORVÁTH ÁDÁM szerkesztette

\subsubsection{Törteli úti szegregátum elhelyezkedése és Déli iparterület városrész}

A Déli iparterület Szolnok délnyugati, jól lehatárolható részét képezi, amelyet három oldalról a vasút, kelet felöl pedig a Tisza határol. A terület a város központi részéhez a Tószegi út és a 4. számú föúton keresztül kapcsolódik. A területet szórványos beépítettsége miatt alacsony kihasználtság jellemzi. Az ipari park belső infrastrukturális kialakításának köszönhetően viszont vállalkozás-vonzó és fogadó képessége sokat fejlődött (SZMJVÖ 2011).

A városrészt középen elválasztó Gyökér utcától déli irányba a Tiszamenti Vegymüvek (TVM) egykori lakótelepének környékét leszámítva kizárólag gazdasági funkciókkal rendelkező ingatlanok helyezkednek el, északi részén a gazdasági épületek mellett lakóházak is találhatók. Városképi ütközések miatt a terület nem mutat egységes arculatot.

A városrész épületállományának állapota is igen változatos, a lakóterületek presztízse a szegregációs sávok eredményeként nagyon alacsony. Az idetelepülő ipari létesítmények vonzása egy munkáskerület létrejöttét indukálta, a munkahelyek jellegéből adódóan pedig a beköltözők elsősorban alacsony iskolai végzettséggel rendelkező betanított- és segédmunkások voltak. Ez a folyamat két különböző társadalmi csoport a korábban a területen épült CS-lakásokba költöztetett romák és az ipari szektorban elhelyezkedő dolgozók - együttélését eredményezte.

A cigányság esélyei alig változtak a rendszerváltás óta, így a helyi társadalmon belül a szociális különbségek hatalmas méretüre növekedtek (SZMJVÖ 2011). Mára a 
szegregátum körülményei között, mélyszegénységben élő társadalmi csoportok szinte teljesen elveszítették egzisztenciális felemelkedésük és társadalmi mobilitásuk esélyét.

A városrészben két területen találhatóak társadalmi szempontból hátrányos helyzetü csoportok: a Körösi út menti kertvárosi jellegü lakóterületen - ezen belül leginkább a Törteli úti szegregátumban - valamint a Gyopár és Bogár utca környékén, ahol Szolnok leginkább elhanyagolt lakóépületei találhatók (MTA 2004). A városrész lakókörnyezetével való elégedetlenséget mutatja, hogy az itt élő emberek jelezték legmagasabb arányban a Szolnokon belül való lakóhelyváltás igényét (SzARVÁK 2007, SZMJVÖ 2013), a városrészek közül pedig a Déli iparterület demográfiai és társadalmi állapota a legkedvezőtlenebb. A korcsoport összetétele az átlagtól némiképp eltér a fiatalok felé, viszont az iskolázottsági szint a város többi területéhez képest itt a legalacsonyabb: a kizárólag általános iskolai végzettséggel rendelkezők aránya a szolnoki átlag kétszeresét mutatja, a diplomásoké pedig a városi átlag egyharmada (SZMJVÖ 2011).

\subsubsection{A Törteli úti telep szegregálódási folyamata és az ott található ingatlanok helyzete}

A szegregátum helyén korábban a II. világháború vasútbombázásainak eredményeként kialakult - átlagosan 10 méter mély - bombatölcsérek voltak. Később a terület Szolnok kommunális hulladéklerakó helyét alkotta, amelyet a helyhatóság lezárt (SZMJVÖ 2011). A környék jelenleg még a területi feltöltés után is alacsonyabban fekszik a város többi részéhez képest, ami magas talajvízszintet és egy mocsaras területet eredményezett. A problémán a kialakított vízelvezető főcsatorna sem segített, ezért az itt lévő vályogházak folyamatosan veszélyeztetettek. A Törteli úti telep mellett található mélyebb területet ma is „lapos” elnevezéssel illetik (SZMJVÖ 2011).

A telepen található házakat 1986 öszén, egy mintaprojekt keretében komfort fürdőszoba, belső WC, konyha, vezetékes víz és gáz - nélkül adták át, amely épületek a terület helyreállítása után kifejezetten szegregátumnak épültek (11. ábra), ahol a kezdetekben közösségi programok mellett telepgondnok is támogatta a lakók életét (MTA 2004, SZVF 2017). A szegregátumba a város - akkor még - elhanyagoltabb részeiről költöztették a lakókat, akiket a városi tanács jelölt ki. A telepen található négy házsorban összesen 35 lakás lett kialakítva, amelyből három sor $(\mathrm{A}, \mathrm{B}, \mathrm{C})$ önkormányzati bérlakások céljára, egy sor pedig (D) magánlakásoknak épült (Melléklet 5. 23. kép). A házak lakhatatlanná válása miatt a B-sort később lebontották, igaz, teljes egészében már csak a C épületsor áll. A magántulajdonban lévő lakások a „csökkentett értékü” 
lakásprogram keretében épültek magántőke bevonásával, amelyekhez az OTP kedvezményes banki kölcsönt biztosított.

11. ábra - A szolnoki Törteli úti szegregátum elhelyezkedése és látképe, 2016

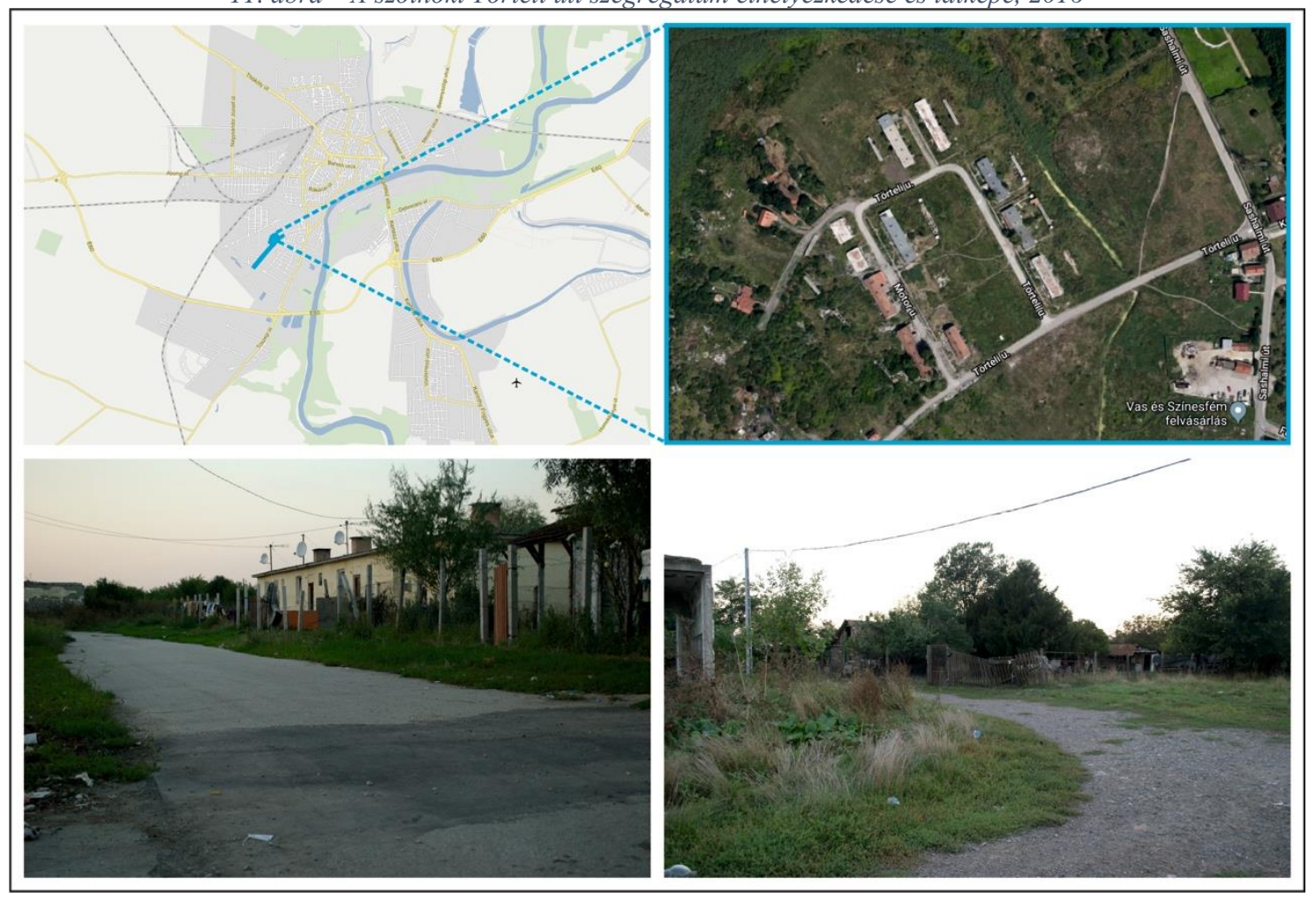

Forrás: MAPS.GOOGLE.HU és saját képek, DR. DUDÁS GÁBOR és ROZGONYI-HORVÁTH ÁDÁM szerkesztette

Az első, telepre költöztetett lakók céltudatos családok voltak, akiket motivált a szegregátumból való elköltözés. Ezért egy részük később otthagyta a lakást, más lakók pedig az elköltözés mellett az önkormányzati tulajdonban lévő ingatlanjaikat bérbe adták, ahová leghátrányosabb helyzetű családok költöztek be hosszabb-rövidebb ideig. Így tulajdonosok által elhagyott, vagy jogszerütlenül kiadott lakások egy részében betelepült családok laknak (SZVF 2017). Mivel a szegregátum lakásai mocsaras-lápos területre épültek, jellegüknél fogva folyamatosan süllyednek. Az átlagosan 45-52 $\mathrm{m}^{2}$ alapterületen $^{23}$, két helyiségből álló lakásokban a zsúfoltság miatt a családtagoknak nincs személyes terük (SZVF 2017), hiszen az idővel leamortizálódott ingatlanokban több generációs - többnyire 8-10 fős - családok élnek ${ }^{24}$. A telepen található házakba az áramszolgáltatás bevezetésre került, de díjhátralék miatt egy részükben a szolgáltató szünetelteti az ellátást. A területen a közmüvesítés - vezetékes ivóvíz, szennyvízelvezetés - infrastrukturálisan ugyan biztosított, viszont a szegregátumhoz

${ }^{23}$ Szolnokon a legkisebb lakásnagyság a Törteli úti ingatlanokra jellemző (SZARVÁK 2007, SZMJVÖ 2013).

${ }^{24}$ Az MTA kutatása szerint esetenként előfordul, hogy a $25 \mathrm{~m}^{2}$-es Törteli úti telepi lakásban tízen laknak együtt (MTA 2004). 
tartozó ingatlanok komfort nélküli kialakítása miatt a hálózatokra való csatlakozás nem lehetséges. Ezért a telepen élők számára a vízellátást közkút biztosítja, de a háztartásvezetéshez szükséges alapvető higiéniai feltételek nem biztosítottak (TKKI 2011). A lakásokhoz tartozó külső mellékhelyiségek egy része lebontásra került, a fennmaradók állapota pedig teljesen leromlott, ezért jelenleg néhány ingatlanhoz nem tartozik illemhely. Ezek helyettesítésére a használaton kívüli lakásokat, vagy a közterületet tudják használni az emberek (Melléklet 5. és 27. kép). A nyílászárók több házról hiányoznak, minden második lakás tetőszerkezete - a rendszeres karbantartás hiánya miatt - csapadékosabb időjárás után beázik, és a falak vizesedése is jellemző probléma $^{25}$ (MTA 2004, SZARVÁK 2007, SZMJVÖ 2013).

A Törteli úti telep egy elhanyagolt, szennyezett, rendezetlen környezeti képet mutat, a terület slumosodásának folyamatához persze hozzájárult a közmüszolgáltatásokra való csatlakozás hiánya is. A házak előtt lévő csapatékelvezetők szeméttel telítettek (Melléklet 4., 25. és 26. kép), a bomlástermékek pedig megfelelö feltételeket teremtettek a rágcsálók és a rovarok elszaporodásának, emellett a területen megjelentek a kóbor kutyák is (MTA 2004). A szegregátumban tapasztalható körülmények komoly egészségügyi kockázatot jelentenek a lakók számára, amelyet súlyosbít, hogy folyóvíz hiánya miatt a tisztálkodás is nehézségekbe ütközik (SZMJVÖ 2006).

A telepen élők többsége a minimális lakásfelszereltségi eszközökkel sem rendelkezik, táplálkozásuk alkalomszerü, öltözetük általában karitatív adományokból származik. A szegregátumban tapasztalható lakó- és életkörülmények miatt gyakoriak a betegségek, az orvosi ellátást viszont csak kevesen veszik igénybe a telepen élők közül. A helyzetet nehezíti a szenvedélybetegségek - dohányzás, az alkohol- és a kábítószerfogyasztás - magas aránya, amely sajnos nagyon fiatalon, esetenként akár öt éves korban is kialakulhat, de az anyukák között is gyakran lehet droghasználókat találni $\left(\right.$ SZVF 2017) ${ }^{26}$.

A szegregátum környezetét némileg javította telepre vezető betonút 2009-ben történt kiépítése, valamint az önkormányzati lakások 2012-es - az ott élők bevonásával történő - felújítása, amelynek köszönhetően a nyílászárókat kicserélték, valamint a falak

\footnotetext{
25 A Törteli út mentén élők 59\%-a jelezte a falak vizesedését és a szigetelés hiányosságát, amelyhez természetesen hozzájárul, hogy az itt épült házak 10\%-a vályogból készült (SZARVÁK 2007, SZMJVÖ 2013).

26 Interjúalanyom elmondása szerint az utóbbi években visszaszorulóban van az alkoholfogyasztás, melynek helyét - az alacsonyabb ár miatt - a kábítószerek (herbál, kristály) vették át.
} 
külső borítása és belső festése is megújult (Melléklet 5. és 24. kép) ${ }^{27}$. Az itt élő családok között nagyon kevés rendelkezik munkajövedelemmel, ezért alacsony lakásfenntartási képességük miatt jelentős állagromlás figyelhető meg a házakon. Emiatt napjainkban a felújítás eredményei már nem láthatók, a fenntartás hiánya pedig az ingatlanok gyors állapotromlásához vezetett. A 2015-ben kialakított - ingyenesen használható szolgáltatópont ${ }^{28}$ viszont lehetőséget nyújt a személyes higiénés igények kielégítésére, valamint a mosás feltételeit is biztosítja a telepen élők számára. Ugyanezen projekt keretében a lakások előtti területek kerítésekkel lettek egymástól és az utcarésztől lehatárolva, és virágokkal esztétikailag díszítve.

A Törteli úti szegregátum SIPTÁR DÁVID és TÉSITS RÓBERT (2014) klasszifikációja alapján egy centrumtérségben található, periférikus elhelyezkedésü, kisméretü, zárt, városi telep. A szegregátum városi periférikus jellegét jelzi a terület szolgáltatásokkal való ellátottsága és közintézményektől való távolsága: a telep 1,5 kilométeres körzetében csak a legalapvetőbb intézmények találhatók; Szent Tamás Görögkatolikus Óvoda és Általános Iskola (12. ábra, F pont; 1,5 km, 18 perc gyalogosan), körzeti- és háziorvosi rendelő (12. ábra, D pont; 1,2 km, 15 perc gyalogosan). Az élelmiszerbolt (12. ábra, E pont; $1,8 \mathrm{~km}, 22$ perc gyalogosan), a közösségi ház és a közösségi közlekedés megállóhelyei csak nehézkesen közelíthetők meg a Törteli úti telep (12. ábra A pont) felől (TKKI 2011). Mivel postás csak alkalomszerűen jár a telepre, a posta épülete pedig szintén a nehezen elérhető helyek közé tartozik, az infrastrukturális hátrányok megbonyolítják a küldemények átvételét és a közüzemi hátralékok kiegyenlítését ${ }^{29}$ is (MTA 2004).

A telepen élők ezeket a szolgáltatásokat - gépjármü hiányában - gyalogosan, kerékpárral, vagy közösségi közlekedéssel tudják megközelíteni, amely jelentősen megnehezíti a gyerekek oktatási-, nevelési- és egészségügyi intézményekbe történő elkísérését is. Szolnok alapvető közszolgáltatásai - az egészségügyi szakellátások, a közmüszolgáltatások központjai, a szociális szolgáltatók - a belvárosban találhatók, amely körülbelül 3,5 kilométeres távolságot jelent az itt élők számára. Ezek elérése évszaktól és időjárástól függetlenül - elsősorban helyi buszjáratokkal lehetséges,

\footnotetext{
${ }^{27}$ Érdekes, hogy a város antiszegregációs programja szerint a telep és környezetének állapota nem teszi lehetővé a terület és az ott élők rehabilitációját. Ezért a szegregátum fokozatos felszámolását javasolja, az ott található lakások felújítása helyett pedig azok bontását és új ingatlanok építése mellett érvel, valamint a higiénés feltételek javítását emeli ki (SZMJVÖ 2014).

28 A Törteli úti telep tisztálkodási lehetőségeinek javítása érdekében Szolnok Megyei Jogú Város Önkormányzata a TÁMOP 5.3.6 11/1 Komplex telep-program keretén belül egy konténerfürdő, mosóhely és toalettek kialakítását valósította meg 2015-ben (Melléklet 5., 28. kép).

${ }^{29}$ A számlák befizetését megkönnyítette néhány lakás előrefizetős mérőórával történő felszerelése.
} 
amelyek 30-50 percenként közlekednek a belváros irányába. A Törteli úti telep közelében a belváros irányába rendszeresen két vonaljárat közlekedik (1 és 1A járat), amelyek legközelebbi megállója 1,2 kilométerre található (12. ábra, B pont; 14 perc gyalogosan $)^{30}$.

12. ábra - Közszolgáltatások megközelítése a Törteli úti telepről indulva

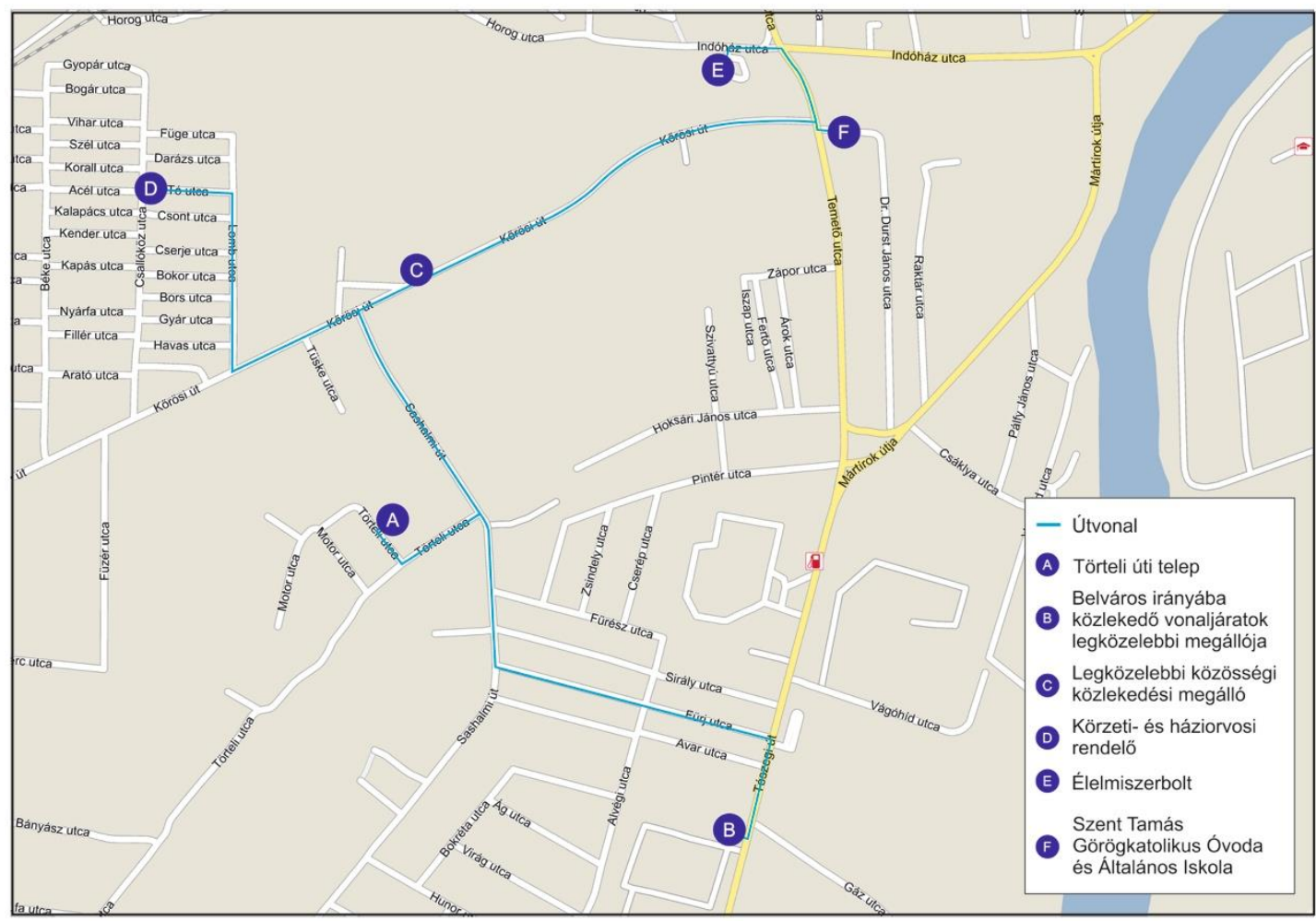

Szerkesztette: DR. DUDÁS GÁBOR és ROZGONYI-HORVÁTH ÁDÁM

A telepen lévő szociális bérlakások krízislakásként funkcionálnak, ezért a szegregátumba és a szomszédos területekre anyagi nehézségekkel küzdő családokat költöztetnek, amely folyamat az elmúlt évtizedekben teljesen átformálta a városrész képét. Az ide költöző családok minimális (átlagosan $3000 \mathrm{Ft}$ ) bérleti díjat fizetnek havonta az önkormányzatnak. A lakbér hosszú távú elmaradása és az önkormányzat felé kialakult tartozások felhalmozódása esetén viszont kiköltöztetik a lakókat, de a telepen gyakoriak a jogcím nélküli beköltözések is ${ }^{31}$.

\footnotetext{
${ }^{30}$ A telephez legközelebbi közösségi közlekedési megállóhely a szegregátumtól 650 méterre helyezkedik el a MÁV Jármüjavítónál (12. ábra, C pont; $650 \mathrm{~m}, 8$ perc gyalogosan). Itt megáll az egész nap közlekedő 3-as járat, viszont ezzel nem érhető el a belváros közvetlenül. Emellett a 20-as és a 34Y-os járat is elérhető innen, viszont - a Középkelet-magyarországi Közlekedési Központ Zrt. (KMKK) 2019. január 2-tól érvényes menetrendje szerint - ezen buszjáratok közül elöbbi csak 12:45-ig közlekedik óránként rendszeresen, majd három órás kihagyással 15:40-kor indul az utolsó járat. A 34Y-os busz mindössze napi két járattal üzemel munkanapokon, amelyek reggel 6:15 és 6:36 perckor indulnak a belváros irányába (kmkk.hu).

31 A telepen élők egy csoportja a lezárt bérlakásokat feltörte, ezzel nem hivatalos módját választva a beköltözésnek. Az önkormányzat a kiköltözés, vagy kiköltöztetés után a lakások nyílászáróinak kivételével próbálta elejét venni az illegális beköltözésnek. Ezeket a lakásokat viszont a környéken élök lebontották,
} 


\subsubsection{A Törteli úti telep háztartásainak helyzete és összetétele}

A 2011-es népszámlálási adatok alapján Szolnok teljes lakosságához képest (74.544 fö) a Törteli ${ }^{32}$ és Motor utcai kiterjedt szegregátumban élők (133 fö) a város lakosságának 0,17\%-át alkották (SZMJVÖ 2014). A telepen élők körében igen magas a fiatalkorúak aránya: míg a 14 éves és fiatalabb korosztály Szolnok teljes lakosságának 13,6\%-át (10.138 fö) alkotja, a szegregátum lakói között a gyermekkorúak aránya 62,4\% (83 fö) volt 2011-ben. Az ott lakó emberek kedvezőtlen egészségügyi állapotát és alacsony várható élettartamát jelzi, hogy a telepen élőknek csupán 2,3 \%-a (3 fö) volt 60 év feletti a népszámlálás idején, miközben a város teljes lakosságában 22\% (16.385 fö) volt a 60 év feletti korosztály aránya (SZMJVÖ 2014).

A telepen található háztartásokban több generáció él együtt, jellemző a fiatalon történő gyermekvállalás és családalapítás (MTA 2004). Az átlagéletkor alapján a Törteli út környéke mondható Szolnok legfiatalabb területének, a gyakran 8-10 gyermekes többgenerációs családok eredményeként itt a legmagasabb a háztartások mérete is (SZARVÁK 2007, SZMJVÖ 2013). A telepen élök körében alacsony a házastársi kapcsolatra épülő család, ellenben jelentős a magát egyedülállónak, vagy gyermekét egyedül nevelő felnőtt, amelynek eredményeként magasabb család- és lakhatási támogatáshoz juthatnak (MTA 2004). A háztartások tagjainak száma folyamatosan változik. Ennek egyrészt oka, hogy a férfiak körében tapasztalható magas arányú szabadságvesztés miatt a nők és a gyermekek a nagyszülőkhöz kerülnek, hiszen a közösség - a nőktől elvárt tradicionális szerepek miatt - általában kitaszítja a gyermekét egyedül nevelő asszonyt ${ }^{33}$. A háztartásméret változásának másik jellemző oka a lakbérhátralék miatt történő - más szolnoki önkormányzati lakásból történő kiköltöztetés, melynek következtében a családok a telepen élő rokonaikhoz költöznek (MTA 2004).

akik az építőanyagokat és a lakás tartozékait értékesítették, vagy beépítették. Ennek hatására az önkormányzat a kiköltözés, vagy kiköltöztetés után a nyílászárók helyét téglákkal falaztatja be, amely megakadályozza a környék lakosait ezen ingatlanokba való bejutását.

${ }^{32}$ A kutatási területemet jelentő Törteli úti szegregátumban a népszámlálási adatok alapján 86 fö élt 2011ben, amely Szolnok lakosságának 0,1\%-át jelentette

33 Ezen jelenség az MTA 2004-es kutatása óta megváltozott, hiszen kutatásom adatfelvételének időpontjában (2016. szeptember) több, gyermekeit egyedül nevelő nő is bekerült a lekérdezett személyek közé. 


\subsubsection{A szegregátum társadalmi hierarchiája}

Az MTA (2004) kutatóinak megfigyelése szerint a Törteli úti közösségen belüli ranglétrát általában az egyének számára rendelkezésre álló pénz és a fizikai erő határozza meg. Ezért a telepen azok az egyedülálló férfiak állnak a hierarchia legalsó szintjén, akik nem rendelkeznek gyökerekkel, vagy börtönviseltek, vagy jelentős adósságot halmoztak fel. Öket a telep valamely prominens családja fogadja be, majd lakhatásért cserébe alantas munkákra kényszerítik. A telep szlengje szerint ők a „csicskások” (MTA 2004).

A szegregátumot két család vonta hatalma alá ${ }^{34}$. Az egyik a telepiek uzsorakamatos hitelezője, a másik pedig - gyermekeiket a verőlegényként alkalmazva - „védelmi” feladatokat lát el. A két család a müködését tekintve kooperál egymással, és tevékenységük a telepen kívülre is kiterjed. Amennyiben a kölcsönt igénylök a 200300\%-os uzsorakamatra felvett pénzt nem tudják visszafizetni, a hitelező család a tartozás miatt az adósok családtagjait vagy elrabolja, vagy prostitúcióra kényszeríti. Emellett a szociális juttatások is azonnal a hitelezőkhöz kerülnek, de kilakoltatás esetén is ezek a családok tárgyalnak a hatóságokkal (MTA 2004). Az „uralkodó” családok a fennálló viszonyokat úgy próbálták fenntartani, hogy gyermekeik a telepen élő családok többségébe „,beházasodtak”. Viszont az utóbbi időben némileg csökkent a családok hegemóniája, hiszen a telep lakosságának cseréje folyamatos, és saját gyerekeik új családjával sem élnek vissza a korábbi mértékben. A kábítószer eladás, az uzsorakamatra kölcsönzés és a zsebtolvajlás viszont továbbra is kiemelt megélhetési módnak számít esetükben (MTA 2004) ${ }^{35}$.

\subsubsection{A telepen élök munkaerö-piaci helyzete}

A rendszerváltás előtt a telepre költöztetett munkaképes korú emberek mindegyike rendelkezett állandó munkával, akik többnyire a vendéglátásban (általában zenészként), a városi kertészetben, vagy az állami vállalatoknál - dohányfermentáló üzem, útépítő vállalat, betongyár, vasút - tudtak elhelyezkedni. A rendszerváltást követően viszont a telepen élő emberek többségének munkát adó üzemek vagy megszüntek, vagy a privatizáció következményeként jelentkező leépítések hatására (CSATÁRI 2018) váltak munkanélkülivé és szorultak ki teljesen a munkaerőpiacról.

\footnotetext{
${ }^{34}$ Az említett helyzet az MTA kutatás óta eltelt időszakban annyiban változott, hogy már csak egy család tölt be ilyen jellegü, meghatározott szerepet a telepen élők mindennapjaiban

35 A 2004-es az MTA kutatói által a telepen végzett kutatás óta - interjúalanyaim szerint - a szegregátumban megfigyelhető kábítószerfogyasztás mértéke emelkedett, az uzsorakamatra történő kölcsönzés továbbra is jelen van és a prostitúció, mint a létfenntartás egyik módja szintén megfigyelhető.
} 
A 2011-es népszámlálási adatok egyértelmüen mutatják a telepen élők munkaerőpiaci integráltságának hiányát: a szolnoki aktív korúak (48.403 fö) 3,4\%-a (1636fö) volt álláskeresőként nyilvántartva, a Törteli és Motor utcai kiterjedt telepen élő munkaképes korú lakosság (50 fö) körében ez az arány 96\%-ot (48 fö) mutatott (SZMJVÖ 2013). Emellett a rendszeres munkajövedelemmel nem rendelkezök aktív korúak aránya $76 \%$ felett volt, míg a városi mutató 36,2\%-ot jelzett (SZVF 2017).

A magas munkanélküliség figyelemre méltó összefüggést mutat az iskolai végzettség alacsony szintjével. Az aktív korú szolnoki lakosságon belül mindössze 5,9\% azok aránya, akik nem rendelkeznek rendszeres munkajövedelemmel és legfeljebb általános iskolai végzettséget szereztek, míg a kiterjedt telepen élők között ez az arány 96\% (48 fö) (SZMJVÖ 2013). A 2011-es népszámlálás eredményei szerint a Törteli úti szegregátumban élő aktív korúak között sokkal magasabb volt munkanélküliség, mint Szolnok teljes munkaképes lakosságának körében, és ebből következően jóval nagyobb mértékben jutottak szociális- és foglalkoztatáspolitikai támogatásokhoz is (8. táblázat). A Törteli úti szegregátumban élők 97,2\%-a legfeljebb 8 általános, vagy annál kevesebb iskolai végzettséggel rendelkezik (SZMJVÖ 2013) ${ }^{36}$, jelentős részük elsődleges-, vagy funkcionális analfabéta (MTA 2004).

8. táblázat - A telepen élők munkaerő-piaci integráltsága a 2011-es népszámlálási adatok alapján

\begin{tabular}{|l|c|c|}
\hline & $\begin{array}{c}\text { Szolnoki aktív korú } \\
\text { lakosságon belül }\end{array}$ & $\begin{array}{c}\text { Törteli és Motor úti } \\
\text { szegregátumban élö aktív } \\
\text { korú lakosságon belül }\end{array}$ \\
\hline Nyilvántartott álláskeresök aránya & $3,6 \%$ & $96 \%$ \\
\hline $\begin{array}{l}\text { Rendszeres munkajövedelemmel } \\
\text { nem rendelkezök aránya }\end{array}$ & $36,2 \%$ & $76 \%$ \\
\hline $\begin{array}{l}\text { Rendszeres szociális segélyben } \\
\text { részesülök aránya }\end{array}$ & $0,5 \%(235$ fö) & $8 \%(4$ fö) \\
\hline $\begin{array}{l}\text { Foglalkoztatást helyettesítö } \\
\text { támogatásban részesülök aránya }\end{array}$ & $3,9 \%(1915$ fö) & $52 \%$ (26 fö) \\
\hline
\end{tabular}

Forrás: SZVF 2017, SZMJVÖ 2013, MTA 2004

A rendszerváltás óta a Törteli úti telepen élő emberek közül csak nagyon kevesen tudtak tartós - 6 hónapnál hosszabb - munkaviszonyt szerezni, hiszen a szakmai gyakorlat hiánya, és a képesítés nélküli alacsony iskolai végzettség jelentősen megnehezíti a szegregátumban élő emberek munkaerő-piaci elhelyezkedésének esélyeit: az MTA 2004-es kutatása szerint a Törteli úti telepen élők körében csaknem teljes volt a munkanélküliség, az aktív korúak mindössze 4,8\%-a rendelkezett rendszeres

\footnotetext{
${ }^{36}$ A telepen élő aktív korúak felsőfokú végzettséget nem szereztek, viszont kifejezetten magas arányban rendelkeznek betanító jellegü szakmai ismeretekkel és OKJ szakképesítéssel (SZMJVÖ 2013).
} 
munkajövedelemmel $^{37}$, amely jelzi, hogy az elsődleges munkaerőpiacról teljesen kiszorultak. A mélyszegénység miatt többségük megélhetési bünözéssel próbálta túlélni a mindennapokat, amelyhez a telepen élő gyerekek egy része is igazodott, akiket csoportos koldulás, rablás, lopás, vagy „vasazás” miatt a gyermekjóléti szolgálat védelembe vett. Ezen tevékenységekből származó bevételre a családnak szüksége van, ezért a szülők nem gátolják meg gyermekük ilyen jellegü cselekedeteit (MTA 2004). Emellett a családok szinte kizárólag szociális transzferjövedelmekből és az alternatív munkaerőpiacon végzett alkalmi munkákból tartották fenn magukat. Ez a férfiaknál többnyire a „vasazást” jelentett, a nők esetében pedig idényjellegü, mezőgazdasági munkák voltak jellemzők (MTA 2004). Az így szerezhető alkalmi munkajövedelem viszont magasabb munkabért nyújt a közmunkaprogram által kínált keresetnél, és az ezzel járó rugalmas időbeosztással együtt a közfoglalkoztatás alternatívájánál kedvezőbb lehetőséghez tudnak jutni. Azok a telepen élők, akik az elsődleges munkaerőpiacon el tudtak helyezkedni, általában üzemekben, gyárakban szalagmunkát végeztek, de tartós beilleszkedésre sajnos egyetlen esetben sem került sor, szerződésük többnyire 1-3 hónapon belül megszünt. Ebből adódóan nem meglepő, hogy - a jelenleg elérhető legutóbbi hivatalos adatok szerint - Szolnokon belül az egy före jutó legalacsonyabb jövedelem (37.079 Ft) is a Törteli út mentén figyelhető meg (SZMJVÖ 2013) ${ }^{38}$.

Az önkormányzat szerint a Törteli úti telepen élők munkaképességének fokozása felnőttoktatással megvalósítható, és képzettségi szintjük emelésével Szolnok területi különbségei is enyhíthetők ${ }^{39}$ (SZMJVÖ 2014A). A szegregátum lakóinak munkaerő-piaci esélyei rendkívül beszűkültek, ezért alapvetően a szociális ellátórendszer juttatásaira rendezkedtek be. Szolnok MJV Polgármesteri Hivatal Humán Igazgatóságának helyzetértékelő tanulmánya szerint a területen élők többsége egy deviáns szubkultúrát képvisel, akiknek életstílusa a mélyszegénység társadalmi viszonyaihoz alkalmazkodott: „, a területen felnövö kiskorúak egy erkölcsi veszélyzónában élnek, mely egyértelmüen a szegénység átörökitésének és bünelkövetői utánpótlás kialakulásának kedvez” (TKKI 2011 p. 4).

\footnotetext{
${ }^{37}$ A 2011-es népszámlálási adatok valamivel kedvezőbb képet mutatnak, igaz, ezen számok figyelembe veszik a környéken élök jellemzőit is, amely alapján az aktív korú népesség 22,4\%-a rendelkezik rendszeres munkajövedelemmel, miközben a teljes szolnoki lakosságot figyelembe véve 63,8\% ez az arány. A legfeljebb általános iskolát végzett szolnokiak esetében 93\%, a Törteli út környékén élők körében pedig 40,8\% ez az arány (SZMJVÖ 2014A).

${ }_{38}$ A lentebb kifejtett kutatási eredményeim jelzik, hogy a legutolsó felmérés óta a telepen élők átlagos jövedelmi szintje csökkentést mutat.

${ }^{39}$ A TÁMOP 5.3.6 11/1 Komplex telep-program keretében azok a telepen élőknek, akik már legalább 6 általános iskolai osztállyal rendelkeztek, egy 6 hónapos, akkreditált képzés során lehetőségük nyílt befejezni az általános iskolai tanulmányaikat. Emellett a férfiak építőipari képzésen, a nők pedig parkgondozó és háztartási ismereteket oktató tanfolyamokon vehettek részt.
} 


\section{A kutatás módszertani alapjai}

A disszertáció alapjául szolgáló vizsgálat során mind a Tiszabőn, mind pedig a szolnoki szegregátumban élő célcsoport részéről nyitottságot tapasztaltam. A kérdőívek kitöltése legtöbb esetben az ingatlanokban történt, ritkábban a kertben, esetenként pedig a ház előtti utcafronton. A kutatási mintába került háztartásokat a 2016. augusztus és szeptember közötti adatfelvétel során hétköznaponként, az átlagos munkaidő vége után 16.30-tól, hétvégenként (általában vasárnap) pedig 14.00 óra utáni időpontokban kerestük fel.

Mivel a településen található egyes házakban, lakásokban élő emberekről nem feltételezhető, hogy egy családot alkotnak, ezért kutatásom alapegységét a háztartások jelentették, amelyek a mintavétel szempontjából kézzelfogható, megragadható egységet alkotnak. A Tiszabőn és a Törteli úti szegregátumban élő háztartásokat az ott található egyes ingatlanok alapján különítettem el. Eszerint egy háztartásba tartozónak azon személyeket tekintettem, akik - rokoni kapcsolatuktól függetlenül - egy házban, vagy lakásban élnek, jövedelmi és fogyasztói közösséget képeznek, valamint a létfenntartás (étkezések, napi kiadások, stb.) és folyamatos életviteli költségeket részben, vagy egészben megosztják, közösen viselik (SMF 2006).

Az adatgyüjtéshez szükséges, és a mintavétel alapjául szolgáló ingatlanok kiválasztásának előzetes megtervezését a térképem.hu adatbázisának használatával végeztem, amely szerint Tiszabő lakásállománya összesen 634 ingatlanból áll, míg a szolnoki Törteli úti szegregátum területére 31 lakást jelez. Az adatfelvételt megelőző terepfelmérés egyértelművé tette, hogy mindkét mintaterületen - különböző okoknál fogva - jóval kevesebb lakóingatlan található ${ }^{40}$, így a kutatáshoz alkalmazott végleges minta kiválasztásához a saját terepbejárásaim által feljegyzett ingatlanszámokat vettem alapul. Terepfelméréseim alapján Tiszabő lakásállományát mintegy 420 épületet alkotja, míg a Törteli úti telepen pontosan 16 lakás található ${ }^{41}$. Mivel a háztartások tagjainak pontos számát a rokonok folyamatos ki- és beköltözése miatt nehéz megállapítani, ezért a kutatás során az adatfelvétel időpontjában a lakásban együtt élők számát jegyeztem fel.

\footnotetext{
40 Tiszabő lakásállományának előzetes összeírásához használt oldal feltehetően a 2000-es árvíz okozta változások (részletesebben lásd: 43. oldal) elötti ingatlanszámot vette figyelembe, míg a Törteli úti szegregátumhoz kapcsolódó adatoknál a telep folyamatosan csökkenő lakásszámának (részletesebben lásd: 50. és 52. oldal) változásait nem követte nyomon.

${ }^{41}$ A szolnoki szegregátumhoz kapcsolódó kutatás esetszáma a településrész méretéből adódóan jóval kevesebb, mint a tiszabői kutatás során felvett kérdőív, ezért a telepi kutatás relevanciája alacsonyabbnak tünhet. Ennek kiegyensúlyozására a szolnoki Törteli úti telep esetében az eredmények hitelességét a teljes lekérdezés biztosította.
} 


\subsection{Adatfelvételhez alkalmazott módszerek}

A kutatási minta összeállításánál a legfontosabb célom volt, hogy annak összesített jellemzői minél jobban megközelítsék a mintaterületek teljes populációinak tulajdonságait. Ennek érdekében a lakossági, kérdöives adatfelvétel reprezentativitásának biztosításához mindkét mintaterületen olyan valószínüségi mintavételt alkalmaztam, amely eljárások használatával minden háztartásnak ugyanakkora esélye volt a vizsgálati mintába kerülésre. Tiszabő esetében a település alaprajza és ingatlanállománya alapján készített területileg arányosan rétegzett szisztematikus mintavételt használtam, amely szerint a település lakásállományának minden negyedik elemét válogattam a mintába. A megfelelő területi eloszlás érdekében a mintavételt a település minden utcájára elkészítettem, amely egyben a rétegzés szempontjait is jelentette. Ennek eredményeként a mintavételi intervallum ${ }^{42} 4$-et, míg a minta kiválasztási aránya ${ }^{43}$ 1/4-et mutatott. A szolnoki Törteli úti szegregátum esetében a reprezentativitást a teljes lekérdezés biztosította, amely esetben csökkenö mintás eljárást alkalmaztam. Az elért háztartásokban a háztartásfők válaszoltak a kérdésekre. Az eredetileg meghatározott 100 tiszabői háztartásból álló mintanagyság megőrzése érdekében esetenként pótmintaelemeket is kellett használni, amelyeket a föcímek kiesésekor vettem igénybe. Mindössze néhány háztartásvezető jelezte, hogy nem kíván válaszolni kérdéseinkre, így a válaszmegtagadás aránya minimális, 15\% volt. A pótcímek esetében a főcím melletti - növekvő számsorrendet figyelembe véve ingatlanban élö háztartás került lekérdezésre.

A kutatás megfigyelési egységét a háztartásfők jelentették, míg az elemzési egységet az egyes háztartások tagjai alkotják, akik elsősorban a demográfiai kérdéseknél biztosítottak számunkra információkat a velük együtt elő háztartástagokról. Ennek eredményként 103 tiszabői és 16 Törteli úti telepen élő háztartásfő került lekérdezésre kérdőívvel, amelynek folyamán 576 Tiszabőn, és 79 Szolnokon élő hátrányos helyzetü személyről sikerült információt gyüjteni. A válaszadók segítségével Tiszabőn összesen 354 aktív korú, míg Szolnokon 50 munkaképes korban lévő személyről tudtunk adatot nyerni. Ugyanakkor a Tiszabőn élők munkaerő-piaci helyzetét kizárólag azon 245 fő aktív korú falubeli adatai alapján jellemzem, akik élethelyzetükből adódóan is képesek a munkavégzésre, tehát a kutatás idején nem folytattak nappali tagozatos tanulmányokat, illetve gyermekvállalás nem hátráltatta a munkavállalás lehetőségét. Ez a szám a szolnoki

\footnotetext{
${ }^{42}$ Mintavételi intervallum: populáció elemszáma/minta elemszáma (BABBIE 2003)

${ }^{43}$ Kiválasztási arány: minta elemszáma/populáció elemszáma (BABBIE 2003)
} 
Törteli úti szegregátumban élők esetében 37 fő. A szenzitív és egyéni választ igénylő témák természetesen kizárólag a háztartásfők, vagyis a kérdőív alanyainak válaszai alapján lettek leírva.

Az adatfelvétel módszereinek kiválasztása során igyekeztem figyelembe venni a mintaterületeken végzett korábbi kutatásaim tapasztalatait, ezért - a kérdések pontos értelmezhetősége miatt - a kérdőívek minden esetben kérdezőbiztossal lettek felvéve. A strukturált kérdőív (Melléklet 2.) négy részből - 1. Demográfiai adatok; 2. Jelenleg az elsődleges munkaerőpiacon alkalmazásban álló aktívak ${ }^{44}$ kérdései; 3 . Munkaerő-piaci szempontból aktív korú, elsődleges munkaerő-piaci szempontból inaktívak ${ }^{45}$ kérdései; 4. Közmunkaprogramban résztvevők kérdései - állt. A kérdőív felvétele során az első demográfiai - rész utolsó (21.) kérdése után, választól függően lettek kitöltve a kérdőív további moduljai. Ezek alapján, akik teljes, vagy részmunkaidőben bejelentett munkát végeznek, illetve a bejelentett munka mellett mellékfoglalkozást is vállalnak, vagy saját vállalkozásukban dolgoznak, ők az első, demográfiai modul után a második részt töltötték ki. Akik a kutatás idejében a 21. kérdés szerint a közmunkaprogramban dolgoztak, álláskeresési támogatást kaptak, vagy aktív korúak ellátására (foglalkoztatást helyettesítő támogatásra, vagy egészségkárosodási és gyermekfelügyeleti támogatásra) jogosultak, esetleg alkalmi munkákat - eseti megbízás, vagy megbízás nélküli napszámos tevékenység - végeztek, ők a harmadik és a negyedik rész kérdéseire válaszoltak, míg a nem hivatalos, feketemunkát végzők a második és a negyedik modult töltötték ki. A tanulók, a nyugdíjasok és azok, akik a kutatás idejében gyes-en, gyed-en, gyet-en voltak, ők kizárólag a demográfiai kérdésekre válaszoltak. Az adatfelvételt személyemen kívül - egy, esetenként két kérdezőbiztos segítette.

Mivel a kvantitatív kutatási adataim kérdezőbiztos által lekérdezett strukturált kérdőívek segítségével lettek felvéve, a kérdéssorok kitöltése közben sok esetben

\footnotetext{
${ }^{44}$ A dolgozatban az elsődleges munkaerőpiacon ${ }^{44}$ aktív személyeknek azon a 15 és 64 év közötti tiszabői és Törteli úti szegregátumban élő munkavállalókat tekintettem, akik szerződéses jogviszonyban - teljes, vagy részmunkaidőben - a nyílt munkaerőpiacon helyezkedtek el, vagy egy primer munkaerö-piaci pozícióban, munkaszerződés nélküli feketemunkát végeznek, esetleg mellékfoglalkozásban, vagy saját vállalkozásukban dolgoznak.

45 Elsődleges munkaerő-piaci szempontból inaktívaknak tekintem azokat a 15 és 64 év közötti tiszabőieket és Törteli úti szegregátumban élőket, akik a kutatás időpontjában már befejezték tanulmányaikat, nem kaptak családtámogatási juttatást (gyes, gyed, gyet), és nem folytattak állandó, folyamatos keresőtevékenységet a nyílt munkaerőpiacon. E csoportba tartozó emberek a kutatás időpontjában vagy a másodlagos munkaerőpiacon a közmunkaprogramban dolgoztak, vagy álláskeresési támogatást kaptak, vagy aktív korúak ellátására (foglalkoztatást helyettesítő támogatásra, vagy egészségkárosodási és gyermekfelügyeleti támogatásra) voltak jogosultak, esetleg alkalmi munkákat eseti megbízást, vagy megbízás nélküli napszámos tevékenységet - végeztek. Emellett ebbe a csoportba tartoztak azok a 15 és 64 év közöttiek is, akiknek nem volt munkájuk, sem bevételük, nem tanultak, tehát aktív korú eltartottak voltak.
} 
alakultak ki kötetlen beszélgetések, strukturálatlan interjúk, amelyek szisztematikus lejegyzéseiből nyert kvalitatív adatok jelentettek kiegészítő információt a kutatási eredményekhez. Ezen információközlések többsége a helyi, környéki - elsődleges- és másodlagos - munkaerő-piaci helyzetre, politikai viszonyokra és a jövedelemszerzési lehetőségekre fókuszált, valamint a lokális összefüggések megértését tették lehetővé.

A kutatás során - szakértői kiválasztással - tizennégy, Tiszabőn élő olyan hátrányos helyzetű személyekkel készítettem félig strukturált interjút, akik a kérdőív felvétele során egyrészt az átlagosnál nyitottabb hozzáállást mutattak, másrészt az adatfelvétel közben kialakult beszélgetések alkalmával mélyebb információkat osztottak meg a település mindennapjairól és az itt élők helyzetéről, lehetőségeiről. Emellett a faluban élő, korábban a tiszabői családsegítő központ munkatársaként dolgozó, a kutatás időpontjában pedig a közmunkaprogram egyik adminisztrátoraként tevékenykedő emberrel és a kunhegyesi kormányhivatal foglalkoztatási osztályának munkatársával is készült interjú.

A Törteli úti telepen élők az adatfelvétel során jóval zárkózottabb hozzáállást mutattak, ezért a szegregátumban élőkkel nem készült félig strukturált interjú. Ezt a hiányosságot a telepen élőkkel kapcsolatban álló, számukra szociális segítséget nyújtó személyekkel készített interjúkkal igyekeztem helyettesíteni. Az információforrások összeállításánál a legfontosabb célom volt, hogy minél jobban lefedjék azokat az embereket és szervezeteket, akik a közigazgatási, önkormányzati, vagy a szociális oldalról kapcsolatban állnak a telep lakóival. Ennek érdekében a kérdőíves adatfelvételt követően - a családsegítő szolgálattól indult hólabda módszerrel-kilenc félig strukturált interjút készítettem, amely során egy szolnoki családsegítő szervezet vezetőjével, az intézménynél dolgozó két szociális munkással, esetmenedzserrel és a szenvedélybetegségekkel foglalkozó két mentálhigiénés szakemberrel folytattam beszélgetéseket. Emellett a telepen szolgálatot teljesítő polgárörrel és a Törteli úti telepen élökkel foglalkozó egyesület közösségfejlesztőivel és egy korábbi telep-program projektkoordinátorával készítettem interjút. A félig strukturált interjúk során mindkét mintaterületen reflexív szemlélettel közelítettem a beszélgetés során érintett témákhoz, vagyis a kérdőíves adatfelvétel egyes eredményeit beépítettem az interjúvázlatba (Melléklet 3.).

A két területen folytatott, valamelyest eltérő - félig strukturált interjús - módszer némi szemléletbeli különbséget eredményezett, hiszen míg Tiszabőn a helyi lakosok meglátásaira hagyatkoztam, addig a szolnoki telepen élők esetében szakértők véleményeire, álláspontjaira támaszkodtam. A félig strukturált interjúk elsősorban a 
mintaterületeken élők körülményeire, elhelyezkedési és jövedelemszerzési lehetőségeire, valamint a munkaerőpiaccal kapcsolatos szándékaira keresték a választ.

A Tiszabőn eltöltött idő - körülbelül 35 nap -, és a Törteli úti telepen tett látogatásaim - körülbelül 20 alkalom - során résztvevő megfigyeléssel is lehetőségem nyílt bepillantást nyerni a település és a szegregátum mindennapi életébe, rálátni a közmunkaprogramban dolgozó emberek feladataira, és a különböző kiegészítő elsősorban illegális, nem hivatalos - munkatevékenységekre. A résztvevő megfigyelés során tapasztaltak esetében különösen figyeltem, hogy az események dokumentációi személyes információkat ne tartalmazzanak.

A disszertációban több olyan vélemény, állásfoglalás is leírásra került, ami néhány érintettnek kompromitáló lehet. Ezért jelzem, hogy a dolgozatban leírt egyes megállapítások a kutatás során feltárt vélemények, és beszámolók alapján készültek és nem bizonyított tényeket fednek. Az interjúalanyokat érhető esetleges későbbi következmények, hátrányok elkerülése érdekében a személyazonosságuk felismerhetőségére lehetőséget nyújtó információkat megváltoztattam.

$\mathrm{Az}$ elsődleges, terepi adatfelvételt megelőző másodelemzés során a népszámlálások adatait (KSH 2001, 2013, 2015 2016C), valamint korábbi, Tiszabőn végzett (SEBESTYÉn 2002, TóTH et al. 2012, ZOLNAY 2012, SZEGÖ 2010) és a Törteli úti szegregátumhoz kapcsolódó (MTA 2004, SZARVÁK 2007, SZVF 2017, SZMJVÖ 2006, 2013, 2014A, 2014B, TKKI 2011) kutatások eredményeinek elemzését használtam fel.

\subsection{Elemzéshez használt módszerek}

A demográfiai adatok elemzéséhez elsősorban gyakorisági eloszlást ${ }^{46}$ használtam, majd a munkaképes korúak között a munkaerőpiachoz való viszonyulás alapján $a$ változók összevonásával, aggregálásával három csoportot hoztam létre. Az első csoportba tartoztak azok az aktív korúak, akik a kutatás időpontjában a nyílt munkaerőpiacon - teljes, vagy részmunkaidőben, hivatalosan, vagy munkaszerződés nélkül - állandó munkát végeztek. A második csoportba azok a nappali tagozatos tanulmányokat nem folytató munkaképes korú, de az elsődleges munkaeröpiac szempontjából inaktívak kerültek, akik az adatfelvétel idején a közmunkaprogramban dolgoztak, vagy álláskeresési támogatásra, illetve aktív korúak ellátására voltak

\footnotetext{
${ }^{46}$ A gyakorisági eloszlás egy olyan statisztikai mutatószám, amely jelzi, hogy a minta elemei az összes elemszámhoz képest milyen mértékben oszlanak meg a különböző csoportok között, vagyis megmutatja az értékek mintabeli előfordulásának arányát.
} 
jogosultak, esetleg alkalmi munkákat végeztek, de azok a személyek is e csoportba kerületek, akik semmilyen bevétellel nem rendelkeztek. A harmadik csoportba kizárólag az állam által támogatott másodlagos munkaerőpiacon elhelyezkedők, vagyis a közmunkaprogram dolgozói kerültek, tehát ezen aggregátum a második csoport egy alcsoportját képezi. Így a következő három nagy, egymással összehasonlítható csoportot alakítottam ki: nyílt munkaerőpiacon elhelyezkedők (elsődleges munkaeröpiacon aktívak); a nyílt munkaerőpiac szempontjából inaktívak (elsődleges munkaeröpiacon inaktívak); közmunkaprogramban dolgozók (közfoglalkoztatottak).

A csoportok létrehozását követően az egyes tulajdonságokat gyakorisági eloszlással elemeztem, majd a fontosabb munkaerő-piaci jellemvonások közötti összefüggéseket kereszttábla-elemzéssel ${ }^{47}$ vizsgáltam.

\section{A mintaterületeken végzett kutatás eredményei}

A következő fejezetben a dolgozatomhoz kapcsolódó, terepen végzett kutatás eredményeit mutatom be, kezdve a rurális jellegü periférikus térségek falvait reprezentáló Tiszabőn élők demográfiai jellemzőivel, munkaerő-piaci helyzetével, és jövedelmi viszonyaival. Majd a falu földrajzi- és infrastrukturális sajátosságainak bemutatásával folytatom, később áttérek a szegénység kultúrájának területi megjelenésére. Ezután a területi stigma hatásait mutatom be, végül pedig a közmunkaprogram hatásait, eredményeit ismertetem. A fejezet második felében a centrumhoz közeli, városi periféria mintaterületeként szolgáló Törteli úti szegregátum és az ott élők hasonló szempontok szerinti körülményeit szemléltetem a terepen kapott eredmények tükrében.

5.1. Tiszabő demográfiája, a faluban élők iskolai végzettsége és jövedelmi helyzete a munkaerő-piaci szerepvállalás aspektusából

A Tiszabőn élők átlagos életkora 24 év, a 18 év alattiak aránya (45,6\%) pedig közel azonos a felnőttkorúakéval $(54,4 \%)$, tehát a falu társadalma az országos tendenciával ellentétben fiatalodó jelleget mutat, ahol a lakosság kétharmada (66,7\%) mondható munkaerő-piaci szempontból aktív korúnak (15-64 év). A községben élő teljes lakosság 36,2\%-a gyermekkorú (0-14 év) és mindössze az ott élök 2\%-a lépte át a

\footnotetext{
${ }^{47}$ A kereszttábla-elemzést két nominális, vagy ordinális változó kapcsolatának vizsgálatára használjuk.
} 
nyugdíjkorhatárt. A tiszabői átlagos háztartásméret hat főből $(5,59)$ áll, amely minden negyedik háztartásra jellemző. A tiszabőiek iskolai végzettségei igen alacsonynak mondhatók; a már befejezett tanulmányokkal rendelkező ${ }^{48}$ helyiek kiemelkedő többsége ugyan rendelkezik általános iskolai végzettséggel, viszont a falubeliek közel hetede nem végezte el az alapfokú oktatást ${ }^{49}$. Szakmunkásképző bizonyítványt csak alacsony arányban szereztek és a lakosok minimális része érettségizett, felsőfokú végzettséggel pedig ennél is kevesebben rendelkeznek.

9. táblázat - A tiszaböiek legmagasabb iskolai végzettsége a befejezett tanulmányokkal rendelkezök körében (N=307)

\begin{tabular}{|l|c|}
\hline Nem járt iskolába & $1,6 \%$ \\
\hline 8 általánosnál kevesebb iskolai végzettség & $13,7 \%$ \\
\hline 8 általános iskolai végzettség & $62,2 \%$ \\
\hline Szakmunkásképzö bizonyítvány & $14,7 \%$ \\
\hline Szakiskolai oklevél & $2,6 \%$ \\
\hline Érettségi bizonyítvány & $3,6 \%$ \\
\hline Érettségire épülő szakképesítés & $1 \%$ \\
\hline Felsőfokú szakképesítés & $0,3 \%$ \\
\hline Föiskolai, vagy BA diploma & $0,3 \%$ \\
\hline
\end{tabular}

Egyetemi képzettséggel rendelkező személy nem él Tiszabőn, és az értelmiségiek aránya is minimálisnak mondható. Viszont a falu lakosságának 26\%-a szerzett szakmai képesítést iskolai keretek között, vagy tanfolyamon keresztül. Ezek között a leggyakoribb a hegesztő (10\%), a mezőgazdasági állattenyésztő (6\%), a növénytermesztő gépész és a varrónő (5-5\%) képzettség. A tiszabői háztartásokban átlagosan két fő 15 év feletti, befejezett tanulmányokkal rendelkező személynek van rendszeres havi jövedelme vagy önálló keresete (fizetés, szociális juttatás, nyugdíj, stb.). A háztartások 5,8\%-ában viszont egyetlen személynek sincs jövedelme, míg a legtöbb, jövedelemmel rendelkező személy egy háztartáson belül hat fő volt $(1,9 \%)$.

A faluban élők jövedelemforrásának meghatározó részét jelenti a közmunkaprogramból származó fizetés, hiszen a háztartások 81,4\%-ában legalább egy fö közfoglalkoztatottként dolgozik. Ezzel szemben az együttélések mindössze 21,6\%ában található olyan személy, aki állandó és bejelentett munkával rendelkezik. Tehát a háztartások 78,4\%-ában egyetlen embernek sincs állandó - nem a közmunkaprogramhoz

\footnotetext{
${ }^{48}$ A falubeliek iskolai végzettségének vizsgálatakor figyelembe vettem a folyamatban lévő tanulmányokat, ezért az ő esetükben nem számítottam befejezett iskolai végzettséggel, hiszen a fiatal korosztály magas aránya jelentősen torzította volna a mintát a 8 általánosnál kevesebb végzettséggel rendelkezők irányába, amelyet jelez a folyamatban lévő tanulmányokat folytatók magas aránya. A kutatás időpontjában a tiszabőiek 41,7\%-a folytatott nappali tagozatos tanulmányokat, tehát $58,3 \%$ fejezte be iskolai tevékenységeit.

${ }^{49}$ Akik nem fejezték be az általános iskolát, átlagosan hat osztályt végeztek el.
} 
köthető - munkahelye. A közfoglalkoztatásban való részvétel miatt a háztartások többségében $(78,4 \%)$ nem jogosultak szociális juttatásra: 20,6\%-nál egy fó, míg 1\%-nál két személy kap szociális támogatásokat.

A tiszabői háztartások átlagosan havi nettó 167.340 Ft-ból gazdálkodnak, amelyet ha elosztunk a hat fős $(5,59)$ átlagos háztartásmérettel, akkor láthatjuk, hogy egy tiszabői lakos 29.936 Ft-tal tud számolni, ami pontosan 1.436 Ft-tal magasabb a szegénységi küszö $b^{50}$ egyik meghatározott objektív határánál, vagyis nyugdíjminimum 28.500 Ft-os összegénél, de mindössze 42,5\%-a az EU tagállamaiban elfogadott értéknek, amely a társadalom mediánjövedelmének $60 \%$-át veszi alapul. A Tiszabőn mérhető egy főre jutó átlagos jövedelem csupán 41,6\%-a a létminimum 71.800 Ft-os értékének ${ }^{51}$. Az élelmiszerfogyasztás normatív értékéből kiinduló létminimum-számítás alapján a tiszabőiek egy főre jutó jövedelme a 2016-os évre számított létfenntartás minimális összegének (88.619 Ft) mindössze egyharmadát (33,7\%) éri el.

Az eredmények alapján egyértelmüen kijelenthető, hogy a falu egész lakossága mélyen a számított szegénységi érték határa alatt él, ahol az egy aktív korúra számított nettó jövedelem 55.227 Ft. Az összeg nem meglepő, hiszen a községben élő emberek elsőszámú foglalkoztatója az önkormányzat, amelyet jól mutat, hogy az összes falubeli közül minden negyedik tiszaböi (25\%) a közmunkaprogramban dolgozik és csak 4,5\%uknak van teljes munkaidejü, bejelentett állása az elsődleges munkaerőpiacon. Alkalmi munkavégzésből a falubeliek 9,2\%-a él, míg gyes-t, gyed-et, vagy gyet-et 5,3\%-uk kap, a helyiek 4,3\%-a pedig nyugdíjas ${ }^{52}$. A tiszabőiek minimálisnak mondható 3\%-a tartja fenn magát álláskeresési támogatásból, vagy aktív korúak ellátásából (foglalkoztatást helyettesítő támogatás, vagy egészségkárosodási és gyermekfelügyeleti támogatás), és

\footnotetext{
${ }^{50}$ Az Európai Unió tagállamaiban szegénységi küszöbnek az adott ország mediánjövedelmének 60\%-án tekintik. Az így kapott érték alatti jövedelemmel rendelkező háztartásokban élőket tekintik jövedelmi szegényeknek (SIPOSNÉ NÁNDORI 2012). Magyarországon 2013-ban a népesség 14,6\%-a élt a relatív szegénységi küszöb alatt, amely szerint 1,4 millió ember tekinthető relatív jövedelmi szegénynek. A munkanélküliek csoportjában 3,5-szer többen élnek a szegénységi küszöb alatt az országos átlaghoz képest (KSH 2014). A relatív szegénységi küszöb értéke az egyszemélyes háztartásokra értendően $843.941 \mathrm{Ft}$ volt (BÁNFALVI 2016), vagyis havi 70.328 Ft. A szegénységi küszöb meghatározásának egy másik meghatározása szerint ez az érték megfelel az öregségi nyugdíjminimum egy főre jutó értékének (ÉLTETÖHAVASI 2004). Ennek értéke 2016-ban 28.500 Ft volt.

51 A létminimum az az összeg, amely biztosítja a folyamatos életvitelhez nélkülözhetetlen alapvető szükségletek társadalmilag elfogadható szintü kielégítését (KSH 2012). A létminimum értékének kiszámítását az élelmiszer-fogyasztás normatív értékéből kiindulva a háztartások fogyasztási adatainak felhasználásával végzik el (ZAFír 1997). Ennek számításakor az Országos Élelmezés- és Táplálkozástudományi Intézet által kidolgozott élelmiszer-mennyiségeket veszik figyelembe, amelyeket mintegy száz konkrét termékre részletezve tartalmaz a létminimum-számítás élelmiszerkosara. Ezen számítások eredményeként 2016-ban az egy fogyasztási egységre számított létminimum értéke 88.619Ft, a különböző háztartástípusokra érvényes egy före számított érték pedig 71.800 Ft volt (POLICY AGENDA 2017).

52 A nyugdíjasok többsége (62\%) öregségi alapon kap juttatást, míg 5\%-uk özvegységi nyugdíjban részesül, 33\%-uk pedig rokkantsági nyugdíjat kap.
} 
minden negyedik (25\%) falubeli tanulói státuszban van. Az olyan további megélhetési formák, mint a bejelentett munka melletti részállás $(0,5 \%)$, a saját vállalkozás $(0,4 \%)$, valamint a nem hivatalos, vagyis feketemunka $(0,3 \%)$ aránya elhanyagolható mértékü, ellenben a tiszaböiek 6,9\%-a nem tanul, nincs munkája és nincsenek bevételei.

Viszont, ha csak a munkaképes (15-64 év) korúak fő tevékenységét vizsgáljuk, látható, hogy az elsődleges munkaerőpiacon a tiszabőiek 10\%-a helyezkedett el, 15\%-uk tanulmányokat folytat, 9\%-uk gyes, gyed, vagy gyet támogatást kap, közel kétharmaduk (62\%) pedig a nyílt munkaerőpiac szempontjából inaktív. A községben élők 43,2\%-a dolgozik a közmunkaprogramban és $4 \%$-uk - nem öregségi - nyugdíjas.

Ha pedig kizárólag azon tiszabőieket helyezem a vizsgálati körbe, akik életkoruk mellett élethelyzetükből adódóan is képesek munkavégzésre - nem folytatnak tanulmányokat, és nincsenek gyes-en, gyed-en, vagy gyet-en -, akkor látható, hogy a 15 és 64 év közötti falubeliek mindössze 13\%-a tudott elhelyezkedni az elsődleges munkaerőpiacon, míg 87\%-uk nyílt munkaerő-piaci szempontból inaktív. A kutatás időpontjában a munkaképes korú inaktívak többsége - pontosan 68,5\%-a - a másodlagos munkaerőpiacon, vagyis az állam által támogatott közfoglalkoztatásban vett részt. Ez a teljes munkaképes korú tiszabői lakosság 43,2\%-át jelenti, ami jól ábrázolja a falu munkaerö-piaci helyzetét.

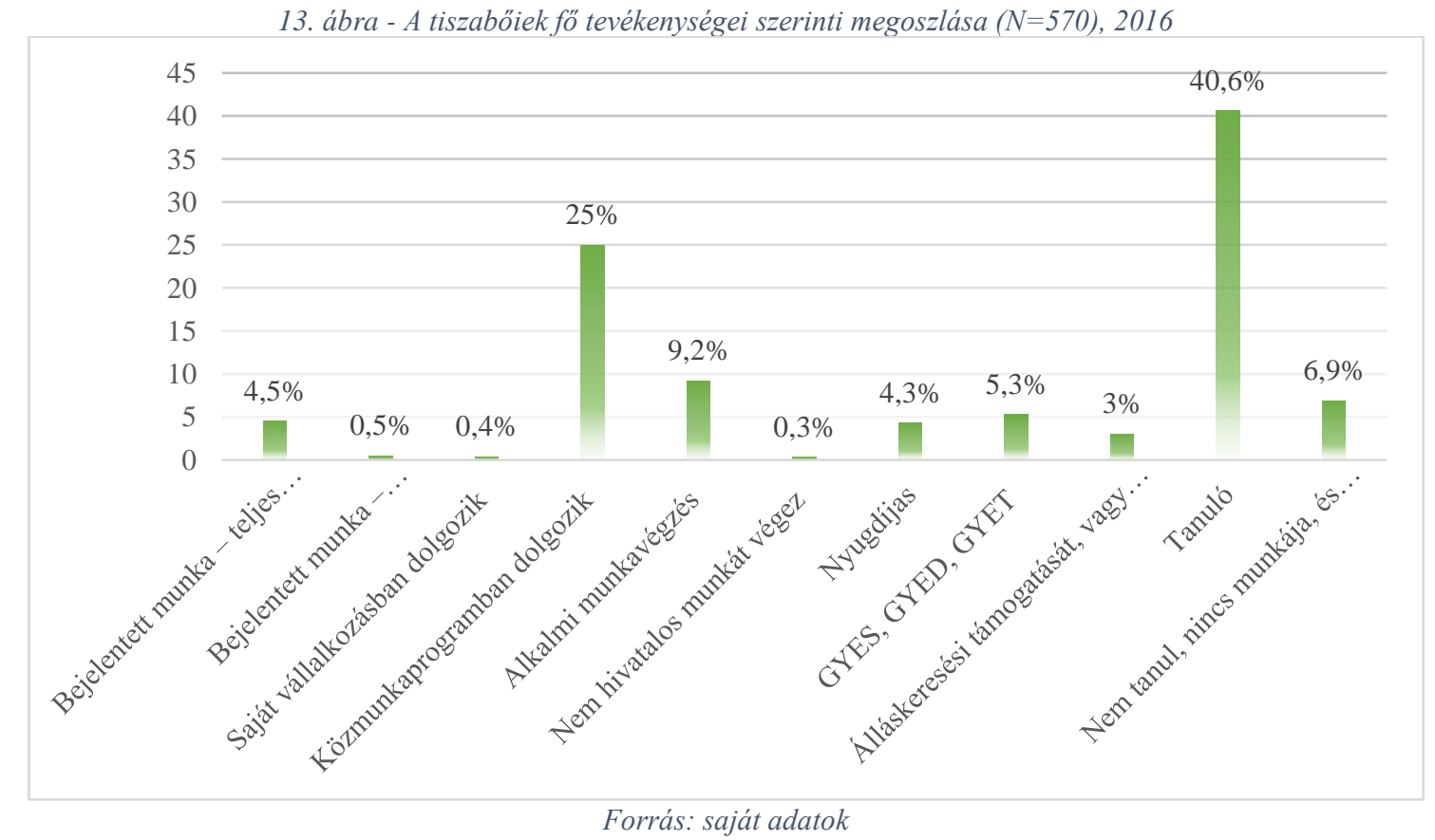

A kutatás eredményeiből egyértelmüen megállapítható, hogy az elsődleges munkaerőpiacon dolgozó aktív korú tiszabőiek jóval fiatalabb életkorban, átlagosan hat évvel korábban (16 év) folytattak először kereső tevékenységet, mint a 15 és 64 év 
közötti, jelenleg inaktív falubeliek (22 év). Ez a jelentős különbség eltérő családi szocializációt is feltételez. Emellett az elsődleges munkaerőpiacon dolgozók két évvel korábban helyezkedtek a nyílt munkaerőpiacon, mint azok, akik - tanulmányuk befejezése ellenére - jelenleg nem folytatnak aktív elsődleges munkaerő-piaci tevékenységet.

A rurális jellegü periférikus területeken élő nyílt munkaerőpiacon aktív és inaktív csoportok között a legjelentősebb különbség iskolai végzettség tekintetében mutatható ki. Az elsődleges munkaeröpiacon elhelyezkedők közül a legtöbben szakmunkásképző iskolát végeztek $(51,5 \%)$, de - a falu iskolázottsági szintjéhez képest ${ }^{53}$ - kifejezetten magas arányban $(18,2 \%)$ vannak közöttük érettségivel rendelkezök, emellett e csoportban mindenki befejezte az általános iskolát. Ezzel szemben az aktív korú, de nyilt munkaerö-piaci szempontból inaktív tiszabőiek elsősorban alapfokú iskolai végzettséget szereztek (68,2\%), csupán 9,7\%-uk végzett szakmunkásképző iskolát és mindössze 2,3\%-uk rendelkezik érettségivel, 17,5\%-uk pedig nem fejezte be az általános iskolát. Az elsődleges munkaerőpiacon inaktív csoporton belül a közfoglalkoztatottak iskolai szintje a legalacsonyabb. Körükben a legmagasabb azok aránya, akik nem fejezték be az általános iskolát (19,2\%), többségük alapfokú végzettséggel rendelkezik (68,9\%), szakmunkásképző iskolát mindössze 7,9\%-uk végzett, érettségit pedig a közmunkások $2 \%$-a szerzett.

14. ábra - Az aktív korú falubeliek iskolai végzettsége munkaerö-piaci aktivitás szemszögéböl (N=245), 2016

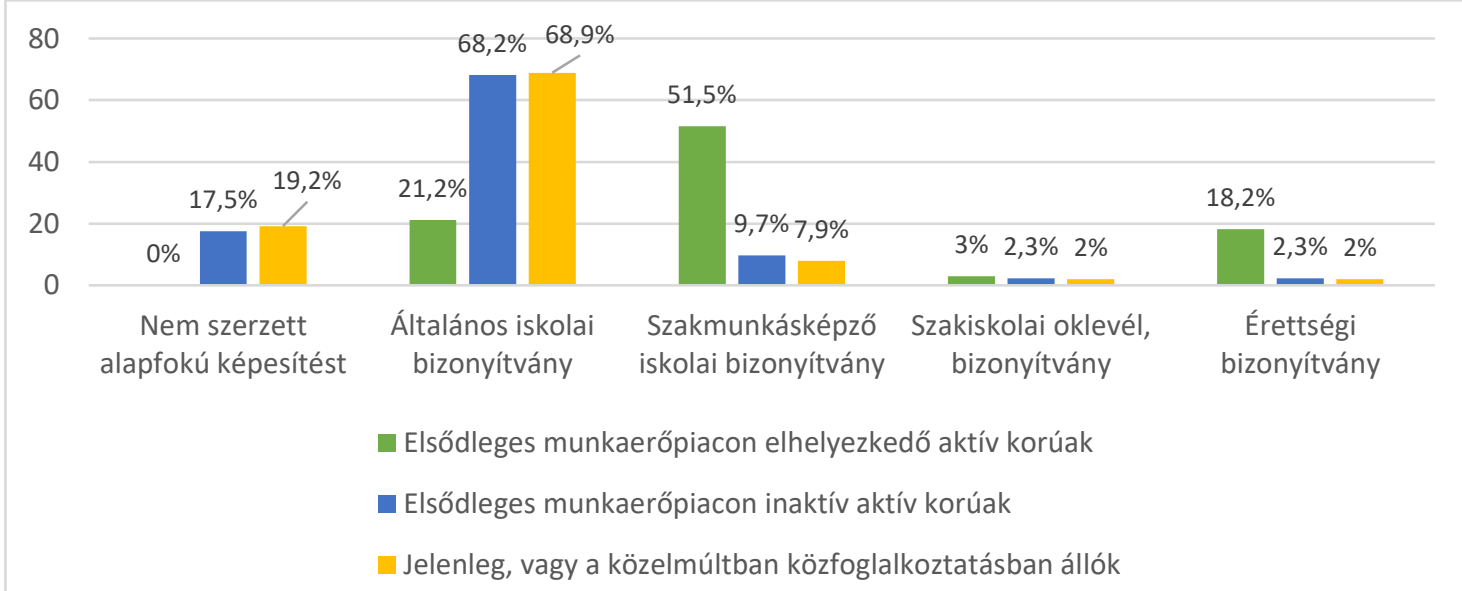

Forrás: saját adatok

A munkahelyi jóllétet, elégedettséget és a nyílt munkaerő-piaci pozíció megbecsülését jelzi, hogy az elsődleges munkaerőpiacon dolgozó tiszabőiek 92,4\%-a szereti jelenlegi munkáját, amelyért átlagosan havonta nettó 127.000 Ft-ot kapnak. Ez a

${ }^{53}$ A befejezett tanulmányokkal rendelkező tiszabőiek 3,6\%-a szerzett érettségit. 
magyar alkalmazásban állók nettó átlagkeresetének (175.009 $\mathrm{Ft}^{54}$ ) 72,5\%-a. A közmunkaprogramban szerzett pozíciójukat ennél alacsonyabb arányban $(71,7 \%)$ kedvelik a falubeliek, ahol - családi kedvezmény nélkül - nettó $51.847 \mathrm{Ft}$ és $73.177 \mathrm{Ft}$ közötti, tehát átlagosan nettó 62.512 Ft-os közmunkabért kapnak. Ez mindössze 49,2\%a az elsődleges munkaerőpiacon dolgozó tiszabőiek átlagos fizetésének.

A nyílt munkaerőpiacon dolgozók - iskolai végzettségük mellett - háztartásainak bevételei is magasabbak, ahol átlagosan havi nettó 211.500 Ft-os bevételhez jutnak, míg az elsődleges munkaerö-piaci szempontból inaktív tiszaböiek háztartásainak bevétele nettó $164.840 \mathrm{Ft}$. Tehát az inaktív háztartásfővel rendelkező bevétele mindössze megközelítőleg háromnegyede $(77,9 \%)$ a primer munkaerőpiacon dolgozók háztartási jövedelmének. Viszont a nyílt munkaerő-piaci állással rendelkezők háztartásainak mérete kisebb (átlagosan 4 fó), mint az aktív korú inaktív háztartásoké (átlagosan 6 fô). Ezért az egy före jutó jövedelem mértéke az első csoport esetében közel kétszeres $(52.875 \mathrm{Ft})$ az inaktív háztartások tagjaihoz $(27.473 \mathrm{Ft})$ viszonyítva. Az elsődleges munkaerőpiacon inaktív csoporton belül a közmunkaprogramban foglalkoztatott háztartások bevétele a legalacsonyabb $(159.400 \mathrm{Ft})$, ahol az átlagos háztartásméret 6 fő és az egy főre jutó jövedelem 27.109 Ft. Így miközben az elsődleges munkaerőpiacon dolgozók háztartásaiban élők ,csak” a létminimum (71.800 Ft) alatt élnek, addig a nyílt munkaerőpiacon inaktívak háztartásaiban élők egy főre jutó bevétele a szegénységi küszöbként meghatározott $28.500 \mathrm{Ft}$-ot sem éri el.

5.2. A szegénység kultúrájának hatása a tiszabői hátrányos helyzetűek hosszú távú munkahelymegtartására

A megkérdezett, munkaerő-piaci szempontból aktív korú tiszabőiek 70\%-a általában több évig dolgozik egy munkahelyen, 30\%-uk pedig csak néhány hónapot tölt el egy vállalatnál. A munkaképes korúak leghosszabb egybefüggő munkavégzése átlagosan hat évig (72 hónap) tartott, és a kutatás időpontjáig a karrierjük során többségük négy munkahelyen dolgozott. A munkahelyváltások okai között elsősorban a vállalat megszűnése játszott szerepet, de az alacsony fizetés és a távolság, valamint a nehéz bejárási körülmények is munkahelyváltást eredményeztek, míg létszámleépítés miatt a kutatási mintába került aktív korúak csak kis csoportja váltott munkát. 
10. táblázat - A megkérdezett tiszabői aktiv korúak munkahelyváltásának okai

\begin{tabular}{|l|c|}
\hline Munkahely megszünése & $30 \%$ \\
\hline Fizetéssel való elégedetlenség & $16 \%$ \\
\hline Lejáró szerződés & $12 \%$ \\
\hline Gyermekvállalás & $9 \%$ \\
\hline Létszámleépítés & $7 \%$ \\
\hline Családi okok & $5 \%$ \\
\hline Egészségügyi probléma & $5 \%$ \\
\hline Túlzottan nehéz feladatokkal járó munkakör & $2 \%$ \\
\hline \multicolumn{2}{|c|}{ Forrás: saját adatok } \\
\hline
\end{tabular}

A mintába került, elsődleges munkaerőpiacon alkalmazásban álló tiszabőiek többsége (83,3\%) több évig dolgozik egy munkahelyen és csak 16,7\%-uk jelezte, hogy csupán néhány hónapot tölt el egy vállalatnál. A nyílt munkaerőpiacon dolgozóknak a kutatás időpontjáig átlagosan négy munkahelyük volt. A váltások okai között elsősorban a munkahely megszünése, létszámcsökkentés, és a szerződés lejárta, valamint a távolság és a nehéz bejárási körülmények állnak, de jellemző volt, hogy a gyes, gyet, vagy gyed után történő visszatérésre nem adtak lehetőséget, vagyis gyermekük születése után új munkahelyet kellett keresniük. A leghosszabb egybefüggő munkaviszony átlagosan nyolc és fél év (102 hónap) volt, amit a tiszabői - jelenleg is az elsődleges munkaerőpiacon dolgozó - munkavállalók egy munkahelyen eltöltöttek. Ök jelenlegi munkahelyükön átlagosan hat éve és három hónapja dolgoznak. A megkérdezett, nyílt munkaerőpiacon elhelyezkedő falubeliek legfontosabb szempontja jelenlegi munkájuk elvállalásakor a fizetés mértéke, a munka és a bér megfelelő aránya volt (42\%), míg a munkahelyi és emberi környezetet a válaszadók egynegyede (25\%) jelezte. A többi válaszadó a munka típusát és a munkahely földrajzi elhelyezkedését említette, amely esetben fontos volt, hogy helyben legyen, vagy ne kelljen sokat utazni. Emellett jelezték a munkaszerződés időtartamát, amelynél lényeges szempontként jelent meg, hogy minél hosszabb távra szóljon. Egyes válaszadók viszont nem néztek semmilyen szempontot jelenlegi munkájuk elvállalásakor, hiszen ,,örültem, hogy van lehetőségem dolgozni” (55 éves tiszabői nő).

A kutatási mintába került aktív korú inaktív községbeli lakosok 11,3\%-ának az adatfelvétel időpontjában (2016. augusztus) semmilyen kereső tevékenységből származó bevétele nem volt. E csoport tagjai átlagosan közel három éve (35 hónapja) nem folytattak munkatevékenységet, 56,9\%-uk viszont még soha nem végzett hivatalos munkát az elsődleges munkaerőpiacon. A többi munkaképes korú inaktív $(43,1 \%)$ átlagosan nyolc éve és kilenc hónapja (105 hónapja) dolgozott utoljára hivatalosan. Az aktív korú inaktív falubeliek legutóbbi munkahelyükön átlagosan nettó 71.048 Ft-ot 
kerestek. Ha figyelembe vesszük, hogy a kutatást megelőzően átlagosan nyolc éve és kilenc hónapja végeztek utoljára hivatalos munkát a nyílt munkaerőpiacon, akkor láthatjuk, hogy 2007-es $114.100 \mathrm{Ft}$ hazai nettó átlagfizetéshez ${ }^{55}$ képest pontosan az adott év átlagkeresetének 62,5\%-át vitték haza, amely összeggel a tiszaböiek háromnegyede $(75 \%)$ elégedett volt.

A megkérdezett inaktívak legutolsó nyílt munkaerő-piaci pozíciójukhoz kapcsolódó munkakör feladatainak betanulása szinte mindegyikük számára $(96,6 \%)$ könnyen ment, és feladatok határidőre teljesítése sem okozott gondot (91,3\%). Többségük $(55,2 \%)$ optimálisnak tartotta a rábízott munka mennyiségét, tehát nem érezték magukat túlterhelve. Az elsődleges munkaerőpiacról kiszoruló falubeliek utolsó munkaviszonyának megszünése jellemzően öt okhoz kapcsolódik: (1) közös megegyezéssel felmondtak, vagy (2) létszámleépítés miatt szünt meg a munkahelye, esetleg (3) áthelyezték részmunkaidős állásba, amely miatt már ,,nem érte meg” (41 éves tiszabői nő) az elsődleges munkaerőpiacon dolgozni. Emellett (4) egészségügyi probléma is szerepet játszott az állás megszünésében, illetve (5) a közmunkaprogramhoz kapcsolódó pozíció miatt is hagyták el nyílt munkaerő-piaci állásukat.

A munkaképes korú inaktív községbeli lakosoknak átlagosan négy munkahelyük volt; a leghosszabb, egybefüggő munkaviszony átlagosan öt évig és egy hónapig tartott. A váltások oka elsősorban a munkahely megszünésére vezethető vissza (30\%), ugyanis többnyire olyan nagyobb, a szocialista gazdaságra berendezkedő foglalkoztatók szüntek meg, mint az Állami Építőipari Vállalat, a tiszabői Petőfi Termelői Szövetkezet, vagy a fegyverneki konzervgyár. A munkahelyváltások második leggyakoribb okai anyagi jellegüek voltak (22\%). Ilyen esetekben vagy a fizetés mértékével nem voltak elégedettek, amelynek köszönhetően volt, aki a közfoglalkoztatást választotta, mivel az elsődleges munkaerő-piaci állásában ugyanazt a bért kapta, ,de így legalább nem kell korán kelni” (45 éves tiszabői férfi), vagy megszünt a bejárási támogatás, amely jelentősen megnövelte az utazási költségeket és már nem érte meg ingázni. Munkahelyi problémák (11\%) okozta váltások hátterében többnyire az időszakos-, vagy részmunkaidős alkalmazásra való áttérés, esetenként az előre megbeszélt feltételek be nem tartása állt a háttérben, de a bérek ki nem fizetése is a munkahelyváltás magyarázatául szolgált. Emellett családi okok, egészségügyi probléma, és létszámleépítés következtében is munkahelyet váltottak a kutatás mintájába került inaktív falubeliek.

55 STATISZTIKAI TÜKÖR 2008 
11. táblázat - A kutatási mintába került inaktív tiszaböiek korábbi munkahelyváltásaik okai

\begin{tabular}{|l|c|}
\hline Munkahely megszünése & $30 \%$ \\
\hline Fizetéssel való elégedetlenség & $22 \%$ \\
\hline Lejáró munkaszerződés & $11 \%$ \\
\hline Munkahelyi problémák & $11 \%$ \\
\hline Bejárási nehézségek & $8 \%$ \\
\hline Gyermekvállalás & $5 \%$ \\
\hline Egyéb okok & $13 \%$ \\
\hline
\end{tabular}

A megkérdezett aktív korú inaktív tiszabőiek legfontosabb szempontja egy munka elvállalásakor a fizetés mértéke lenne (34\%), természetesen többen kiemelték, hogy a közmunka bérénél magasabb juttatást várnak el. A második legfontosabb szempontot a munkahely elhelyezkedése és a bejárási lehetőségek jelentik (28\%), itt elsősorban helyi, vagy közeli településen található munkát jeleztek elfogadhatónak. A harmadik jelentős szempont a munka típusa (15\%), amelynél a könnyen megoldható feladatokat részesítik elönyben, de a végzettségnek és életkornak megfelelő állást is kiemelték. A többi válaszadó a munkahelyi és emberi környezetet jelezte a munkahelyválasztás aspektusaként, emellett a munkarendet, időbeosztást emelték ki, hiszen sokuk számára fontos, hogy a gyerekek iskolai programjának végére - általában 16 órára - otthon tudjanak lenni. Egyes válaszadók viszont nem néznének semmilyen szempontot egy elsődleges munkaerö-piaci állás elvállalásakor.

A munkahelyi szocializáció mind az elsődleges munkaerőpiacon dolgozó válaszadók jelenlegi munkahelyein $(91,7 \%)$, mind pedig az aktív korú inaktívak legutóbbi, nyílt munkaerőpiacon található munkahelyén $(88,9 \%)$ könnyen és problémamentesen történt.

Következésképpen a mintába került megkérdezettek válaszai alapján elmondható, hogy a szegénység kultúráját elsajátított csoportokra jellemző, más környezetbe - iskola, munkahely - történő nehéz beilleszkedés nem jellemző a rurális jellegü periférián élőkre. Emellett az eredményekből kiderült, hogy mindkét aktív korú csoport többsége jellemzően több évet dolgozik egy-egy munkahelyen. Ez az arány a jelenleg is a nyílt munkaerőpiacon dolgozók esetében magasabbnak mondható és a leghosszabb, egy munkahelyen eltöltött időtartam is tovább tartott, mint az aktív korú inaktívak esetében. 
12. táblázat - A munkahelyi szocializáció és a munkahelymegtartás különbségei a nyílt munkaerö-piaci jelenlét aspektusából

\begin{tabular}{|l|c|c|}
\hline & $\begin{array}{l}\text { Nyílt munkaerőpiacon } \\
\text { dolgozók }\end{array}$ & $\begin{array}{l}\text { Elsődleges munkaerö-piaci } \\
\text { szempontból inaktívak }\end{array}$ \\
\hline $\begin{array}{l}\text { Problémamentes munkahelyi } \\
\text { szocializáció }\end{array}$ & $91,7 \%$ & $88,9 \%$ \\
\hline $\begin{array}{l}\text { Jellemzöen több évet egy } \\
\text { munkahelyen dolgozók aránya }\end{array}$ & $83,3 \%$ & $66,7 \%$ \\
\hline $\begin{array}{l}\text { Egy munkahelyen eltöltött } \\
\text { leghosszabb időtartam átlaga }\end{array}$ & 102 hónap & 61 hónap \\
\hline
\end{tabular}

Forrás: saját adatok

Az eredmények alapján elmondható, hogy mind a jelenleg a nyílt munkaerőpiacon aktív, mind az aktív korú inaktívak könnyedén, nehézségek nélkül szocializálódtak jelenlegi, illetve korábbi munkahelyükön, és több éven keresztül meg tudták tartani pozíciójukat.

A helyi lakosokkal készített félig strukturált interjúk alapján nyilvánvalóvá vált, hogy a periférikus területeken élő hátrányos helyzetüek a földrajzi elszigeteltségéből, másrészt jellemzően alacsony iskolai végzettségükből adódó jelentős információhiány és szervezőképességük alacsony szintje miatt nem, vagy csak nehezen képesek saját maguk megszervezni nyílt munkaerő-piaci elhelyezkedésüket. Emellett kiderült, hogy a községben élő emberek többsége csak annyira motivált a munkavégzésre, hogy egyik napról a másikra megéljenek, de olyan jellegű inspirációval nem rendelkeznek, amelyek előre kitüzött célok elérésére és megvalósítására irányulnának. A legfontosabb motivációt az jelenti, hogy megélhetést biztosítsanak a család számára és az alapvető szükségleteiket kielégítsék. Tehát a szegénység kultúrájának egyik fő tulajdonsága, a kizárólag rövid távra tervezés erősen jelen van a Tiszabőn élök körében. Hosszú távú tervezés még a fiatalokra sem jellemző, amelyet az a szocializációs környezet is eredményez, amelyben a célt a mindennapi élelem és a napi szükséglet beszerzése jelenti. Így a gyerekek is ezt a norma- és célrendszert sajátítják el szüleiktől. Nagyobb célok, mint például autóvásárlás, vagy házfelújítás megvalósítására nincs reális esélyük, ezért a célok és az ezek eléréséhez szükséges motiváció az élelmiszer, a téli tüzelő beszerzésére, a számlák kifizetésére és tartozások rendezésére korlátozódik. 
5.3. A rurális jellegü periférikus területek földrajzi és infrastrukturális jellemvonásainak munkaerő-piaci hatásai

Az elsődleges munkaerőpiacról kiszoruló aktív korú válaszadók 38\%-uk érzi, hogy nincs lehetőségük munkát vállalni a nyílt munkaerőpiacon, amelynek okait a helyben elérhető munkahelyek alacsony száma, a szakmai képzettségük és az utazási hajlandóság hiányára vezetik vissza. A nyílt munkaerő-piacon dolgozó tiszabőiek megközelítőleg fele (46,2\%) tudott helyben elhelyezkedni, a munkahelyükre ingázók (53,8\%) pedig elsősorban autóbusszal (85,9\%) járnak dolgozni, akiknek viszont csak közel fele (42,9\%) használ közösségi közlekedést, a többiek céges buszjárattal érik el munkahelyüket. Többségüknek (71,4\%) támogatják - bérlethozzájárulás, céges buszjárat, vagy üzemanyag térítés - a munkába járását, utazási költségeit. A munkahelyükre ingázó megkérdezettek 28,6\%-a viszont nem kap semmilyen finanszírozást a törvényileg szabályozott 86\%-os az utazási támogatásból. Ez azért is jelent komolyabb nehézséget a tiszabőiek számára, mert a megye székhelyének elérése 990 Ft-ba ${ }^{56}(840 \mathrm{Ft}+150 \mathrm{Ft}$ kiegészítő díj) kerül egy felnőtt munkavállaló számára, ami a hazaúttal együtt már napi $1980 \mathrm{Ft}$ megterhelést jelent a háztartási költségvetésben. Így havi 20 munkanappal számolva már 39.600 Ft kiadással kell számolni egy szolnoki munkahely esetén, bár ez esetben kedvezőbb a 32.200 Ft értékủ havi bérlet.

„Mert itt nincs a közelben semmi (munka). Szolnokon van legközelebb, de a bejárást nem fizetik, az saját költség. ” (23 éves tiszabői nö)

Azon aktív korú inaktív válaszadók, akik szerint nehezebb tiszabőiként elhelyezkedni, 13\%-uk a térség munkahely-hiányát emelték ki, míg szintén 13\%-uk a falu földrajzi elhelyezkedését, elzártságát és az ebböl adódó tömegközlekedési nehézségeket jelezte korlátozó körülményként. A munkaképes korú inaktívak legutóbbi nyílt munkaerö-piaci állását figyelembe véve mindössze 44,8\%-uk munkahelye volt Tiszabőn. Azok, akik korábbi munkahelyük elhelyezkedése ${ }^{57}$ miatt ingázásra kényszerültek (55,2\%), átlagosan $54,2 \mathrm{~km}-\mathrm{t}^{58}$ és 57 percet utaztak munkahelyükre és ugyanennyit vissza. A korábban ingázó inaktív megkérdezettek többsége $(71,4 \%)$ céges

\footnotetext{
56 VOLANBUSZ.HU

57 Dunaharaszti, Fegyvernek, Jászberény, Kunhegyes, Mátészalka, Rákóczifalva, Szolnok, Törökszentmiklós

${ }^{58}$ A távolság és idő számítását a maps.google.hu oldal segítségével mértem, amely a legrövidebb közúti, személyautóval történő közlekedést számítja, forgalom nélkül mérve.
} 
buszjárattal közlekedett legutóbbi munkahelyére, 21,4\%-uk pedig ismerőssel és annak jármüével járt dolgozni. Ezen válaszadók 7,1\%-a a közösségi közlekedést választotta és helyközi, vagy távolsági autóbusszal utazott a munkájába. A korábbi munkahelyükre ingázók többségének $(86,7 \%)$ legutolsó munkahelyén támogatták a bejárást, amely elsősorban (73\%) a céges buszjárat lehetőségét jelentette, a többiek számára pedig részben, vagy egészében megtérítették az utazási költségeket.

A munkavállalás és a közlekedés kapcsolatában mindenképpen figyelembe kell venni a Tiszabőtől 22 kilométerre található járási központ, Kunhegyes elérhetőségét, hiszen mind a közfoglalkoztatottak, mind pedig a munkanélküliek számára elengedhetetlen a városban található munkaügyi kirendeltség, vagyis a kormányhivatal foglalkoztatási osztályának időszakos felkeresése. Annak ellenére, hogy az elsődleges munkaerőpiacról kiszorult, vagy be nem lépett tiszabőiek 79\%-ának nem jelent problémát a kormányhivatal személyes elérése, az inaktívak kapcsolata a munkaügyi kirendeltséggel gyengének tekinthető, hiszen a nyílt munkaerő-piaci pozícióval nem rendelkezők több, mint egyötödének (21\%) nehézséget okoz a hivatal felkeresése. A megkérdezett inaktívak többsége (88,9\%) csak a közfoglalkoztatási szerződés lejártakor, illetve munkanélküliként az együttmüködési kötelezettség keretében háromhavonta sorra kerülő jelentkezések alkalmával keresi fel a kormányhivatalt. A vidéki periférikus területekre jellemző közösségi közlekedés infrastrukturális hátrányai tehát elsősorban a munkanélkülieknek jelentenek problémát, hiszen a Kunhegyesen található munkaügyi kirendeltség/kormányhivatal foglalkoztatási osztályának megközelíthetősége tömegközlekedéssel igen komplikált és esetenként a költségeit sem tudják megfizetni. Azon válaszadók, akiknek akadályokba ütközik a kormányhivatal felkeresése, elsősorban a közösségi közlekedés nehézségeit (73\%) és a magas utazási költségeket ${ }^{59}$ (20\%) emelték ki ennek okaként, ezen belül is a csatlakozások hiánya okoz problémát a kunhegyesi munkaügyi kirendeltségre való eljutás során. A harmadik akadály, amely nehezíti a személyes kapcsolattartást, a gyermekfelügyelet megoldásának nehézsége $(7 \%)$.

A vidéki periférián élők közlekedési problémái megalapozottak: a Tiszabő és Kunhegyes közötti 22 km-es távolságon közvetlenül naponta egy buszjárattal, hozzávetőlegesen egy óra (57 perc) utazással (8:13-kor indul és 9:10-kor érkezik) érhető el a kormányhivatal, de a visszaútig fennmaradó 3 óra 30 perces periódus (12:26-kor

\footnotetext{
${ }^{59}$ A Tiszabő és Kunhegyes közötti közlekedés - buszjárattól, tehát az átszállások számától függően - 465 Ft és 745 Ft-ba, átlagosan 605 Ft kerül egy útra, ami a visszaúttal együtt 1210 Ft-ot költséget jelent, amelyet a munkaügyi kirendeltség utólagosan megtérít.
} 
indul és 13:01-kor érkezik) általában kevésnek bizonyul az ügyintézés befejezéséhez, nem beszélve arról az esetről, ha a tiszaböi ügyfél ezen intervallumon kívül kap időpontot. Átszállással már jóval szélesebb a járás központjába történő utazás lehetősége: Tiszabőről reggel 5 óra 23 perckor induló első és a 16 óra 17 perckor induló utolsó járattal együtt nyolc alkalommal közlekedik autóbusz a távolságon, de Kunhegyesről legkésőbb a 16:30-as járatot el kell érni, hiszen ez utolsó visszafelé induló lehetőség. Átszállással átlagosan másfél órát (79 percet) vesz igénybe a közösségi közlekedés, amely a 46 perces legrövidebb utazási időtől a 110 percet is elérheti ${ }^{60}$. A hiányos tömegközlekedési lehetőségek miatt a kunhegyesi kormányhivatal eléréséhez egyesek sofőrszolgáltatást, „, fuvart "61 vesznek igénybe valamely autóval rendelkező falubelitől.

Ugyanakkor a tiszabőiek elsősorban a munkaügyi kirendeltségtől várnak a megoldást munkaerő-piaci helyzetükre, hiszen a megkérdezett aktív korú inaktívak $52,9 \%$-a ezen intézmény segítségével próbál munkához jutni ${ }^{62}$. Viszont az elmondások alapján egyértelművé vált, hogy a kunhegyesi kormányhivatal foglalkoztatási osztálya többnyire csak megújítja a közmunkára való alkalmasságot és nem közvetítik ki a munkanélkülieket elsődleges munkaerő-piaci lehetőségek felé6 ${ }^{63}$. Ez azért is különös, mert munkaerő-kölcsönzéssel foglalkozó vállalkozók a tiszabőiek számára a környék gyáraiban kínálnak szakképzést nem igénylő pozíciókat. A kormányhivatal viszont jelenlegi gyakorlatával konzerválja a tiszabőiek munkaerő-piaci helyzetét és a falu munkanélküliségi rátáját is. A településen nyilvántartott álláskeresők aránya a munkaképes népesség arányában az adatfelvétel idején $9,1 \%{ }^{64}$ volt, vagyis a tiszabői

\footnotetext{
${ }^{60}$ MENETRENDEK.HU alapján, munkanapon mérve.

Érdekes, hogy mind a Jász-Nagykun-Szolnok megye központjába, mind pedig a korábbi kistérségi központba, vagyis Törökszentmiklósra jelentősebb könnyebb és gyorsabb eljutni, mint Kunhegyesre. A Tiszabö és Szolnok közötti 40 km-es távolságon napi hat közvetlen buszjárat is közlekedik, amelyek átlagosan 73 perc utazást vesz igénybe. Átszállással azonban tovább hét buszjárat nyújt lehetőséget a megyeközpont elérésére, amelyekkel 65 perc alatt, tehát a közvetlen járatoknál gyorsabban közelíthető meg Szolnok. A Tiszabőtől 21 km-re található Törökszentmiklós naponta hét közvetlen járattal érhető el, átlagosan 36 perc alatt, de átszállással további hat buszjárat indul a faluból, amelyek átlagosan 31 perc alatt érnek a korábbi kistérségi központba. Tehát látható, hogy a közigazgatási változásokhoz nem igazodtak a közlekedési lehetőségek, amely a tiszabőieket hátrányosan érinti a munkaügyi kirendeltség elérése során. 61 A hiányos közösségi közlekedési szolgáltatások hatására kialakult „,piaci rést” egyes, gépjármüvel rendelkező tiszaböiek sofőrszolgáltatással igyekeznek pótolni, amely - a tömegközlekedési jegy árának többszöröséért: átlagosan $4000 \mathrm{Ft}$ - a járási központba is elfuvarozza az faluban élö inaktívakat.

62 Internetes csatornán keresztül 41,2\%-uk, személyes, vagy telefonos megkeresés által 35,3\%-uk keres munkát, míg a kapcsolati tőkéjükre alapozva családtagok, rokonok, vagy ismerősök segítségével 23,5\%uk igyekszik elhelyezkedni. A legkevésbé népszerü munkakeresési módszer az újsághirdetések szemléje, amelynek segítségével az aktív korú inaktív tiszabőiek 11,8\%-a próbál munkát találni.

${ }^{63}$ Ezt a kunhegyesi kormányhivatal foglalkoztatási osztályán meg is érősítették, amelynek oka elsősorban a munkáltatók diszkriminatív jellegü humánerőforrás-igénye. Mivel a járás nagyobb foglalkoztatói nem szeretnének roma munkaerőt alkalmazni, ezt jelezik is a munkaügyi kirendeltség felé.

${ }^{64}$ NFSZ 2016
} 
munkanélküliség a kutatás időpontjában mért országos ráta $\left(4,9 \%{ }^{65}\right)$ közel kétszeresét mutatta. Munkakeresésre viszont csak a munkaképes korú inaktívak 27\%-a fordít időt: 7,9\%-uk minden nap, 3,2\%-uk hetente, 6,4\%-a legalább havonta keres munkát, 9,5\%-uk viszont ennél ritkábban keres alkalmat az elhelyezkedésre. Az aktív korú, de az elsődleges munkaerőpiacon inaktívak - közfoglalkoztatottak és egyéb inaktív személyek - csoportjai átlagosan nettó 110.600 Ft-ért vállalnának állást a nyílt munkaerőpiacon. 74,6\%-uk ingázást is vállalná egy munkahelyre, átlagosan 59,5 km távolságra ${ }^{66}$, sőt több, mint negyedük $(26,7 \%)$ elvállalna olyan munkát is, amely miatt csak hetente tudna hazajárni.

5.4. Területi stigma és a kapcsolati tőke szerepe a rurális jellegü periférikus területeken élök munkaerö-piaci szerepvállalásban

A nyílt munkaerőpiacon dolgozó válaszadók 82\%-a és az aktív korú, de az elsődleges munkaerőpiacon inaktív válaszadók 84\%-a szerint tiszabői lakosként nehezebb munkát találni, mint a környékbeli településeken élőknek, amelyet a megkérdezettek elsősorban a faluval kapcsolatos sztereotípiák, elöítéletes gondolkodás Jász-Nagykun-Szolnok megyében való erős jelenlétével magyaráznak.

A rurális jellegü periférikus területeken kialakult területi stigma lényegesen megnehezíti az ott élők elsődleges munkaerőpiacon történő elhelyezkedését, amely a Tiszabőt övező térségben élők sztereotip, megbélyegző mentalitását jellemzi és legfeljebb a megye területére terjed ki. Az elsődleges munkaerőpiacon dolgozó mintába került falubeliek 30,8\%-nak, az aktív korú inaktívak pedig 33,3\%-ának elmondása szerint utasították már el egy munkahelyre történő jelentkezés során a Tiszabőt érintő területi diszkrimináció miatt.

„,Tiszaböiként nagyon nehéz munkát találni, hiszen a falu hírneve miatt az ott élöket a munkaadók sztereotipizálják.” (37 éves tiszabői férfi) „Mert ismerik mi van Tiszabőn, leirják az idevalósiakat.” (52 éves tiszaböi férfi) ,,Sokkal nehezebb (elhelyezkedni), mert rossz vélemény alakult ki a faluról. A médiában is sokszor szerepel." (45 éves tiszabői nö)

${ }^{65}$ KSH 2016A, STATISZTIKAI TÜKÖR 2017

${ }^{66}$ Akik jelenleg a közmunkaprogramban részt vesznek, ők átlagosan nettó 111.700 Ft-ért állnának munkába a nyílt munkaerőpiacon, 76,7\%-uk vállana ingázást és átlagosan 60,3 km-t lennének hajlandóak utazni munkahelyükre. 
Az elsődleges munkaerőpiacon található vállalatoknál végzett munkavégzés során már nem tapasztalható diszkriminatív különbségtétel a munkavállalók között: a nyílt munkaerő-piaci állással rendelkező válaszadók 92,3\%-a nem érzett hátrányos megkülönböztetést a munkahelyén, és a jelenleg az elsődleges munkaerőpiacon inaktív munkaképes korúak 75\%-a sem tapasztalt diszkriminációt korábbi, nyílt munkaerőpiacon található pozíciójában. A területi diszkriminációt jelző munkaerő-piaci hátrány ellensúlyozása érdekében a helyiek sokszor nem a bejelentett lakcímüket adják meg egy munkára történő jelentkezéskor, többen pedig lakcímet váltottak és átjelentkeztek a megye más településén élö rokonaikhoz.

„,Tiszabö hírneve miatt más települést kell megadni a Szolnok környéki munkákhoz.” (46 éves tiszabői nő)

A területi stigma, a Tiszabőről kialakult általános kép és a faluval kapcsolatos elöítéletes gondolkodás nemcsak a munkaerőpiacon érezteti hatását, hanem megjelenik a hivatali ügyintézésben, a közszolgáltatások területén és a piaci szektorban is. A helyiekkel készített interjúk alapján a korábbi, Tiszabőhöz tartozó törökszentmiklósi munkaügyi kirendeltségen ${ }^{67}$ lekezelően foglalkoztak a tiszabőiekkel. A helyiek elmondása szerint a Tiszabőn élő munkanélküliek körében gyakran előfordul, hogy nincs pénzük kifizetni a kormányhivatalba történő utazáshoz szükséges buszjegy árát, emiatt csak később, más alkalommal tudnak menni a kötelező személyes megjelenésre. A községben élő megkérdezettek szerint a törökszentmiklósi kirendeltség munkatársai emiatt - a körülményeket figyelmen kívül hagyva - egy évre megvonták a támogatást. Az elmondások alapján a tiszabőieket jelenleg is kiszolgáló kunhegyesi kormányhivatal foglalkoztatási osztályának munkatársai viszont jóval segítőkészebbek és megértőbbek. $\mathrm{Az}$ interjúk eredményei szerint a területi stigma a piaci (banki kölcsön) és a közszolgáltatások (egészségügy) során is negatívan befolyásolja a tiszabőiek életét.

„Ha valahol meghallják, hogy Tiszabö, akkor legyintenek és csodálkoznak. Boltban, orvosnál van fóként ilyen jellegü megjegyzés. ” (60 éves tiszabői nő)

\footnotetext{
${ }^{67}$ Korábban Törökszentmiklós volt a kistérség központja, ezért a tiszabőiek az itt található munkaügyi kirendeltséghez tartoztak. A járási rendszer közigazgatási bevezetésével Tiszabő a Kunhegyesi járáshoz került, ezért a faluban élő munkanélküliek jelenleg a járási központban található, tehát a kunhegyesi kormányhivatal foglalkoztatási osztályához tartoznak.
} 
Egyes interjúalanyok megjegyezték, hogy a banki kölcsön telefonos igénylésekor már a jelentkező nevéből következtetnek, és - ha például a faluban igen gyakori „Mága” vezetéknévvel jelentkezik kölcsönért - nem biztosítanak számára hitelt. A faluról alkotott negatív imázs miatt hasonló a helyzet az orvosi szolgáltatások területén is. Több válaszadó jelezte, hogy - a községben tapasztalható folyamatos orvosi jelenlét és a sürgősségi ellátás hiánya ellenére - a tiszabőiek nem tudják igénybe venni a legközelebbi, fegyverneki egészségügyi ellátást, mert a település rendelőjében dolgozó orvosok nem hajlandók megvizsgálni a tiszabőieket.

Az elsődleges munkaerő-piaci pozíciók megszerzésében a periférikus területeken fontos szerepe van a kapcsolati tőkének. Az állással rendelkező válaszadók 53,8\%-a helyezkedett el családtagok, rokonok, ismerősök, vagy az ismerősi körükbe tartozó munkaerő-kölcsönzéssel foglalkozó vállalkozók segítségével. Emellett a korábban a nyílt munkaerőpiacon dolgozó, jelenleg inaktívak 64,3\%-a is kapcsolati tőkéjének segítségével szerezte legutóbbi állását. A tiszabőiek számára munkalehetőséget kínálnak az évente több alkalommal tartott toborzások, amely során munkaerö-kölcsönzéssel foglalkozó vállalkozók érkeznek a faluba, akik bizonyos - általában gyári szalagmunkákon végezhető - munkakörökre dolgozókat keresnek. Ilyenkor a kapcsolati tőke segítségével gyorsan terjed az információ a faluban, és aki szeretne elhelyezkedni, ekkor tud jelentkezni. Ezek az események alkalmi és folyamatos munkalehetőségeket is kínálnak a helyiek számára, de az interjúk során kiderült, hogy a faluval kapcsolatos sztereotípiák miatt Tiszabőre már csak akkor jönnek a munkaerő-közvetítők, ha máshol nem találnak munkavállalókat.

„A település negativ megitélése; sokan félnek ide bejönni.” (39 éves tiszabői nő)

Elsősorban az őszi időszakban van jelentősebb munkakínálat, mivel a környező gyárak a közelgő karácsony miatt növelik a termelést, amely a munkaerő-felvételre is pozitívan hat. Ezek hosszú távú, stabil munkahelyet jelenthetnek a tiszabőiek számára, amellyel körülbelül 120.000 forintos nettó jövedelemhez juthatnak. A három müszakos munkarendben végzett munka során három munkanapot egy szabadnap követ. Ilyen lehetőséget biztosít a tószegi Accel Hunland kerékpárgyár, a jászapáti és a jászberényi Jász-Plasztik műanyaggyár, de a törökszentmiklósi hűtőházak és a szolnoki Eagle Ottawa bőrgyártó vállalat, valamint a jászfényszarui Samsung gyár is elhelyezkedési lehetőséget jelent a tiszabőieknek. Tehát a kapcsolati tőke segítségével a környező gyárakban el lehet helyezkedni, de a helyiek elmondása alapján, ha a vezetők valamelyik 
tiszabői dolgozóban csalódnak, ez az általánosítás miatt tovább nehezíti a falubeliek munkavállalási lehetőségeit.

A nyílt munkaerő-piaci lehetőségekhez hasonlóan a másodlagos munkaerőpiacon is fontos a kapcsolati tőke, viszont itt a polgármesterrel és az önkormányzati képviselőkkel való viszony minősége határozza meg a közmunkaprogramba való bekerülés lehetőségét, amelynek alapját elsősorban egy látszólagos politikai preferencia, az önkormányzati választásokon leadott szavazat határozza meg.

5.5. A közmunkaprogram hatása a szegénység kultúrájára és a hátrányos helyzetüek elsődleges munkaerő-piaci integrációjára

Az aktív korú inaktív tiszabői válaszadók számára - saját megítélésük alapján - az elsőszámú lehetőséget a közmunkaprogram jelenti az elhelyezkedésre (47\%). Bár elmondásuk szerint a környéken található gyárak betanított - általában szalag melletti, összeszerelő, operátori - munkalehetőségei (29\%) és a meglévő képesítéshez kapcsolódó munkakörök is lehetőséget nyújtanak (12\%) a nyílt munkaeröpiacon való elhelyezkedésre, egyes helyiek szerint ezek a lehetőségek nem hivatalosak, vagyis feketemunkákat jelentenek, ezért ,jobb a közmunka” (36 éves tiszabői férfi). Emellett az építőipari segédmunkák, illetve napszámban végezhető szezonális, mezőgazdasági munkák (6-6\%) jelentenek esélyt a pénzkeresetre. Azonban a munkaképes korban lévő inaktív válaszadók 90,9\%-a (a faluban élő összes aktív korú 43,2\%-a) jelenleg is a falu közfoglalkoztatási programjában dolgozik.

A kutatás idején a közfoglalkoztatottak átlagéletkora 36,2 év volt, közülük a legfiatalabb 17 éves, a legidősebb személy pedig 62 éves volt. Érdekesség, hogy a közmunkaprogramban dolgozók 15,2\%-a volt 25 évnél fiatalabb, amely korosztály csak indokolt esetben - családi-, szociális helyzet, vagy a térségbeli munkaerőhiány esetén -, külön engedéllyel ${ }^{68}$ vonható be a közmunkaprogramba.

\footnotetext{
${ }^{68}$ A 1139/2017. (III.20.) számú rendelet szerint a 25 év alatti fiatalokat csak abban az esetben lehet bevonni a közfoglalkoztatásba, ha az Ifjúsági Garancia Program nem kínál számukra más reális munkaerő-piaci lehetőséget (MAGYAR KÖZLÖNY 2017, HAJDU et al 2016). Az intézkedés kormányzati célja a fiatalok Ifjúsági Garancia Programba történő bevonása, amellyel a kormány szeretné elérni, hogy - a fiatalok alkalmazásáért járó kedvezmények segítségével - e korosztályhoz tartozók az elsődleges munkaerőpiacon helyezkedjenek el. A program garantálja, hogy a fiatalok a programban kerülés után négy hónapon belül állásajánlatot, vállalkozóvá válási támogatást, munkatapasztalat szerzést, vagy képzési lehetőséget kap, amellyel javul munkaerö-piaci helyzetük (IFJÚSÁGI GARANCIA AKCIÓTERV 2014). Viszont a 15 és 25 és közötti - tanulmányaikat befejezett - tiszabői fiatalok mindössze 15,3\%-a talált munkát az elsődleges munkaerö-piacon, 41,7\%-uk a közmunkaprogramban dolgozik, 6,9\%-uk kizárólag alkalmi munkavégzésből (eseti megbízással, vagy napszámos tevékenységből) tartja fenn magát. Emellett 1,4\%uk szociális támogatásra jogosult, 34,7\%-uk pedig sem az elsődleges, sem a másodlagos munkaerőpiacon nem helyezkedett el. Tehát a kormány célja - a nyílt munkaerőpiacon való alacsony szerepvállalás miatt -
} 
A tiszabői közmunkaprogramba történő bekerülési folyamat egészét tekintve természetesen nincs és nem is lehet különbség a program meghatározott felvételi eljárásához képest. Minden közfoglalkoztatott a Jász-Nagykun-Megyei Kormányhivatal Kunhegyesi Járási Hivatalának Foglalkoztatási Osztályán, vagyis a munkaügyi kirendeltségen keresztül került a közmunkaprogramba, de a bekerülés gyakoriságában és hosszában mégis jelentős eltéréseken lehet tapasztalni. A programban dolgozók átlagosan négyszer kerültek be újra a közfoglalkoztatásba, de az emberek jellemzően különböző időtartamot tudnak egyszerre dolgozni. A legtöbben a 2014-es önkormányzati választások óta dolgoznak közmunkásként, viszont egyeseknek a folyamatos foglalkoztatás és szerződésmegújítás helyett több hónapot is várniuk kell a munkahelyre. A kapcsolati tőke megléte a közfoglalkoztatásánál is lényeges elem, hiszen általános vélekedés szerint a polgármesterrel való jó ismeretségi viszony szükséges, hogy valaki részt tudjon venni és tartósan bent is tudjon maradni a közmunkaprogramban.

„Amióta ez a polgármester van, egyhuzamban dolgozok. Jelentkeztem, kiválasztottak.” (28 éves tiszabői nő)

Több válaszadó is említette, hogy a család mérete is fontos kiválasztási szempont, tehát szociális kritériumok is érvényesülnek a helyi feltételek között.

„A polgármester nézi, ki a szegény, föleg ha látja, hogy sok a gyerek.” (35 éves tiszaböi nő) „Ha felvételek vannak, a polgármester lássa, és segít, föleg ahol sok a gyerek.” (41 éves tiszabői nő)

Akiknek nincs lehetőségük folyamatosan dolgozni, általában 1-3 hónap kihagyás után kerülnek vissza közfoglalkoztatásba, de elöfordult, hogy 6-7 hónapot is kellett várni a bekerüléshez. A strukturálatlan interjúk és a nyitott kérdésekre való válaszok során egyértelmüen kiderült, a helyiek úgy gondolják, hogy a programba való kiválasztás folyamatában a polgármester előnyben részesíti a választásokon rászavazó lakosokat. Az „ellenszavazás” áthidalásának a lehetőségét éppen a polgármester, vagy egy képviselőtestületi tag vállalkozásából való, helyi szinten jelentősebb - hitelre történő vásárlás biztosítja, amely lehetővé teszi a közmunkaprogramban való

a rurális jellegű periférikus területeken élö 15 és 25 év közötti hátrányos helyzetü fiatalok körében nem valósult meg. 
munkalehetőséget ${ }^{69}$. A hitel visszafizetése a közmunkabérből történő havi levonások által az „eladó” számára garantált.

Természetesen a munkaügyi kirendeltség - kormányhivatal - által kiközvetített munkavállalók a közmunkaprogramba való jelentkezését az önkormányzat részéről nem lehetne elutasítani, és ezt hivatalosan nem is teszik. Ezért amikor egy „nem a polgármesterre szavazó" jelentkezik munkára, akkor papíron felveszik, de a jelentkezőnek jelzik, hogy „betelt a helyek száma”, majd öt napon keresztül „H” betüt, vagyis hiányzást írnak be hozzá, amely miatt megszüntethetik a közmunkaprogramban való munkaviszonyát. Emiatt a jelentkező a későbbi szociális támogatásoktól is elesik, úgy hogy közben maga sem tudja, hogy bekerült a közmunkaprogramba ${ }^{70}$.

„A polgármestertöl függ, hogy ki kap munkát. Ha valakire haragszik, kihúzza a listáról.” (42 éves tiszabői férfi)

A nem a polgármesterre szavazó, programban lévő azon dolgozók esetében, akik nem vásároltak a vállalkozásban, alkalomszerüen a szabadságra kivett napok helyett hiányzást jegyeznek be, amely a limit elérése után a közmunkaprogramból való kizárást vonja magával. A visszaéléseket a közmunkások nem jelzik; egyrészt nem ismerik a lehetőségeiket, amelyek ilyen esetekben a munkaügyi felügyelethez irányítanák őket, másrészt a helyiekkel készített interjúk információi alapján, bármilyen panasz esetén nem csak az adott dolgozót, hanem az egész rokonságát menesztik a közmunkaprogramból. Más munkalehetőség hiányában pedig munka és - a szabályok értelmében - szociális támogatás nélkül maradnak.

A közmunkára való jelentkezés elutasítását azonban nem mindenki érzékeli diszkriminatív intézkedésnek, hiszen jelentkezés és felvétel során csak a dolgozók $17,7 \%$-a érzékelt hátrányos megkülönböztetést ${ }^{71}$. Viszont a felvétel során több, mint minden negyedik jelentkező $(26,6 \%)$ tapasztalt már elutasítást, amelyet az önkormányzat

\footnotetext{
69 Több válaszadó is megerősítette, hogy a közmunkaprogramba való bekerüléshez legalább 20 tyúkot, vagy 20 kilogramm nyers sertéshúst kell a polgármestertől vásárolni (átlagosan $1000 \mathrm{Ft} / \mathrm{kg}$ áron, amely a vásárolt mennyiségtől is függ) hitelre, amit a közmunkabérből folyamatosan levonnak.

${ }^{70}$ A közmunkaprogramba való bekerülés után azonnali hatályú felmondással az önkormányzat akkor élhet, ha a dolgozó rendszeresen ittas, ha hanyagul bánik a rábízott eszközökkel, ha rendszeresen nem végzi el napi munkáját, ha veszélyezteti munkatársai biztonságát, vagy ha többször igazolatlanul hiányzik. A dolgozó pedig akkor léphet ki, ha a munkáltató méltatlan körülményeket teremt, nem megfelelö eszközöket nyújt, hiányos a munkabiztonság, kevés a pihenőidő, vagyis megalázzák, zaklatják, vagy hátrányosan megkülönböztetik (VARGA et al. 2013).

${ }^{71}$ E csoportba tartozók elsősorban úgy érzik, hogy azért nem kaptak lehetőséget a közmunkaprogramban, mert nem a jelenlegi polgármesterre szavaztak, kisebb arányban pedig a sertéstelepröl való vásárlás hiányának tulajdonítják hátrányos megkülönböztetésüket.
} 
oldaláról elsősorban a teljes keret foglalkoztatásával (53\%) indokoltak. Bár többek szerint az elutasítás első számú okát a választásokon másik polgármesterjelöltre való szavazat jelentette (23\%), míg 12\%-uk olyan egyéb okoknak tulajdonítja, amely szerint nem szimpatikusak a polgármesternek, vagy nem vásárolt a képviselő-, vagy a polgármester vállalkozásából. Egyes tiszabőieknek pedig nem magyarázták meg a döntést (12\%), amely később a szociális támogatások megvonásával jár együtt.

„Nem indokolták meg, de utána még a segélyt is elvették.” (44 éves tiszabői nő)

A közmunkaprogramban részt vevők átlagosan nyolc és fél hónapot dolgoznak egy évben, napi nyolc órás munkavégzésben. A közfoglalkoztatás során végzett feladatok esetében hat típust - adminisztratív tevékenység, értékteremtő munka, betanított munka, segédmunka, képzésen való részvétel, brigádvezetői feladatok - lehet megkülönböztetni, amelyekbe általában a polgármesterrel kialakított személyes kapcsolat minősége alapján kerülnek a dolgozók. Adminisztratív tevékenységet a közmunkások mindössze 7\%-a végez, amely munkakörben dolgozók a programban résztvevők dokumentációjának kezelésével foglalkoznak, könyvelik a hiányzásokat, szabadságokat, illetve elkészítik a munkabeosztást. Az önkormányzat hivatali dolgozóinak egy része - például adminisztrátor, munkaerő-piaci menedzser - is a közmunkaprogram keretében van foglalkoztatva. Nem meglepö és nem is egyedi eset, hogy az önkormányzat a dolgozók munkaerő-piaci lehetőségének alacsony szintjét kihasználva bocsát el alkalmazottakat és veszi vissza őket a közmunkaprogram keretében. Így a hivatal - költségeik csökkentése érdekében - a közmunkaprogram keretében visszafoglalkoztatja korábbi közalkalmazottait, tehát a dolgozók ugyanazt a munkát végzik, mint a közmunkaprogram előtt, de kevesebb pénzért és kiszámíthatatlan munkaszerződéssel. A jelenlegi rendszer az önkormányzatot is arra ösztönzi, hogy a $\mathrm{FHT}^{72}$-seknek adjon közmunkát, hiszen a közfoglalkoztatási munkabér esetében a fizetést az állam folyósítja. Emellett az önkormányzat számára további előnyt jelent, hogy a közmunkaprogram jogi szabályozása szerint a dolgozóknak évente 20 nap szabadság jár, amely nem veszi figyelembe a többi, foglalkoztatásra irányuló jogviszonyban leírt pótszabadságok szabályozását, vagyis nem függ a dolgozók életkorától és esetleges gyermekek számától.

${ }^{72}$ Foglalkoztatást helyettesítő támogatás, amelynek összege az öregségi nyugdíjminimum $80 \%$, vagyis nettó 22.800 Ft (EMMI 2017). 
Ennek eredménye, hogy a közmunkaprogram kiszorítja az alacsonyan képzett munkaeröt az elsődleges munkaerőpiacról ${ }^{73}$.

A faluban jelentős az értékteremtő közfoglalkoztatás (28\%) szerepe, ennek keretében fóliaházi növénytermesztéssel, drótfonással, illetve vályogtégla készítéssel foglalkoznak. A közmunkások egy része az önkormányzat tulajdonában lévő fóliaházakban mezőgazdasági tevékenységgel paradicsomot és paprikát termeszt (Melléklet 4., 10. és 11. kép), - egyes falubeliek szerint - a megtermelt zöldségek egy részét pedig az iskola konyhájának adják, másik felét pedig szétosztják a dolgozók között ${ }^{74}$. A kutatás időpontjában a drótfonók és a vályogtégla készítők munkáinak produktumai az önkormányzat által építtetett irattárnál kerültek felhasználásra. A betanított munkások (8\%) által végzett munka sokrétü lehet: egy részük a falu határában földmunkát végez, mások füvet nyírnak, míg egyesek karbantartó feladatokat látnak el, de az említett irattár is a közmunkaprogramban dolgozó kőmüvesek által épült, sőt a járdalapokat is ök újították fel. A közmunkások negyedik csoportját a segédmunkások (39\%) alkotják, akik a faültetéshez szükséges kapálás, kaszálás, gereblyézés mellett szemétszedéssel és az utcák tisztántartásával foglalkoznak. A közmunkaprogram keretében lehetőség van képzettség megszerzésére is, amelyre a tiszabői közmunkások 15\%-ának van lehetősége. A kutatás időpontjában postai kézbesítő, kosárfonó és növénytermesztő tanfolyamokon tudtak részt venni a jelentkezők. A közfoglalkoztatottak mindössze 3\%-át alkotják a brigádvezetők, akik a többi szakképzettséget nem igénylő munkakörben - dolgozónál magasabb bérért végzik vezetői feladataikat. E munkakör megítélése a dolgozók körében többrétü; a brigádvezetők a polgármester közeli ismerősei közül kerülnek ki, ezért diszkriminatív jelleggel, másként kezelik azokat a dolgozókat, akik a falu jelenlegi vezetőjére szavaztak, mint akik a másik jelöltre adták voksukat. Bár a falu vezetőjére adott szavazat nem jelent biztos közmunkapozíciót, általában a ,jó helyre szavazók” a falu területén belül, vagy vezetői feladatokat ellátva, esetleg a hivatalban adminisztratív munkakörben vannak alkalmazva. A „nem megfelelően szavazók” által alkotott csoportot a közbeszéd szerint - a kurrens menekültügyi problémára utalva - a „migránsok” alkotják, akik a falu szélén,

\footnotetext{
${ }^{73}$ KÁlmÁN 2015, HoRVÁTH 2017

${ }^{74}$ Mások szerint azonban a megtermelt zöldségek a polgármester sertéstelepén kerülnek felhasználásra a malacok élelmezése során.

Tiszabőn nem jellemző kiskertek megmüvelése, vagyis az önellátás céljára irányuló növénytermesztés. Ennek egyik oka, hogy a közfoglalkoztatás során a fóliaházakban megtermelt növények egy részét feltehetően - elosztják a dolgozók között. Emellett az önellátásra termelés elterjedésének hiányára a szegénység kultúrájára jellemző rövid távra tervezés is hatással van, hiszen a kertek megmüvelésének leghamarabb 4-5 hónap múlva lesz eredménye, amely meghaladja a mélyszegénységben élő emberek tervezési időszakát.
} 
az első csoportnál nehezebb munkákat végzik, vagy a polgármester telepén kapnak feladatokat.

Mindezek ellenére a periférikus területeken helyben elérhető munkahelyek hiánya miatt folyamatos igény van a közmunkaprogramban való részvételre. Sőt, a közmunkások szerint egyre nehezebb bekerülni. Emiatt az önkormányzatok részéröl olyan visszásságok is tapasztalhatóak, amelyek az erős függőségi viszonyok miatt alakulhattak ki. A hátrányos helyzetü rétegek tájékozatlanságát és munkaerő-piaci kiszolgáltatottságát kihasználva egyes településvezetők egyfajta kiváltságként osztják a közmunkát, vagy magasabb fizetési kategóriában alkalmazzák rokonaikat, mint azt a szabályok engedik. Gyakran előnyben részesítik a választásokon rászavazó lakosokat vagy éppen annak adnak közmunkát, aki a béréből valamilyen úton visszafizet a képviselöknek. Esetenként kisebb-nagyobb munkákat is végeztettek velük azért, hogy később bekerülhessenek a programba ${ }^{75}$.

A közmunkaprogramban végzett munka során megélt pozitív tapasztalataikat hat kategóriában lehetett csoportosítani; a válaszadók kiemelték, hogy (1) szeretik a közfoglalkoztatásban betöltött munkakörükhöz kapcsolódó tevékenységeket (39\%) „,n̈vényekkel dolgozhatok, imádom csinálni” (35 éves tiszabői nő) -, de sokan (2) a helyi munkalehetőség előnyeit hangsúlyozták (38\%).

„Jó, hogy dolgozhatok, nem csak segélyen vagyok. ",Dolgozhatunk, itt vagyunk helyben, időben kapunk fizetést.” (32 éves tiszabői nö)

Emellett (3) ismerősök között, jó közösségben lehet dolgozni (10\%) és többeknek fontos, hogy (4) munkájukkal tudják segíteni a falu fejlődését, vagy az értékteremtő közmunka során bevételt tudnak teremteni a település számára (8\%). Mind a munkavégzést, mind pedig a tanfolyamon való részvételt többen (5) kikapcsolódásként élik meg (10\%), a képzésen pedig OKJ bizonyítványt is szerezhetnek, és a programnak köszönhetően lehetőség nyílik (6) a családok helyzetének javítására (3\%).

A terepbejárásokon tapasztalt megfigyelések és Tiszabőn készített interjúk alapján elmondható, hogy a közfoglalkoztatottak nincsenek túlterhelve, hiszen bár a közmunkaprogramban dolgozó válaszadók egyharmada szerint sokat kell dolgozni, többségük $(58,7 \%)$ úgy érzi, éppen megfelelő a munka mennyisége. A munkatársak jól kijönnek egymással, hiszen kiemelkedő arányban $(85,2 \%)$ jelezték, hogy egyáltalán 
nincs probléma és vita a kollégák között. A dolgozók többségének $(72,6 \%)$ saját véleménye szerint feletteseik maximálisan elégedettek a közmunkaprogramban végzett munkájukkal, bár egyesek szerint $(14,5 \%)$ a brigádvezetők nem foglalkoznak az elvégzett munka minőségével. A falu közmunkaprogramjában résztvevők 76,6\%-a említette elvárásként a pontos érkezést, viszont a precíz munkavégzést már csak 39,1\%, a munkavégzés során betartandó határidőket pedig csak 29,7\% jelezte követelményként. Emellett 22,2\%-uk említett egyéb olyan elvárásokat, mint a házirend és az utasítások betartását, a tisztaságot, illetve az alkoholtól mentes megjelenést.

Az aktív korú inaktív tiszabői válaszadók közel fele (44,4\%) még egyáltalán nem volt alkalmazásban a nyílt munkaeröpiacon, amely az eredmények tükrében nem meglepő, hiszen $73 \%$-uk nem is keres munkát, 63,8\%-uk pedig még egyáltalán nem jelentkezett munkahelyre. Ennek elsődleges okát a közmunkaprogramban való részvétel jelenti. Az álláskeresés mellőzése és a másodlagos munkaerőpiacon, vagyis közfoglalkoztatásban való munkavállalás között összefüggés fedezhető fel, hiszen azon inaktívak többsége (77,2\%), akik közfoglalkoztatottként az önkormányzat alkalmazásában állnak, egyáltalán nem keresnek munkát. Nem mellékesen érdemes megjegyezni, hogy a közmunkaprogram eredetileg megfogalmazott célját - amely szerint a munkaszocializáció eredményeként visszavezeti a résztvevőket az elsődleges munkaerőpiacra - Tiszabőn nem érte el, hiszen a faluban élő - elsődleges- és másodlagos munkaerőpiacon dolgozó - aktív korúak mindössze 2,6\%-a kapott állást a nyílt munkaerőpiacon a közmunkaprogramban végzett munkájával összefüggésben.

Bár a periférikus jellegü, munkahelyhiányos területeken a közmunkaprogram valódi célját nem az elsődleges munkaerő-piaci integráció, hanem a társadalmi feszültségek csökkentése és a megélhetési nehézségek enyhítése jelenti, a Tiszabőn élő aktív korú, de a nyílt munkaerőpiacon inaktívak 27,4\%-a jelezte, hogy megfelelő elsődleges munkaerő-piaci ajánlat esetén sem tudnának elfogadni egy állást. Ennek okát elsősorban (50\%) az önkormányzattal kötött, határozott idejü közfoglalkoztatási szerződéssel magyarázták.

A dolgozók a közmunkaprogram elsőszámú negatívumaként emelték ki - a feltehetően a kevésbé választhatóság elve ${ }^{76}$ alapján megállapított - az alacsony fizetést (24\%), - ,olyan munka van, amiért több pénz járna” (51 éves tiszabői férfi) -, valamint a szakaszos foglalkoztatás miatt gyorsan véget érő alkalmazási időszakot (5\%), de magas

\footnotetext{
${ }^{76}$ A szociális ellátások rendszerét a kevésbé választhatóság elve szerint alakítják, azért, hogy a többségnek ne érje meg az adott juttatást választani. A koncepció célja, hogy az állam előmozdítsa a munkavállalási motivációt és lehetőleg alacsony szinten tartsa a szociális ellátásokat (ZOMBORI 1997).
} 
arányban (24\%) jelezték negatív tapasztalatként a munkakörülményeket, amely elsősorban az időjárási jelenségek figyelmen kívül hagyását jelenti. Ez a fóliában végzett munkáknál érezhető különös nehézségként.

„Ha nagyon meleg van, akkor is menni kell” (53 éves tiszabői nő)

Emellett a munka stresszel teli jellegét emelték ki, valamint sérelmezték a brigádvezetők kommunikációs stílusát. A közmunkaprogram negatív tapasztalatainak 5\%-át teszi ki az egyes falubeliek igen szük bekerülési lehetőségei, vagyis ,csak az kerülhet be a közmunkaprogramba, aki vásárol húst a képviselötől” (35 éves tiszabői nő), illetve ugyanilyen arányban jelezék a program alacsony szintű szervezettségét (5\%). A legjelentősebb problémát a közmunkaprogramon belüli megkülönböztetés, diszkrimináció jelenti (29\%). A közfoglalkoztatás a szabályai nem minden dolgozóra érvényesek egyformán: „,Kivételt tesznek, hiszen valakinek engedik, hogy hamarabb elmenjen a munkából, akár két hétre is. Mások pedig $H$ betüt kapnak, ha hamarabb hazamennek” (38 éves tiszabői férfi), de a dolgozókkal való - szavazati oldaltól függő különböző bánásmód a beszédstílusban, a munka helyszínében és típusában is megjelenik.

„Az jár kapálni, aki a polgármester ellen szavazott.” (32 éves tiszabői nő) „Nagyon csicskáztatnak, ha nem kapálunk, akkor jön a H betü, levonnak 4 ezret a fizetésböl, vagy kirúgnak.” (32 éves tiszaböi nő)

Emellett a negatív tapasztalatok 9\%-át olyan egyéb körülmények jelentik, amelyek elsősorban nem a közmunkaprogram helyi jellegét kritizálják, hanem annak hátterét jelentő szociálpolitika azon irányváltására utalnak, amely egyrészt a kondicionálásra helyezi a hangsúlyt, vagyis a közfoglalkoztatásban való munkavégzéshez köti bizonyos támogatások kifizetését. Másrészt az aktív foglalkoztatási- és szociálpolitikai eszközöket preferálja a passzívakkal szemben.

„Dolgozni kell.” (41 éves tiszabői nő)

A közfoglalkoztatásban kapható bérek mértékét csak a dolgozók 36\%-a érzi megfelelőnek, viszont a közmunkaprogram pozitív hatásaként értelmezhető, hogy az alacsonynak értékelt közmunkabér ellenére közel minden közfoglalkoztatott $(85,7 \%)$ 
tapasztalta, hogy a másodlagos munkaerő-piaci munkavállalás hatására, tehát a közmunkaprogramban való részvétel eredményeként emelkedett a háztartás bevétele és javult a család anyagi helyzete.

Felmerül a kérdés, hogy lehet-e használni a szegénység kultúrájának és a lakosság jelenlegi munkaerő-piaci helyzetének konzerválására való törekvést egy önkormányzat müködésének vizsgálata során, amely nyilvánvalóan visszaél felruházott hatalmával? A válasz természetesen nem egyértelmü, de érdemes figyelembe venni e gyakorlat lakosság körében kialakult eredményét; a tiszabői emberek már annyira hozzászoktak a dolgok és az ügyintézés ilyen jellegű módjához, hogy számukra ez természetessé vált. Az információtól való elzártság pedig csak növeli az ügyek jelenlegi működésének lakosság körében fennálló legitimitását. A vidéki periférián a közmunkához kapcsolódó munkahelymegtartó képesség - amely szinte az egyetlen helybéli munkalehetőséget jelenti - nem az elvégzett munka minőségétől függ, hanem attól, hogy a jelentkező hajlandó-e szavazatával ${ }^{77}$, vagy vásárlásával bekapcsolódni a falu első embere és a képviselőtestület által müködtetett félfeudális viszonyokat mutató, paternalista jellegü függőségi helyzetet kialakító rendszerbe. És a többség természetesen - egyéb opció híján - integrálódik a rendszerbe, még akkor is, ha „ellenszavazóként” csak a falu szélén jut neki munkalehetőség. Az önkormányzatnak érdeke, hogy a jelenlegi felépítés fennmaradjon, hiszen így az emberek kiszolgáltatottak lesznek az egyetlen lehetséges, állandó jövedelmet biztosító forrásnak. Ezért a településen monopolhelyzetben lévő önkormányzat mindent elkövet, hogy a Tiszabőn élők pénzügyi, iskolai és információval való ellátottságának helyzete stagnáljon, de legalábbis ne emelkedjen. Ezért a tiszabői önkormányzat - hasonlóan az 1991-es Freinet-módszeren alapuló kezdeményezéshez ${ }^{78}$ - hivatalos úton is elkezdte a Máltai Szeretetszolgálat Tiszabőn végzett tevékenységének kritizálását és kezdeményezte visszahívását a településtől ${ }^{79}$, amely szervezet működése potenciális esélyt jelent a helyiek - iskolai, információs és ebből következően pénzügyi - lehetőségeinek fejlődésére.

\footnotetext{
${ }^{77}$ A másodlagos munkaerő-piaci munkahely megtartását a szavazat és az ezért kapott összeg mértéke is befolyásolja. Amennyiben a választópolgár a nyertes jelölttől kapja a „,szavazópénzt”, akkor - bár a nyertes visszafizetteti a szavazatért járó pénzt - annál tovább tud maradni a közmunkaprogramban, minél magasabb a törlesztendő összeg, hiszen annál tovább lehet visszafizetni a kölcsönt.

${ }^{78}$ Az 1980-as évek végétől az 1990-es évek közepéig a tiszabői általános iskolában a diákok egy részét kísérleti jelleggel - reformpedagógiai technikákkal (Waldorf- és Freinet-módszerekkel) tanították, viszont a jelentős eredmények ellenére az önkormányzat befejezte a programot (IMREI 2001, SZEGÖ 2010).

${ }^{79}$ A polgármester az Emberi Eröforrások Minisztériumához fordult annak érdekében, hogy az állam vegye vissza az iskolai fenntartását a Máltai Szeretetszolgálattól (MOLNÁR-RÉVÉSZ 2011).
} 
5.6. A szolnoki Törteli úti szegregátumban élők demográfiája, iskolai végzettsége és jövedelmi helyzete a munkaerö-piaci szerepvállalás aspektusából

A terepen végzett kutatási eredményeim szerint a Törteli úti szegregátumban élők átlagos életkora 22 év, ahol a 18 év alattiak aránya (50,6\%) szinte teljesen azonos a felnőttkorú lakókéval $(49,4 \%)$, tehát a településrész társadalma fiatalodó irányt jelez. A szegregátum lakóinak 63,3\%-a munkaképes (15-64 év) korú, 36,7\%-uk gyermek korban van (0-14 év), viszont a telepen nem él olyan személy, aki átlépte volna a nyugdijjkorhatárt ${ }^{80}$. Az itt élő emberek átlagosan öt fös $(4,94)$ háztartásokban laknak, amely minden ötödik együttélésre mondható el. A kutatás időpontjában a szolnoki telepen élök 46,8\%-a folytatott tanulmányokat, akiknek korábbi befejezett tanulmányait - a torzítások elkerülése érdekében - nem számítottam az eredmények közé. A már befejezett tanulmányokkal rendelkezők egy csekély része egyáltalán nem járt iskolába, míg többségük ugyan elkezdte, de nem fejezte be az alapfokú iskolai képzést ${ }^{81}$. Általános iskolai bizonyítvánnyal a telepen élök több, mint egyharmada rendelkezik, viszont szakmunkásképzö iskolai oklevelet nagyon kevesen szereztek.

13. táblázat - A Törteli úti szegregátumban élök legmagasabb iskolai végzettsége a befejezett tanulmányokkal rendelkezök körében $(N=41)$

\begin{tabular}{|l|c|}
\hline Nem járt iskolába & $2,4 \%$ \\
\hline 8 általánosnál kevesebb iskolai végzettség & $53,7 \%$ \\
\hline 8 általános iskolai végzettség & $36,6 \%$ \\
\hline Szakmunkásképző bizonyítvány & $7,3 \%$ \\
\hline
\end{tabular}

Ez azt jelenti, hogy a szegregátumban nem lakik szakközépiskolát végzett, érettségivel rendelkező, vagy felsőfokú képesítést szerzett személy. Viszont a telepen élők 23,1\%-a szerzett valamilyen szakmai képzettséget iskolai, vagy tanfolyami keretek között. Ezek közül a leginkább jellemző a kőmüves (25\%), a parkgondozó (19\%), a hulladékválogató $(13 \%)$ és a tisztítás-technológus (13\%), valamint a hegesztő, kisgépkezelö, bicikliszerelő, ács és a számítástechnikai karbantartó (6-6\%) képesítés.

A szolnoki telepen található háztartásokban átlagosan egy fö 15 év feletti, befejezett tanulmányokkal rendelkező személynek van önálló keresete vagy rendszeres havi jövedelme (fizetés, szociális juttatás, nyugdíj, stb.). A szegregátum háztartásainak 18,8\%-ában viszont egyetlen rendszeres jövedelemmel rendelkező személy sincs, míg a

\footnotetext{
${ }^{80}$ Ebből adódóan az inaktív kort a Törteli úti szegregátumban élőknél minden esetben a 15 év alatt korosztályra kell érteni. A kutatás időpontjában a legidősebb telepen élő személy 61 éves volt.

${ }^{81}$ Azok a telepen élök, akik elkezdték az általános iskolát, de nem fejezték be, átlagosan 6 osztályt végeztek el.
} 
legtöbb, keresettel rendelkező személy egy háztartáson belül három fő volt (6,3\%). A háztartások 43,7\%-ban legalább egy fő közfoglalkoztatottként dolgozik, viszont együttélések csupán közel ötödében (18,7\%) él olyan személy, aki állandó és bejelentett munkával rendelkezik. Tehát a háztartások 81,3\%-ában egyetlen embernek sincs folyamatos, elsődleges munkaerőpiacon található munkahelye. A közmunkaprogramban való viszonylagosan alacsony részvétel ellenére a háztartások többségben $(68,8 \%)$ nem jogosultak szociális támogatások igénybevételére: 6,3\%-nál egy fö, 18,8\%-nál két fö, míg 8,3\%-nál három személy kaphat szociális juttatást.

A Törteli úti szegregátumban végzett terepi adatfelvétel szerint az ott található háztartások átlagosan havi 137.250 Ft-ból gazdálkodnak, amelyet ha elosztunk az átlagosan öt fős $(4,94)$ háztartásmérettel, akkor látható, hogy egy itt élő ember 27.783 Fttal tud számolni. Ez az összeg 717 Ft-tal alacsonyabb, mint a nyugdíjminimum 28.500 Ft-os összegénél meghúzott szegénységi küszöb, de csak 38,7\%-a az EU-ban elfogadott, a mediánjövedelem 60\%-át figyelembe vevő számításnak, amely 2016-ban $71.800 \mathrm{Ft}$ volt. Az élelmiszerfogyasztás normatív értékét alapul vevő létminimum kalkuláció szerint a szolnoki szegergátumban élők egy före jutó jövedelme a 2016-os évre számított létfenntartáshoz szükséges minimális összeg (88.619 Ft) kevesebb, mint egyharmadát $(31,3 \%)$ érik el. Az eredmények alapján egyértelmüen érzékelhető a telepen élők mélyszegénysége ${ }^{82}$, ahol az egy aktív korúra számított átlagos nettó jövedelem 43.920 Ft.

A rendkívül csekély összeg nem véletlen; a telepen élők elsőszámú bevételi forrása alkalmi munkabérből származik; 17,7\%-uk eseti tevékenységekből, vagy napszámos munkákból él, a szegregátum lakóinak 11,4\%-át foglalkoztatja az önkormányzat a közmunkaprogramban, és csak az itt élők 3,8\%-ának van bejelentett, elsődleges munkaerő-piaci állása. A lakók minimális, 1,3\%-a rendelkezik nem hivatalos munkahellyel, 2,6\%-uk pedig özvegyi, vagy rokkantnyugdíjas, 8,9\%-uk viszont nem tanul, nincs munkája és nincsenek bevételei. A telepiek 6,3\%-a kap gyes-t, gyed-et, gyetet, 7,6\%-uk viszont aktív korúak ellátására (foglalkoztatást helyettesítő támogatás, vagy egészségkárosodási és gyermekfelügyeleti támogatás), vagy egyéb támogatásra jogosult. A telepen élők 46,8\%-a tanuló státuszban van.

Viszont, ha csak az aktív korú (15-64 év) telepiek fö tevékenységét nézzük, akkor látható, hogy 28\%-uk szerez bevételt alkalmi munkákból, 18\%-uk dolgozik a közmunkaprogramban, 8\%-uk pedig nyílt munkaerő-piaci állással rendelkezik, amelyből

\footnotetext{
${ }^{82}$ Magyarországon a mélyszegénység fogalmát arra az egyénre használják, akinek a jövedelme nem éri el az öregségi nyugdíj mindenkori legkisebb - jelenleg 28.500 Ft-os - összegét (CZIBERE 2012).
} 
6\%-uk bejelentett, 2\%-uk pedig nem hivatalos, feketemunkát végez. A szegregátum munkaképes korú lakosainak 4\%-a - nem öregségi - nyugdíjas, míg 14\%-uk nem folytat tevékenységet és nem kap juttatásokat. Az aktív korú telepen élők 10\%-a gyes-re, gyetre, vagy gyed-re jogosult, 12\%-uk pedig szociális támogatásokat, vagy aktív korúak ellátását kap. A 15 és 64 év közötti lakosok 16\%-a tanuló.

Ha pedig kizárólag azokat a munkaképes korúakat helyezem a vizsgálati körbe, akik élethelyzetükből adódóan is képesek a munkavégzésre - nem folytatnak tanulmányokat, nincsenek gyes-en, gyet-en, vagy gyed-en, és nem részesülnek rokkantási nyugdíjban -, akkor látható, hogy a telepen élők 10\%-a tudott elhelyezkedni az elsődleges munkaerőpiacon ${ }^{83}$, míg 90\%-uk a nyílt munkaerőpiac szempontjából inaktív. A kutatás időpontjában az aktív korú inaktívak 24\%-a vett részt a másodlagos munkaerőpiacon található közfoglalkoztatásban, míg a legtöbben $(38 \%)$ többnyire napszámos tevékenységeket jelentő alkalmi munkákat végeztek. Az arány nem meglepő, hiszen interjúalanyom elmondása szerint napszámos munkabér átlagosan duplája egy elsődleges munkaerö-piaci pozícióban megkereshető napi jövedelemnek. Emellett, hivatalos - elsődleges- és másodlagos munkaerő-piaci - munkavégzés esetén a munkabérből automatikusan levonják az esetlegesen felhalmozott tartozásokat, elmaradásokat. A munkaképes korú inaktívak 19\%-a viszont nem végez kereső tevékenységet és nincsenek bevételei, 16\%-uk pedig aktív korúak ellátására jogosult, emellett 3\%-uk özvegységi nyugdíjat kap.

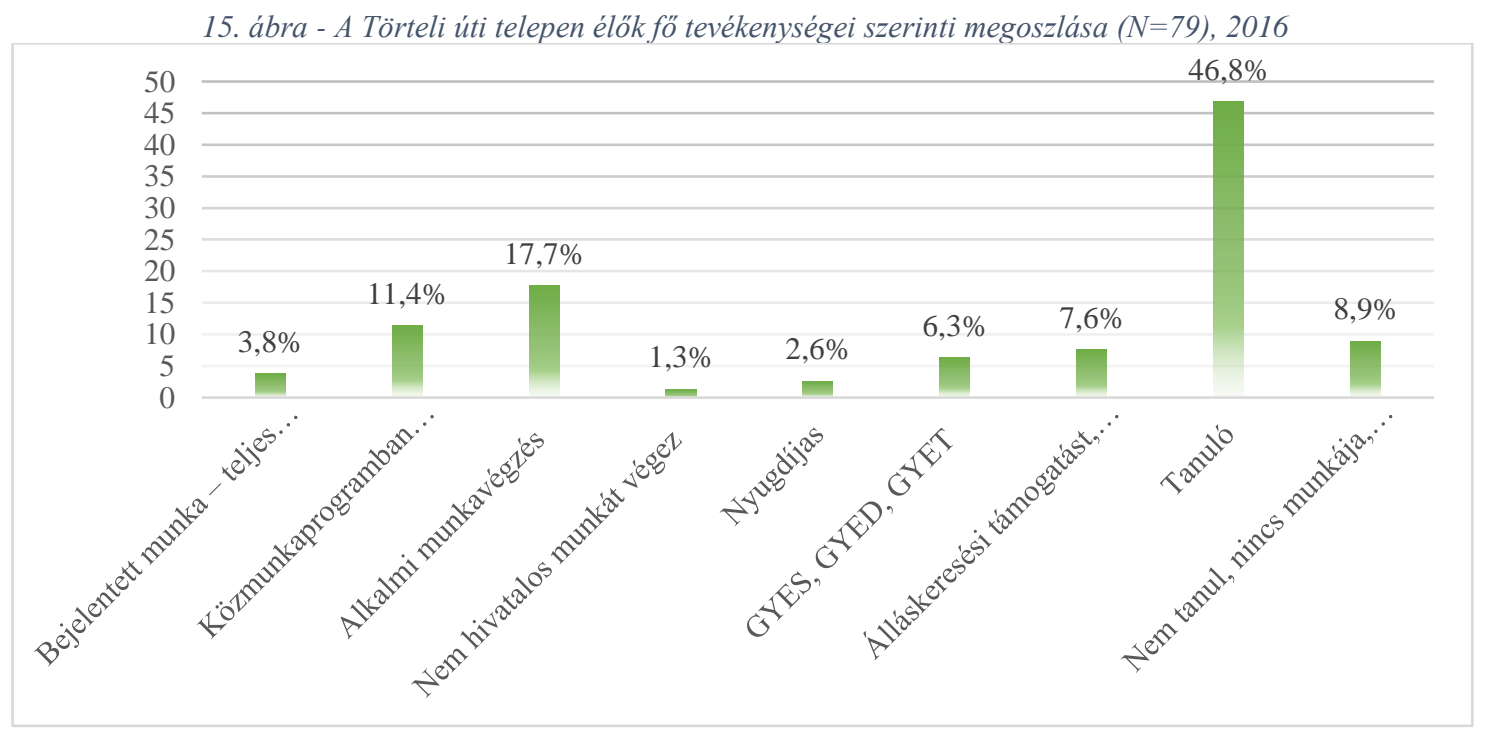

Forrás: saját adatok

${ }^{83}$ Az elsődleges munkaerőpiacon dolgozók 70\%-a dolgozik bejelentett munkahelyen, míg 30\%-uk nem hivatalosan, vagyis feketén van foglalkoztatva. 
Az eredményekből egyértelmüen megállapítható, hogy az elsődleges munkaerőpiacon dolgozó aktív korú telepen élők átlagosan négy évvel (14 év) korábban folytattak először kereső tevékenységet, mint a 15 és 64 év közötti, de jelenleg inaktív lakók (18 év). A centrumhoz közeli periférián élök munkaerö-piaci szerepvállalása és az iskolai végzettsége között nem lehet szignifikáns összefüggést megfigyelni, viszont $a$ nyilt munkaerőpiacon dolgozók többsége (75\%) rendelkezik általános iskolai végzettséggel, és „csak” 25\%-uk nem fejezte be az alapfokú képzést. Ezzel szemben a munkaképes korú - és élethelyzete alapján munkavállalásra alkalmas - telepen élő inaktívak többsége (56,3\%) viszont nem fejezte be az általános iskolát, 34,4\%-uk szerzett alapfokú képesítést, míg 9,4\%-uk szakmunkásképző iskolát végzett. Az elsődleges munkaerőpiacon inaktív csoporton belül a közmunkaprogram dolgozói között a legmagasabb (66,7\%) azok aránya, akik nem fejezték be az általános iskolát, 22,2\% általános iskolai bizonyítványt, 11,1\%-uk pedig szakmunkásképző iskolai oklevelet kapott.

16. ábra - Az aktiv korú Törteli úti telepen élök iskolai végzettsége munkaerö-piaci aktivitás szemszögéböl (N=37),

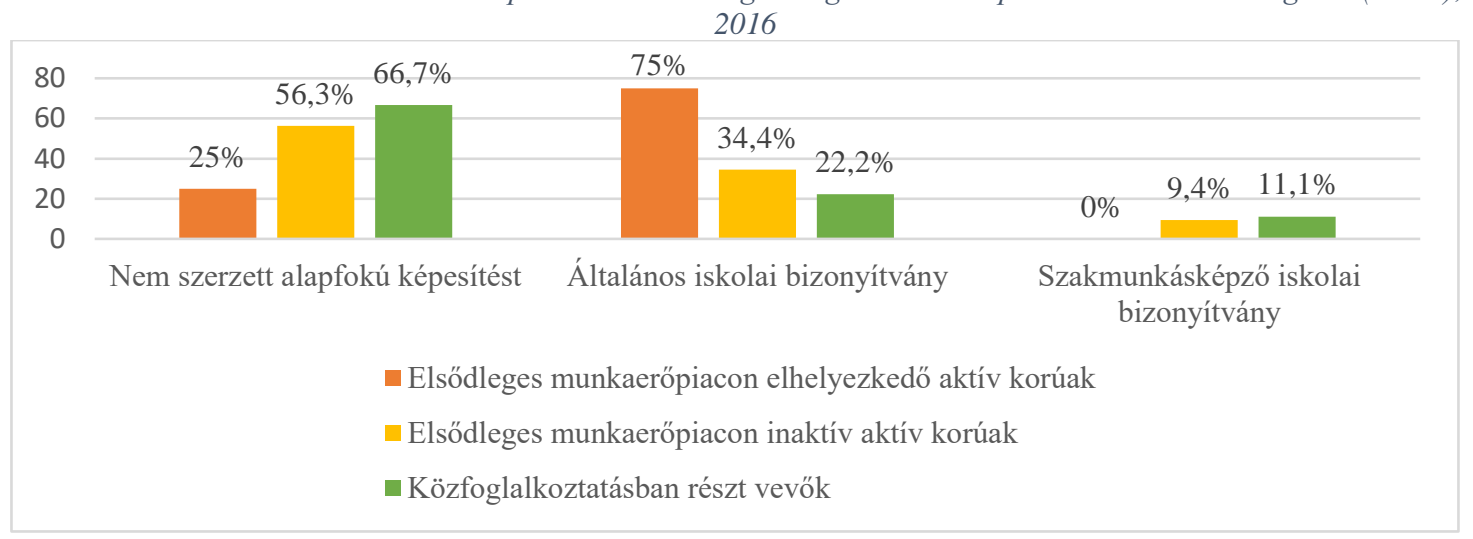

Forrás: saját adatok

Az elsődleges munkaerőpiacon dolgozó telepen élők átlagosan nettó 115.000 Ft-ot kapnak munkájukért, ami a magyar alkalmazásban állók nettó átlagkeresetének (175.009 Ft) 65,7\%-a. A szegregátum lakói az elsődleges munkaerő-piaci pozíciójukkal kifejezetten elégedettek, míg a közfoglalkoztatottak mindössze 20\%-a kedveli a programban átlagosan nettó 62.512 Ft-ért végzett munkáját. Ez az összeg mindössze 54,3\%-a az elsődleges munkaerőpiacon dolgozók átlagfizetésének.

Az elsődleges munkaerőpiacon dolgozók háztartásainak bevétele átlagosan havi nettó $205.000 \mathrm{Ft}$, míg az inaktív háztartások keresete $127.571 \mathrm{Ft}$, tehát csupán $62,2 \%$-a nyílt munkaerőpiacon dolgozók háztartási összbevételének. A telepen élő mindkét munkaerő-piaci csoporthoz tartozók átlagos háztartásmérete ugyanakkora (5 fó), amelyből kiszámolva elmondható, hogy az egy före jutó jövedelem mértéke az 
elsődleges munkaerőpiacon dolgozó háztartásfővel rendelkező együttélések esetében $41.000 \mathrm{Ft}$, míg a nyílt munkaerőpiacon inaktív háztartásokban mindössze $25.514 \mathrm{Ft}$. Tehát a Törteli úti telepen élő, elsődleges munkaerőpiacon dolgozó háztartások a létminimum alatt élnek, az inaktív háztartások egy főre jutó jövedelme viszont a szegénységi küszöböt sem éri el.

5.7. A szegénység kultúrájának hatása a szegregátumban élő hátrányos helyzetűek hosszú távú munkahelymegtartására

A Törteli úti telepen élő munkaképes korúak ${ }^{84}$ fele (50\%) jellemzően csak néhány hónapig dolgozik egy munkahelyen, viszont szintén 50\%-uk több, mint egy évet tölt el egy cégnél. Az aktív korú telepen élőknek eddig átlagosan négy munkahelyük volt, a váltások pedig elsősorban lejáró szerződés miatt történtek, de betegség, és létszámcsökkentés miatt is kellett új állást keresniük az itt élőknek. A leghosszabb egybefüggő munkavégzés átlagosan két év és két hónapig (26 hónap) tartott ${ }^{85}$.

14. táblázat-A Törteli úti telepen élö aktív korúak munkahelyváltásának okai

\begin{tabular}{|l|c|}
\hline Lejáró szerzödés & $75 \%$ \\
\hline Létszámleépités & $12,5 \%$ \\
\hline Egészségügyi probléma & $12,5 \%$ \\
\hline
\end{tabular}

A telepen végzett kutatás eredményei szerint az aktív korúak legfontosabb szempontjai egy munka elvállalásakor a fizetés mértéke (25\%), a munkahelyi és emberi környezet (25\%), de az elvárások és a szabályok jellege (25\%) is befolyásolja a döntésüket. Emellett a munka típusa (12,5\%) is fontos szempont, viszont vannak, akik nem vennének figyelembe semmilyen kritériumot, hiszen - ahogy egy strukturálatlan interjúból kiderült - ,, mindegy, csak munka legyen” (40 éves Törteli úti szegregátumban élő nő). A telepen élők között vannak, akik - saját elmondásuk szerint - nem vállalnának munkát, de olyan személy is található, akinek azért is fontos, hogy legyen keresete, hogy visszakapja gyermekeit állami gondozásból. A szegregátumban élő aktív korúak fele (50\%) jelenleg semmilyen kereső tevékenységből származó bevétellel nem rendelkezik, ők átlagosan több, mint két és fél éve (31 hónapja) folytattak utoljára kereső tevékenységet. A telepen élők legutóbbi munkahelyükön átlagosan nettó 80.571 Ft-ot kerestek, amelynél ha figyelembe vesszük, hogy a kutatást megelőzően (2016.

\footnotetext{
${ }^{84} \mathrm{E}$ fejezetben a viszonylag alacsony elemszám miatt nem választom szét a munkaképes korú (15-64 év) vizsgálati csoportot, viszont a jelenleg is tanulmányokat folytató telepen élőket ez esetben sem vettem vele ${ }^{85}$ Legkevesebb egy hónaptól egészen tíz éven keresztül is meg tudták tartani munkahelyüket.
} 
augusztus) átlagosan két éve és hét hónapja végeztek utoljára kereső tevékenységet, akkor láthatjuk, hogy a 2014-es $155.700 \mathrm{Ft}$-os hazai nettó átlagfizetéshez ${ }^{86}$ viszonyítva pontosan az adott év átlagkeresetének 51,7\%-át keresték meg, amely összeggel a telepen élők több, mint fele (57,2\%) elégedett volt.

A szegregátumban élő munkaképes korú, de elsődleges munkaerő-piaci szempontból inaktívak 45,5\%-a viszont még soha nem végzett hivatalos munkát az elsődleges munkaerőpiacon. A telepen élőknek a többségi társadalomtól eltérő értékek alapján történő szocializációjuk miatt meg kell tanulni alkalmazkodni egy adott munkahelyi környezethez. Ezért nagyon fontos az olyan szociális szakemberek támogatása, akik átadják számukra a munkahelyi rendszerben történő gondolkodást, amelynek keretében el tudják sajátítani a munkakörrel járó kötelezettségeket. Az interjúkból az is kiderült, hogy a periférikus területeken élő hátrányos helyzetűek elsődleges munkaerőpiacra való bekerülésének egyik fő akadálya, hogy a felvételhez szükséges kompetencia-tesztet sokan nem tudják megfelelően kitölteni.

„,...próbáljuk alkalmassá tenni öket a munkára, hogy egyáltalán tudjanak gondolkodni a rendszerben, hogy nyolc órakor be kell jönni...” „Az a probléma az ipari parknál (lévő vállalatokkal), hogy ha még a nyolc osztály meg is van, a kompetencia tesztet nem tudják megcsinálni... Van két-három cég, ami felvállalta a foglalkoztatást, ha az alapkompetenciát legalább meg tudják csinálni.” (Közösségfejlesztő munkatárs 2)

A szakemberek munkájának eredménye is hozzájárulhatott, hogy az inaktív telepen élök legutolsó nyílt munkaerő-piaci pozíciójához tartozó munkaköri feladatok betanulása és a munkahelyi szocializáció is mindegyikük számára könnyen ment. A munkaképes korúak 14,3\%-a korábbi tapasztalataiból már ismerte a feladatokat, 85,7\%-uk pedig gyorsan megtanulta a tevékenységekhez kapcsolódó teendőket, így a határidők teljesítése sem okozott gondot. A válaszadók 42,9\%-a érezte magát túlterhelve legutóbbi, elsődleges munkaerő-piaci pozíciójában. Tehát - a Tiszabőn végzett terepi kutatásomhoz hasonlóan - a szegénység kultúrájában szocializálódott egyénekre jellemző nehéz, új környezetbe történő beilleszkedés nem mondható el a szolnoki szegregátumban élők esetében sem, hiszen a nehézségek nélküli munkahelyi integráció mellett általában több évig meg tudták tartani pozíciójukat egy-egy vállalatnál.

${ }^{86}$ STATISZTIKAI TÜKÖR 2015 
Néhány, kevésbé sikeres munkaerő-piaci integrációs program is kapcsolódik a Törteli úti telephez. Az itt élők közül három embert sikerült delegálni a szolnoki öntödébe, viszont az emberek egy hét után otthagyták a munkahelyüket, mert a hatalmas gépek látványát és a munka által kapott felelősséget - a munkaerőpiactól való hosszú távú távolmaradás és a korábbi munkatapasztalat hiánya miatt - nem tudták megfelelően kezelni. A példa jól mutatja, hogy a szegénység okozta depriváció igen sok területet érint, és a jövedelmi viszonyok mellett az elsajátítható ismeretekre, készségekre és képességekre is kiterjed.

„Delegáltunk három fót, de nem birták egy hétig sem, mert ott olyan gépek vannak, amitöl ök megijedtek, féltek. Ök ilyet nem láttak még és nem tudták, hogy mi az." (Közösségszervező munkatárs 2)

2012-ben egy képzőintézet is tartott szakmai tanfolyamot a Törteli úti telepen élőknek, amely foglalkoztatási, elhelyezkedési lehetőséggel volt összekötve. A program projektkoordinátorával készített interjú során megtudtam, hogy a képzés egy üléshuzatokat gyártó varrodában valósult meg. Mivel a cég munkaerőhiánnyal küzdött, a tanfolyam után szerződéses - vagyis nem közfoglalkoztatáson keresztüli munkaviszonyban alkalmazták volna a résztvevőket. A szakmai oktatás elméleti részét a képzőközpont oktatta, a gyakorlatot pedig a vállalat biztosította azokon a gépeken, amelyeken később a munkavégzés történik. A képzés befejezését követően a tizenöt főből mindössze két ember maradt a munkahelyen dolgozni. A képzettek elmondása szerint nem tudták összeegyeztetni a gyerekek iskolai tevékenységet a munkahely időrendjével, másrészt közlekedési nehézségek is hátráltatták a bejárást, amely a telepről leginkább gyalog volt lehetséges. Harmadik ok a felelősségvállalás és a teljesítményorientáció hiánya volt, amely miatt többségük nem vállalta el a pozíciót. Ez elsősorban abban mutatkozott meg, hogy a tanfolyam ideje alatt a résztvevők számára juttatott megélhetési támogatás nem párosult magas követelményekkel. Azonban a képzést követően a termelésre irányuló munkatevékenységek, és a munkahelyi elvárások már sokkal erősebb korlátozásokat jelentettek a dolgozók számára, amelyek megszegése szankciókkal járt. Ha a munkavállaló késett, vagy nem ment be dolgozni, akkor a vállalat vezetői vagy elbocsátották, vagy jobb esetben a távol töltött idő arányában levontak a fizetéséből. Emiatt a dolgozók igen hamar elveszítették a munkamotivációjukat. A negyedik ok viszont a férjek tiltása volt, akik nem engedték dolgozni a feleségeiket, hiszen egyes kulturális szokásaik szerint a férfiak nehezen élik meg, ha a nők nincsenek 
„felügyelet” alatt. A telepen élőkkel kapcsolatban álló szakemberekkel készített félig strukturált interjúkból kiderült, hogy a szegregátum háztartásaiban megfigyelhető családi normarendszer része, hogy a férfiak egy része nem engedi feleségét, élettársát dolgozni, mivel kulturális szokásaik szerint nem hagyhatják a nők „felügyelet” nélkül. A munkába járás tiltása valójában egy protektív reakció része, amely nem a féltékenységen alapul: egyrészt a férfiak nem szeretnék, hogy a nők a jelenlegitől teljesen eltérő új értékeket ismerjenek meg, amelyek feltehetően vágyakat ébresztenének bennük. Másrészröl pedig ha a jelenleg viszonylag zárt világot alkotó közösségben élő nők a házimunkák - a takarítás, fözés és a gyerekek ellátása - mellett más területen is elismerést kapnak, akkor az új tapasztalat és sikerélmény hatására „kinyílik” az életük, és olyan új életmódokat ismerhetnek meg, amely új mintákkal, normákkal és értékekkel jár. Ezért a férfiak nem nézik jó szemmel, ha a nők iskolába, vagy tanfolyamra járnak, vagy éppen dolgozni kezdenek. Egy kulturális értékrendszer, így a szegénység kultúrája is így tudja védeni és fenntartani magát. Szintén a szegénység kultúrájára jellemző értékrendszer mély beágyazódását mutatja - az interjúalanyok elmondása szerint - a telepen élő szülők gyermekükkel való kapcsolata, amelyre nevelési szempontból a végletek jellemzők: egy részük olyannyira kötődik a gyermekekhez, hogy nem engedik őket elmenni otthonról, mások pedig egyáltalán nem törődnek gyerekeikkel, akik így nagyon szabadon mozoghatnak.

„,Vagy nagyon ragaszkodnak a gyerekeikhez, vagy nagyon elengedik, nincs középút... vagy azt mondják, hogy csinálj, amit akarsz, tizennégy évesen férjhez mész, vagy foggalkörömmel mindenáron megtartják öket és nem engedik, teljesen elvakultan, bezárják." (A telepen dolgozó szociális munkás 2)

Tehát a szülők a nevelésben nem tudnak egy optimális középutat kialakítani, ami miatt a gyerekek vagy nagyon bezárva nevelkednek, amely családok minden programot közösen csinálnak, tehát vagy együtt mennek mindenhová, vagy nem mennek el otthonról. Ennek következtében a szegénység, kirekesztettség újratermelődik, hiszen a gyerekeknek nincs esélyük megfelelő tudást és társas készségeket szerezni.

„A gyerekek oda vannak tapadva az ablakhoz, mert nem engedik ki őket a játszótérre, de ha megjön a családi pótlék, akkor az egész család a kocsmában van. Vagy együtt mennek valahová, vagy sehogy." (A telepen dolgozó szociális munkás 1) 
A másik véglet, vagyis a túl gyenge kötelék hatására viszont felveszik a szegénység kultúrájának jegyeit, vagyis fiatalon összeköltöznek, kábítószert fogyasztanak és kerülik az iskolát.

„A 13-14 éves lányok már nagyon ismerik az életet, van, aki 16 éves és már a második gyereket várja... de be volt drogoztatva." (Törteli úti telepen dolgozó szociális munkás 2)

A telepen élők között kiemelkedően magas arányú kábítószerfogyasztás figyelhető meg, amelynek hátterében is a szegénység kultúrájának egy jellegzetes attribútuma áll: a szegregátumban élők többségének élete a rövid távú haszonszerzésre, az adott pillanatnak élésre épül. A szegénykultúrához kapcsolódó értékek és normák adott szociokulturális környezetben elsajátított mély szocializációs hatását jelzi, hogy az anyagi helyzet javulása nem von egyértelműen magával értékrendváltozást. Ezért ez a kultúra válik a szegénységből és a marginális élethelyzetből való kitörés legnagyobb akadályává. A szegregátumban élő családok közül azok sem szeretnének elköltözni a telepről, akik az átlagos lokális szintnél magasabb életszínvonalat tudnak biztosítani, és képesek lennének egy a centrumhoz közelebbi lakást bérelni. Ugyanakkor a már korábban a telepről elköltözött emberek - felnőttek és gyerekek egyaránt - is különböző okokat keresnek a telepre való visszajárásra. Például nem jelentkeznek át új lakóhelyükre, ezért minden hónapban vissza tudnak menni az esetleges postai küldeményekért a szegregátumba.

„Egyszerüen nincs igényük a változásra és a komolyabb szabályokra... ez nekik jó, megszokott állapot.” (Közösségszervező munkatárs 1)

A szocializáció során kialakult normák, szabályok és értékek között élt mindennapok egy olyan kényelmes helyzetet eredményeznek, amelyben a körülményeikért nem kell felelősséget vállalniuk. A mélyszegénységi lét és az ezzel járó pszichológiai és mentális állapot megváltoztatására pedig igen csekély remény mutatkozik.

„De az alapvető probléma az, hogy ők nem akarnak változtatni, így nincs felelősség, ezért sokkal könnyebb. ” (Közösségszervező munkatárs 2) 
Természetesen a telepen élők szegénység kultúrájához kötődő értékeinek és életkörülményeinek fennmaradása - a már említett - a szegregátum környékén élő és a telepieket irányító személyeknek alapvető érdeke. Hiszen a telepen élők fennálló iskolázottági és pénzügyi helyzetében az elzártság és a tájékozatlanság miatt nincs esélyük a szellemi és anyagi fejlődésre. Ilyen körülmények között pedig könnyen el lehet nekik adni kábítószert és uzsorakamatra tudnak nekik pénzt „kölcsönözni”. A tartozások miatt el pedig elveszik a bankkártyájukat, amelyet - a többnyire szociális juttatásokból, vagy közmunkabérből álló jövedelemmel együtt - ezután ők kezelnek ${ }^{87}$. A hitelek miatt kialakult függő helyzet folytán többnyire a telepet „irányító” személyek engedélye is szükséges egy-egy képzésben vagy projektben való részvételhez, vagyis ezen illetők korlátozó döntései is hozzájárulnak a szegénység kultúrájának telepen való továbbéléséhez.

5.8. A centrumhoz közeli periférikus területek földrajzi és infrastrukturális jellemvonásainak munkaerö-piaci hatásai

A nyílt munkaerőpiacról kiszoruló munkaképes korban lévő telepen élők 38\%-a érzi, hogy nincs lehetősége elhelyezkedni az elsődleges munkaerőpiacon. Ennek okai között szerepel a területi elzártság, a közösségi közlekedés biztosította feltételek és a gyermekek elhelyezésének nehézségei is.

„Messze vannak (a lehetséges munkahelyek), mindentöl elzárva (vagyunk).” (43 éves Törteli úti telepen élő nő)

Azok a szegregátumban élő hátrányos helyzetűek, akik látnak lehetőséget a munkavállalásra, elsősorban betanított gyári munkában, vagy takarítói munkakörben tudnának dolgozni, de a munkaügyi központ által ajánlott közfoglalkoztatás elhelyezkedési lehetőségeit is ismerik. Az aktív korú telepen élők 87,5\%-a tudott jelenlegi, vagy legutóbbi pozíciójában helyben, Szolnokon elhelyezkedni, míg 12,5\%-uk külföldön (Németországban) kapott állást. Azok, akik már legalább egyszer sikeresen el tudtak helyezkedni az elsődleges munkaerőpiacon, vagy jelenlegi is ott dolgoznak, 71,4\%-uk gyalog, 14,3-14,3\%-uk pedig kerékpárral, vagy autóval jár/járt - a külföldi

$87 \mathrm{Az}$ interjúalanyom elmondása szerint, mielött a különböző transzferjövedelmek banki átutaláson keresztül érkeztek, az uzsorások a posta előtt várták meg, míg a segélyezettek felvették a támogatásokat, így azt azonnal el tudták tőlük venni. 
állásokat nem számítva - átlagosan 6,1 kilométerre található munkahelyére, amely 45 percet vett igénybe. Hasonló arány figyelhető meg a közmunkaprogramban résztvevő telepen élők között is, akiknek 77,8\%-a járt munkahelyére gyalog, 22,2\%-uk pedig kerékpárral érkezett. A periférikus területekre jellemző közösségi közlekedés infrastrukturális nehézségei a centrumhoz közeli, urbánus periférián is jelentkeznek, amely az aktív korúak közlekedési szokásaiban megmutatkozik meg, hiszen a szolnoki közösségi közlekedést egyetlen telepen élő sem választotta a munkába járás eszközeként.

A telepen élö közfoglalkoztatottak és munkanélküliek számára is kiemelt fontosságú helyszín a szolnoki Észak-Alföldi Regionális Munkaügyi Központ (17. ábra, $B$ pont), amely 3,5 kilométerre található a Törteli úti szegregátumtól (17. ábra, A pont).

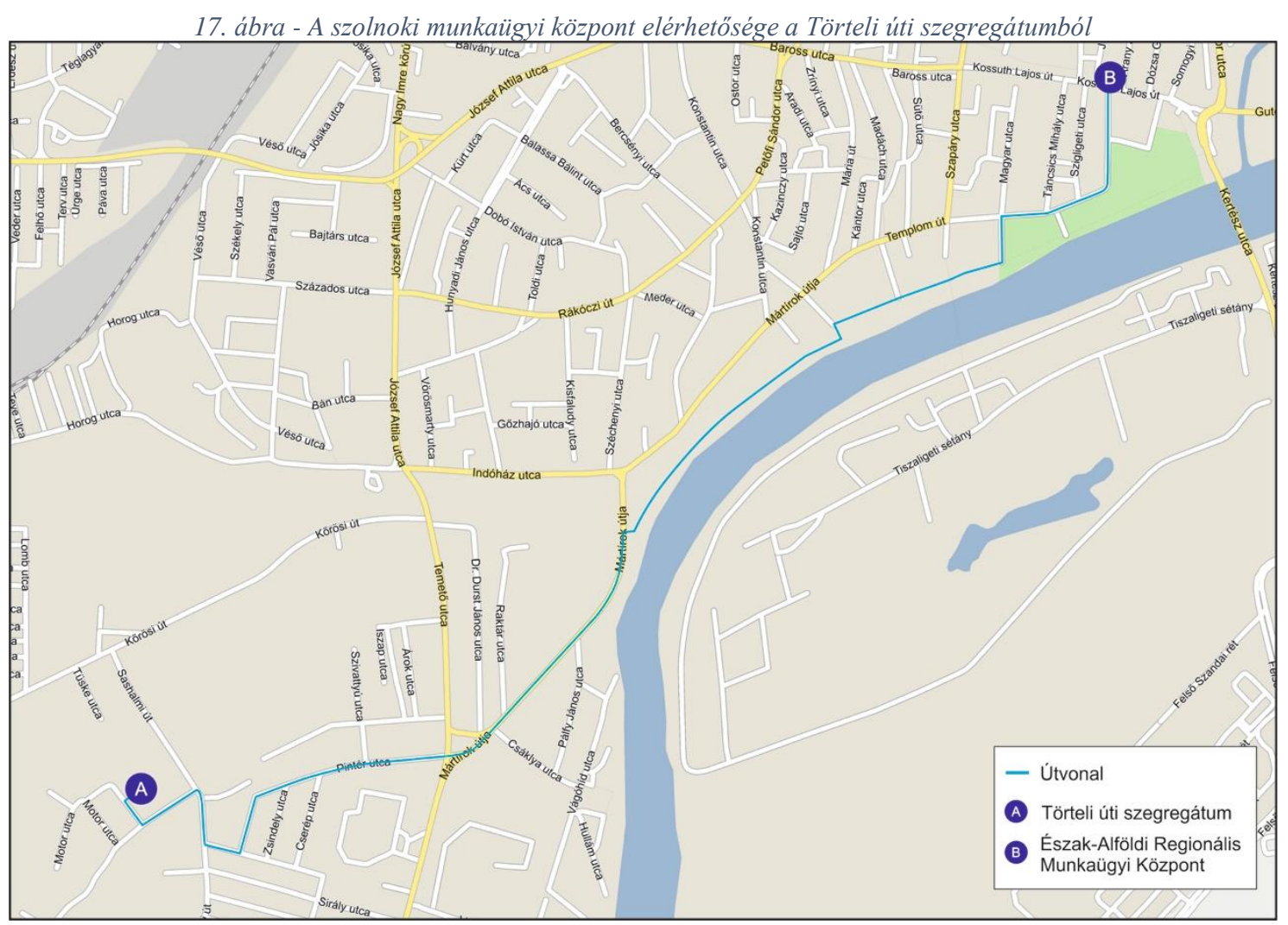

Szerkesztette: DR. DUDÁS GÁBOR éS ROZGONYI-HORVÁTH ÁDÁM

A hivatal személyes felkeresése az érintettek háromnegyedének (75\%) nem jelent problémát, mégis az inaktívak kapcsolattartása a munkaügyi központtal inkább gyengének mondható. A legtöbbjük (50\%) csak a közmunkaprogramhoz kapcsolódó szerződés lejártakor, illetve álláskeresőként a kötelező személyes megjelenések alkalmával keresi fel a kormányhivatal foglalkoztatási főosztályát, és csak 16,7\%-uk tart kapcsolatot az elöírt megjelenések között. Emellett az érintettek egyharmada (33,3\%) semmilyen kapcsolatot nem tart a munkaügyi központtal. A városi periférián élök közösségi közlekedési lehetőségeit jól mutatja, hogy a Törteli úti szegregátum és a 
Szolnok belvárosában található munkaügyi központ közötti távolság ${ }^{88}$ gyalog átlagosan 43 perc alatt teljesíthető, de közösségi közlekedéssel is legalább 35 percet vesz igénybe, amely út során közel két kilométert $(1850 \mathrm{~m})$ mindenképpen gyalog kell megtenni ${ }^{89}$. Emellett a mind időben (8 perc), mind pedig távolságban (1650 m) mérhető előny, amellyel a helyi buszjárat segítené a telepen élöket, a visszaúttal együtt számított 540 Ftos vonaljegy ${ }^{90}$ árával $(2 \mathrm{db})$ terhelné a szegregátum lakóit. Ez alkalmanként az egy telepen élő személyre számított havi jövedelem 2\%-át teszi ki. Azon telepen élők számára, akiknek problémát jelent megközelíteni a kormányhivatalt, a személyes (egészségügyi) probléma mellett az infrastrukturális és a pénzügyi lehetőségek miatt a gyalogos közlekedés nehézségeit emelték ki.

A centrumhoz kapcsolódó periférikus területekre jellemző közösségi közlekedés infrastrukturális és pénzügyi akadályai tehát mind a munkába járását, mind pedig az álláskeresők munkaügyi központba történő eljutását megnehezíti. Ugyanakkor a telepen élők elsősorban éppen e szervezettől várnak segítséget a munkaerő-piaci helyzetükre, hiszen a telepen élő munkaképes korú inaktívak 60\%-a kormányhivatal foglalkoztatási osztályán keresztül igyekszik állást találni ${ }^{91}$. A Törteli úti telepen nyilvántartott álláskeresők arányáról - hivatalos dokumentumok alapján - nincs kurrens információ, viszont a munkaképes korú azon emberek aránya, akik nem tanulók, nem rokkantnyugdíjasok, és nem végeznek munkatevékenységet sem az elsődleges munkaerőpiacon, sem a közmunkaprogramban: 73,5\%. Ez a kutatás idekén mért 4,9\%os országos ráta ${ }^{92} 15$-szöröse. Viszont csak 30,8\%-uk fordít időt munkakeresésre, akiknek 7,7\%-a minden nap próbál munkát találni, szintén 7,7\% hetente, míg 15,4\%-uk havonta néhány alkalommal próbál elhelyezkedni. Az aktív korú inaktívak átlagosan nettó 93.500 Ft-ért fogadnának el egy állást az elsődleges munkaerőpiacon. Kétharmaduk $(66,7 \%)$ legfeljebb átlagosan 51,6 kilométer távolságra ${ }^{93}$ az ingázást is vállalná, sőt $18,2 \%$-uk olyan munkát is végezne, ahonnan csak hetente tudna hazajárni.

\footnotetext{
88 A távolság és idő számítását a maps.google.hu oldal segítségével mértem, amely a legrövidebb gyalogosan elérhető utat számítja, a közösségi közlekedéssel történő utat pedig a helyi, Középkeletmagyarországi Közlekedési Központ Zrt. (KMKK) hivatalos menetrendje alapján méri.

${ }^{89}$ A Törteli úti telephez legközelebbi megálló 1100 méterre található és a leszállás után is további 750 métert kell sétálni.

${ }^{90}$ KMKK.HU

${ }^{91}$ Személyes, vagy telefonos megkereséssel 40\%-uk, családtagok, rokonok, vagy ismerősök segítségével, tehát kapcsolati tőkéjük szintén 40\%-uk próbál elhelyezkedni. Az eredmények szerint sem újsághirdetésen keresztül, sem pedig internetes csatornán nem keresnek munkát, amely elsősorban ezen eszközök hiányával, vagyis objektív relatív deprivációval (TOWNSEND 1979) magyarázható.

92 KSH 2016A, STATISZTIKAI TÜKÖR 2017

93 A közmunkaprogramban dolgozó telepen élök átlagosan 86.600 Ft-ért vállalnának állást az elsődleges munkaerőpiacon, és átlagban 52,5 km-t hajlandók ingázni a munkahelyükre.
} 
5.9. Területi stigma és a kapcsolati tőke hatása a centrumhoz közeli periférikus területeken élők munkaerö-piaci szerepvállalására

A munkaképes korú telepen élők 85\%-a szerint nehezebb a Törteli úti szegregátum lakójaként munkát találni, mint a Szolnok más városrészében élő embereknek.

„Kimondjuk, hogy Törteli, és vége!” (36 éves Törteli úti telepen élő nő)

A helyiek szerint a szegregátumhoz kapcsolódó sztereotípiák Szolnokon kialakult jelenlétét elsősorban az itt élők egy csoportjának deviáns viselkedése okozza.

„Vannak itt olyanok, akik lopnak, és emiatt azt gondolják, hogy mindenki lop.” (22 éves Törteli úti telepen élő férfi)

$\mathrm{Az}$ egyes szolnoki foglalkoztatók körében is megfigyelhetö, lakóhely szerinti diszkriminációt a telepen élőkkel foglalkozó szociális szakemberekkel készített interjúk is alátámasztották. A területi stigma nincs összefüggésben a nemzetiségi alapon történő hátrányos megkülönböztetéssel, hiszen interjúalanyom szerint azok a telepen élők is lakóhelyük elmondása után kaptak visszautasítást egy adott munkahelyen, akik külső, antropológiai jegyeik alapján nem sorolhatók a roma társadalomba.

„....ha megmondják egy munkahelyen, hogy telepi, az plusz egy stigma... ezért csak olyan foglalkoztatásban tudnak elmenni, ami közcélú.” (Közösségszervező munkatárs 1)

Tehát a centrumhoz közeli periférikus területekre jellemző területi stigma is hátráltatja az itt élők elsődleges munkaerőpiacon való elhelyezkedését. A megbélyegző gondolkodás kiterjedtségéről nem sikerült pontos képet kapni, de Szolnok egész területét érinti. Az aktív korú Törteli úti lakosok 58,3\%-ának munkára jelentkezését utasították már el a telepet érintő területi stigma miatt, és 41,7\%-uk tapasztalt már cigány származásához kapcsolódó hátrányos megkülönböztetést. A telepet érintő megbélyegzés és a nemzetiségi diszkrimináció elsősorban a munkára történő jelentkezések során jelent nehézséget a szegregátumban élőknek, hiszen munkavégzés közben mindössze 10\%-uk számolt be diszkriminatív megkülönböztetésröl. Az elsődleges munkaerö-piaci pozíciók megszerzésében a centrumhoz közeli periférikus területen élőket elsősorban a munkaügyi központ segíti, hiszen az aktív korúak 87\%-a találta jelenlegi, vagy legutóbbi 
munkahelyét a kormányhivatal közvetítésével. Emellett mindössze 12,5\%-uk talált állást kapcsolati tőkéjének segítségével, tehát családtag, rokon, vagy ismerős közbenjárásával.

5.10. A közmunkaprogram hatása a szegénység kultúrájára és a hátrányos helyzetűek elsődleges munkaerö-piaci integrációjára

A telepen élő munkaképes korú inaktívak mindössze 38,5\%-a dolgozik a közmunkaprogramban, vagyis a telepen élő összes munkaképes korú ember 18\%-a vesz rész Szolnok közfoglalkoztatási programjában, akiknek átlagéletkora a kutatás időpontjában 41,1 év volt ${ }^{94}$. A telepen élő legfiatalabb közfoglalkoztatott 28 éves, a legidősebb pedig 59 éves volt. Természetesen minden közfoglalkoztatott a szolnoki munkaügyi központon (kormányhivatal foglalkoztatási főosztály) keresztül került a programba, amelybe történő bekerülés gyakoriságában és hosszában nincs jelentős eltérés a telepen élők körében. A közfoglalkoztatottak átlagosan öt alkalommal kerültek be újra a programba, és a kutatást megelőző egy évben átlagban tizenegy hónapot voltak napi nyolc órás alkalmazásban ${ }^{95}$. A közmunkaprogramban dolgozó telepen élők nem éreztek semmilyen megkülönböztetést a bekerülési folyamat során, viszont a jelenleg is közfoglalkoztatásban lévők 44,4\%-nak jelentkezését utasították már el, elsősorban egészségügyi alkalmatlanságra, a felvehető emberek korlátozott számára és a felvételi időszak lezárulására hivatkozva.

„Azt mondták nincs felvétel.” (19 éves Törteli úti telepen élö férfi)

A közmunkaprogramban végzett feladatok mindegyike betanított munka: nyáron a parkgondozást, városrendezést és utca takarítást végeznek, télen pedig a hó eltakarítása és a járdák jégtelenítése kapcsolódik tevékenységükhöz. Ezeket a feladatokat mindössze egyötödük (20\%) szereti. A program legfontosabb pozitív tapasztalatai közé tartozik, hogy jó közösségben tudnak dolgozni (14,5\%), és esetenként kedvelt tevékenységhez is kapcsolódik (14,5\%) a munkavégzés. A legfontosabb pozitívum a résztvevők számára (71\%) maga a tény, hogy a közfoglalkoztatás munka- és megélhetési lehetőséget teremt számukra. A szolnoki közmunkaprogramban dolgozók valamelyest túlterhelve érzik magukat, hiszen 77,7\%-uk szerint sokat kell dolgozni és csak 22,3\%- érzi, hogy éppen

\footnotetext{
${ }^{94}$ Azok az inaktívak, akik jelenleg nem vesznek részt a közmunkaprogramban, 57,1\%-uk korábban már dolgozott közfoglalkoztatottként, utoljára átlagosan másfél éve (18 hónapja), átlagosan összesen három és fél évet.

${ }^{95}$ Legkevesebb hét hónapot, leghosszabban pedig tizenkét hónapon keresztül voltak foglalkoztatva.
} 
megfelelő a munka mennyisége. Viszont a munkatársak között egyáltalán nincsenek viták, és az összes telepen élő közfoglalkoztatott úgy érzi, feletteseik elégedettek a munkájuk minőségével. A szolnoki közmunkaprogramban dolgozók 62,5\% jelezte alapvető elvárásként a precíz munkavégzést, viszont a pontos érkezést már csak $25 \%$-uk említette követelményként. Érdekes, hogy a kiadott feladatok határidejének tartásáról egyikük sem számolt be elvárásként, viszont 25\%-uk szerint nem lehet elhagyni a munkaterület, kötelezö elöírás a munkaruha viselete $(12,5 \%)$ és elengedhetetlen az alkoholtól mentes megjelenés (12,5\%).

A telepen élő emberekkel foglalkozó szociális szakemberek az interjúk során elmondták, hogy korábban, a szervezetüknél a közfoglalkoztatás keretében dolgozó telepiek a munkavégzés során képesek voltak megtanulni a feladatokat és alkalmazkodni a munkahelyi körülményekhez. A munkavégzésnek köszönhetően pedig megtapasztalták, hogy a jelenlegi körülményeiknél többet is képesek elérni, és egy idő után kialakult az igényük a telepről való elköltözésre.

„, Szépen felépülnek, és felfogják, hogy ők már nem azon a szinten vannak, mint a többiek, akkor máshol lakást igényelnek.” (Közösségfejlesztő munkatárs 1)

A szociális szakemberek igyekeznek támogatni a motiváltabb emberek telepröl való elköltözését. Viszont - az interjúk során kapott információk szerint - a telepen tanult szocializáció és a megszokott életforma miatt a szegregátumból elköltözők jelentős része visszavágyik a telepre.

„Lehet, hogy most testben ott laknak (az új helyen) de lélekben még mindig a telepen vannak... és nem tudnak, vagy nem akarnak szabadulni ettől.” „,Nem tud beilleszkedni az új környezetbe." (Közösségfejlesztö munkatárs 2)

A munkaképes korú telepen élő inaktívak közel fele (45,5\%) még egyáltalán nem volt foglalkoztatva a nyílt munkaerőpiacon, amely persze nem véletlen, hiszen 69,2\%uk jelenleg nem is keres munkát, 44,4\%-uk viszont még soha nem jelentkezett munkahelyre. Ezek az eredmények visszavezethetők a közmunkaprogramban való munkavállalásra, hiszen a jelenleg közfoglalkoztatottként az önkormányzat alkalmazásában álló inaktívak közül egyikük sem keres munkát. Így nem meglepő, hogy a közmunkaprogram a szolnoki szegregátum esetében nem érte el eredeti, elsődleges munkaerő-piaci (re)integrációs célját, hiszen a telepen élők közül egyetlen korábbi, vagy 
jelenlegi közfoglalkoztatott sem kapott állást a nyílt munkaerőpiacon a programban végzett munkájának eredményeként. A közmunkaprogramhoz kapcsolódó negatív tapasztalatok közé sorolható, hogy az egyes tevékenységeket (például gyomlálás) többen nehéznek érzik, és a kedvezőtlen munkakörülmények (például magas virágpor koncentráció) ellenére alacsony fizetést kapnak a dolgozók. Mindemellett a közfoglalkoztatásban végzett munkáért kapott bér mértékét a dolgozók 55,5\%-a megfelelőnek érzi és $87,5 \%$-uk tapasztalta, hogy a másodlagos munkaeröpiacon való munkavégzés eredményeként javult a család anyagi helyzete.

\section{6. Összegzés és következtetések}

A disszertáció utolsó fejezetében elsőként a kutatás kérdései kerülnek megválaszolásra a választott mintaterületeken kapott eredmények alapján. Majd az eredmények hasznosításának lehetőségeit fejtem ki, javaslataimmal kiegészítve; különös tekintettel a gyermekkori felzárkóztatás, az iskolai integráció és munkavégzéshez szükséges kompetenciák fejlesztésének területén. A fejezetet és egyben a dolgozatot a periférikus területek általam vázolt várható jövőképével zárom.

\subsection{A mintaterületek összehasonlítása a kutatási kérdések tükrében}

A célterületeken végzett kutatás alapján elmondható, hogy a periférikus területeken élő hátrányos helyzetűek átlagos életkora mindkét mintaterületen jóval a magyar társadalom átlagéletkora, vagyis 42 év (KSH 2017) alatt van. Ennek természetesen okai között szerepel a szegénység kultúrájának értékrendjében meghatározó norma, a gyermekkorban elkezdődő nemi élet (TOWNSEND 1979) és az ebből adódó korai gyermekvállalás, amely hatással van a periférikus területen élők iskolai végzettségének alacsony szintjére. A szocializáción keresztül erre éppen a szülők nevelik gyermekeiket, amely már az óvodai szerepjátékok során is megmutatkozik, ahol maguk által kezdeményezve, gyakran eljátsszák a szülés folyamatát (SZVF 2017). A periférikus területeken élő gyerekek már egészen korán - általában a közvetlen lakókörnyezetből választva társat - létesítenek párkapcsolatot, emiatt fiatalon, általános iskolai végzettség megszerzése nélkül kerülnek ki az oktatási rendszerből. Az alacsony átlagéletkort emellett olyan lokális faktorok is okozhatják, mint a gyógyszertár és az egészségügyi szolgáltatás hiánya, a szenvedélybetegségek jelenléte, vagy éppen a lakókörnyezet 
egészségkárosító hatásai. Tiszabőn elsősorban a helyben elérhető közszolgáltatások hiánya és a területi stigma okoz problémát, hiszen a lokálisan nem elérhető állandó orvosi jelenlét és a sürgősségi ellátás ellenére a szomszédos Fegyverneken sem látják el a falubelieket. A Törteli úti szegregátumban élők egészségügyi ismereteinek alacsony szintje, a háziorvos felöl érzett odafigyelés hiánya, és a már gyermekkorban megfigyelhető minőségi alultápláltság mellett a lakások vizes falai, a kedvezőtlen higiénés feltételek és komfort nélkül épített ingatlanok - elsősorban a folyóvíz nélkülözése -, valamint az addiktív szerek - alkohol, kábítószer és dohányzás - jár fokozott egészségügyi kockázattal. Az alacsony átlagéletkor egyben fiatalodó társadalmat is jelent, amely általában együtt jár a munkaképes korúak magas arányával, a periférián élők körében viszont a gyermekkorúak kiemelkedően magas aránya jellemzö ${ }^{96}$.

A kutatás eredményei szerint az iskolai végzettség szintjének emelkedése pozitívan befolyásolja a periférikus területeken élők elsődleges munkaerő-piaci integrációját. A vizsgált területeken az elsődleges munkaerőpiacon elhelyezkedők iskolai végzettsége és háztartásuk bevétele volt a legmagasabb, és a közmunkaprogramban dolgozók iskolázottsága és háztartásuk bevétele volt a legalacsonyabb. Ez alátámasztja az iskolai végzettség munkaerőpiacra gyakorolt hatását, valamint bizonyítja, hogy a közmunkaprogram elsősorban a legrosszabb munkaerö-piaci tulajdonságokkal rendelkezők számára kínál lehetőségeket (TÉSITS et al. 2015).

„A közfoglalkoztatásban nem kérdezik meg, hogy hány osztályuk, vagy milyen képzettségük van, bárki söprögethet az utcán.” (Közösségfejlesztő munkatárs 1)

A területi különbségeket figyelembe véve a vidéki periférián élők magasabb az iskolai végzettséggel rendelkeznek, amely magasabb arányú elsődleges munkaerö-piaci szerepvállalással is párosul. Emellett egyértelműen megmutatkozik, hogy a munkaerőpiaci szerepvállalásra pozitívan ható tényezők közül kiemelkedik a minél fiatalabb korban lévő első munkavállalás is. Regionális viszonylatban, a város és vidék relációjában a rurális, belső periférikus területeken némileg magasabb az elsődleges munkaerő-piaci aktivitás aránya a centrumhoz kötődő, magterülethez közeli városi periférikus területen élőkhöz képest. Természetesen a nyílt munkaerő-piaci pozícióhoz magasabb jövedelem is kapcsolódik, ezért a tiszaböi háztartások összbevételében

\footnotetext{
${ }^{96}$ A kutatás időpontjában hazánkban 100 gazdaságilag aktív korú (15-64 év) személyre átlagosan 49 inaktív korú jutott (KSH 2017), amely Tiszabőn 62 fö, a szolnoki szegregátumban pedig 58 fö volt.
} 
magasabb arányt alkot a fizetésből származó kereset, mint a telepi együttélések esetében. Ez az egy före jutó jövedelem mértékére is pozitívan hat, ami a vidéki periférikus területeken élők esetében magasabb - viszonylagos - jóléti szintet feltételez.

Megállapítható, hogy a szegénység kultúrájának lokális szinten vizsgált attribútumai - a munkahelyi környezethez és idökerethez alkalmazkodás nehézsége, rövid távra tervezés - nem akadályozzák a periférikus területeken élő hátrányos helyzetủek hosszú távú munkahelymegtartását. Viszont látható, hogy a munkahelymegtartó képesség összefüggésben van a jelenlegi munkaerő-piaci státusszal, hiszen a nyílt munkaerőpiacon dolgozók között nagyobb arányban figyelhető meg hosszú távú munkahelymegtartás. Ugyanakkor a munkaerö-piaci szerepvállalás visszavezethetö az iskolai végzettségre, tehát kijelenthető, hogy minél magasabb képzettséggel rendelkezik egy munkavállaló, annál hosszabban lesz képes megtartani munkahelyét. Ezzel szoros összefüggésben, a területi különbségek alapján egyértelműen elmondható, hogy a vidéki periférián élők erősebb munkahelymegtartó képességgel rendelkeznek. Körükben magasabb a hosszú távú munkavállalás, a leghosszabb munkahelymegtartás pedig közel háromszoros időtartamot jelez, mint a centrumhoz közeli, városi periférián élők esetében, amely a nyílt munkaerőpiacon tapasztalható magasabb fizetéssel és elégedettebb munkavégzéssel függhet össze.

Ennek ellenére a tiszabői lakosokkal folytatott és a szolnoki telepen élőkkel kapcsolatban álló segítő foglalkozású személyekkel készített interjúk alapján elmondható, hogy a szegénység kultúrája mindkét vizsgálati térségben jelen van, amely legföképp a kizárólag rövid távra tervezésben mutatkozik meg. A szegénykultúra érték- és normarendszere elsősorban az urbánus periférián élő hátrányos helyzetűek hétköznapjait és családi életét szövi át mélyrehatóan. A periférián élők a jól megszokott, helyi szinten kialakult szabályok miatt tartanak minden változástól, ezért folyamatos motiválásra és támogatásra van szükségük, hogy képesek legyenek megváltoztatni helyzetüket.

Az eredmények alapján látható, hogy a periférikus területek földrajzi, területi jellemvonásai és a hozzá kapcsolódó közösségi közlekedés infrastrukturális nehézségei negatív hatással vannak az ott élő hátrányos helyzetűek elsődleges munkaerő-piaci jelenlétére. E körülmények elsősorban az inaktívak számára jelentenek problémát, hiszen munkaügyi központ/kormányhivatal megközelíthetősége közösségi közlekedéssel igen nehézkes, és esetenként a költségeit sem tudják megfizetni. Ugyanakkor mind a vidéki, mind pedig a városi perifériák lakói legfőként a munkaügyi központtól várnak megoldást munkaerő-piaci helyzetükre. Viszont a munkaügyi központ - elsősorban a 
tiszabőieket érintő, a közfoglalkoztatási szerződés folyamatos megújítására irányuló gyakorlatával a periférikus területeken élők munkaerő-piaci helyzetének és munkanélküliségi rátájának kizárólag a konzerválására van lehetőség. Ennek is köszönhetően, hivatalos adatok szerint a tiszabői munkanélküliség - a kutatás idején az országos átlag kétszerese volt, addig - nem hivatalos eredmények szerint - a Törteli úti telepen mérhető inaktivitás az országos ráta tizenötszörösét jelezte. Természetesen ezen magas arányokhoz nem csak a munkaügyi központ - a periférikus területeken élők elmondásai alapján jellemezhető - gyakorlata járul hozzá, hanem az elsődleges munkaerő-piaci szempontból inaktívak alacsony munkakeresési motivációja is a jelenlegi helyzetet stabilizálását segíti, amelyet a közmunkaprogramban való munkavállalás tovább mérsékel.

A kutatás eredményei szerint a rurális jellegű periférikus térségek területi és infrastrukturális jellemvonásai akadályozó tényezőként hatnak az ott élő hátrányos helyzetűek elsődleges munkaerő-piaci jelenlétére. A területi elszigeteltség és a közösségi közlekedés hiányai - a rurális területeken - főként a kötelezö, munkaügyi központban, vagy kirendeltségen történő személyes megjelenést és a közfoglalkoztatási szerződés megújításához szükséges regisztrációt hátráltatják. A közösségi közlekedés korlátozott megjelenése a centrumhoz kapcsolódó periférián élők munkába járását is nehezíti, de az álláskeresők kormányhivatalba történő eljutását is hátráltatja.

A kutatás során egyértelmüen kirajzolódott egy, a periférikus területeken élők hétköznapjaira és munkaerő-piaci szerepvállalásukra is kedvezőtlenül ható, mindkét vizsgálati területre jellemző területi stigma. A területi alapon történő megbélyegzés a vidéki periférián élők esetében az egész megyére kiterjed, a szolnoki szegregátum esetében pedig a város területét érinti, vagyis mindkét periférikus terület esetében az elsődleges munkaerő-piachoz kapcsolódó foglalkoztatási övezetre terjed ki. A területi stigma egy olyan diszkriminációval jár, amely megnehezíti az adott területen élők mindennapjait, hiszen mind munkaerö-piaci, mind kereskedelmi területen nehézségeket jelent a megbélyegzett területi egységben élők számára, de egyes esetekben a közszolgáltatások igénybevételét is hátráltatja.

A periférikus területeket övező térségekben élők sztereotip, megbélyegző mentalitását mindkét terület esetben a stigmatizált területeken élők egy csoportjának deviáns viselkedése váltja ki, illetve a Tiszabő esetében jellemző, szélesebb kiterjedést a falu gyakori - elsősorban negatív tartalmakkal telt - médiaszereplése eredményezi. Az elsődleges munkaerö-piaci foglalkoztatók megbélyegző gondolkodása pedig az alkalmi munkavállalás és a közfoglalkoztatás irányába vezeti a hátrányos helyzetüeket, amely 
tartósítja a körülményeiket. A területi stigmához kapcsolódó sztereotip gondolkodás elsősorban a vidéki periférián élők esetében - a munkaerőpiac mellett a közszolgáltatások (hivatali ügyintézés, egészségügy) és a kereskedelem (banki szolgáltatás) területén is érezteti hatását. A területi stigma nem azonos az etnikai, nemzetiségi alapon történő hátrányos megkülönböztetéssel, de átfedések tapasztalhatók a diszkrimináció e két változata között. Az eredmények szerint a periférikus területekre jellemző területi stigma sokkal nagyobb mértékben hátráltatja a hátrányos helyzetủek munkavállalását, mint a származás alapján történő megkülönböztetés. Ez utóbbi a centrumhoz közeli periférián élők elhelyezkedését akadályozza magasabb arányban. A lakóhely szerinti hátrányos megkülönböztetés spektruma szélesebb a rurális periférián élők esetében, ahol egyrészt a megye teljes területére kiterjed, másrészt a munkaerő-piaci hátrányok mellet a kereskedelmi és a közszolgáltatásokban is jelentős hátrányokat eredményez.

Az elsődleges munkaerő-piaci pozíciók szerzésében a vidéki periférián élők esetében legfontosabb szerepe a kapcsolati tőkének van, míg ezen a téren a városi periférián élők számára a munkaügyi központ jelenti a legnagyobb segítséget. A vidéki periférián a közmunkaprogramban való elhelyezkedésben is fontos szerepet kap a lokális szintű kapcsolati tőke, amelyet a polgármesterrel és a képviselőkkel kialakított kapcsolat minősége határoz meg. Ennek alapját - a helyi válaszadók elmondása szerint - az önkormányzati választásokon leadott szavazat jelenti. A tiszabői közfoglalkoztatáshoz kapcsolódó helyi kiválasztási és müködtetési szisztéma ellenére a közmunkaprogramban való magas részvételi arány nem véletlen, hiszen az ott élők álláspontja szerint az elsőszámú elhelyezkedési és megélhetési lehetőséget a közmunkaprogram jelenti. Ezzel szemben a szolnoki szegregátum lakói legfőképpen a szezonális, alkalmi munkákból szerzett jövedelemre alapozzák egzisztenciájukat.

Területi relációban vizsgálva az eredményeket egyértelmüen látszik, hogy a vidéki periférikus térségben sokkal jelentősebb - arányait tekintve több, mint kétszer akkora - foglalkoztatási szerepet tölt be a közmunkaprogram, mint a centrumhoz közeli, városi periférikus területeken. A rurális periférián tapasztalható magas közfoglalkoztatási arány nem meglepö, hiszen - mindkét célterületen - a hátrányos helyzetűek legutolsó, nyílt munkaerő-piaci pozíciójukkal az adott év hazai átlagának töredékét keresték meg. Ez természetesen - a kevésbé kívánatosság elve miatt - még mindig magas magasabb az aktuális év közfoglalkoztatási bérénél, de a közmunka jellemzően alacsonyabb felelősséggel, elvárással és kötelezettséggel jár, mint egy elsődleges munkaerő-piaci pozíció, ezenfelül helyben elérhetö lehetőséget jelent. 
Egyes vizsgálatok (SCHARLE 2015, TíMÁR ET AL. 2015, CSERES 2015, TÉSITSALPEK 2015) szerint a közmunkaprogram társadalmi haszna, hogy a szociális foglalkoztatást helyettesítő - támogatásoknál magasabb jövedelmet nyújt a résztvevőknek. Ezt kutatási eredményeim is alátámasztják, hiszen közel minden másodlagos munkaerőpiacon elhelyezkedő munkavállaló (Tiszabő: 85,7\%, Szolnok: 87,5\%) tapasztalta, hogy a közmunkaprogramban való elhelyezkedésnek köszönhetően javult a háztartásuk anyagi helyzete.

Természetesen a háztartások pénzügyi körülményeinek javulása nem vonja egyértelmủen magával a szegénység kultúrához kapcsolódó értékek elhagyását, és a másodlagos munkaerő-piaci elvárások sem olyan szigorúak, mint amelyeket nyílt munkaerőpiacon található vállalkozásoknál lehet tapasztalni. Egyes kutatások (SIPTÁRTÉSITS 2014, VELKEY 2014A) a közmunkaprogram pozitívumai között jelzik, hogy a közfoglalkoztatásban végzett tevékenységek hozzájárulnak a tartósan munkanélküli emberek munkaképességének és szakmai kompetenciának fenntartásához vagy kialakításához. Ehhez kapcsolódóan elmondható, hogy a mintaterületeken végzett kutatási eredményeim szerint a pontos érkezés és precíz munkavégzés, mint a két alapvető követelmény jelentős mértékben segíti az időkerethez való igazodást, a szabályokhoz való alkalmazkodást és az elvégzett munka teljességének érzését. Emellett a közfoglalkoztatás kedvezően hat a periférikus területeken élö közfoglalkoztatottak munkahelyi integrációjára, mivel közösségben végezhető pozitív munkatapasztalatot, élményt szereznek és munkafolyamatokat sajátítsanak el. Továbbá a különböző munkakörökben dolgozó közmunkások láthatják munkájuk eredményét, és érezhetik ennek hatását - megtermelt termények szétosztása, általuk készített vályogtéglából épült irattár, általuk font drótból készülő kerítés, valamint a járdalapok felújításával, fák ültetésével és az utcák tisztántartásával szépülő település -, ami esetenként 20-25 év nyílt munkaerőpiacról való kiesés után további pozitív megerősítést jelenthet számukra és befolyással lehet egy későbbi munkavállalás kimenetelére. Ezek hatására, és a közfoglalkoztatásban megszerzett napi munkarutin és munkarend kialakításának eredményeként csökken a szegénység kultúrájának mértéke a leszakadó területeken élő hátrányos helyzetű emberek körében.

Ennek köszönhetően a közmunkaprogram munkaszocializációs célja valójában megvalósulhatna, viszont a periférikus területeken élő közfoglalkoztatottak szignifikáns többsége (a vidéki periférián: 77,2\%, a városi periférián: 100\%) nem keres munkát az 
elsődleges munkaerőpiacon ${ }^{97}$. A vidéki periférián élő inaktívak esetében ennek legfőbb oka, hogy jövőbeli megélhetésüket is a másodlagos munkaerő-piaci lehetőségekre alapozzák. Ezen eredmények tükrében nem meglepő, hogy a közmunkaprogram eredetileg megfogalmazott célját, vagyis, hogy a munkaszocializációt elősegítő tevékenységek hatására visszavezeti a résztvevőket az elsődleges munkaerőpiacra, nem érte el a periférikus területeken. Tehát a közmunkaprogram a kutatásom eredményei szerint is mérsékli az álláskeresési hajlandóságot, valamint igazolja azoknak a vizsgálatoknak (KolTAI 2014, CSERES-MOLNÁR 2014B, BAKÓ et al. 2014, BASS 2010) az eredményeit, amelyek szerint a közmunka csökkenti a nyílt munkaerőpiacon történő elhelyezkedés esélyeit. Emellett bebizonyosodott, hogy - a szakirodalmi tapasztalatokhoz hasonlóan (CSERES-MOLNÁR 2015, BASS 2010) - a közfoglalkoztatásban végzett feladatok egyszerüek ahhoz, hogy fejlesszék a dolgozók kompetenciáit, készségeit. Ez elsősorban a városi periférián élők esetében jelenik meg látványosan, ahol a munkakörök jellemzően - parkgondozás, városrendezés, takarítás betanított munkákhoz kapcsolódnak. Ezzel szemben a vidéki periférián a betanított- és segédmunkák munkák mellett adminisztratív és értékteremtő feladatok is végezhetőek. Következésképpen elmondható, hogy a közmunkaprogram nem készíti fel a dolgozókat a nyílt munkaerö-piaci követelményekre (VÁRADI 2010), ami tovább csökkenti a felfelé irányuló társadalmi mobilitás esélyét (TóTH et al. 2017).

A dolgozók mindkét területen a program pozitívumai között említették az adott munkatevékenységet és a kollegiális közösséget, valamint azt a tényt, hogy egyáltalán a közfoglalkoztatás megélhetési lehetőséget teremt számukra. Ennek ellenére egyes közfoglalkoztatottak kritikusan állnak a program hátterét megalapozó szociál- és foglalkoztatáspolitikai irányváltás aktív eszközök felé történő eltolódásához.

„Akkor is csinálni kell, ha nem akarod. Nehéz ez, férfimunka.” (27 éves tiszabői nő)

Esetükben érezhető a magyar munkaerőpiac rendszerváltást követő - szocialista felfogásról kapitalista szerkezetre történő - átrendeződésének hatása, és ezen változások olyan korábbi alternatív kezelési technikáinak befolyása, mint az inaktivitásba helyezés különböző lehetőségei: korai nyugdíjazás, ,rokkantosítás”, vagy a szociális transzferekre való hosszú távú berendezkedés. E körülmények még mindig hagytak megoldandó

97 Jóllehet, fizetési igényeik alapján jó esélyük lenne az elhelyezkedésre: a vidéki periférián élő aktív korúak átlagosan nettó 110.600 Ft-ért vállalnának munkát az elsődleges munkaerőpiacon, míg a városi periférikus területeken élők nettó $93.500 \mathrm{Ft}$-ot várnának jövedelemként a nyílt munkaerőpiacon. 
feladatot a periférikus területeken élő hátrányos helyzetűek munkaerő-piaci felzárkóztatásában. Hiszen a magyar szociálpolitika, a 2011-es szociális törvényben is megjelent jelentős irányváltása (MAGYAR KÖZLÖNY 2011, KoÓs 2016) óta az állam által nyújtott szociális támogatásra, vagyis aktív korúak ellátására - egyéb kondíciók mellett - csak az jogosult, aki a felülvizsgálatot megelőző egy évben legalább 30 napot dolgozott, amelyre a közmunkaprogram lehetőséget biztosít. A felajánlott (köz)munkát pedig el kell vállalni, amely az együttmüködés feltételét jelenti. A szociál- és foglalkoztatáspolitika ezen iránya elsősorban azt célozza, hogy az emberek ne szoruljanak bele abba a szegénységi csapdába ${ }^{98}$, amelybe a rendszerváltás után a munkaképes korú inaktívak tömegei estek bele. A magyar szociál- és foglalkoztatáspolitika irányváltása óta még csak alig néhány év telt el, amely időszak alatt az új elveken alapuló szociál- és foglalkoztatáspolitikai eszközökkel sem lehet teljesen pótolni a nyílt munkaerőpiacról való 20-25 év kiesés társadalmi következményeit. Hiszen a foglalkoztatásból való kikerülés következtében a munkamorál nagyon gyorsan devalválódik, és a korábban megszerzett szakmai kompetenciák, ismeretek és tudás a technikai fejlődés és a gazdasági átalakulás következtében hamar elértéktelenednek (SZÁSZVÁRI 2011). A szociál- és foglalkoztatáspolitikai irányváltás, és az ehhez kapcsolódó közmunkaprogram - amellett, hogy csökkenti az alkalmi munkavállalás lehetőségét és az elsődleges munkaerőpiacon történő elhelyezkedés szándékát ${ }^{99}$ - a nyílt munkaeröpiacról több évtizedre kikerült embereknek (is) biztosít lehetőséget a munkahelyi (re)szocializációhoz (SIPTÁR-TÉSITS 2014).

A periférikus területeken élők hátrányos helyzetének fennmaradásáért nem kizárólag a szocializmusban elindult társadalmi- és térbeli szegregálódási és marginalizációs folyamatok, valamint a szegénység kultúrájának szocializációs értékei és ezek átörökítése nevezhető meg felelősnek. A periférikus térségben élő emberek életkörülményeit olyan lokális szintü, külső tényezők is - önkormányzat, illetve környéken élő családok - konzerválják, amelyek anyagi érdeke a célcsoport - iskolai szint, pénzügyi körülmény és információs ellátottságbeli - helyzetének fenntartása. Ez egyben a függőségi viszonyt eredményező monopol helyzet megőrzésének alapját jelenti.

\footnotetext{
${ }^{98}$ A szegénységi csapda megjelenése azt a helyzetet jelzi, amikor a bruttó jövedelemnövekedés hatására összességében nettó jövedelemvesztés jön létre, vagy nem kapcsolódik hozzá jövedelemnövekedés (SEMJÉN 1996).

${ }^{99}$ A tiszabői közmunkások 77,2\%-a nem keres munkát a nyílt munkaerőpiacon.
} 
A jelenlegi müködési problémák és az esetleges, időszakos, nem tervszerü foglalkoztatás ellenére a közmunkaprogram nélkülözhetetlen a helyiek mindennapi életének fenntartásához, hiszen annak ellenére, hogy erősíti a paternalista jellegü rendszert, csökkenti a periférikus területen felgyülemlett szociális feszültségeket (VIRÁG 2009). Ezért a megkérdezett vidéki periférián élők elmondásai alapján tapasztalható függőségi viszonyok miatt kialakult - önkormányzati visszásságok ellenére ${ }^{100}$, a periférikus térségekben helyben elérhető munkahelyek hiánya miatt folyamatos igény van a programban való részvételre.

\subsection{Az eredmények gyakorlati jelentősége és hasznosíthatósága}

Magyarország szegénységi rátája a rendszerváltást követő munkanélküliség hatására jelentősen megemelkedett, amelynek kezelésére viszont az 1990-es évek elejének foglalkoztatás- és szociálpolitikai eszközei nem volt felkészülve. Az ennek hatására marginalizálódott társadalmi csoportokban kialakult szegénység kultúrája generációkon keresztül továbböröklődik. Ugyanakkor a hátrányos helyzetűek helyben maradása - a fentebb említett problémákon kívül - annak is köszönhető, hogy helyzetüket a szociális rendszerek és felzárkóztatási programok azóta sem kezelik komplexen: a közmunkaprogram „csak” a munkahely biztosításával foglalkozik, de nem tér ki azokra a körülményekre, amelyek a vidéki periférikus területek lakóinak, vagy szegénytelepeken élők helyzetét konzerválják. Azonban kizárólag olyan programok lehetnek tartósan sikeresek, amelyek hosszú távon, több oldalról megközelítve, összetetten állnak a problémához: a munkaerő-piaci nehézségek mellett figyelnek a periférikus területen élők egyéni életvezetésére, közösségi szemléletére, szociális helyzetére és a gyermekek napközbeni elhelyezéséhez kapcsolódó feladatokat is képesek megoldani. Emellett a szocializációból adódó nehézségekre, a lakáshelyzetre és az egészségi állapotra is figyelmet fordítanak. A programokat azért is szükséges megszakítás nélkül, hosszú távra tervezni, mert a periférikus területeken élő hátrányos helyzetü emberek bizalmát csak igen nehezen lehet megnyerni, és két részprogram közötti időszak alatt bizalomvesztés következik be, amely jelentősen csökkenti a sikerességet és az eredményesség esélyét. Tehát a hátrányos helyzetű csoportokkal való foglalkozás - képzési szinten is - mindenképpen komplex szemléletet, több szemszögből való megközelítést igényel. A hosszú távú megközelítésben célszerü a

100 Fontos megjegyezni, hogy a szolnoki közfoglalkoztatási programban nem találtam hasonló visszaéléseket. 
foglalkozások során tekintettel lenni, hogy - a Maslow-féle piramis (MASLOW 1943) alapján - a résztvevők számára elsőként az alapvető fiziológiai szükségleteik kielégítését kell biztosítani, majd a biztonságot megteremteni. Tehát az étkezésük mellett megélhetési támogatást biztosítani számukra, amely egyben optimális motivációs eszközöket is jelentenek. Enélkül nem tudnak részt venni a képzéseken, ugyanis e feltételeket a mindennapi megélhetés érdekében maguk és családjuk számára elő kell teremteni. Eredményt pedig csak fokozatos és következetes folyamattal lehet elérni az alapkompetenciáktól (VELKEY 2014C) indulva az államilag elismert szakképesítést nyújtó tanfolyamokon keresztül az elsődleges munkaerőpiacon való elhelyezkedésig.

Az eredmények alapján elmondható, hogy a periférikus területeken a hátrányos helyzetben élők körében van igény a munkavégzésre, és - a munkaerő-hiány miatt - a foglalkoztatók részéről is lenne fogadókészség az alkalmazásukra. Ellenben az alacsony iskolázottság miatt a hátrányos helyzetűek többségének munkavégzéshez szükséges képességei megfelelő képzések nélkül nem alkalmasak az elsődleges munkaerőpiacon található munkahelyek által elvárt, erősen teljesítményorientált követelményeknek megfelelő munkavégzésre. Ezért kulcsfontosságú a periférikus területeken élők foglalkoztathatósági helyzetének javítása, amely során - az iskolai végzettség és korábbi munkatapasztalat alapján kialakított - alkalmazott fejlesztő képzések elengedhetetlenek. Viszont amennyiben sikerül felkelteni a motivációjukat, a továbblépés igénye is kialakul bennük (SZVF 2017). Megoldás lehet a szakaszos betanítás, amelynek folyamán az első, betanító ütemben alacsonyabb fizetés mellett az elvárthoz képest csökkentett normatív teljesítmény van meghatározva, a bejárásban pedig vállalati buszjárat segítené a periférikus területeken élőket. Emellett minden befogadó munkahely esetében javasolt egy üzemi szociális munkás (KISS et al. 2013) alkalmazása, aki segíti a hátrányos helyzetü emberek beilleszkedését, munkahelyi szocializációját. Ugyanakkor még ilyen feltételek mellett is csak hosszú távon várható eredmény, hiszen a munkaerö-piaci szemléletváltáshoz szükséges idő akár generációs időszakokban is mérhető. A munkaerőpiacra való bekerülés támogatására pedig a vidéki periférikus területeket övező és a városokban található ipari parkokkal vagy nagyobb vállalatokkal való közös, képviseleten keresztül történő kommunikáció és megoldáskeresés lehet megfelelő eszköz. Az elsődleges munkaerőpiacra történő belépés egyik fő akadálya az, hogy a felvételhez szükséges kompetencia-teszt kitöltése sokuk számára nehézséget jelent. Ezért javasolt kifejezetten a kulcskompetenciák átadására épülő felzárkóztató képzéseket indítani azok számára, akik szeretnének a nyílt munkaerőpiacon elhelyezkedni. A képzések megtervezésekor figyelembe kell venni, hogy a hátrányos 
helyzetủ célcsoport koncentrációs képessége és időgazdálkodási készsége igen alacsony szintű (SZVF 2017), ezért fontos, hogy ez a dolgozók számára gyors eredményekkel, megtérüléssel, vagy produktummal járjon. Ez a megtérülés lehet egy képzési egységhez kapcsolódó elismerés, egy magasabb szintű tréningbe való kapcsolódós lehetősége, vagy éppen egy konkrét pozíció, ahol a munkaadó a program legelejétől bekapcsolódik az együttműködésbe (TÉSITS et al. 2018) és az esetleges problémák megoldásába is. Kiemelten fontos, hogy lássanak lehetőséget a folytonosságra, ezért alapvető szempont, hogy az egymásra épülő modulok között a lehető legkevesebb idő teljen el, mert - a szegénység kultúrájára jellemző rövid távra tervezés miatt - ha a befektetett munkájuk nem hasznosul azonnal, az esetükben csalódást és reményvesztést eredményez.

Tehát a megoldás mind hosszú, mind pedig rövid távon az oktatásban rejlik, igaz az eltérő tervezési idő különböző képzési módszereket is jelent. Míg rövid távon az aluliskolázott emberek alapvető kompetenciák elsajátítására irányuló (írás, olvasás, számolás) és a betanított munkára való felkészítő tréningjei vezethetnek részeredményekhez, hosszú távon már a következő generációkra kell gondolni. Az oktatás, mint az elsőszámú megoldás természetesen igen összetett: a leghátrányosabb helyzetü családok gyermekeitől - az eltérő szocializáció és az eszközökhöz való hozzáférés hiánya miatt - az általános iskola első éveiben nem lehet ugyanazt a teljesítményt elvárni (AMBRUS 2002), mint a középosztályból érkező iskolatársaiktól.

„Az alapvetö probléma az oktatásban van, ott kéne őket indítani az alapvetö neveléssel... de nem erre szocializálódtak. A gyerekek is azt látják, hogy az anyjuk is elvan, körülötte mindenki elvan, jobb az úgy, mint beülni az iskolapadba... A gyerekek meg mennek iskolába, ahogy tudnak, amikor pedig mennek haza, nem tudják, hogy mi fogadja öket: az anyjuk éppen elment otthonról, mert valahogyan pénzt kell szerezniük, hiszen a (bank)kártyájukat elvették, a kamatozás pedig nyilvánvaló a kábítószer, vagy bármi más miatt.” (Családsegítő központ munkatársa)

A periférikus területeken élő diákok iskolai integrációjára és iskolai teljesítményére a szülők alacsony iskolázottsága, munkaerőpiactól való távolléte és a nem megfelelő otthoni lakáskörülmények mind jelentős hatással vannak (KENDE 2000, FORRAYHEGEDÜS 1991, HORVÁTH 2015). A periférián élő hátrányos helyzetű gyerekek családi környezetben elsajátított értékrendje teljesen eltér azoktól, amiket - középosztály értékeire építve - az iskola előnyben részesít (AMBRUS 2002). A családi neveltetés, a szociokulturális háttér (VELKEY 2011) viszont erős összefüggést mutat az iskolai 
teljesítménnyel (MOLLENHAUER 1974), hiszen a szülők társadalmi hátrányai a gyerekekre átörökítődnek, amelyek az iskolai tanulmányok során felerősödnek (FERGE 2000). Így a jelenlegi rendszer újratermeli és hosszú távra konzerválja a fennálló társadalmi viszonyokat (BOURDIEU 1978). A periférikus területeken élő hátrányos helyzetü tanulók az iskolában olyan feladatokkal, szabályokkal, eszközökkel és - ami ennél is fontosabb - nyelvvel és nyelvezettel találkoznak (FIÁTH 2000, BABUSIK 2000, DERDÁK-VARGA 1996), amelyeket korábban családi, vagy közösségi környezetben nem volt lehetőségük megismerni, ezért nincsenek is felkészülve ezek befogadására. Sajnos, a magyar tanárképzés sincs módszertani szempontból kellően felkészülve és megfelelő eszközökkel ellátva a hátrányos helyzetü gyerekek tanítására. Így ezek a gyerekek folyamatos kudarcélményt szereznek (VELKEY 2013), ennek hatására pedig az iskola egy „nem kedvelt” hellyé változik, amelyet többnyire az otthoni, családi környezetben - a korábbi közoktatási kudarcok tapasztalataira alapozva - meg is erősítenek (FIÁTH 2000, SZVF 2017). Ezért az oktatási módszerek fejlesztését már a tanárképzésnél javasolt elkezdeni, méghozzá olyan szempontok alapján, hogy a kidolgozott stratégiák és technikák képesek legyenek megfelelően felkészíteni az általános iskolai tanárokat egy olyan gyermekek fogadására és tanítására, akik a többségi társadalomtól egészen eltérő normák, értékek és nyelvezet között, vagyis a szegénység kultúrájának szabályai és értékei alapján szocializálódtak.

A periférikus területek és a telepi körülmények, valamint a többségi társadalomtól eltérő szociokulturális háttér miatt kialakult jelentős lemaradást eleinte korai fejlesztés ${ }^{101}$ segítségével elért kiegyenlítő hatással rendelkező bölcsődei, majd óvodai ellátással (CSAPÓ et al. 2006, PIK 2001), később pedig integrált oktatással lehet csökkenteni, ezzel javítva az iskolai teljesítményt (SZMJVÖ 2014A). Ehhez nélkülözhetetlen a ,,white flight” (RADÓ 1997, TREMLETT 2005) jelenség - Tiszabőn (DERDÁK-VARGA 1996) és Szolnokon is érezhető eredményének - visszaszorítása, mivel a tehetősebb, általában a többségi társadalomhoz tartozó családok gyermekeiket a periférikus területen található iskolából egy olyan - többnyire centrumban elhelyezkedő - oktatási intézménybe íratják, ahol kevesebb hátrányos helyzetü diák tanul. E jelenség a szolnoki Szent Tamás Görögkatolikus Általános Iskola és Óvoda esetében úgy mutatkozik meg, hogy a környéken élők családok éppen azért nem választják az iskolát gyermekeiknek, mert a Törteli úti telepen élö gyerekek is odajárnak (SZVF 2017). A hátrányos helyzetü gyerekek oktatásában kiemelt fontosságú a barátságos,

101 A korai fejlesztés a 6 év alatti gyerekek kezdeti hátrányainak ledolgozását gyógypedagógiai módszerekkel segítő foglalkozás (KEREKI-SZVATKÓ 2015). 
személyközpontú légkör (FIÁTH 2000), amelyre a Waldorf-módszer különösen alkalmas lehet. Ez az oktatási technika segíti őket a többségi társadalomtól eltérő „másság” érzéséből adódó szorongás leküzdésében (SÁGHY 1995). Emellett egyes kutatók az osztályszerkezet helyett kisebb - érdeklődési kör és tudásszint alapján kialakított csoportok szerinti müködést (FORRAY-HEGEDÜS 1991), illetve multikulturális nevelést javasolnak, amely egy olyan ösztönző környezetben (LANDAU 1997) segíti az etnikai és nemzeti kisebbségeket értékeik és azonosságtudatuk megőrzésében, ahol a diákok kis létszámú osztályokban - a családtagok bevonásával - kaphatnak ismereteket egymás kultúrájáról. Az oktatás ezen szemlélete a kisebbségeben az önbecsülés és az önismeret mellett az elfogadottság érzését erősíti, a többségi társadalom tagjaiban pedig fokozza a kisebbségek elfogadásának érzését, amely segít felszámolni a „,mi-ők” szemléletet az iskolákban és a társadalomban (FIÁTH 2000, SzÖKE 1998, CSEPELI-NEMÉNYI 1999). Emellett képes biztosítani a periférikus területeken élő társadalmi csoportok munkaerőpiaci megjelenéséhez szükséges alapkészségeket, amely elösegítheti a társadalmi

\section{különbségek csökkenését.}

Hasonló célok megvalósítására alkalmas módszert dolgozott ki a Magyar Máltai Szeretetszolgálat (KISS et al. 2013), amely a periférikus területeken élő hátrányos helyzetűek társadalmi- és munkaerő-piaci integrációját támogatja. A Jelenlét Program éppen azokat a mélyszegénységben élő kirekesztett közösségeket, szegregátumokban élöket helyezi a középpontba, akik a kutatásom célcsoportjai voltak. A program felzárkóztatásra irányuló fejlesztéseinek keretét azok a hasonló problémák megoldására való törekvés jelenti, amelyek a periférikus területen élők többségének leküzdhetetlen nehézséget jelentenek. A Jelenlét Program tekintettel van a periférikus területeken élő társadalmi csoportok életét hátráltató előítéletek, a szolgáltatások elérésének korlátozottsága, a közlekedési nehézségek, valamint az iskolai hátrányok következtében fellépő gyerekkori fejlesztések elmaradása miatt kialakuló iskolai kudarcokra, lemorzsolódásra és alacsony iskolai végzettség egyenes következményeként fellépő a munkanélküliségre (VÁMOSI 2005). A program figyelembe veszi a hátrányos helyzetü emberek - jellemzően elégtelen étkezés, lakhatási viszonyok, vagy éppen szenvedélybetegség által kialakult - egészségi állapotát és az olyan általános problémákat, mint a megélhetési bünözés, uzsorakamatra történő kölcsönzés, az emberkereskedelem és a prostitúció (PÁSZTOR-PÉNZES 2018). A Máltai Szeretetszolgálat Jelenlét Programjának célja, hogy az adott területen egy olyan közösséget hozzon létre, amely a fejlesztések eredményeként önállóan is képes megoldani problémáit. A Jelenlét Program a helyi szükségleteknek megfelelő komplex szemléletet alkalmaz, amely 
közösségfejlesztés, a bizalomépítés és a szociális munka eszköztára mellett egészségügyi, oktatási, gyermekvédelmi, lakhatási és foglalkoztatási fejlesztő elemeket is használ. Ennek következtében a program azokkal a kompetenciákkal ruházza fel az adott területen élőket, amely megteremti a lehetőséget a többségi társadalommal való kapcsolat kialakítására.

\subsection{A periférikus területek várható jövője}

A vidéki periférikus területeket mintázó Tiszabő jövője hosszú távon pozitív reményeket kelthet, hiszen a kormány 1391/2016. (VII. 21.) határozata (MAGYAR KÖZLÖNY 2016) alapján kiemelt program keretében foglalkozik a falu helyzetével, amelyben a Máltai Szeretetszolgálat hangsúlyos szerepet kapott. A szervezet jelenléte mára látványos eredményeket hozott: megújult az iskolaépület (Melléklet 4., 8. és 9. kép), az oktatási szemléletmódváltás pedig a szakemberek által alkalmazott innovatív módszerekben és az iskolán kívüli programokban is érzékelhető (HORVÁTH 2018). Emellett a magyar munkaerőpiac paradoxona, vagyis a munkahelyek hiánya mellett párhuzamosan megjelenő munkaerőhiány fokozódása is pozitív irányú változást feltételez a település életében. E munkaerö-piaci körülmények között a vállalatok egyre inkább csökkentik a szakmai kompetenciák szükségességét és növelik a foglalkoztatási területet. A szolnoki bőrgyár által müködtetett dolgozói buszok jelenleg még nem mennek be Tiszabőre; a faluhoz legközelebb csak Kunhegyesen és Fegyverneken állnak meg.

„A falu le van járatva, nem jön be a gyár busza.” (41 éves tiszaböi nö)

A munkaerőhiány miatt viszont a kecskeméti Mercedes és a győri Audi toborzása is már a közeli Törökszentmiklósig terjed. A közeljövőben pedig várhatóan minden környékbeli gyárnak tovább kell növelnie foglalkoztatási területét, vagyis munkaerő vonzáskörzetét, amelynek köszönhetően a tiszabőiek számára egyre több munkalehetőség jelentkezik.

A területi stigma fennmaradása mellett a falu esélyeit némileg csökkenti, hogy míg a jelenleg az elsődleges munkaerőpiacon dolgozók átlagosan két gyermeket vállalva csak reprodukálják önmagukat, addig az aktív korú inaktívak az átlagosan négy utóddal megkétszerezik azon gyermekek számát, akik olyan családi környezetben szocializálódnak, ahol a szülők nem dolgoznak az elsődleges munkaerőpiacon. E helyzet megoldódására jelenthet reményt a szociál- és foglalkoztatáspolitika aktív eszközökkel 
való operálás felé történő, 2011-ben kezdődött irányváltása (KoÓs 2016), amennyiben a döntés meghozza azt a várt eredményt, hogy a közmunkaprogram segít kiemelni a szegénységi csapdába (SEMJÉN 1996, AZAIRADIS-STACHURSKI 2005) szorult, a többségi társadalom normáitól elszakadt embereket (SIPTÁR-TÉSITS 2014, TÓTH et al. 2017). Ehhez szükséges, hogy a közfoglalkoztatás egyrészt az elsődleges munkaerő-piaci igényekre épüljön, ahol a dolgozók a nyílt munkaerőpiacon szereplő vállalatoknál elhelyezkedve valós, értékteremtő tapasztalatot szerezhetnek (SIPTÁR-TÉSITS 2014). Ennek eredményeként a közmunkaprogram egy, a jelenleginél magasabb presztízst kivívva, a skandináv közmunkaprogram-modell irányába mutató átalakításával (BAKÓ 2015), a munkáltatók számára nyújtott kedvezményekkel együtt bizalmat ébresszen az elsődleges munkaerő-piaci szereplőkbe, akik így bátrabban nyúlhatnak a közfoglalkoztatottak alkalmazásához. Ez pedig (tovább)növelheti a periférikus területeken élő hátrányos helyzetüek nyílt munkaerő-piaci szerepvállalását. Ennek viszont elsődleges feltétele a területi stigma szerepének halványulása.

A centrumhoz közeli periférikus térségek mintaterületeként szolgáló szolnoki Törteli úti szegregátum jövője is közvetetten, de kifejezetten pozitív irányt vehet, amennyiben Magyarország képes lesz megvalósítani az Európa 2020 stratégiában vállalt célkitüzéseket. A dokumentum öt kiemelt területen megfogalmazott céljai erősen összefüggenek egymással (BRUDER et al. 2011). Ezek közül három közvetlenül kapcsolódik az olyan leszakadó társadalmi csoportok felzárkóztatásához (KERESZTES 2016), mint a telepen élő hátrányos helyzetü közösségek. A stratégia különösen a hátrányos helyzetü csoportok körében szeretné elérni, hogy a 20 és 64 év közöttiek foglalkoztatottsága elérje a 75\%-ot (EuRÓPAI BIZOTTSÁG 2010). E tekintetben Magyarország 2011 és 2016 között közel 5\%-kal tudta növelni a foglalkoztatottak arányát, amellyel már csak 1,2\%-kal marad el az EU átlagától (KERESZTES 2016). Viszont érdemes figyelembe venni, hogy a hazai foglalkoztatotti statisztikák a másodlagos munkaerőpiacon jelenlévő közfoglalkoztatottakat is ide számítják (SCHARLE 2016). Az Európa 2020 célja, hogy az iskolai lemorzsolódási arányt $10 \%$ alá csökkentse (EuRÓPA BizOTTSÁG 2010), amely kiemelten fontos lenne a telepen élők számára. Mivel a szakmai tanfolyamok jelentős része is megköveteli az alapfokú képesítést, az alacsony iskolai végzettség hozzájárul a munkalehetőségek hiányához. A célok elérésének tekintetében a kutatás időpontjában Magyarország mutatója 23,9\% volt (KERESZTES 2016). Az iskolázottsági szint emelkedése és a foglalkoztatottság közötti pozitív kapcsolatot az EUROSTAT (2016) adatai is jelzik, emellett ezek a faktorok a szegénységet is csökkentik, amely összefüggéseket jelen kutatás eredményei is 
alátámasztják.

Amennyiben az Európa 2020 stratégia célkitűzései megvalósulnak, a szolnoki telepen élők munkaerő-piaci esélyei és anyagi jólétük lehetőségei is jelentősen javulnak. Így az Európa 2020 harmadik kapcsolódó célja is könnyebben teljesülhet, amely legalább 20 millió fővel igyekszik csökkenteni a nyomorban és társadalmi kirekesztettségben élők számát az EU-ban (EURÓPAI BIZOTTSÁG 2010). Ezeket a célokat próbálja támogatni a 2018-ban kezdődött, jelenleg is a Törteli úti szegregátumban müködő, EU által támogatott projekt, amely a Széchenyi 2020 program keretében valósul meg (VG.HU 2018). A fejlesztés infrastrukturális része a lakások bővítését és a terület korszerüsítését célozza, emellett a Törteli út lakóinak társadalmi fejlődését közösségfejlesztő tevékenységekkel, szociális munkával, egészségmegőrző programokkal, valamint felzárkóztató képzésekkel segíti elő. A projekt célja - a korábbi programok eredményeire építve - megállítani a telepen élők jelenlegi körülményeinek, valamint társadalmi- és munkaerö-piaci hátrányainak újratermelődését. A fejlesztés azért is reményt keltő, mert a programelemek között szerepel az alapfokú végzettség megszerzésének lehetősége, és alkalom nyílik helyi munkaerő-piaci szempontból releváns, valós munkaerő-piaci igényekre épülő szakmák - személy- és vagyonőr OKJ és textiltermék-összeállító OKJ - képzésein való részvételre (SZVF 2017). Amennyiben a telep lakóinak képzettségi szintje ezeknek a programok hatására emelkedik, a helyben található munkahelyek is elérhetővé válnak számukra. Mindemellett a textiltermékösszeállító képzést sikeresen elvégzett embereknek konkrét, elsődleges munkaerő-piaci foglalkoztató is munkát ajánlott (SZVF 2017). Eszerint, ha a program tartja komplex szemléletét, akkor a jövőben a telepen élő családok körében csökkenhet az alkalmi munkavállalás aránya, ezzel párhuzamosan pedig növekedhet az elsődleges munkaerő-piaci integráció mértéke. Ezt a folyamatot támogatja a magyarországi munkaerőhiány is, amely egyes pozíciókban csökkenti szakmai tudással kapcsolatos elvárások szintjét. Ennek eredményeként pedig emelkedhet a szolnoki szegregátumban élők elsődleges munkaerő-piaci szerepvállalása. Azonban ennek alapvető feltétele a területi stigma szerepének redukálódása, amelyre az említett EU által finanszírozott program is megoldást nyújthat, amennyiben eredményesen megvalósul azon kiemelt programelem, amely a szegregátumot magába foglaló városrészben élők, illetve Szolnok lakossága mellett a helyi munkáltatókat is próbálja érzékenyíteni a telepen élők problémái iránt, ezzel csökkentve a Törteli úti szegregátum területi megbélyegzését. 


\section{Felhasznált irodalom}

ÁBRAHÁM Á.-KERTESI G. (1996): A munkanélküliség regionális egyenlőtlenségei Magyarországon 1990 és 1995 között. A foglalkoztatási diszkrimináció és az emberi tőke változatos szerepe. In: Közgazdasági Szemle, 43:(7-8.) pp. 653-681.

AlPEK B. L. - TÉSITS R. - BOKOR L. (2016): Group-specific Analysis of Commuting in the Most Disadvantaged Areas of Hungary. In: Regional Statistics, 6:(1) pp. 54-81.

AlpeK B. L. - TÉSITS R. - HovÁNYI G. (2018): Spatial Inequalities of Disadvantage Accumulation and their Impact on Employability in Hungary. In: Regional Statistics, 8:(1.) pp. 135-152.

AlPEK B. L. - TÉSITS R. (2014A): A munkaerőpiaci szenzitivitás. Új módszer a magyarországi munkaerőpiac területi, térszerkezeti kérdéseinek feltárásában. In: Területi Statisztika, 54:(4) pp. 333-359.

ALPEK B. L. - TÉSITS R. (2014B): Egy többváltozós modell definiálása az álláskeresők mobilitási fokának vizsgálatához. In: Szakképzési Szemle, 30:(2.) pp. 4-21.

ALPEK B. L. - TÉSITS R. (2017A): A foglalkoztathatóság fogalmi kerete és dimenziói Magyarországon. In: Gazdaság és Társadalom, 9:(2) pp. 99-122.

ALPEK B. L. - TÉSITS R. (2017A): A munkaerőpiaci esélyhátrányok halmozódása és területi jellegzetességei Magyarországon. In: Ács K. - BóDOG F. - MECHLER M. MÉszÁros O. - PóNUSZ R. (szerk.): VI. Interdiszciplináris Doktorandusz Konferencia 2017. Tanulmánykötet, Pécsi Tudományegyetem Doktorandusz Önkormányzat, pp. 20-39.

ALPEK B. L. - TÉSITS R. (2017B): Measuring Regional Differences in Labour Market Sensitivity in Hungary. In: Applied Spatial Analysis and Policy, 11:(4) pp. 721736.

Ambrus P. (1994): A szegénykultúra. In: AMBrus P. - CSÉPE P. - ForRAI J. (szerk.): Egészségügy, kommunikáció, cigányság. Budapest, Új-Aranyhíd

Ambrus P. (2002): Szegénykultúra. In: Ambrus P. - CSÉPe P. - Forrai J. (szerk.): Egészségügy, kommunikáció, cigányság. Budapest, Új-Aranyhíd

ANDORKA R. (2006): Bevezetés a szociológiába. Budapest, Osiris Kiadó

ARACSI L. - PÁL V. (2004): A többoldalúan hátrányos társadalmi csoportok egészségi állapotának földrajzi jellemzői. In: BARTON G. - DORMÁNY G. (szerk.): A magyar földrajz kurrens eredményei: II. Magyar Földrajzi Konferencia. Szeged, SZTE TTIK Természeti Földrajzi és Geoinformatikai Tanszék, pp. 50-65. 
Azairadis, C. - Stachurski, J. (2004): Poverty traps. In: Aghion, P. - Durlauf, S. (eds): Handbook of Economic Growth. Amsterdam, North-Holland, pp. 295-384.

BABBIE, E. (2003): A társadalomtudományi kutatás gyakorlata. Budapest, Balassi Kiadó Babinska, I. - Gecková A. M. - Pella, D. - Stefková, G. - Jarcuska, P. -Veselska Z. D. (2014): Does the population living in Roma settlements differ in physical activity, smoking and alcohol consumption from the majority population in Slovakia? In: Central European Journal of Public Health, May 2014

BABUSIK F. (2000): Az iskolai hatékonyság kulcstényezői a romák oktatásában. Budapest, Delphoi Consulting

BABUSIK F. (2007): Magyarországi cigányság - Struktruális csapda és kirekesztés. In: Esély, 2007:(1.) pp. 3-23.

BACSIK M. (2013): Vissza a munka világába: A közfoglalkoztatás útján Jász-NagykunSzolnok megyében. In: Economica, 5(Klnsz. 1), pp. 96-104.

BAJMÓCY P. - BALOGH A. (2002B): Aprófalvas településállományunk differenciálódási folyamatai. In: Földrajzi Értesítö (1952-2008), 51:(3-4.) pp. 385-405.

BAJMÓCY P. - BALOGH A.(2002A): Néhány társadalmi-gazdasági mutató településméret szerinti differenciáltsága Magyarországon. In: FARKAS GY. - ZÁBRÁDI Zs. (szerk.): Földrajzos Doktoranduszok VII. Országos Konferenciája. Budapest, ELTE TTK Földrajzi Tanszékcsoport, Paper 3.

BAJMÓCY P. - BOROS L. (2005): Az aprófalvak népesedése 1949-től napjainkig. In: CSAPÓ T. - KoCsIS Zs. - LENNER T. (szerk.): A településföldrajz helyzete és főbb kutatási irányai az ezredforduló után. Szombathely, I. Településföldrajzi Konferencia. pp. 61-79.

BAJMÓCY P. - ILCSIKNÉ MAKRA Zs. - TÓTH L. (2018): A hazai külterületek átalakulása 1990 után. In: Településföldrajzi Tanulmányok, 7:(1) pp. 3-17.

BAJMÓCY P. - ILCSIKNÉ MAKRA Zs. (2018): Periféria, határmentiség, etnicitás. A Zselic és a Lippai-dombság községeinek népességföldrajzi folyamatai 1910-2011 között. In: PÉNZES J. (szerk.): Falu - város - periféria: határon innen és túl: Süli-Zakar István professzor emlékére. Debrecen, Didakt Kiadó, pp. 89-99.

BAJMÓCY P. - JózSA K. - PÓCSI G. (2007): Szélsőséges aprófalvak. Aprófalvak a településlisták végein néhány társadalmi gazdasági mutató alapján. In: CSAPÓ T. Kocsis Zs. (szerk.): A kistelepülések helyzete és településföldrajza Magyarországon: III. Településföldrajzi konferencia. Szombathely, Savaria University Press, pp. 83-101. 
BAJMÓCY P. - MAKRA Zs. (2015): Aprófalvak kihalása és/vagy megmaradása Magyarországon. In: RAKONCZAI J. - BLANKA V. - LADÁNYI Zs. (szerk.): Tovább egy zöldebb úton: A Szegedi Tudományegyetem Földrajzi és Földtani Tanszékcsoport részvétele a ZENFE programban (2013-2015). Szeged, SZTE TTIK Földrajzi és Földtani Tanszékcsoport, pp. 126-134.

Bakó T. - Cseres-Gergely Zs. - KÁlmán J. - MolnÁr Gy. - Szabó T. (2014): A munkaerőpiac peremén lévők és a költségvetés. Budapest, MTA KRTK KTI

BAKÓ T. - MOLNÁR GY. (2016): A közfoglalkoztatás hatása a munkapiaci helyzetre. In: MTA KRTK KTI - A 2015-2016. évi munkaerőpiaci helyzet és a folyamatok várható alakulása, hatása a növekedésre és az államháztartásra, Költségvetési Tanács számára készített tanulmány, pp. 57-114.

BAKÓ T. (2015): Skandináv közmunkaprogramok. In: FAZEKAS K. - VARGA J. (szerk.): Munkaeröpiaci Tükör, 2014. Budapest, MTA Közgazdaság- és Regionális Tudományi Kutatóközpont Közgazdaság-tudományi Intézet, pp. 63-65.

BALCSÓK I. (2000): Hátrányos helyzetű társadalmi rétegek az Északkelet-Alföld határ menti térségeinek munkaerőpiacán. In: Tér és Társadalom, 14:(2-3), pp. 285-294.

BÁNFALVI GY. (2016): A szegénység etnicizálódása a biharkeresztesi mikrotérségben. In: Metszetek, 5:(2.) pp. 81-92.

BARANyi B.-G. FeKETE É. - KonCZ G. (2003): A roma-szegregáció kutatásának területi szempontjai a halmozottan hátrányos helyzetủ encsi és a sellyei-siklósi kistérségekben. In: Kisebbségkutatás, 12:(2) pp. 344-363.

BARANYI B. (1993): A „periféria perifériáján”- A határmentiség kérdőjelei egy vizsgálat tükrében az Északkelet-Alföldön. In: Tér és Társadalom, 13:(4), pp. 17-44.

BARANYI B. (2004): Gondolatok a perifériaképződés történeti előzményeiről és következményeiröl. In: Tér és társadalom, 18:(2), pp. 1-21.

Bass L. - Darvas Á. - Dögei I. - Ferge Zs. - JuhÁsz G. - MÁRton I. - MÁrton K. TAUSZ K. (2002): Exit from and non-take up of public services. A comparative analysis: France, Greece, Spain, Germany, Netherlands, Hungary. Exnota Thematic Network - Hungarian Final Report. Project director: P. Warin

BASS L. (2010): Az „Út a munkához” program hatása - egy kérdőíves felmérés tapasztalatai. In: Esély, 2010:(1) pp. 46-64.

BECSEI J. (2006): A magyarországi népesség iskolázottságának területi viszonyai. In: KISS A. - MeZÖSI G. -SÜMEGHY Z. (szerk.): Táj, környezet és társadalom. Ünnepi tanulmányok Keveiné Bárány Ilona professzor asszony tiszteletére. Szeged, SZTE 
Éghajlattani és Tájföldrajzi Tanszék; SZTE Természeti Földrajzi és Geoinformatikai Tanszék, pp. 99-107.

BÉKI O. (2013): A serdülőkori gyermekvállalás lehetséges okai egy cigánytelepen. In:

Belvedere Meridionale. 23:(3), pp. 117-129

BÉNYI M. - KÖSZEGI E. (2003): Cigánytelepek Magyarországon. In: Család, gyermek, ifjúság, 15:(2), pp. 18-24.

Berndt, M., Colini, L. (2013): Exclusion, marginalization and peripheralization.

Leibniz Institute for Regional Development and Structural Planning. Berlin, Working Paper; 49.

BM - BELÜGYMINISZTÉRIUM (2015): Beszámoló a 2014. évi közfoglalkoztatásról.

Belügyminisztérium, Közfoglalkoztatási és Vízügyi Helyettes Államtitkárság, Budapest

BM - BELÜGYMINISZTÉRIUM (2016): Tájékoztató a közfoglalkoztatáshoz kapcsolódó legfontosabb bérek változásairól 2011-2017. Közfoglalkoztatási és Vízügyi Helyettes Államtitkárság, Budapest, 2016. 12. 20.

Boros L. - NAGY GY. (2013): A 2010-es árvizek hatásai és a környezeti igazságosság problematikája Borsod-Abaúj-Zemplén megyében. In: A Falu, 28, pp. 43-54.

Boros L. - PÁL V. (2011): A gazdasági válság hatásai és a rá adott válaszok különböző földrajzi léptékeken. In: Földrajzi Közlemények, 135:(1.) pp. 17-32.

Boros L. (2010): A földrajzi alapkategóriák gazdaságföldrajzi kontextusban. In: MÉSzÁRos R. (szerk.): A globális gazdaság földrajzi dimenziói. Budapest, Akadémiai Kiadó, pp. 40-56.

BouRDIEU, P. (1978): A társadalmi folyamatok újratermelődése. Budapest, Gondolat Kiadó

BOURDIEU, P. (1998): Gazdasági tőke, kulturális tőke, társadalmi tőke. In.: LENGYEL GY.

- SzÁNTÓ Z. (szerk.): Tőkefajták: A társadalmi és kulturális erőforrások szociológiája. Budapest, Aula Kiadó

Bradbury, B. - JANTTI, M. (1999): Child Poverty across Industrialized Nations. In: Innocenti Occasional Papers, Economic and Social Policy Series, no. 71. Florence, UNICEF International Child Development Centre

Brooks-Gunn, J. - Duncan, J. G. (1997): The Effects of Poverty on Children. In: The Future of Children, 7:(2) pp. 55-71.

Bruder E. - Meulders, D. - OBÁdovics Cs. (2011): Who Are the Working Poor in the Visegrad Countries? In: VillánYI L. - KÁPOSZTA J. - NAGY H. (szerk.): Development Prospects of Rural Areas. Lagging behind in the CEE regions. 
Conference Proceedings. Szent István University. Gödöllő, Faculty of Economics and Social Sciences, pp. 202-211.

BUJDOSÓ Z. 2004: Munkaerővándorlás Hajdú-Bihar megye határa menten. In: SÜLIZAKAR I. (szerk.): Határon átnyúló kapcsolatok, humán erőforrások - Kossuth Egyetemi Kiadó, Debrecen, pp. 301-307.

CASTEL, R. (1993): A nélkülözéstől a kivetettségig - a „kiilleszkedés” pokoljárása. In: Esély, 1993:(3.) pp. 3-23.

CEGLÉDY T. (2014): Európa - A centrum-periféria kapcsolat kereskedelmi kérdései. In: Gazdaság és Társadalom, 6:(3). pp. 3-24.

Cloward A. Richard - LlOYd E., OHLIN (1960): Deliquency and Opportunity. New York, Free Press

CZIBERE I. (2012): Nők mélyszegénységben. Személyes életvilágok és cselekvési perspektívák a mélyszegénységben élő nők mindennapjaiban. Budapest, L'Harmattan

CSAPÓ B. - FAZEKAS K. - KeRTESI G. - KÖLlŐ J. - VARGA J. (2006): A foglalkoztatás növelése nem lehetséges a közoktatás átfogó megújítása nélkül. In: Élet és Irodalom, 50:(46.)

CSATÁRI B. (2001): Az európai vidékiség és az Alföld. In: Alföldi tanulmányok, 2000/2001:(18.) pp. 44-62.

CSATÁRI B. (2018): Rendszerváltoztatás Kelet-Közép-Európa vidékein és egy alföldi faluban, többféle nézőpontból. In: PÉNZES J. (szerk.): Falu - város - periféria: határon innen és túl: Süli-Zakar István professzor emlékére. Debrecen: Didakt Kiadó, pp. 261-275.

CsÉPE P. (2010): Hátrányos helyzetű csoportok egészségfelmérése és egészségfejlesztése különös tekintettel a roma populációra. Budapest, SOTE

CSEPEli Gy. - NEMÉNYI M. (1999): A toleranciára nevelés esélyei. In. Educatio, 1999:(nyár)

CSERES-GERGEly Zs. - MolnÁr GY. (2014A): A közfoglalkoztatás a munkaügyi rendszerben, 2011-2013 - Alapvető tények. In: FAZEKAS, K. - VARGA, J. (szerk.): Munkaerőpiaci Tükör 2014. Budapest, MTA Közgazdaság- és Regionális Tudományi Kutatóközpont Közgazdaság-tudományi Intézet, pp. 85-99.

Cseres-Gergely Zs. - MolnÁr Gy. (2014B): Közmunka, segélyezés, elsődleges és másodlagos munkaerőpiac. Társadalmi riport, 12:(1) pp. 204-225.

CSERES-GERGELY Zs. - MOLNÁR GY. (2015): Munkapiaci helyzet a közfoglalkoztatásból való kilépés után. In: FAZEKAS K. - VARGA J. (szerk.): Munkaerőpiaci Tükör, 2014. 
Budapest, MTA Közgazdaság- és Regionális Tudományi Kutatóközpont Közgazdaság-tudományi Intézet, pp. 143-153.

CSERES-GERGELY Zs. (2015): A közfoglalkoztatásba belépők összetétele, 2011-2012.

In: FAZEKAS K. - VARGA J. (szerk.): Munkaerőpiaci Tükör, 2014. Budapest, MTA Közgazdaság- és Regionális Tudományi Kutatóközpont Közgazdaság-tudományi Intézet, pp. 118-125.

CsOBA J. - NAGY Z. É. - SzABÓ F. (2012): Aktív eszközök, munkaerő-piaci programok kontrollcsoportos, többváltozós értékelése. In: MUNKÁCSY F. (szerk.): Kutatási Évkönyv. Összefoglalók a TÁMOP 1.3.1 kiemelt projekt keretében 2009 és 2011 között befejezett kutatásokról. Budapest, Nemzeti Munkaügyi Hivatal, pp. 102-125. CsONGOR A. (1993): Kisebbségek a periférián. In: Education, 2(2), pp. 284-286.

DAJNOKI K. (2013): Védett szervezetek megítélése a HR tükrében. In: Innovációs Szemle, 2012:(1-2.)

DERDÁK T. - VARGA A. (1996): Az iskolai nyelvezete - idegen nyelv. In: Regio: kisebbség, politika, társadalom, 7:(2) pp. 150-174.

DiEBEL A. - SzARVÁK T. (1997) A rendszerváltás vesztesei. Szociológiai vizsgálat eredményei egy határ menti falusi településen Bagamérban. In: KovÁCs T. (szerk.): IV. Falukonferencia. A fenntartható mezögazdaságtól a vidékfejlesztésig, MTA Regionális Kutatások Központja, Pécs. pp. 314-321.

DOMÁN Cs. (2014): A háztartások szokásos kiadásról alkotott véleményének modellezése regionális szinten. In: Területi Statisztika, 54:(2) pp. 119-133.

Domokos V. - HeRCZeg B. (2010): Terra Incognita: magyarországi szegény- és cigánytelepek felmérése - első eredmények. In: Szociológiai Szemle, 20(3), pp. 8299.

DURST J. (2001): „Nekem ez az élet, a gyerekek” - Gyermekvállalási szokások változása egy kisfalusi cigány közösségben. In: Századvég 2001:(6), pp. 71-92.

DURST J. (2006): Kirekesztettség és gyermekvállalás. A romák termékenységének változása néhány „gettósodó” aprófaluban. PHD értekezés. Budapest, Budapesti Corvinus Egyetem

DURST J. (2017): „De ugye biztos nem lesz ebből baj?” Posztterepmunka, kooperatív etnográfia, avagy módszertani reflexiók az informális gazdaságot övező félelem csendjének megtöréséröl. In: Szociológiai Szemle, 27:(2), pp. 88-111.

ELTE REGIONÁLIS FÖLDRAJZI TANSZÉK (2005): Regionális Tudományi Kislexikon In: Nemes Nagy J. (szerk): Regionális Elemzési Módszerek 2005, Regionális 
Tudományi tanulmányok 11. Budapest, MTA - ELTE Regionális Tudományi Kutatócsoport

ÉLTETŐ Ö. - HAVASI É. (2006): A szegénység jellemzői a kilencvenes évek közepén és napjainkban. In: KovÁCS A. - SZABÓ A. - SzOUKUP I. (szerk.): Jövedelmi helyzet, jövedelemeloszlás, 2004 (Válogatott tanulmányok). Budapest, Központi Statisztikai Hivatal, pp. 25-42.

EMIGH, R. J. - FODOR E. - SzELÉNYI I. (2001): The Racialization and Feminization of Poverty In: EMigh J., R. - SzelÉNYI I. (eds.): Poverty, Ethnicity, and Gender in Eastern Europe During the Market Transition, Westport-London: Prager Publishers

Evans, W. G. (2004): The Environment of Childhood Poverty In: The American Psychologist, 2004:(February/March)

FAINSTEIN, N. (1995): Black Ghettoization and Social Mobility. In: SMITH, M. P. Feagin, J. R. (eds.): The Bubbling Cauldrone, Edited by Minneapolis University of Minnesota Press

FALUVÉGI A. 2004: A társadalmi-gazdasági jellemzők területi alakulása és várható hatásai az átmenet időszakában. MTA KTK, Budapest, 2004:(5.) p. 18.

FARKAS Zs. - MolnÁR GY. - MolnÁR Zs. (2014): A közfoglalkoztatási csapda - A Magyar Szegénységellenes Hálózat jelentése a közfoglalkoztatottak hátteréről, helyzetéről és lehetőségeiről. Budapest, Magyar Szegénységellenes Alapítvány

FARKAS Zs. (2014): Közösségfejlesztés, mint a cigánytelepek, cigány közösségek integrációs lehetősége. In: Párbeszéd,1:(1-2)

FAZEKAS A. (2015): A közfoglalkoztatás fejlesztése a Közép-Tisza-vidéki belső periférián. In: A falu, 30(2), pp. 47-58.

FAZEKAS K. - SCHARLE Á. (2012): Munkaerő-piaci látlelet. In: FAZEKAS K. - SCHARLE Á. (szerk.) Nyugdíj, segély, közmunka: A magyar foglalkoztatáspolitika két évtizede, 1990-2010. Budapest, Budapest Szakpolitikai Elemző Intézet, MTA KRTK Közgazdaság-tudományi Intézet, Budapest, pp. 2-7.

FEJES J. B. - JÓZSA K. (2005): A tanulási motiváció jellegzetességei hátrányos helyzetű tanulók körében. In: Magyar Pedagógia, 105:(2), pp. 185-205.

FEJES J. B. - SzÜCS N. (2009): Hallgatói Mentorprogram.: A szegedi deszegregációt támogató pilot program első évének tapasztalatai. In: Új Pedagógiai Szemle, 59:(2), pp. 61-75.

Ferge Zs. - DARVAS Á. - FARKAS Zs. - TAuSz K. - VÁRnAi Gy. (2006): Gyermekszegénység elleni Nemzeti Program. In: Esély, 17:(2), pp. 71-108. 
FERGE Zs. (2000): Elszabaduló egyenlőtlenségek. Állam, kormányok, civilek. Budapest, Hilschler Rezső Szociálpolitikai Egyesület

FERGE Zs. (2006): Struktúra és szegénység. In: KovÁCH I. (szerk.): Társadalmi metszetek, érdekek és hatalmi viszonyok, individualizáció. Budapest, Napvilág Kiadó, pp. 479-500.

FiÁTH T. (2000): A magyarországi roma népesség általános iskolai oktatása - Átfogó szakirodalmi recenzió. Budapest, Delphoi Consulting

FónAi M. - FÁBiÁn G. - FiLEPNÉ NAGY É. - PÉNZES M. (2015): Szegénység, egészség és etnicitás: Északkelet-Magyarországi kutatások empirikus tapasztalatai. In: Szociológiai Szemle, 17(3-4), pp. 53-81.

FÓNAI M. - FILEPNÉ NAGY É. (2001): A roma tanulók helyzete a közoktatásban SzabolcsSzatmár-Bereg megyében. In: Educatio 2001(1) pp. 169-177.

FÓNAI M. (2016): A települési problémák és a lakossági szükségletek lehetséges hatása a helyi politikára. In: BÓDI F. - FÁBIÁN G. (szerk.): Helyi szociális ellátórendszer Magyarországon. Debreceni Egyetemi Kiadó, pp. 73-94.

ForRAY R. K. - Hegedüs T. A. (1985): Az együttélés rejtett szabályai. Egy cigány csoport sikerének mértéke és ára egy iskolában. Budapest, Országos Pedagógiai Intézet

ForRAY R. K. - HegedŰs T. A. (1991): Támogatás és integráció: oktatáspolitikai szempontok a cigányság iskoláztatásához. Budapest, Oktatáskutató Intézet

Forray R. K. - Hegedüs T. A. (2003): Cigányok, iskola, oktatáspolitika. Budapest, Oktatáskutató Intézet, Új Mandátum Könyvkiadó

FORRAY R. K. (2013): Cigány diákok a felsőoktatásban. In: Romológia, 1:(1.) pp. 8-22.

G. FEKETE É. (2005): Új esély a perifériáknak? In: Falu, Város, Régió, 2005:(1-2), pp. 43-46.

G. FEKETE É. (2006): Hátrányos helyzetből előnyök? Elmaradott kistérségek felzárkózásának lehetőségei az Észak-magyarországi régióban. In: Északmagyarországi Stratégiai Füzetek, 3:(1) pp. 54-68

G. FEKETE É. (2011): A szolidáris és szociális gazdaság elemei a magyarországi helyi gazdaságfejlesztésben. In: Észak-magyarországi Stratégiai Füzetek, 8:(2), pp. 3856.

G. FEKETE É. (2014): Dél-csereháti aprófalvak innovatív fejlesztése. In: Szellem és tudomány, 2014:(2-3), pp. 54-69. 
G. FEKETE É. (2015): Vidéki települések közötti együttmüködések. In: A Falu, 2015:(3), pp. 25-45.

G. FeKeTE É. (2016): A Postmodern Employment Model on the Peripheries. In: Theory, methodology, practice, 13:(3) pp. 41-54.

GÁbos A. - Szívós P. (2006): A gyermekszegénység néhány jellemzője Magyarországon. In: Kolosi T.-TóTH I. GY.-VuKOVICH I. (szerk.): Társadalmi Riport 2006. Budapest, TÁRKI, pp. 204-228.

Gecková, Madarasová A. - Babinská, I. - BobÁkovÁ, D. - Dankulincová Veselská, Z. - Bosáková, L. - KolarčK, P. - JarČǔKa, P. - Pella, D. Halánová, M.; HePaMeta Team (2014): Socioeconomic Characteristic of the population living in Roma settlements and their association with health-related behaviour. In: Central European Journal of Public Health, 2014:(March)

GIDDENS, A. (2008): Szociológia. Budapest, Osiris Kiadó

Gordon, D. - Adelman, L. - Ashworth, K. - Bradshaw, J. - Levitas, R. Middleton, S. - Pantazis, C. - Patsios, D. - Payne, S. - Townsend, P. WiLliams, J. (2000): Poverty and Social Exclusion in Britain. York, Joseph Rowntree Foundation

GúTI E. (2001): Romák az oktatásban. In: ANDOR M. (szerk.): Romák és oktatás. Pécs, Iskolakultúra Könyvek, pp. 54-64.

GYENEI M. (1993A) A létminimum alatt - Jajhalom (I.) In: Statisztikai Szemle, 1993 (1), pp. 16-31.

GYENEI M. (1993B): A létminimum alatt - Jajhalom (II.) In: Statisztikai Szemle, 1993 (2) pp. 130-146.

GyergyÁk J. (2011): Periféria. Pécs. Pécsi Tudományegyetem, Breuer Marcell Doktori Iskola

HAJdU M. - MAKÓ Á. - NÁBELEK F. - NYÍRÖ Zs. (2016): A munkapiaci szakpolitika eszközei (2015. május - 2016. március). In: FAZEKAS J. - KÖLLÖ J. (szerk.): Munkaeröpiaci Tükör, 2016. Budapest, MTA Közgazdaság- és Regionális Tudományi Kutatóközpont Közgazdaság-tudományi Intézet, pp. 183-196.

HAJNÁCZKY T. 2013: Az 1961-es párthatározat margójára - Dokumentumok az MSZMP KB PB 1961. Június 20-án kiadott határozatának Borsod-Abaúj-Zemplén megyei végrehajtásáról In: Múltunk, 2013:(1), pp. 237-272.

HARSÁNYI E. - RADÓ P. (1997): Cigány tanulók a magyar iskolákban. In: Eduicatio, 6:(1) 
Havas G. (1999): A kistelepülések és a romák. In: Glatz F. (szerk.): A cigányok Magyarországon. Magyarország az ezredfordulón - Stratégiai kutatások a Magyar Tudományos Akadámián. Budapest, MTA

HorvÁTH Á. (2014): Tiszabői szociográfia In: Journal of Central European Green Innovation, 2:(2) pp. 53-84.

HoRvÁTH Á. (2015): A hátrányos helyzetű diákok tanulási motivációi. In: Studia Mundi Economica, 2:(3) pp. 97-112.

HoRvÁTH Á. (2016): A migráció alulnézetből - A helyben maradás és költözés motivációi Borsod-Abaúj-Zemplén megyei településeken. In: XVI. Geográfus Doktoranduszok Országos Konferenciája, Konferenciakötet, Eszterházy Károly Egyetem, Eger

HORVÁTH Á. (2017): The power of public works programme in peripheral areas on the example of a dead-end village. In: Belvedere Meridionale, 29:(4) pp. 71-88.

HoRvÁTH Á. (2018): Maximum létminimum, Tiszabő. In: A Földgömb, 36:(321) pp. 5462.

IMREI I. (2001): A tiszabői Freinet-mühelyről. In: ANDOR M. (szerk.): Romák és oktatás. Pécs, Iskolakultúra Könyvek, pp. 129-137.

JANeVic, T. - Petrovic, O. - BJelic, I. - KuberA, A. (2010): Risk factors for childhood malnutrition in Roma settlements in Serbia. In: BMC Public Health, 2010:(August)

JANKY B. (2016) A szegénység újratermelődése: A struktúrától a kultúráig, és vissza: Gondolatok Orlando Patterson és Ethan Fosse „The Cultural Matrix: Understanding Black Youth” címü kötete kapcsán. In: Társadalomtudományi Szemle 2016:(2) pp. 89-102.

JONES, K. R. (1999): The culture of poverty and African-American Culture: An Empirical Assessment. In: Sociological Perspectives, 42:(3)

KÁLMÁN J. (2015): A közfoglalkoztatási programok háttere és nemzetközi tapasztalatai.

In: FAZEKAS K. - VARGA J. (szerk.): Munkaerőpiaci Tükör, 2014., Budapest, MTA Közgazdaság- és Regionális Tudományi Kutatóközpont Közgazdaság-tudományi Intézet, pp. 42-58.

KATANics S. - Lovassy L - Sió L. - Velkey G. - KóKAyné LÁnyi M. - RAdó P. SCHÜTTER T. (2006): Egy ember akkor tanul, akár hatévesen, akár ötvenévesen, ha szeret és tud tanulni: Részletek a Tanulás Magyarországon című OPEK nyilvános elemzés szerkesztőségi vitájából. In: Új Pedagógiai Szemle, 56:(2) pp. 29-44.

Keeble, D. - Offord, J. - Walker, S. (1988): Peripheral Regions in a Community of Twelve Member States. Luxembourg, Commission of the European Community 
KEMÉNY I. - JANKY B. - LENGYEL G. (2004): A magyarországi cigányság. 1971-2003. Gondolat Kiadó - MTA Etnikai-nemzeti Kisebbségkutató Intézet, Budapest.

KEMÉNY I. - JANKY B. (2003): A cigányok foglalkoztatottságáról és jövedelmi viszonyairól. A 2003. évi cigánykutatás alapján In: Esély, 2003:(6.) pp. 58-72.

KEMÉNY I. - RuPP K. - CsAlOG Zs. - HAVAS G. (szerk.): Beszámoló a magyarországi cigányok helyzetével foglalkozó, 1971-ben végzett kutatásról. Budapest, MTA Szociológiai Kutató Intézetének kiadványai, pp. 26-27.

Kende Á. (2000): Mindenkit lehet tanítani. Interjú Csapó Benő, a szegedi egyetem pedagógia tanszékének egyetemi tanárával. In: Amaro Drom, 10:(október)

KENDE A. (2004): Együtt vagy külön? A szegregált iskolarendszer és a speciális oktatási szükségletek megállapításának problémái. In: Iskolakultúra: Pedagógusok szakmaitudományos folyóirata, 14:(1.) pp. 3-13.

KEREKI J. - SZVATKó A. (2015): A koragyermekkori intervenció, valamint a gyógypedagógiai tanácsadás, korai fejlesztés, oktatás és gondozás szakszolgálati protokollja. Budapest, Educatio Társadalmi Szolgáltató Nonprofit Kft.

KERESZTES É. R. (2016): A humántőke-befektetés és az Európa 2020 stratégia néhány társadalmi-gazdasági összefüggése. In: Gazdaság és Társadalom, 8:(4)

KERTESI G. - KÖLLÖ J. (2001): A gazdasági átalakulás két szakasza és az emberi tőke átértékelődése. A bérszerkezet átalakulása Magyarországon 1986-1999. III. rész. In: Közgazdasági Szemle, 18:(november), pp. 897-919.

KERTESI G. - KÖLLÖ, J. (1998): Regionális munkanélküliség és bérek az átmenet éveiben A bérszerkezet átalakulása Magyarországon - II. rész. In: Közgazdasági Szemle, 45:(7-8), pp. 621-652.

KERTESI G. (1995): Cigány foglalkoztatás és munkanélküliség a rendszerváltás előtt és után (Tények és terápiák). In: Esély, 1995:(4) pp. 19-63.

KERTESI G. (2000A): A cigány foglalkoztatás leépülése és szerkezeti átalakulása 1984 és 1994 között - Munkatörténeti elemzés. In: Közgazdasági Szemle, 47:(Május) pp. 406-443.

KERTESI G. (2000B): Ingázás a falusi Magyarországon. Egy megoldatlan probléma. In: Közgazdasági Szemle, 17:(október), pp. 775-798.

KeRTESI G.- KÖLLÖ J. (2004): A 2001. évi minimálbér-emelés foglalkoztatási következményei. In: Közgazdasági Szemle, 51:(Április), pp. 293-324.

KIM - KÖZIGAZGATÁSI ÉS IgAZSÁGÜGYI MinisZtérIUM, TÁRSADALMI FELZÁRKÓZÁSÉRT FELELŐs ÁllamtitKÁRSÁG (2011) - Nemzeti Társadalmi 
Felzárkózási Stratégia - Szegénység, gyermekszegénység, romák (2011-2020). Budapest

Kiss D. - LAntos Sz. - MARozsÁn Cs. - NÉMETH N. (2013): „Jelenlét” - a roma integrációt szolgáló fejlesztések megalapozása, szociális munka kirekesztett közösségekben, szegregátumokban. PAIRS „Effective Programmes for the Active Integration/Inclusion of the Roma in South East Europe" projekt. Budapest, Magyar Máltai Szeretetszolgálat

KISS É. E. (2001): Falvaink sorsa az ezredfordulón: A Közép-Tisza vidéki tapasztalatok. In: Tér és Társadalom, 15:(1), pp. 153-169.

KISS J. P. - SzALKAI G. (2018): Az ingázás mobilitási jellemzői a legutóbbi népszámlálások adatai alapján. In: Területi Statisztika, 58:(2): pp. 177-199.

KLIGMAN, G. (2001): On the social construction of „Otherness”: Identifying „The Roma” In post-socialist communities. In: Review of Sociology, 7:(2).

Kocsis K. - KovÁCs Z. (1999): A cigány népesség társadalomföldrajza. In: GLATZ F. (szerk.): A cigányok Magyarországon. Magyarország az ezredfordulón. Budapest, MTA. pp. 17-20.

Kolarcik, P. - Madarasova Geckova, A. - Orosova, O. - Van Dijk, J. P. ReIJNEVELD, S. A. (2009): To what extent does socioeconomic status explain differences in health between Roma and non-Roma adolescents in Slovakia? In: Social Science \& Medicine, 2009:(February)

KOLTAIL. - KULINYI M. (2013): A közfoglalkoztatást szervezők értékei. Budapest, Esély Labor Egyesület

Koltai L. (2014): Közfoglalkoztatási körülmények és aktivitás. Budapest, Esély Labor Egyesület

Koltai L. (2015): Célok és értékek a közfoglalkoztatásban. In: Fundamentum, 19:(1), pp. 68-71.

Koós B. (2015A): A deprivációs folyamatok területi képe Magyarországon. In: CZIRFUSZ M. - HOYK, E. - SuVÁK A. (szerk.): Klímaváltozás - társadalom - gazdaság: Hosszú távú területi folyamatok és trendek Magyarországon. Pécs, Publikon Kiadó, pp. 179191.

Koós B. (2015B): A szegénység és depriváció a magyar településállományban az ezredfordulót követően - avagy kísérlet a települési deprivációs index létrehozására. In: Tér és Társadalom, 29:(1)

Koós B. (2016): Közfoglalkoztatás a mezőgazdaságban. In: Tér és Társadalom, 30:(3) 
Kósa Zs.- SzÉles Gy.- Kardos L., KósA K., NÉMeth R. - OrsZÁGH S. - Fésüs G. McKeE, M. - ÁDÁNY R. - VoKó Z. (2007): A Comparative Health Survey of the Inhabitants of Roma Settlements in Hungary. In: American Journal of Public Health, 2007:(May)

KovÁCS K. (2008): Kistelepülések lépéskényszerben. In: VÁRADI M. (szerk.): Kistelepülések lépéskényszerben. Budapest, Új Mandátum Könyvkiadó, MTA Regionális Kutatások Központja, pp. 7-29.

Kovács Z. - Csachová, S. - Ferenc M. - HruŠKA, V. - KonOPSKI, M. (2015B):

Development policies on rural peripheral areas in Visegrad Countries: a comparative policy analysis. In: Studia Obszarlow Wiejskich / Rural Studies, 39. pp. 77-101.

KovÁcs Z. - EgEdy T. - Földi Zs. - KERESZTÉLy K. - SZABÓ B. (2007): Budapest: from state socialism to global capitalism: pathways to creative and knowledge-based regions. Amsterdam, University of Amsterdam, AMIDSt

KovÁcs Z. - EgEDy T. - SzABÓ B. (2015A): Az ingázás területi jellemzőinek változása Magyarországon a rendszerváltozás után. In: Területi Statisztika, 55:(3), pp. 233253.

KovÁcs Z. - SZABÓ B. - SzÉKElY G. (2005): A lakáspiaci dinamizmus néhány jellemzője Magyarországon. In: Statisztikai Szemle, 83:(5), pp. 461-479.

KovÁCS Z. (1999) Alföldi nagyvárosok társadalmi térszerkezetének vizsgálata. In: Alföldi Tanulmányok 17, pp. 52-72.

KovÁcs Z. (2017): Városok és urbanizációs kihívások Magyarországon. In: KovÁcs Z. (szerk.): Magyar Tudomány, Társadalom - Földrajz 178:(3), pp. 302-310.

KÖLLŐ J. - SCHARLE Á. (2011): A közcélú foglalkoztatás kibővülésének hatása a tartós munkanélküliségre. In FAZEKAS KÁROLY - KÉZDI GÁBOR (szerk.): Munkaerő-piaci Tükör 2011. Budapest, MTA KTI - OFA, pp. 145-160.

KÖLLŐ J. (2015): Hol dolgoznak a közmunkások? In: FAZEKAS K. - VARGA J. (szerk.): Munkaerőpiaci Tükör, 2014. Budapest: MTA Közgazdaság- és Regionális Tudományi Kutatóközpont Közgazdaság-tudományi Intézet, pp. 154-159.

KÖSzEGFALVI Gy. (2009): Törekvések a magyarországi településrendszer tudatos fejlesztésére. Az Országos Településhálózat-fejlesztési-koncepció. In: Területi Statisztika, 12:(49), pp. 571-584.

KSH - KÖZPONTI STATISZTIKAI HIVATAL (2009): Foglalkoztatottság és munkanélküliség 2009. Június - augusztus. KSH 156. Gyorstájékoztató 2009. szeptember KSH - KÖZPONTI STATISZTIKAI HiVATAL (2012): Létminimum, 2011. Budapest, KSH 
KSH - KÖZPOnTI StatiszTiKai Hivatal (2013): 2011-es Népszámlálás 3. Területi Adatok 3.11. Jász-Nagykun-Szolnok megye, Debrecen

KSH - KÖZPONTI StATISZTIKAi HivATAL (2014): A háztartások életszínvonala, 2014. November

KSH - KÖZPONTI StATISZTIKAI HivatAL (2015): Magyarország közigazgatási helynévkönyve. Budapest, 2015. január 1.

KSH - KÖZPONTI StATISZTIKAi HiVATAL (2016B.): Magyarország, 2016. Budapest

KSH - KÖZPONTI StatiszTiKai Hivatal (2017): Mikrocenzus 2016 - Demográfiai adatok, Budapest

KULCSÁR L. - KULCSÁR J. L. - OBÁDOVICS Cs. (2011): Who lives in forgotten places? Age Structure and Socio-economic Development. In: Regional Statistics, 14, pp. $110-121$.

KulcsÁr L. - KulcsÁr J. L. - OBÁdovics Cs. (2011): Who lives in forgotten places? Age structure and socio-economic development in Hungary. In: Regional Statistics, 14, pp. 110-121.

LADÁNYI J. - SZELÉNYI I. (2001): The social construction of Roma ethnicity in Bulgaria, Romania and Hungary during market transition In: Review of Sociology, 7:(2.)

LADÁNYI J. - SZELÉNYI I. (2004): A kirekesztettség változó formái. Budapest, Napvilág Kiadó

LADÁNYI J. - VIRÁG T. (2009): Szociális és etnikai alapú lakóhelyi szegregáció változó formái Magyarországon a piacgazdaság átmenet időszakában. In: LADÁNYI JÁNOSCSANÁdi G. - CSEPELI GY. - SzELÉNYI I. - NEMESKÉRY A. (szerk.): Társadalom és térszerkezeti átalakulások - Válogatott tanulmányok (1975-2010). A gazdasági élet szociológiája. TÁMOP - 4.1.2-08/2/A/KMR-0043 SZOCMEG project, pp. 184199.

LAdÁNYI J. (2001): The Hungarian Neoliberal State, Ethnic Classification, and the Creation of a Roma Underclass In: EMIGH J., R. - SzELÉNYI I. (eds.): Poverty, Ethnicity, and Gender in Eastern Europe During the Market Transition, WestportLondon, Prager Publishers

LADÁNYI J.-SZELÉNYI I. (2005): Az újrakörzetesítés társadalmi ára. In: Kritika, 34: (1.) pp. 2-5.

LANDAU E. (1997): Bátorság a tehetséghez. Budapest, Calibra Kiadó

LENGYEL G. (2006): Cigánytelepek egykor és ma. In: KÁLlAI E. - TÖRZSÖK E. (szerk.): Átszervezések kora. Cigánynak lenni Magyarországon. Jelentés 2002-2006. Budapest, Európai Összehasonlító Kisebbségkutatások Közalapítvány, p. 71. 
LENGYEL I. (1991): Alföldi Társadalom. 2. kötet. Békéscsaba, MTA Regionális Kutatások Központja

LEVELEKI M. (2012): Területi egyenlőtlenségek, társadalmi hátrányok és az ingázás a statisztikák tükrében. In: SZRETYKÓ GYÖRGY (szerk.): Gazdasági kannibalizmus Hátrányos helyzetű csoportok a munkaerőpiacon és az emberi erőforrás menedzsment. Pécs, Comenius

LEwIS, O. (1959): Five families: Mexican Case Studies in the Culture of Poverty. New York, Basic Books

LEwIS, O. (1965): The Children of Sanchez. Harmondsworth, Penguin Books

LEWIS, O. (1966): The Culture of Poverty. In: GMELCH, G. - ZENNER, W. (eds.): Urban Life. Waveland Press

LEWIS, O. (2000): A szegénység kultúrája. In: BAUER B. (2000): Süsü a társadalomban. Társadalomismereti olvasókönyv, Budapest, Új Mandátum Kiadó

LIPTÁK K. (2014): Az Észak-magyarországi régió munkaerő-piaci folyamatainak vizsgálata. In: Competitio, 13:(2), pp. 84-102.

LISKÓ I. (2001): A cigány tanulók és a pedagógusok. In: ANDOR M. (szerk.): Romák és oktatás. Pécs, Iskolakultúra Könyvek, pp. 3-14.

LÖCSEI H. - SZALKAI G. (2008): Helyzeti és fejlettségi centrum - periféria relációk a hazai kistérségekben. In: Területi Statisztika, 48:(3), pp. 305-314.

Ludescher G. (2017): A vidék változása. In: Acta Medicina et Sociologica, 8:(25), pp. 26-43.

Magyari N. L. - Magyari-Vincze E. - Popescu, L. - Rotariu, T. (2001): The social Construction of Romanian Poverty: The Impact of Ethnic and Gender Distincton In: EMIGH, J. R. - SzELÉNYI I. (eds.): Poverty, Ethnicity, and Gender in Eastern Europe During the Market Transition. Westport-London, Prager Publishers

MARgitics F. - PAUWLIK Zs. (2006): Megküzdési stratégiák preferenciájának összefüggése az észlelt szülői nevelői hatásokkal. In: Magyar Pedagógia, 106:(1), pp. 43-62.

Maslow, A. H. (1943): A Theory of Human Motivation. In: Psychological Review, 50. pp. 370-396.

Merton, R. K. (1980): Társadalomelmélet és társadalmi struktúra. Budapest, Gondolat Kiadó

Messing V. - MolnÁR E. (2010): A szegény családok megélhetési stratégiái regionális és etnikai metszetekben. OTKA Projektjelentés. 
Messing V. (2012): Kettévágott munkapiac, szétforgácsolt társadalom. Avagy hogyan dezintegrálják a magyar munkaerő-piacot és a társadalmat az állami foglalkoztatáspolitikai beavatkozások, különös tekintettel a közfoglalkoztatási programokra. In: KovÁch I. - DuPCSIK Cs. - P. TÓTH T. - TAKÁCS J. (szerk.): Társadalmi integráció a jelenkori Magyarországon - Tanulmányok. MTA Társadalomtudományi Kutatóközpont, Szociológia Intézet, Argumentum Kiadó

Mitev, P. E. - Tomova, I. - Konstantinova, L. (2001): The price of Procrastination? The Social Costs of Market Transition in Bulgaria In: EMIGH J., R. - SzELÉNYI I. (eds): Poverty, Ethnicity, and Gender in Eastern Europe During the Market Transition, Westport-London: Prager Publishers

Mollenhauer, K. (1974): Szocializáció és iskolai eredmény. In: Ferge Zs. - HABER J. (szerk.): Az iskola szociológiai problémái. Budapest, Közgazdasági és Jogi Könyvkiadó, pp. 189-216.

MOLNÁR E. (2017): A félperiféria szerepe az élőmunka-igényes ágazatok globális értéktermelési hálózataiban. In: Területi Statisztika, 57:(4), pp. 436-464.

Moser, C. O. N. (1998): The Asset Vulnerability Framework: Reassessing Urban Poverty Reduction Strategies. In: World Development, 26:(1.)

MTA - Magyar Tudományos Akadémia Regionális Kutatások KÖZPontua ALFÖLDI TUDOMÁNYOS INTÉZETÉNEK SZOLNOKI TÁRSADALOMKUTATÓ CSOPORTJA (2004): Helyzetfeltárás a „Roma integrációs program, különös tekintettel a halmozottan hátrányos helyzetű rétegek életesélyeinek javítására” címü tervezési dokumentumhoz, 2004. Június

NAGy E. - NAGY G. - DudÁs G. (2016): The uneven transformation of consumption spaces and the rise of new marginalities in Hungary. In: Regional Statistics, 6:(2.) 149-172.

NAgy E. - TímÁR J. - NAgY G. - Velkey G. (2015A): A társadalmi-térbeli marginalizáció folyamatai a leszakadó vidéki térségekben. In: Tér és Társadalom, 29:(1)

NAgy E. - TimÁr J. - NAgy G. - Velkey G. (2015B): The everyday practices of the reproduction of peripherality and marginality in Hungary. In: LANG, T. - HENN, S. ERLiCH, K. - SGIBNEV, W. (eds.): New geo graphies of Central and Eastern Europe. London, Palgrave Macmillan

NAGY G. (2004): A gazdasági távolság meghatározása potenciálmodell segítségével. In: Területi Statisztika, 44:(1), pp. 31-40. 
NAGY G. (2006): A magyar gazdaság területi folyamatainak mérlege: erősödő területi különbségek, vs. regionális kiegyenlítődés. In: KISS A - MEZÖSI G - SÜMEGHY Z (szerk.): Táj, környezet és társadalom: ünnepi tanulmányok Keveiné Bárány Ilona professzor asszony tiszteletére. Szeged, SZTE Éghajlattani és Tájföldrajzi Tanszék; SZTE Természeti Földrajzi és Geoinformatikai Tanszék, pp. 529-540.

NAGY GY. (2012): Környezeti igazságtalanság a kárpát-medencei kisebbségek körében. In: A Virtuális Intézet a Közép-Európa Kutatására Közleményei, 4:(3) pp. 170-177. Nemes Nagy J. (1998): Vesztesek, nyertesek, stagnálók. Társadalmi Szemle, 58:(8-9) pp. 5-18.

NEMES NAGY JÓZSEF (1996): Centrumok és perifériák a piacgazdasági átmenetbe. In: Földrajzi Közlemények, 120:(4.) pp. 31-48.

OBÁDOVics Cs. - BRUdER E. - KulcsÁR L. (2012): Territorial inequalities of economic and welfare situation in rural Hungary - similarities and differences. In: BóDI F.FÁBIÁN G. - LAWSON T. L. (eds): Local Organisation of Social Services in Hungary. Crises - Reactions - Changes. Bremen, Studies in Comparative Social Pedagogies and International Social Work and Social Policy Vol. XXII. EHV GmbH \& Co. KG. pp. 163-178.

OLÁH A. (2014): Hátrányos helyzetü településrészeket, családokat támogató programok eredményessége a pécsi György-telep példáján. In: Ablak a világra tanulmánykötet. Pécsi Tudományegyetem BTK NTI Romológia és Nevelésszociológia Tanszék, Wlislocki Henrik Szakkollégium, pp. 85-94.

PÁL V. (2013): A perifériahelyzet és az egészségi állapot - egy ormánsági kutatás tapasztalatai. In: A Falu, 2013:(1), pp. 29-41.

PÁL V. (2017): Egészségünk földrajza - területi különbségek a hazai egészségi állapotban. In: KovÁCs Z. (szerk.): Magyar Tudomány, Társadalom - Földrajz 178:(3), pp. 311-321.

PÁlÓCZi Á. - KoZMA G. (2016): A roma lakosság a foglalkoztatás- és szociálpolitika tükrében. In: SzILÁGYi F. - PÉNZES J. (szerk.): Roma népesség Magyarország északkeleti határtérségében. Partium Kiadó, Nagyvárad, pp. 109-126.

PÁlóczi G. (2016): A munkaerőpiaci ingázás vizsgálati lehetőségei komplex hálózatelemzéssel. In: Területi Statisztika, 56:(2), pp. 118-138.

PAPP S. - NAGY Gy. - Boros L. (2017): A kedvezményezett települések objektív életminőség alapján történő lehatárolási lehetőségei. In: Területi Statisztika, 57:(6), pp. 639-664. 
PÁSZTOR I. Z. - PÉNZES J. (2012): Foglalkoztatási krízis és jövedelmi periferizálódás Északkelet-Magyarországon a roma népesség arányának tükrében. In: Területi Statisztika, 52:(4), pp. 353-371.

PÁSZTOR I. Z. - PÉNZES J. (2018): A cigányság lélekszáma és helyzete egy Északkeletmagyarországi felmérés tükrében. In: Földrajzi Közlemények, 142:(2.) pp. 154-169.

PÁSZTOR I. Z. (2013): Társadalomföldrajzi vizsgálatok az északkelet-magyarországi cigányság körében (Létszámváltozások, önkormányzatiság, kisebbségi választások). Doktori disszertáció. Debrecen, Debreceni Egyetem, Földtudományok Doktori Iskola

Patterson, O. - Fosse, E. (2015): Introduction. In: Patterson, O. - Fosse, E. (szerk.) The Cultural Matrix: Understanding Black Youth. Harvard University Press, pp. 125.

PÉnzes J. - DeÁK A. - Hegedüs L. D. (2018B): Periférikusság és határmentiség Magyarországon. In: PÉNZES J. (szerk.): Falu - város - periféria: határon innen és túl: Süli-Zakar István professzor emlékére. Debrecen: Didakt Kiadó, pp. 227-235.

PÉnZES J. - MolnÁR E. - PÁLÓCZI G. (2014): Helyi munkaerő-piaci vonzáskörzetek az ezredforduló utáni Magyarországon. In: Területi Statisztika, 54:(5) pp. 474-490.

PÉnZes J. - TÁTRAi P. - PÁsZTOR I. Z. (2018A): A roma népesség területi megoszlásának változása Magyarországon az elmúlt évtizedekben. In: Területi Statisztika, 58:(1), pp. 3-26.

PÉNZES J. (2010): Az Észak-alföldi régió periférikus térségeinek tagolódó tényezői a rendszerváltás után, különös tekintettek a területi jövedelemegyenlőtlenségekre. Doktori disszertáció. Debrecen, Debreceni Egyetem, Földtudományok Doktori Iskola

PÉNZES J. (2013): A foglalkoztatottság, az ingázás és a jövedelmi szint összefüggései Északkelet- és Északnyugat-Magyarországon. In: Területi Statisztika, 53(3), pp. 202-224.

PIK K. (2001): A cigány gyerekek és az óvoda esete - II. In: Esély, 12:(1), pp. 4-69.

PONGRÁCz T. - S. MolnÁR E. (1994): Serdülőkorban szült anyák társadalmi, demográfiai jellemzőinek vizsgálata. KSH Népességtudományi Kutató Intézetének jelentései, Budapest

RÁCZ A. - LÉNÁRD K. (2003): A javítóintézeti nevelés dezintegrációs hatása In: Kapocs 2:(5) 
RÁCZ A. (2014): Szegregáció a fejekben. A statisztikai és a mentális társadalmi és térbeli elkülönülés vizsgálata Szegeden. Központi Statisztikai Hivatal, Műhelytanulmányok 4., Budapest

RADÓ P. (1997): Jelentés a magyarországi cigány tanulók oktatásáról. Szakértői tanulmány a Nemzeti Etnikai Kisebbségi Hivatal számára. Budapest, Kézirat

RAPHAEL, D. (2002): Poverty, Income Inequality and Health in Canada. Social Justice Series, CSJ Foundation for Research and Education

ROZGONYI-HORVÁTH Á. (2018): A periférikus területeken élő aktív korúak munkaerőpiaci kapcsolatai - egy belső periférián található zsáktelepülés példáján. In: Területi Statisztika, 58:(4), pp. 417-443.

RUdOLFNÉ KATONA M. (2015): A fogyasztói magatartás és az elégedettség főbb tényezői a vendéglátásban. Gödöllő, Szent István Egyetem

SÁGHY E. (1995): Peremhelyzetben. Alternatív pedagógiai módszerek esélyé a cigány gyermekek oktatásában. In: Iskolakultúra, 1995:(6-7.)

SAMman, E. - SANTOS, M. E. (2013): Poor and dissatisfied? Income poverty, poverty transitions and life satisfaction in Chile In: Journal of Poverty and Social Justice, 21:(1)

SCHARLE Á. (2012): Reménytelen vagy tartós munkanélküliség? Az erősebb járási szint egy lehetséges előnyéröl. In: Fundamentum, 16: (2.) pp. 29-33.

SCHARLE Á. (2015): A közfoglalkoztatás Szlovákiában. In: FAZEKAS K. - VARGA J. (szerk.): Munkaerőpiaci Tükör, 2014. MTA Közgazdaság- és Regionális Tudományi Kutatóközpont, Közgazdaság-tudományi Intézet, Budapest. pp. 59-60.

SCHARLE Á. (2016): Mennyit nőtt a foglalkoztatás 2008 óta Magyarországon? In: KoLOSI T. - TÓTH I. GY. (szerk.): TÁRKI Társadalmi Riport, 2016. Budapest, TÁRKI, Társadalomkutatási Intézet Zrt., pp. 54-72.

SCHMIDT, M. (2007): The influence of scale on the basic dimensions and indicators of marginality. In: JONES, G., LEIMGRUBER, W., NEL, E. (eds.): Issues in geographical marginality. Grahamstown, Rhodes University, pp. 52-65.

SEBESTYÉN I. (2002): Tiszabő történeti demográfiája a helyi katolikus anyakönyvek számítógépes feldolgozása alapján (1737-1799) In: KÖZPONTI STATISZTIKAI Hivatal: Történeti Demográfiai évkönyv. Budapest, Népességtudományi Kutatóintézet, pp. 201-248.

SEMJÉN A. (1996): A pénzbeli jóléti támogatások ösztönzési hatásai. In: Közgazdasági Szemle, 43:(10), pp. 841-862. 
SiPOSNÉ NÁNDORI E. (2012): A jövedelmi szegénység térökonometriai elemzése az Észak-magyarországi régióban. In: BOTTLIK Zs. - CZIRFUSZ M. - GYAPAY B. KöSzegi M. - PfEning V. (szerk.): Társadalomföldrajz - Területfejlesztés Regionális Tudomány. Budapest, ELTE TTK Földtudományi Doktori Iskola, pp. 145-158.

SIPOSNÉ NÁNDORI E. (2016): A munkaerőpiaci hátrányok területi vonatkozásai ÉszakMagyarországon. In: Területi Statisztika, 56:(4), pp. 438-454.

SIPTÁR D. - TÉSITS R. - ALPEK B. L. (2016): Cultural and regional characteristics of the poverty segregations: Based on the examples of Hungarian peripheral regions. In: Easetern European Countryside, 22:(1), pp. 107-134.

SIPTÁR D. - TÉSITS R. (2014): A szegénységi szegregáció területi jellegzetességei Baranya megyében. In: Humán Innovációs Szemle, 5:(1-2.) pp. 139-162.

SMF - Statisztikai Módszertani FüzeteK, 47 (2006): A háztartás és a család fogalma. Budapest, Központi Statisztikai Hivatal

SolT Á. (2010): Élet a reményen túl - Szegregált telepen élők mentalitásvizsgálata. In: Szociológiai Szemle, 20:(3), pp. 100-133.

SPÉDER Zs. (2002): A szegénység változó arcai - Tények és értelmezések, Századvég Kiadó

STATISZTIKAI TÜKÖR (2008): A keresetek alakulása Magyarországon és az unióban 2007.

2: (84.) 2008. június 27., KSH - Központi Statisztikai Hivatal

STATISZTIKAI TÜKÖR (2015): Munkaerő-piaci folyamatok 2014 I-IV. negyedév. 2015/19. 2015. március 6. KSH - Központi Statisztikai Hivatal

STATISZTIKAI TÜKÖR (2017): Munkaerő-piaci folyamatok 2016. I-IV. negyedév. 2017. április $12 . \mathrm{KSH}-\mathrm{Központi} \mathrm{Statisztikai} \mathrm{Hivatal}$

SteEdMAn, H. - McInTOsh, S. (2001): Measuring low skills in Europe: how useful is the ISCED framework? In: Oxford Economic Papers, 53:(3), pp. 564-581.

STENNING, A. (2005): Where is the Post-socialist Working Class? - Working-Class Lives in the Spaces of (Post)Socialism. In: Sociology, 39:(5)

STEWART, M. (2002): Deprivation, the Roma and „the Underclass”. In: HANN, C. (ed.): Postsocialism, Ideals, Ideologies and Practices in Eurasia. New York, Routledge, pp. 133-157.

Sutherland, E. H. - CRessey, D. R. - LuCKenbill, D. (1984): The Theory of Differential Association. In: HERMAN, N. J. (1995): Deviance - A Symbolic Interactioniset Approach. Oxford, General Hall, Rowman and Littlefield Publisher 
SÜLI-ZAKAR I. - LENKEY G. (2014): A vidék mint földrajzi periféria és az oktatás mint kitörési pont. In: Educatio, 2014: 23:(3), pp. 371-383.

SÜLI-ZAKAR I. (1997): A fenntarthatóság és a társadalmi-gazdasági fejlődés esélye az alföldi falusi térségekben. In: Alföldi tanulmányok, MTA Regionális Kutatások Központja Alföldi Tudományos Intézet, Békéscsaba, pp. 77-93.

SÜLI-ZAKAR I. (2013): A cigányság integrációjának szociálgeográfiai követelményei. In: Közép-Európai Közlemények. Történészek, geográfusok és regionalisták folyóirata, 6:(1-2), pp. 150-167.

SÜLI-ZAKAR I. (2016): The formation of social and economic peripheries in Hungary after the change of regime. In: Landscape \& Environment, 10:(3-4), pp. 179-187.

SYKORA, L. (2009): Post-socialist cities. In: KITCHIN, R. - THRIFT, N. (eds): International Encyclopedia of Human Geography, Vol. 8. pp. 387-395.

SzABÓ A. (2013): A közfoglalkoztatás jelentősége két gazdasági recesszió tükrében. In: Esély, 2013:(4) pp. 73-86.

SzABÓ B. (2005): Az Észak-Alföld régió szociális helyzetelemzése. In: Kapocs, 4:(18)

SzABÓ M. - BERDE Cs. (2007): Esélyegyenlőség az emberi erőforrás menedzsmentben.

In: BERDE Cs. - DAJNOKI K. (szerk.): Esélyegyenlőségi Emberi Erőforrás Menedzsment. Campus Kiadó, Debrecen, pp. 9-23.

SzARVÁK T. (2000): Egyes leszakadó társadalmi csoportok modernizációs törekvései. In: Tér és Társadalom, 14:(1),pp. 51-68.

SzARVÁK T. (2007): Szolnok szociális térképe In: Szolnoki Tudományos Közlemények XI.

SZÁSZVÁRI K. (2011): Az idősödő munkavállalókkal kapcsolatos sztereotípiák. Doktori disszertáció. Pécsi Tudományegyetem, Bölcsészettudományi Kar, Pszichológia Doktori Iskola

SZILÁGYI D. - GERSE J. (2015): Fokról-fokra a települési lépcsőn - Társadalmi-gazdasági különbségek a településhierarchia-szintek között Magyarországon. In: Területi Statisztika, 55:(2), pp. 180-198.

SZILÁGYi Zs. (2015): A települések közti kapcsolatok az Alföldön a 20. század első harmadában, 1. rész. Feltételek és kontextusok teremtése az alföldi falvak laterális kapcsolatainak elemzéséhez. Debrecen, Debreceni Egyetem, Bölcsészettudományi Kar, Történelmi Intézet, Modernkori Magyar Történeti Tanszék 
SzIRMAI V. (2015): Hogyan juthatunk el a területi egyenlőtlenségektől a társadalmi jóllétig? In: SzIRMAI V. (szerk.): A területi egyenlötlenségtől a társadalmi jól-lét felé. Székesfehérvár, Kodolányi János Főiskola, pp. 417-429.

SzŐKE J. (1998): A Józsefvárosi Tanoda. Budapest, Soros Oktatási Füzetek

SzUHAY P. (1999): A magyarországi cigányok kultúrája: etnikus kultúra vagy a szegénység kultúrája. Budapest, Panoráma Kiadó

TARKOWsKa, E. (1997): An Underclass without Ethnicity: The Poverty of Polish Women and Agricultural Laborers. In: EMIGH J., R. - SzELÉNYI I. (eds): Poverty, Ethnicity, and Gender in Eastern Europe During the Market Transition. Westport-London, Prager Publishers

TÁTRAi P. (2014): Etnikai folyamatok Magyarországon az ezredforduló után. In: Területi Statisztika, 54:(5), pp. 506-523.

TÉSITS R. - AlPEK B. L. - HovÁNYI G. (2018): A komplex, országos humánerőforrásfejlesztés néhány tapasztalata a konvergenciarégiókban. In: Szociálpedagógia: Nemzetközi Szaklektorált Folyóirat, 6:(1-2), pp. 86-103.

TÉSITS R. - ALPEK B. L. - KUN A. (2015): Az új típusú szociális szövetkezetek területileg eltérő foglalkoztatási szerepe. In: Területi Statisztika, 55:(3), pp. 254-272.

TÉSITS R. - ALPEK B. L. (2013): A leghátrányosabb helyzetü álláskeresők mobilitásvizsgálatának új módszerei. In: Humán Innovációs Szemle, 4:(1-2), pp. 4664.

TÉSITS R. - ALPEK B. L. (2014): Változó funkciók, célok és fejlesztési lehetőségek: A közfoglalkoztatás területileg eltérő lehetőségei Magyarországon 2. In: Szociálpedagógia: Nemzetközi Szaklektorált Folyóirat, 2:(3-4), pp. 84-96.

TÉSITS R. - ALPEK B. L. (2015): A közfoglalkoztatásban részt vevők esélyei és preferenciái: A közfoglalkoztatás területileg eltérő lehetőségei Magyarországon 3. In: Szociálpedagógia: Nemzetközi szaklektorált folyóirat, 3:(1-2), pp. 110-115.

TÉSITS R. - ALPEK B. L. (2017): Social Innovations for the Disadvantaged Rural Regions: Hungarian Experiences of the New Type Social Cooperatives. In: Easetern European Countryside, 23:(1), pp. 27-49.

TÉSITS R. - KERESZTES L. L. (2008): The ability of regional labour market adjustment in the villages of Baranya. In: Geografski Vestnik, 80:(2), pp. 107-116.

TÉSITS R. (2007A): Regional Tendencies of the Typical and Atypical Emloyment Forms in the European Union. In: Rodina a Práca / Family and Labour, (6) pp. 5-48.

TÉSITS R. (2007B): Regional employment characteristics of the most underdeveloped Hungarian Microregions. In: Modern Geográfia, 2:(2), pp. 51-85. 
THÉKES I. (2016): Az OKM adatainak feldolgozása fejlesztő pedagógiai beavatkozás céljából a komplexen fejlesztendő járásokban. In: BRATINKÁNÉ MAGYAR É. (ed.) Budapest, Türr István Képző és Kutatóintézet, pp. 22-48.

TimÁr J. - KovÁCS K. - VÁRAdi M. M. (2015): Jól-lét deficit a hátrányos helyzetü kistérségekben. In: SzIRMAI V. (szerk.): A területi egyenlőtlenségtől a társadalmi jól-lét felé. Székesfehérvár, Kodolányi János Főiskola, pp. 269-283.

TÍMÁR J. - NAGY E. - NAGY G. - VelKey G. (2015): A társadalmi-térbeli marginalizáció folyamatai a leszakadó vidéki kistérségekben. In: Tér és Társadalom, 29:(1), pp. 3552.

TimÁR J. - Velkey G. - NAGY T. (2012): SEMIGRA - Szelektív vándorlás és kiegyenlítetlen nemi arányok a rurális térségekben: Esettanulmány. vezetői összefoglaló. Békéscsaba, MTA Közgazdaság- és Regionális Tudományi Kutatóközpont. Regionális Kutatások Intézete, Alföldi Tudományos Osztály.

TÍMÁR J. - VelKey G. (2016): The relevance of the political economic approach: The interpretations of the rural in the migartion decision of young women and men and economically backward region. In: Journal of Rural Studies, 2016:(43), pp. 311-322.

TóTH B. I. (2014): A hazai kistérségek vonzerejének és területi tőkéjének néhány összefüggése. In: Területi Statisztika, 54:(1), pp. 3-18.

TÓTH G. - HAJNÁCZKY T. - BOZSONYI K. (2012): A szegregációs folyamat egy sajátos modellje - A szegregációs folyamat történeti rekonstrukciója és annak matematikai modellje Tiszabő település esetén. In: BACSÁK D. - KRÁMER L. - SZABÓ M. (szerk.): Kulcskérdések a társadalomtudományban. Budapest, ELTE TÁTK, pp. 201-222.

Tóth J. - Méreiné Bereki B. - MÁlovics Gy. - JuHÁsz J. - Boros L. (2017): „Ha csak úgy kiköltöztetjük az embereket, egymás nélkül elvesznek.” Erőforrások, korlátok és ezek térbelisége a roma szegregátumokban lakók számára: egy hazai város példája. In: Tér és Társadalom, 31:(3), pp. 62-84.

TownSEND, P. (1979): Poverty in the United Kingdom - A Survey of Househol Resources and Standards of Living. Harmondsworth, Penguin Books Ltd

Tremlett, A. (2005): Gypsy children can't learn: Roma in the Hungarian Education System. In: Goddard, J. - McNAmeE, S. - JAmeS, Ad. - JAMES, Al. (eds): The Politics of Childhood. International Perspectives, Contemporary Developments. Palgrave Macmillen, pp. 145-165.

UNICEF (2007): Child poverty in perspective: An overview of child well-being in rich countries - A comprehensive assessment of the lives and well-being of children and adolescents in the economically advanced nations, Health, Education, Equality, 
Protection, Innocenti Report Cards 7. Florence, UNICEF Innocenti Research Centre, The United Nations Children's Fund

VALUCH T. (2014): A rendszerváltás hatásai a magyar társadalom térbeliségére. In: Metszetek, 3:(2.) pp. 108-118.

VÁMOSI T. (2005B): Hátrányos helyzet újratermelődése a szakképzés rendszerében. In: Szakoktatás, (7), pp. 23-26.

VÁRADI M. M. (2014): Szegénység és projektvilág. In: NAGY E. - NAGY G. (szerk.): Polarizáció - függőség - krízis. Békéscsaba, MTA KRTK RKI Alföldi Tudományos Osztály, pp. 10-17.

VÁRADI M. M. (2015): Szegénység, projektek, közpolitikák. In: Tér és Társadalom, 29:(1), pp. 69-96.

VÁRADI M. M. (2016A): Értékteremtő közfoglalkoztatás periférikus vidéki terekben. In: Esély, 2016: (1.) pp. 30-56.

VÁRADI M. M. (2016B): Földből élők és értékteremtő közfoglalkoztatás - helyi nézőpontok. In: KovÁCS K. (szerk): Földből élők - Polarizáció a magyar vidéken. Budapest, Argumentum Kiadó

VÁRADI M. M. (2010): A közfoglalkoztatás útjai és útvesztői egy aprófalvas kistérségben. In: Esély, 2010: (1), pp. 79-100.

VArga P. - Armann Zs. - Kulinyi M. - TAKÁcs Z. - Kovács M. (2013): Közfoglalkoztatás biztonságosan. Budapest, Esély Nonprofit Kft

VASÁRUS G. (2016): Külterületi szuburbanizáció és szegregáció - Példák vidéki agglomerációk konfliktusaira. In: Településföldrajzi Tanulmányok, 5:(1)

VASECKA, M. - RAdiCOVA, I. (2000): Redistribution's Role in Leveling Income: The Overgrown Slovak Welfare State In: EMIGH J., R. - SzELÉNYI I. (eds): Poverty, Ethnicity, and Gender in Eastern Europe During the Market Transition, WestportLondon, Prager Publishers

VÁTI - VÁTI MAgYAR REgIONÁLIS FEJLESZTÉSI ÉS URBANISZTIKAI KHT. (2004): Az infrastruktúra szerepe a területi fejlődésben, a térszerkezet és az infrastruktúra fogalmai. VÁTI Kht. Területfejlesztési Igazgatóság, Elemző és értékelő iroda

VELKEY G. (2001): A területfejlesztés gyakorlata a területi érdekek és a pártpolitika erőterében. In: Alföldi tanulmányok, 2000/2001:(18), pp. 109-126.

VELKEY G. (2011): A (szak)képzés hazai rendszere, működési zavarai és megújítása. Doktori disszertáció. Pécsi Tudományegyetem, Közgazdaságtudományi Kar, Regionális Politika és Gazdaságtan Doktori Iskola 
VELKey G. (2013): Dinamikus egyensúlytalanság: A hazai közoktatási rendszer szétesése, felforgatása és a konszolidáció esélye. Pécs, Békéscsaba, MTA KRTK Regionális Kutatások Intézete

VELKEy G. (2014A): A helyi foglalkoztatás és a közfoglalkoztatás legfontosabb jellemzői egy empirikus kutatás tükrében. In: NAGY E. - NAGY G. (szerk.): Polarizáció függőség - krízis: Eltérő térbeli válaszok. Békéscsaba, MTA KRTK RKI Alföldi Tudományos Osztály, pp. 28-39.

VELKEY G. (2014B): A közszolgáltatások szervezése marginalizálódó térségekben. In: VII. Magyar Földrajzi Konferencia: absztraktkötet. Miskolc, Miskolci Egyetem Müszaki Földtudományi Kar, pp. 63-64.

VELKEY G. (2014C): A tanulás szerepe a marginalizálódó térségek fejlesztésében. In: Educatio, 23:(3.) pp. 415-423.

VERES L. (2004): Belső perifériák jelene és jövője - Társadalmi és gazdasági térszerkezet Magyarországon. In: Ma és Holnap, 4:(3) pp. 35-37.

VERESNÉ Somosi M. - KocZISZKY Gy. - FodORNÉ StUnyA E. (2016): A szegregációk kialakulásának okai és kezelésének lehetőségei Miskolcon. In: Észak-magyarországi Stratégiai Füzetek, 13:(1), pp. 32-56.

VIRÁG T. (2006): A gettósodó térség. In: Szociológiai Szemle, 2006:(1.) pp. 60-76.

VIRÁG T. (2009): Szegények a kistelepülések fogságában - a szociálpolitika mindennapi gyakorlata egy hátrányos helyzetü kistérség településein. In: Esély, 2009:(4), pp. 3854.

VIRÁG T. (2010): Kirekesztve. Falusi gettók az ország peremén. Budapest, Akadémiai Kiadó

WACQuant, L. (2004): What is a Ghetto? Constructing a Sociological Concept. In: SMELSER, N. J. - BALTES, P. B. (eds.): International Encyclopedia of the Social and Behavioral Sciences. London, Pergamon Press

WACQUANT, L. (2011): Lakóhely szerinti megbélyegzés a fejlett marginalitás korában. In: Fordulat, 13. pp. 12-27.

WALLERSTEIN, I. (1983): A modern világgazdasági rendszer kialakulása: a tőkés mezőgazdaság és az európai világgazdaság eredete a XVI. században. Gondolat Kiadó, Budapest

WARZYWODA-KRUSZYNSKA, W. (2000): Document 36: Long-Term Unemployment and Hard-Core Poverty in a Polish Industrial City. Sofia, UNESCO-MOST

ZAFír M. (1997): Az új létminimum-számítás - Küszöbértékek. In: Statisztikai Szemle, 75:(7), pp. 549-564. 
ZOLNAY J. (2012): Forrásínség - Vállalkozási kényszer és fizetésképtelenség Tiszabőn. In: Beszélö, 7:(6)

ZOMBORI GY. (1997): A szociálpolitika alapfogalmai. Budapest, Hilschler Rezső Szociálpolitikai Egyesület

Zsom B. (2015): A jóllét mérése hátrányos helyzetü régiókban. In: Területi Statisztika, 55:(3), pp. 273-287.

\section{Internetes források}

Csoba J. - Dénes A. - Kiss M. - Koós B. Á. - RÁcz K. - Schwartz Gy. (2008): Alkalmazkodási stratégiák a vidék gazdaságában. Munkabeszámoló. OTKA. http://real.mtak.hu/1883/1/48886_ZJ1.pdf

Utolsó letöltés: 2018. május 17.

EMMI - EMBERI ERŐFORRÁSOK MINISZTÉRIUMA (2017): Tájékoztató a szociális ellátásokról. Budapest, EMMI Központi Ügyfélszolgálati Iroda https://csaladitudakozo.kormany.hu/download/f/54/c1000/HSzoc $\% 20$ füzet $\% 20201$ $\underline{\text { 7.pdf }}$

Utolsó letöltés: 2018. augusztus 26.

EURÓPAi BIZOTTSÁG (2010): „Európa 2020” az intelligens, fenntartható és inkluzív kezdeményezések stratégiája http://ec.europa.eu/eu2020/pdf/1_HU_ACT_part1_v1.pdf

Utolsó letöltés: 2018. augusztus 26.

EuROSTAT (2016): Tertiary Education Statistics - Statistics Explained.

https://ec.europa.eu/eurostat/statistics-

explained/index.php/Tertiary_education_statistics

Utolsó letöltés: 2018. augusztus 26.

Eurostat (2017): Newsrelease, 52/2017 - $30 \quad$ March 2017 http://ec.europa.eu/eurostat/documents/2995521/7962764/1-30032017-AP_EN.pdf/4e9c09e5-c743-41a5-afc8-eb4aa89913f6

Utolsó letöltés: 2018. augusztus 25.

G. FeKete Éva - PÉTER Zsolt - Siposné NÁNdori EszTER - LiptÁk KATAlin - HegYiKÉRI ÁGNES (2013): Területi politikák és stratégiák. Miskolci Egyetem Gazdaságtudományi Kar, TÁMOP 4.1.2.A/1-11/1-2011-0046 - ME GTK és MÜTF 
Nemzetközi gazdálkodás szakadnak angol és magyar nyelvű digitális tananyag fejlesztése.

http://www.tankonyvtar.hu/hu/tartalom/tamop412A/2011-

0046_03_terpol/tananyag/07_1.html

Utolsó letöltés: 2019. február 10.

IFJÚSÁGI GARANCIA AKCIÓTERV (2014)

http://ngmszakmaiteruletek.kormany.hu/ifjusagi-garancia-akcioterv

Utolsó letöltés: 2018. szeptember 5.

JNSZM - JÁSZ-NAGYKUN-SZOLNOK MEgYe GAZDASÁgI ÉS FOGLALKOZTATÁSI

FEJLESZTÉSI STRATÉGIÁJA (2017)

http://www.jnszm.hu/wp-content/uploads/sites/4/2019/07/Megyei-strategia-

tervezet-2017.02.17.-honlapra2.0.pdf

Utolsó letöltés: 2019. augusztus 20.

KSH - KÖZPONTI StatiszTiKai Hivatal (2016A.): Gyorstájékoztató Munkanélküliség, 2016. Július-Szeptember. 2016. Október 27.

http://www.ksh.hu/docs/hun/xftp/gyor/mun/mun1609.html

Utolsó letöltés: 2018. augusztus 25.

KSH - KÖZPONTI STATISZTIKAI HIVATAL (2016C.): A komplex programmal fejlesztendő járások jellemzői, 2014

http://www.ksh.hu/docs/hun/xftp/idoszaki/pdf/kompjar14.pdf

Utolsó letöltés: 2018. augusztus 25.

LECHNERKÖZPONT.HU - Tiszabő

http://webmap.lechnerkozpont.hu/webappbuilder/apps/foldgomb1708/

Utolsó letöltés: 2018. augusztus 25.

MENETRENDEK.HU - Tiszabőtől és irányába történő menetrendek és menetidők

https://menetrendek.hu

Utolsó letöltés: 2018. augusztus 13.

MOLNÁR-RÉVÉSZ E. (2011): Alig lehet ráismerni az iskolára Tiszabőn

https://www.szoljon.hu/jasz-nagykun-szolnok/kozelet-jasz-nagykun-szolnok/alig$\underline{\text { lehet-raismerni-az-iskolara-tiszabon-729711/ }}$

Utolsó letöltés: 2018. szeptember 5.

NÉPESSÉG.COM - Tiszabő

http://nepesseg.com/jasz-nagykun-szolnok/tiszabo

Utolsó letöltés: 2018. augusztus 25. 
NFSZ - NeMZeti Foglalkoztatási SzolgÁlat (2014): A Nemzeti Foglalkoztatási Szolgálat fontosabb adatai, 2014. szeptember

www.nfsz.gov.hu/resource.aspx?ResourceID=afsz_havi_reszletes_adatok_201409

Utolsó letöltés: 2018. augusztus 25.

NFSZ - NEMZETI FoGLALKOZTATÁSI SzOLGÁlAT (2016): A nyilvántartott álláskeresők száma a tartózkodási helyük szerint, településenként (2016. 09. 20-i állapot szerint)

https://nfsz.munka.hu/Lapok/full_afsz_kozos_statisztika/full_AFSZ_Telepulessor os_munkanelkulisegi_adatok/full_afsz_stat_telepules_adatok_2016/content/afsz_ stat_telepules_adatok_2016_9.pdf

Utolsó letöltés: 2018. május 21.

NFSZ - NemZeti Foglalkoztatási Szolgálat (2018): Az NFSZ adatainak összefoglaló táblázata, 2018. június

https://nfsz.munka.hu/Lapok/full_afsz_kozos_statisztika/full_afsz_az_afsz_nyilv antartasok_fontosabb_adatai/content/nfsz_havi_reszletes_adatok_2018_06.pdf Utolsó letöltés: 2018. augusztus 13.

Policy AgENDA (2017): Létminimum 2016-ban Magyarországon http://www.policyagenda.hu/uploads/files/Létminimum\%202016.pdf

Utolsó letöltés: 2017. December 15.

SzEGÖ J. (2010): Sziget a Tisza partján - Tiszabői riport

http://www.litera.hu/hirek/sziget-a-tisza-partjan-tiszaboi-riport

Utolsó letöltés: 2018. augusztus 25.

SZOLNOK HELYI JÁRATAINAK DÍJTÉTELEI - KÖZÉPKELET-MAGYARORSZÁGI KÖZLEKEDÉSI

KÖZPONT ZRT.

https://www.kmkk.hu/19-varosok-helyi-jarati-dijtetelei

Utolsó letöltés: 2018. december 16.

VG.HU - Száznyolcvanmilliós fejlesztés Szolnokon

https://www.vg.hu/gazdasag/szaznyolcvanmillios-varosfejlesztes-szolnokon$\underline{738853 /}$

Utolsó letöltés: 2018. augusztus 27.

VOLÁNBUSZ DÍJSZABÁS

https://www.volanbusz.hu/hu/utazasi-

informaciok/jegyvasarlas/dijszabas/dijszabas\#mozTocId742423

Utolsó letöltés: 2018. június 21. 


\section{Egyéb források}

BFH EuRÓPA (2017): Szolnok Megyei Jogú Város foglalkoztatási helyzetelemzése. Szolnoki Foglalkoztatási Paktum- Együttmüködés Szolnok gazdaságának fejlesztéséért és a szolnoki munkahelyekért. TOP-6.8.2-15-SL1-2016-00001 projekt

EUR-LEX (2008) 2008.08.09. 2. Cikk 18. pont Európai Közösség Bizottsága 800/2008/EK rendelet

JNSZML - JÁSZ-NAGYKUN-SZOLNOK MEGYEI LEVÉLTÁR (1965)：XXIII-747-c-5/1965

MAGYAR KÖZLÖNY (2011): 2011/85, 2011. Július 19 - A szociális igazgatásról és a szociális ellátásokról szóló 1993. évi III. törvény módosítása 21. §

MAgYAR KÖZlÖNY (2014A): 2014/161. szám A Kormány 290/2014. (XI. 26.) Korm. rendelete a kedvezményezett járások besorolásáról

MAGYAR KÖZLÖNY (2014B): 2014/189. szám, 2014. december 31. A Kormány 376/2014. (XII. 31.) Korm. rendelete a közfoglalkoztatási bér és a közfoglalkoztatási garantált bér megállapításáról szóló170/2011. (VIII. 24.) Korm. rendelet, továbbá a pénzbeli és természetbeni szociális ellátások igénylésének és megállapításának, valamint folyósításának részletes szabályairól szóló 63/2006. (III. 27.) Korm. rendeletet módosításáról

MAGYAR KÖZLÖNY (2017): 2017/40. szám. 2017. március 20. 1139/2017. (III. 20.) Korm. határozat - Az egyes munkaerőpiaci intézkedésekről

MAGYAR KÖZlÖNY, 2016/108. szám 1391/2016. (VII. 21.) Korm. rendelet Tiszabő és Tiszabura települések helyzetének rendezéséről

SZMJVÖ - SZOLNOK MEGYEI JOGÚ VÁROS ÖNKORMÁNYZAT (2011): „Tanulás és közösségfejlesztés” - Komplex humán szolgáltatás hozzáférés biztosítása Szolnokon c. program Közösségi Beavatkozási Terve a TÁMOP-5.3.6-11/1 pályázathoz.

SZMJVÖ - SZOLNOK MEGYEI JOGÚ VÁROS ÖNKORMÁNYZATA (2006) Előterjesztés a Roma Integrációs Programjának felülvizsgálatára és aktualizálására, 2006.

SZMJVÖ - SZOLNOK MEgYei Jogú VÁRos ÖnKormÁnYZATA (2013): Helyi Esélyegyenlőségi Program, 2013

SZMJVÖ - SZOLNOK MEgYeI JOGÚ VÁRos ÖNKORMÁNYZATA (2014A)

Antiszegregációs Program In: SZMJV Integrált Városfejlesztési Stratégia, Egyeztetési Dokumentáció, VÁTERV95, 2014 
SZMJVÖ - SZOLnOK MegYeI Jogú VÁRos ÖnkormÁnYZATA (2014B): Beszámoló Szolnok Megyei Jogú Város Önkormányzatának Integrációs Programjáról, különös tekintettel a hátrányos helyzetű rétegek életesélyeinek javításáról, valamint az IVS Anti-szegregációs Terv 2014. évi intézkedéseinek eredményeiről SZVF - SzOLNOKI VÁROSFEJlESZTŐ NONPROFIT ZRT. (2017): Komplex Telep II. Törteli út környéki szegregátum társadalmi felzárkózást célzó fejlesztése c. TOP6.9.1-15-SL1-2016-00001 azonosító számú projekt - Projekt-előkészítő tanulmány

TKKI - TÜRR ISTVÁN KÉPZÖ ÉS KUTATÓ INTÉZET (2011): Roma telepeken élők lakhatási és szociális integrációs programja - A szolnoki modellprogram, Debrecen

VÁRos-TEAMPANNON (2012): Jász-Nagykun-Szolnok Megyei Területfejlesztési Koncepció. Társadalmi, gazdasági, környezeti helyzetelemzés. Helyzetfeltárás, egyeztetési anyag. 


\section{Köszönetnyilvánítás}

A dolgozat és a kapcsolódó kutatás módszertani, valamint elméleti hátteréhez nyújtott szakmai javaslatokért szeretnék kiemelt köszönetet mondani témavezetőmnek, Dr. Boros Lajosnak. Hálásan köszönöm a konzultációk és szakmai beszélgetéseink során mind a témám elméleti keretéhez kapcsolódó hazai és nemzetközi irodalomhoz kötődő, mind a definíciók és elméletek adaptálásában nyújtott javaslatokat, mind pedig a kutatás empirikus folyamataihoz kapcsolódó adatfelvételben és az adatok feldolgozásában, elemzésében nyújtott észrevételeket és a dolgozat elkészítésében való folyamatos segítséget, támogatást.

Továbbá az adatfelvételben és az adatrögzítésben nyújtott fáradhatatlan munkájáért köszönet illeti Ale Évát, aki a tiszabői és a szolnoki háztartásokban végzett kérdőívezés és az adatok adatbázisba rendezése során is nélkülözhetetlen segítséget nyújtott a kutatás megvalósulásához.

Köszönöm a segítséget Mitrik Dórának, aki fantasztikus képeivel lehetővé tette a kutatáshoz kapcsolódó eredmények képi világának ábrázolását, és elkészítette a „Maximum létminimum - Tiszabő” című publikációhoz kapcsolódó fotókat.

Köszönettel tartozom Dr. Dudás Gábornak, aki a térképek szerkesztésében nyújtott segítségével hozzájárult a mintaterületek vizuális megjelenítéséhez és a kutatás eredményeinek térbeli szemléltetéséhez.

Végül köszönöm mindazoknak a tiszabői és szolnoki háztartások segítségét, akik megtiszteltek bizalmukkal és értékes információikkal lehetővé tették doktori kutatásom megvalósulását. Továbbá köszönet azoknak a szociális szakembereknek, akik hasznos ismeretekkel és információkkal láttak el a kutatásom célcsoportjával kapcsolatban, illetve javaslataikkal megkönnyítették a családok, háztartások elérését. 


\section{Összefoglalás}

A rendszerváltás után kialakult munkanélküliség a periférikus területeken a hazai átlagnál jóval nagyobb mértékben éreztette hatását. Ennek okai között szerepel, hogy a megszünt, vagy leépített ágazatokban korábban alacsony iskolai végzettséggel is lehetőség nyílt a munkavégzésre, de a piacgazdaság körülményei között nem volt lehetőségük az elhelyezkedésre. Ennek eredményeként ezek az emberek inaktivitásba menekültek, amelyre az 1990-es évek állandó jövedelmet biztosító szociál- és foglalkoztatáspolitikai eszközei is lehetőséget biztosítottak. Ennek hatására viszont e családok bevételei jelentősen csökkentek és drasztikusan megnőtt a szegénység, amely miatt kialakult körükben a szegénység kultúrájának érték- és normarendszere. Ez egyrészt segít túlélni a mindennapokat, de egyben megakadályozza a közösségeket, hogy kilépjenek a szegénység körülményeiből, amelyet generációkon át továbbörökítenek és újratermelik a mélyszegénység viszonyainak túlélésére berendezkedett életmódot. A 2010-es években történt szociál- és foglalkoztatáspolitikai szemléletváltásának eredményeként a jelenlegi rendszer már egy felajánlott munkalehetőség - ami a legtöbb esetben közfoglalkoztatás - kötelező elfogadásához köti a támogatások kifizetését, amely komoly szerepet játszik a hátrányos helyzetü emberek megélhetésében. A közmunkaprogram deklarált célja, hogy minél több embert vezessenek vissza az elsődleges munkaerőpiac világába. Viszont idővel világossá vált, hogy a közmunka csökkenti a nyílt munkaerőpiacon való elhelyezkedés esélyeit és mérsékli a munkakeresési hajlandóságot.

A disszertációhoz kapcsolódó kutatás célja volt definiálni azok a tényezőket, amelyek a leginkább hatással vannak a periférikus területeken élők munkahelymegtartó képességére, illetve meghatározni ezen faktorok között megmutatkozó területi szinten megjelenő különbségeket a vidéki jellegü- és a centrumhoz közeli periféria relációjában. Emellett további cél volt megállapítani a periférikus térségekre jellemző szegénység kultúrájához kapcsolódó sajátos és közös jellemvonásokat.

A kérdések megválaszolására olyan, a regionális és megyei településhierarchia két különböző szintjén megjelenő területeket, települést és településrészt kerestem, ahol a területi- és társadalmi hátrányok halmozottan vannak jelen. Így a periférikus területek munkaerő-piaci jellegzetességeit és az ott élő hátrányos helyzetű emberek elhelyezkedési lehetőségeit egyrészt - a vidéki periférián található - Tiszabő község példáján mutatom be, amely amellett, hogy a Közép-Tisza vidékén kialakult belső periférián helyezkedik el, a 2010-es években több alkalommal (legutóbb 2014-ben) Magyarország 
legszegényebb települése lett. A centrumhoz közeli, városi perifériát reprezentáló mintaterületnek a szolnoki Törteli úti szegregátumot választottam, amely azonfelül, hogy Szolnok városhatárán belül, tehát regionális és megyei szinten központi helyen található, a település szempontjából mégis periférikus területen helyezkedik el, és rendelkezik minden olyan tulajdonsággal, amely a periférikus térségeket jellemzi.

Az összesen 119 háztartás és szociális szakemberek bevonásával, kérdőívek, interjúk és résztvevő megfigyelés segítségével végzett terepkutatás eredményei alapján elmondható, hogy a periférikus területeken élő hátrányos helyzetüek átlagos életkora jóval a magyar társadalom átlagéletkora alatt van, amelynek okai között szerepel a korai gyermekvállalás, az egészségügyi szolgáltatások hiánya, a szenvedélybetegségek jelenléte, vagy éppen a lakókörnyezet egészségkárosító hatása. Az alacsony átlagéletkor egyben fiatalodó társadalmat is jelez, amely együtt jár a gyermekkorúak magas arányával. A kiemelkedően nagy számú gyermekkorban lévők miatt a periférikus területeken száz aktív korúra jutó inaktív személyek aránya meghaladja a hazai átlagot.

$\mathrm{Az}$ eredmények egyértelműen jelzik, hogy a vidéki periférián lényegesen magasabb szintű iskolai végzettséggel rendelkeznek az emberek, mint a városi szegregátumban, mindemellett arányaiban többen szereztek szakmai képesítést is. Emiatt természetesen a vidéki, belső periférián található Tiszabőn élő emberek elsődleges munkaerőpiacon való elhelyezkedési esélyei kedvezőbbek, amely megmutatkozik az önálló jövedelemmel rendelkezők háztartáson belüli magasabb arányában és a (primerés másodlagos) munkaerő-piaci aktivitás szintjében is. E faktorok pedig hatással vannak az egy főre jutó jövedelemre, amely alapján a vidéki periférián élők egy főre jutó átlagos jövedelme minimálisan, de a szegénységi küszöb objektív határa felett található, míg a centrumhoz közeli periférikus területek lakói - számított - mélyszegénységben élnek. Ellenben minden más, szegénységet mérő mutató - EU mélyszegénység számítása; hazai létminimum kalkuláció; élelmiszerfogyasztás normatív értéke alapján mért létminimum - szerint mindkét periférikus terület lakói jelentősen a számszerüsített szegénységi érték határa alatt élnek.

Míg a rurális jellegü periférikus területek inaktív csoportjai a megélhetésüket elsősorban a közmunkaprogramra alapozzák, addig a városi periférián élő inaktívak főképpen alkalmi, napszámos munkákból próbálnak megélni. A centrumhoz közeli periférián élő aktív korúak korábban végeztek először kereső tevékenységet, amely a vizsgált területeken élők iskolai végzettségbeli különbségeiben is megjelenik, hiszen a rurális terület hátrányos helyzetü lakói hosszabban folytatott tanulmányaik miatt később tudnak kereső tevékenységet végezni. Az iskolai végzettségnek adott térségen belül is 
meghatározó szerepe van: a rurális jellegü és a városi periférikus területeken élők elsődleges munkaerőpiacon aktív és inaktív csoportok között e jellemzőben lehet a legjelentősebb különbséget kimutatni. Az iskolai végzettséggel szoros összefüggést mutató munkaerő-piaci lehetőségek különbségei pedig a fizetések mértékében is megjelennek. Az elsődleges munkaerö-piaci pozíció jövedelemre gyakorolt hatása területi szinten minimális, viszont adott településen, településrészen belül közel kétszeres különbséget lehet kimutatni az egy före jutó jövedelmek tekintetében egy elsődleges és egy másodlagos munkaerö-piaci munkakör között. Ennek hatására a periférikus területeken élő, elsődleges munkaerőpiacon dolgozók háztartásainak életszínvonala megközelíti a létminimum szintjét, a nyílt munkaeröpiacon inaktívak háztartásaiban élők viszont a szegénységi küszöböt sem érik el. Tehát az iskolai végzettség emelkedése és a szakmai képesítés megléte kedvezően hat a periférikus területeken élők elsődleges munkaerő-piaci integrációjára és háztartásuk bevételeinek mértékére. Emellett a munkaerő-piaci szerepvállalásra pozitívan ható tényezők közül kiemelkedik a minél fiatalabb korban lévő első munkavállalás is. Az elsődleges munkaerő-piaci aktivitás aránya a rurális periférián élők között némileg magasabb, amelyhez - a városi szegregátumban élőkhöz képest - magasabb jövedelem is kapcsolódik.

A periférikus területeken élők számára a munkaköri feladatok elsajátítása, teljesítése és a határidők tartása sem okozott gondot. Az eredmények alapján elmondható, hogy a szegénység kultúráját elsajátított csoportokra jellemző, más környezetbe történő nehéz beilleszkedés nem jellemzi a periférikus területeken élő hátrányos helyzetü embereket. Tehát a szegénység kultúrájának attribútumai - a munkahelyi környezethez és időkerethez alkalmazkodás nehézsége, rövid távra tervezés - nem akadályozzák a periférikus területeken élő hátrányos helyzetüek hosszú távú munkahelymegtartását. A munkaképes korú emberek mindkét periférián nehézségek nélkül szocializálódtak jelenlegi, vagy korábbi munkahelyükön és jellemzően több évig meg tudták tartani pozíciójukat. Viszont a munkahelymegtartó képesség összefügg az aktuális munkaerőpiaci státusszal, hiszen a nyílt munkaeröpiacon dolgozók között nagyobb arányban figyelhető meg hosszú távú munkahelymegtartás. Mivel a munkaerő-piaci szerepvállalás összefüggésben van az iskolai végzettséggel, kijelenthető, hogy a képzettség szintjének emelkedésével párhuzamosan növekszik egy adott munkahelyen eltöltött idő, vagyis javul a munkahelymegtartás képessége. A területi különbségeket figyelembe véve megállapítható, hogy az egy munkahelyen eltöltött leghosszabb időtartam alapján a vidéki periférián élők közel háromszor hatékonyabb munkahelymegtartó képességgel rendelkeznek, mint a városi szegregátumban élő hátrányos helyzetüek. Ennek ellenére a 
szegénység kultúrája mindkét vizsgálati térségben jelen van, de elsősorban az urbánus periférián élők mindennapi életére van hatással, akiknek családi életét mélyen áthatja a szegénykultúra érték- és normarendszere.

A kutatási eredmények megmutatták, hogy a periférikus területekre jellemző földrajzi sajátosságok és a közösségi közlekedés infrastrukturális nehézségei negatív hatással vannak az ott élő hátrányos helyzetűek nyílt munkaerő-piaci megjelenésére. Ezek a körülmények elsősorban az inaktívak számára okoznak problémát a munkaügyi központ, vagyis a kormányhivatal foglalkoztatási osztályának elérése során. Ennek ellenére mind a vidéki, mind pedig a városi perifériák lakói elsősorban a kormányhivataltól várnak segítséget munkaerö-piaci helyzetükre. Viszont a közfoglalkoztatási szerződés folyamatos megújításával a rurális perifériához tartozó munkaügyi kirendeltség csak konzerválja a periférikus területeken élők munkaerö-piaci helyzetét, amelyet az elsődleges munkaerö-piaci szempontból inaktívak alacsony munkakeresési motivációja tovább stabilizál.

A kutatás során világossá vált a periférikus területeken élők mindennapi életét befolyásoló és munkaerő-piaci szerepvállalásukra is kedvezőtlenül ható területi stigma szerepe, amely mindkét periférikus terület esetében az elsődleges munkaerőpiachoz kapcsolódó foglalkoztatási övezetre terjed ki. A területi stigma jelentősebb mértékben nehezíti a hátrányos helyzetűek munkavállalását, mint a származás alapján történő megkülönböztetés.

A periférikus területeken élő hátrányos helyzetűek a földrajzi elszigeteltségéből, másrészt jellemzően alacsony iskolai végzettségükből adódó jelentős információhiány és szervezőképességük alacsony szintje miatt nem, vagy csak nehezen képesek önállóan megszervezni elhelyezkedésüket a nyílt munkaerőpiacon. Az elsődleges és másodlagos munkaerő-piaci pozíciókhoz jutásban a vidéki periférián élők esetében legfontosabb szerepe a kapcsolati tőkének van, míg a városi periférián élők számára a munkaügyi központ jelenti a legnagyobb segítséget az elhelyezkedésben.

A periférián élők hátrányos helyzetének tartós fennmaradását a térséget érintő szegregálódási és marginalizációs folyamatok mellett a szegénység kultúrájának mélyen beágyazódott értékei, valamint olyan külső tényezők is - önkormányzat, illetve környéken élő családok - konzerválják, amelyek érdeke a célcsoport - iskolai szint, pénzügyi körülmény és információs ellátottságbeli - helyzetének fenntartása.

Az eredmények szerint területi relációban a vidéki periférikus térségben sokkal jelentősebb foglalkoztatási szerepet tölt be a közmunkaprogram, ahol az inaktívak közül szinte mindenkit az önkormányzat foglalkoztat. A városi periférián élők 
közfoglalkoztatásban betöltött szerepvállalása a tiszabőiek arányának kevesebb, mint felét teszi ki. Az eredmény nem véletlen, hiszen a vidéki periférikus területeken helyben elérhető munkahelyek hiánya miatt folyamatos igény van a programban való részvételre. Ezzel összhangban a közfoglalkoztatásban végzett munkájukkal a vidéki periférián élők elégedettebbek. A közmunkaprogram egyik pozitívuma, hogy közel minden másodlagos munkaerőpiacon elhelyezkedő munkavállaló tapasztalta háztartásuk anyagi helyzetének javulását, amely viszont nem vonja egyértelmủen magával a szegénység kultúrához kapcsolódó normák megváltoztatását. Ezt a közmunkaprogramban tapasztalható - nyílt munkaerő-piaci szereplőkhöz viszonyított - alacsonyabb teljesítménybeli elvárások sem segítik. Viszont a közfoglalkoztatás két alapvető követelménye, a pontos érkezés és a precíz munkavégzés hozzájárul a hátrányos helyzetủek időkerethez való igazodásának, szabályokhoz való alkalmazkodásának, és az elvégzett munkájuk minőségének fejlesztéséhez. Emellett a közmunkaprogram a közösségben végezhető pozitív munkatapasztalat, és az elsajátított munkafolyamatok eredményeként kedvezően hat a periférikus területeken élő közfoglalkoztatottak munkahelyi integrációjára. A megszerzett munkarutin és munkarend kialakításának köszönhetően viszont hosszú távon csökkenhet a szegénység kultúrájának szerepe. Így a közmunkaprogram munkaszocializációs célja valójában meg is valósulhatna, ha nem érvényesülne a közfoglalkoztatás a résztvevők munkakeresésére kifejtett kontraproduktív hatása. Ugyanis a munkaképes korú inaktív hátrányos helyzetüek többsége nem keres nyílt munkaerö-piaci állást, hiszen a rurális területeken a közmunkaprogram által kínált lehetőségek miatt jövőjüket is a másodlagos munkaerő-piaci jelenlétre alapozzák. Ezért a közfoglalkoztatásban való részvétel következtében kialakuló munkakeresési motivációcsökkenés redukálja a nyílt munkaerő-piaci integráció esélyét. Következésként elmondható, hogy a közmunkaprogram az eredetileg megfogalmazott célját - amely szerint a munkaszocializációt elősegítő tevékenységek hatására visszavezeti a résztvevőket az elsődleges munkaerőpiacra - nem tudja elérni a periférikus területeken. Ennek ellenére a közmunkaprogram nélkülözhetetlen eszköz a periférikus területeken élő emberek mindennapi megélhetésének és szociális helyzetének fenntartásához. 


\section{Summary}

The unemployment surge that followed the regime change in Hungary had a much greater impact on the periphery compared to the national average.

In the socialist state-controlled economy, full employment meant that even underqualified people were obliged to get jobs at state-owned companies. However, in the conditions of the new market economy, most of these companies closed and their workers found themselves unemployed and they were not able to find other employment.

As a result, these people fled to inactivity and although the social and employment policy instruments of the 1990s provided them a steady income, the earnings of these families decreased considerably and poverty increased dramatically. This led to the emergence of norms and values of the poverty culture among them. On the one hand, this helps them to survive everyday life, but on the other hand, simultaneously prevent them from escaping from the circumstances of poverty. Poor people pass on the values of culture of poverty through generations and reproduce the lifestyle designed to survive the conditions of extreme poverty. The change of attitude of social and employment policy in the 2010s led to the current system, which makes the payments of benefits conditional upon the acceptance of an offered - in most of cases public works programme related - job. The public works employment plays a major role in the livelihood of underprivileged people and its declared aim is to lead as many people back to the primary labour market as possible. However, over time, it has become clear that the public works programme reduces the chance of employment in the primary labour market and weakens the willingness to find work.

The aim of the research related to the dissertation was to define the factors that have the greatest impact on the job keeping skills of the people living in peripheral areas, and to determine the regional differences between the rural and central periphery in the relation of these factors. In addition, the purpose was to identify the specific and common characteristics of culture of poverty in peripheral areas. To answer the questions, I was looking for areas and settlements appearing at two different levels of the settlement hierarchy, where the territorial and social disadvantages are cumulative. Thus, I present the labour market characteristics of the peripheral areas and the employment opportunities of underprivileged people living there based on the example of Tiszabö, which is the sample of the rural peripheral area. The village is located in the inner 
periphery of Central Tisza Region and it became the poorest settlement in Hungary in the 2010s several times, most recently in 2014.

I chose the segregated area of Törteli Road in Szolnok as a sample of periphery near the centre, which is located within the city of Szolnok, therefore it is centrally located at regional and county level, nevertheless, it is situated at a peripheral area of the city. The area has all the features that characterize the peripheral territories.

The field research involved 119 households and professionals working in the social sector using the methods of questionnaires, interviews and participant observation.

According to the results, the average age of underprivileged people living in peripheral areas is well below the average age of Hungarian society, which is caused by early childbearing, lack of health services, the presence of addictive or the harmful effect of the living environment on health. Low average age indicates a rejuvenating society, which is associated with a high proportion of children. Due to the exceptionally high number of children, the proportion of inactive persons per hundred people in active age is higher in peripheral areas than the national average.

The results clearly indicate that people living in the rural periphery have much higher level of education than people living in the urban segregated area. In addition, proportionally more people obtained professional qualifications in rural periphery. Because of this, people living in Tiszabö located in the inner periphery have a better chance of finding employment in the primary labour market, which is reflected in the higher proportion of employed persons within the household and level of secondary and primary labour market activity.

These factors have an impact on per capita income; specifically, the average income of those living in rural periphery is only to a small degree, but above the objective of poverty threshold, while the residents of peripheral area near to the centre live in extreme poverty. All other poverty-related indicators - EU poverty line, domestic subsistence level calculation and subsistence level measured by the normative value of food consumption - the inhabitants of both peripheral areas are living significantly below the quantified poverty value.

The inactive groups of rural peripheral area plan their subsistence in the public works programme, the inactive people living in urban peripheral area try to maintain themselves based on casual day labour. People in active age living in periphery near to the centre started working in younger age, which appears in the differences of educational attainment, since the underprivileged residents of rural area could get a job later, because of their longer studies. 
Educational attainment has an important role in connection with the primary labour market. This trait is most significant difference between the active and inactive groups of the primary labour market. The differences in labour market opportunities - which are closely linked to educational attainment - are also reflected in salary levels.

The impact of the primary labour market position on income at territorial level is minimal, however, within the investigated settlements, the difference in terms of per capita income is almost twofold between a primary and a secondary labour market position. Thus, the average living standard of households living in peripheral areas and working in the primary labour market is close to the minimum subsistence level, but the members of the inactive households live well below the poverty line.

Therefore, the increase in educational attainment and an obtained professional qualification have a positive effect on the primary labour market integration of the people living in peripheral areas and the income of their households. In addition, the factor that positively influences the labour market participation is the first job at young age.

The rate of primary labour market activity among the people living in rural periphery is slightly higher, and they also have higher incomes than those living in the urban segregated area. There was no problem for the people living in peripheral areas to learn and complete the job duties and meet deadlines. According to the results, the difficult of integration into new environment - which is general among groups socialized based on the values of culture of poverty - is not a characteristic of underprivileged people living in peripheral areas. So, the attributes of culture of poverty - difficulties of adapting to workplace environment and schedules as well as short term planning - do not hinder the long-term employment of underprivileged people living in peripheral areas. The working age population in both peripheral areas were able to socialize without difficulty in their current or former workplace and were typically able to keep their position for several years. However, the job keeping skill is related to the current labour market status, as long-term job retention is more prevalent among workers in primary labour market. As labour market participation is linked to educational attainment, it can be stated, that as the level of education increases, the amount of time spent in a workplace increases too, thus the ability to keep a job improves. Taking into account the territorial differences, it can be stated, based on the variable of keeping a job for the longest period, those living in rural periphery have nearly three times more effective job retention than those living in urban segregated area. 
Although, the culture of poverty is present in both areas, it primarily affects the everyday lives of those living in urban periphery, whose family life is deeply steeped by the values and norms of the poverty culture.

The research results have shown, that the geographical characteristics of peripheral areas and the difficulties of public transport infrastructure have a negative impact on the primary labour market participation of underprivileged people. These circumstances are the most problematic for inactive people when trying to access the employment centre. Nonetheless, residents of both rural and urban peripheries are primarily seeking help from the employment centre for their labour market situation. However, with the continuous renewal of the public works employment contract, the employment office linked to the rural peripheral area only conserves the labour market situation of underprivileged people, which gets further stabilized by the low job search motivation of inactive people. During the research, the role of territorial stigma has become clear, which unfavourably affects everyday lives and labour market participation of people living in peripheral areas. In both peripheral areas, the territorial stigma covers the employment zone related to the primary labour market. The territorial stigma more significantly complicates the employment of underprivileged people, than the discrimination based on ethnic origin. Disadvantaged people living in peripheral areas are unable to organize their employment in the primary labour market due to their geographical isolation and low educational attainment and low level of organizational capacity.

In the case of people living in rural periphery, social capital plays the most important role in getting primary, or secondary labour market job, while the employment centre provides the greatest help to those living in urban periphery.

In addition to the segregation and marginalization processes affecting the region, the deeply embedded values of poverty culture also preserve the long-term persistence of the situations of those living in periphery. Besides these factors, external actors - local government, and families living in nearby areas - conserve the situation, whose interest is to maintain the current - education attainment level, information supply - situation of underprivileged people.

According to the results, the public works programme plays a more important role in employment in the rural periphery, where almost all the inactive people are employed by the local government. On the other hand, the proportion of public works employees among the people living in the urban periphery are less than half in Tiszabö. The result is not a coincidence. Since there is a continuing need in rural periphery to participate in 
the programme due to the lack of locally available jobs in rural peripheral areas. In line with this, people living in rural periphery are more satisfied with their job in public work programme.

One of the positive factors of the public works programme is that nearly every worker on the secondary labour market has experienced an improvement in the financial situation of their household. However, it does not clearly imply a change in the norms of poverty culture.

The comparatively lower expectations of the public works programme do not help eliminating the culture of poverty. On the other hand, the two basic requirements of the public works programme, on-time arrival and precise work, contribute to improving the adaptation to schedule and rules, as well as the quality of work done by underprivileged people. The public works programme has a positive effect on the workplace integration through the positive work experiences in community and learned workflows. The acquired work routine and work schedules can reduce the role of poverty culture. Thus, the work socialization goal of the public works programme could actually be achieved, if the counterproductive effect of the programme would not apply on the workers' job search motivation. Since, the majority of inactive underprivileged people of working age are not looking for primary labour market jobs, because people living in rural areas base their future on the secondary labour market in jobs offered by public works programme. Therefore, the reduction in job search motivation caused by from participation in public works programme reduces the chances of primary labour market integration.

Consequently, the public works programme is not able to achieve its original purpose in peripheral areas, which is to lead participants back to the primary labour market as a result of work-socialization activities.

Nonetheless, the public works programme is an essential tool for maintaining the daily living and social status of people living in peripheral areas. 


\section{Mellékletek}

Melléklet 1. - A magyarországi telepfelszámolás és a CS-lakások építésének folyamata

A városi telepek felszámolásának egyik magyarázataként szolgált, hogy a cigányságot nem tekintették nemzetiségnek, ezért kisebbségüket asszimilálni kellett, vagyis a nem cigány lakosság között szétszórni. Emellett a ,járványok és a bünözés melegágyának" bélyegzett szegregátumok megszüntetését tervezték. Természetesen a másik ok a nyomortelepekben manifesztálódó létminimum alatti élet jeleinek a nyugati sajtóügynökségek elől való eltüntetése volt. A valós probléma, hogy a cigányság jelentős része kifejezetten egészségtelen körülmények között élt, szinte teljesen figyelmen kívül maradt (KEMÉNY et al. 1976 idézi: TóTH et al. 2012). A rendelet egyrészt azért is volt meglepő, mert a pártállam 1957-ben megszüntette az ingyenes házhelyjuttatást, a cigányok pedig nem csak a földosztásból, hanem a tanácsi lakások kiutalásából is kimaradtak. 1963-ban már a párt felső vezetése is belátta, hogy az ingyenes házhelyjuttatás megszüntetése és a cigánytelepeken élő lakosság csak minimális arányának hitelképessége miatt a telepfelszámolás teljes kudarc lett. Emiatt a Politikai Bizottság utasítására az Építésügyi Minisztérium és a Pénzügyminisztérium tervezetet készített a cigány lakosság részére, amely „egyszerübb házak” kedvezményes hitelfelvétellel való építését és azok ,egyszerübb bútorokkal” való berendezését szolgálta (TóTH et al. 2012). Ennek következtében viszont megkezdődött a népesség eláramlása a falvakból a városok felé. 1964-ben már a Magyar Forradalmi Munkás Paraszt Kormány elnöke adta ki azt a határozatot, amely a szociális követelményeknek nem megfelelő telepek felszámolásáról döntött. Ennek értelmében az érintett lakásokat egyrészt önerőből, másrészt állami támogatással a települések építési övezetében szétszórtan kellett építeni, családi házak formájában, amely a cigány lakosság társadalomba való beilleszkedését igyekezett szolgálni. Így megkezdődött a „CS”, vagyis „,csökkentett értékü" lakásprogram, amely 1965-től a szocializmus összeomlásáig kifejezetten a cigány lakosságot célozta meg. Viszont a helyi tanácsok többnyire megakadályozták a CS-lakások településen belüli szétszórt építését, így ezeket a házakat egy tömbben, újabb szegregátumokat létrehozva építették (TÓTH et al. 2012). Az elvándorlási folyamatot az 1971-es Országos Településhálózat-fejlesztési Koncepció tovább erősítette a fejlesztési források a városokba - elsősorban a megyeszékhelyekre (KOVÁCS 1999) - történő koncentrálásával. A koncepció nem támogatta a falvak fejlesztését (BAJMÓCY et al. 
2007), ezért a községek helyzete jobb esetben stagnált. Számos település körülményei romlottak az ipar elszívó hatására, a kedvezőtlen mezőgazdasági adottság, valamint a nem megfelelő közlekedés-földrajzi helyzet és az infrastruktúra elmaradottságának következtében (KÖSZEGFALVI 2009). A koncepció teljesen figyelmen kívül hagyta, hogy a magasabban képzettek és a fiatalok falvakból való elköltözését egy szegényebb, sok esetben cigány családok beáramlása követte. Így az 1980-as évekre kistelepülési gettók jöttek létre (HAVAS 1999, LADÁNYI-SZELÉNYI 2004), amely egyben egy új élethelyzetet is teremtett a romák számára, akik már nem csak a településen belül voltak szegregálva, hanem valójában az egész falu izolálttá vált (VIRÁG 2006). 
Melléklet 2. - Az adatfelvételhez használt kérdőívek

\section{Periférikus területen élő hátrányos helyzetủek munkahelymegtartó képessége 1.}

\section{DEMOGRÁFIAI JELLEMZÖK}

1. Hányan élnek Önök együtt közös háztartásban?

\section{fó}

2. Hány család él a háztartásban?

.... család

3. Család/háztartás tagjainak életkora?

\begin{tabular}{|l|l|l|l|l|l|l|l|l|l|}
\hline 1 & 2 & 3 & 4 & 5 & 6 & 7 & 8 & 9 & 10 \\
\hline & & & & & & & & & \\
\hline
\end{tabular}

4. Háztartás tagjainak neme:

1. Férfi

2. Nö

\begin{tabular}{|l|l|l|l|l|l|l|l|l|l|}
\hline 1 & 2 & 3 & 4 & 5 & 6 & 7 & 8 & 9 & 10 \\
\hline & & & & & & & & & \\
\hline
\end{tabular}

5. Milyen tagokból áll a háztartás?

\begin{tabular}{|l|l|l|l|l|l|l|l|}
\hline $\begin{array}{l}\text { 1.Férj, } \\
\text { feleség }\end{array}$ & 2.Élettárs & $\begin{array}{l}\text { 3.Gyermekét } \\
\text { egyedül nevelő } \\
\text { szülö - ha a } \\
\text { gyermek nem él } \\
\text { párkapcsolatban }\end{array}$ & 4.Gyermek & $\begin{array}{l}\text { 5.Felmenö } \\
\text { rokon - } \\
\text { családdal } \\
\text { együtt élő } \\
\text { szülö, } \\
\text { nagyszülő }\end{array}$ & $\begin{array}{l}\text { 6.Más } \\
\text { rokon }\end{array}$ & $\begin{array}{l}\text { 7.Nem } \\
\text { rokon }\end{array}$ & $\begin{array}{l}\text { 8.Egy } \\
\text { edülál } \\
\text { ló a } \\
\text { háztar } \\
\text { táshoz } \\
\text { nem } \\
\text { tartozi } \\
\text { k más } \\
\text { szemé } \\
\text { ly) }\end{array}$ \\
& & & & & & & \\
& & & & & & \\
& & & & & & & \\
\end{tabular}

\begin{tabular}{|l|l|l|l|l|l|l|l|l|l|}
\hline 1 & 2 & 3 & 4 & 5 & 6 & 7 & 8 & 9 & 10 \\
\hline & & & & & & & & & \\
\hline
\end{tabular}


6. A család/háztartás tagjai helyi születésüek?

1. Igen -» ugrás a 10. kérdésre!

2. Nem

\begin{tabular}{|l|l|l|l|l|l|l|l|l|l|}
\hline 1 & 2 & 3 & 4 & 5 & 6 & 7 & 8 & 9 & 10 \\
\hline & & & & & & & & & \\
\hline
\end{tabular}

7. Ha nem helyben született, milyen típusú településről költöztek ide?

1. Főváros

2. Megyei jogú város, mégpedig:

3. Város, mégpedig:

4. Község, mégpedig:

5. Tanya, mégpedig:

\begin{tabular}{|l|l|l|l|l|l|l|l|l|l|}
\hline 1 & 2 & 3 & 4 & 5 & 6 & 7 & 8 & 9 & 10 \\
\hline & & & & & & & & & \\
\hline & & & & & & & & & \\
\hline
\end{tabular}

8. Ha nem Tiszabőn/Szolnokon születtek, miért költöztek ide?

9. Ha nem helyben születtek, hány éve költöztek Tiszaböre/Szolnokra?

\begin{tabular}{|l|l|l|l|l|l|l|l|l|l|}
\hline 1 & 2 & 3 & 4 & 5 & 6 & 7 & 8 & 9 & 10 \\
\hline & & & & & & & & & \\
\hline
\end{tabular}

10. Hová szoktak utazni a falun/városon kívül? Milyen célból?

11. Hol voltak a legtávolabb életükben Tiszabőtől/Szolnoktól?

12. Ha van gyermekük, szívesen engednék/engedték volna el másik településre, akár bentlakásos iskolába tanulni?

1. Igen

2. Nem

\begin{tabular}{|l|l|l|l|l|l|l|l|l|l|}
\hline 1 & 2 & 3 & 4 & 5 & 6 & 7 & 8 & 9 & 10 \\
\hline & & & & & & & & & \\
\hline
\end{tabular}


13. Mi az Ön legmagasabb befejezett iskolai végzettsége?

1. Nem járt iskolába

2. Általános iskola ..... osztály

3. Általános iskolai bizonyítvány

4. Szakmunkásképző iskolai bizonyítvány

5. Szakiskolai oklevél, bizonyítvány

6. Érettségi bizonyítvány, szakképesítés nélkül

7. Érettségi bizonyítvány, szakképesítéssel

8. Érettségire épülő szakképesítő bizonyítvány

9. Felsőfokú szakképesítés

10. Főiskolai diploma, vagy Bsc

11. Egyetemi diploma, vagy Msc

12. Doktori képzés

\begin{tabular}{|l|l|l|l|l|l|l|l|l|l|}
\hline 1 & 2 & 3 & 4 & 5 & 6 & 7 & 8 & 9 & 10 \\
\hline & & & & & & & & & \\
\hline
\end{tabular}

14. Van-e valamilyen szakmája/szakképesítése a család/háztartás tagjainak?

1. Igen, mégpedig

2. Nincs

\begin{tabular}{|l|l|l|l|l|l|l|l|l|l|}
\hline 1 & 2 & 3 & 4 & 5 & 6 & 7 & 8 & 9 & 10 \\
\hline & & & & & & & & & \\
\hline & & & & & & & & & \\
\hline
\end{tabular}

15. A háztartásban élők közül hány 15 év feletti főnek - aki már befejezte a tanulmányait - van rendszeres havi jövedelme, vagy alkalmi munkája? Önálló keresete, nyugdíja, stb. fö

16. A családból, háztartásból hány 25 év feletti fő - aki már befejezte az iskolai tanulmányait és még nem nyugdíjas korú dolgozik a közmunkaprogramban?

........ fö 99. Nyugdíjas korú, vagy tanuló

17. A családból, háztartásból hány olyan főnek van bejelentett munkája, aki már befejezte az iskolai tanulmányait, de még nem nyugdíjas korú?

fó 99. Nyugdíjas korú , vagy tanuló

18. A családból, háztartásból hány, életkor alapján jogosult személy kap szociális juttatásokat, segélyt?

fö 99. Nyugdíjas, vagy tanuló

19. Körülbelül a háztartásukban mennyi pénzböl élnek havonta?

$\mathrm{Ft}$

20. Ez milyen pénzekből tevődik össze? Több válasz lehetséges!

1. Fizetés: ... fö

2. Alkalmi munkabér: ... fö 
3. Ösztöndíj: ... fő

4. GYES, GYED, GYET: ... fó

5. Segélyek: ... fö

6. Rokkant nyugdíj: ... fő

7. Öregségi nyugdíj: ....fö

8. Banki hitel: ... fó

9. Kölcsön: ... fö

10. Szülöi, családi vagy rokoni támogatás: ... fő

11. Egyéb, mégpedig:

21. A családban/háztartásban élőknek milyen tevékenységei vannak? A családból/háztartásból hány fö tartozik a következő csoportokba? Egy személyhez több kategória is tartozhat!

1. Bejelentett munka - teljes munkaidőben -» Tovább a 2. modulra!

2. Bejelentett munka - részmunkaidőben -» Tovább a 2. modulra!

3. Bejelentett munka mellett mellékfoglalkozás -» Tovább a 2. modulra!

4. Saját vállalkozásban dolgozik -» Tovább a 2. modulra!

5. Közmunkaprogramban dolgozik -» Tovább a 3. és a 4. modulra!

6. Aktív korúak ellátását kap (foglalkoztatást helyettesítő támogatásra, vagy egészségkárosodási és gyermekfelügyeleti támogatásra) -» Tovább a 3. és a 4. modulra!

7. Alkalmi munkavégzés (eseti megbízással dolgozó, alkalmi munkás, napszámos) -〉 Tovább a 3. és a 4. modulra!

8. Nem hivatalos munkát végez -» Tovább a 2., 4., és az 5. modulra!

9. Nyugdíjas, mégpedig: -» Tovább az 5. modulra!

10. GYES, GYED, GYET -» Köszönöm a válaszait!

11. Rendszeres szociális ellátást kap -» Tovább a 3. ée 4. modulra!

12. Tanuló -» Köszönöm a válaszait!

13. Nem tanul, nincs munkája, és nincsenek bevételei! -» Tovább a 3. modulra!

\begin{tabular}{|l|l|l|l|l|l|l|l|l|l|}
\hline 1 & 2 & 3 & 4 & 5 & 6 & 7 & 8 & 9 & 10 \\
\hline & & & & & & & & & \\
\hline
\end{tabular}




\title{
Periférikus területen élő hátrányos helyzetủek munkahelymegtartó képessége 2 .
}

\author{
JELENLEG ALKALMAZÁSBAN ÁLLÓK KÉRDÉSEI - Hivatalos/bejelentett \\ munkát végez, amely nem közmunka. Ha a 21. kérdésre 1. 2. 3. 4. 8. válaszok \\ valamelyikét adta!
}

1. Hány évesen dolgozott először? Hány évesen végzett először kereső tevékenységet? Bármilyen hivatalos/nem hivatalos, alkalmi munka, vagy eseti megbizást

.... évesen

2. Hány évesen végzett elöször hivatalos/bejelentett munkát?

.... évesen

3. Milyen munkakörben dolgozik, mivel foglalkozik?

4. Melyik településen dolgozik?

1. Tiszabőn/Szolnokon -» ugrás a 8. kérdésre!

2. Más településen, mégpedig:

3. Változó településeken, mégpedig:

5. Ha nem Tiszabőn/Szolnokon dolgozik, hogyan közlekedik általában a lakóhelyéröl a munkahelyére?

1. Gyalog

2. Távolsági autóbusszal

3. Vonattal

4. Saját/családi autóval

5. Saját/családi motorral

6. Saját vagy családi kerékpárral

7. Céges autóval

8. Céges buszjárattal

9. Ismerőssel, ismerősökkel együtt, annak jármüjével

10. Többféleképpen, mégpedig

11. Más módon, mégpedig

6. Ha nem Tiszabön/Szolnokon dolgozik, támogatják-e a bejárást munkahelyére? Ha igen, milyen formában, és milyen összeggel?

1. Igen, mégpedig:

2. Nem támogatják

7. Ha nem Tiszabőn/Szolnokon dolgozik, hány perc alatt jut el a munkahelyére? perc 
8. Van-e munkaszerződése jelenlegi munkahelyén?

1. Igen

2. Nincs

9. Hogyan sikerült a beilleszkedés a munkahelyére? Voltak-e nehézségek?

1. Könnyü volt a beilleszkedés

2. Pár hónap alatt sikerült beilleszkedni

3. Nehezen illeszkedett be

4. Eddig még nem sikerült beilleszkednie

10. Mennyi pénzt keres a munkahelyén?

$\mathrm{Ft}$

11. Mennyire elégedett a fizetésével?

1. Teljes mértékben

2. Inkább elégedett, mint nem

3. Inkább nem elégedett

4. Egyáltalán nem elégedett

12. Mennyire érzi magát túlterhelve a munkahelyén?

1. Nagyon sokat kell dolgozni

2. Sokat kell dolgozni

3. Éppen megfelelő a munka mennyisége

4. Keveset kell dolgozni

5. Nagyon keveset kell dolgozni

13. Hogyan sikerült a betanulási folyamat a munkahelyére?

1. Gyorsan megtanulta a munkaköri feladatokat

2. Időre volt szüksége, hogy megtanulja a munkaköri feladatokat

3. Nem tudta megtanulni a munkaköri feladatokat

14. Segítettek-e Önnek a betanulási folyamatban?

1. Igen, sokat segítettek

2. Igen, néha segítettek

3. Nem segítettek

15. Többet várnak-e el Öntől, vagy kevesebbet, vagy nem tesznek különbséget?

1. Többet várnak el

2. Nem tesznek különbséget

3. Kevesebbet várnak el

16. Érzi-e a munkahelyén bármilyen hátrányát annak, hogy Ön Tiszabőn/Szolnoknak ezen a részén lakik?

1. Igen

2. Nem -» Tovább a 18. kérdésre! 
17. Ha igen, miben érzi hátrányát?

18. Mennyire stresszes a munkája?

1. Nagyon stresszes

2. Némi stresszel jár

3. Egyáltalán nem stresszes

19. Milyen hosszú időt tölt el egy munkahelyen?

1. Előfordult már, hogy az első héten otthagyta a munkahelyét

2. Többnyire pár hét után elveszíti a munkáját

3. Jellemzően néhány hónapig dolgozik egy munkahelyen

4. Általában több, mint egy évig dolgozik egy munkahelyen

20. Hány hónapig tartott a leghosszabb egybefüggő munkavégzése?

hónapig

21. Jelenlegi munkahelyét megelőzően, jelentkezései alapján milyen gyakran hívták be állásinterjúra?

1. Mindig behívtak állásinterjúra

2. Többnyire behívtak állásinterjúra

3. Többnyire nem hívtak be állásinterjúra

4. Egyáltalán nem hívtak be állásinterjúra

5. Nem jelentkezett még munkahelyre

22. Hogyan reagált az esetleges álláskeresési kudarcokra?

1. Nem voltak rá hatással

2. Több próbálkozásra ösztönözték

3. Egy időre elvették a kedvét és az önbizalmát a munkakereséstől

4. Egy idő után feladata és nem keresett tovább

5. Nem érték álláskeresési kudarcok

23. Hány hónapja dolgozik jelenlegi munkahelyén? hónapja

24. Hogyan értékelik feletteseik a munkáját?

25. Maximálisan elégedettek

26. Ritkán merül fel kifogás

27. Időnként kap kritikát

28. Szinte mindig elégedetlenek

29. Nem foglalkoznak vele/nem értékelik 
30. Van-e bármilyen elörelépési lehetősége jelenlegi munkahelyén?

1. Igen, mégpedig

2. Nincs

31. Mennyire szereti jelenlegi munkáját?
1. Kifejezetten szereti
2. Szereti
3. Szereti is, meg nem is
4. Nem szereti
5. Egyáltalán nem szereti

32. Megfordult-e már a fejében, hogy munkahelyet váltson?

1. Igen

2. Nem -» Tovább a 39. kérdésre!

33. Ha igen, miért?

34. Milyen szempontokat vett figyelembe a munkája elvállalásakor?

35. Hogyan találta jelenlegi munkahelyét?
1. Interneten keresztül
2. Újsághirdetésen keresztül
3. Munkaügyi központon, kirendeltségen/Kormányablakon keresztül
4. Polgármesteri hivatal segítségével
5. Személyesen, vagy telefonon érdeklődött
6. Családtagok, rokonok, ismerősök segítségével
7. Egyéb módon, mégpedig:

36. Hogyan tudja összeegyeztetni a családi és a munkahelyi kötelezettségeit?

0 . Nincs családja

1. Nem okoz gondot kizárólag a munkával foglalkozni és az otthoni dolgokat kizárni

2. Időnként a családi és magánéleti problémák elterelték a figyelmét a munkáról

3. Az otthoni problémák gyakran a munka rovására mennek

4. Családi és magánéleti problémák esetén nem tudja ellátni a munkáját

37. Mivel nehezebb tiszabői/Szolnok ezen környékének lakos(a)ként munkát találni, mint a környékbeli településeken lakva?

38. Hány munkahelye volt eddig? 
39. Mi volt a váltások legfőbb oka?

40. Ön szerint utasították-e már el egy munkafelvétel során azért, mert Tiszabön/Szolnoknak ezen a részén lakik?
1. Igen
2. Nem

41. Érte-e bármilyen hátrányos megkülönböztetés a munkára való jelentkezés során?

1. Igen, mégpedig

2. Nem

42. Érte-e bármilyen megkülönböztetés a munkavégzés során? A tájékoztatásban, eligazításban, munkaeszközök, vagy a pihenő során másként kezelték-e Önt, mint a többi kollégát?

1. Igen, mégpedig

2. Nem 


\section{Periférikus területeken élő hátrányos helyzetüek munkahelymegtartó képessége 3.}

HA JELENLEG NEM DOLGOZIK - Nem tanuló és aktív korú 16 év feletti, de még nem nyugdíjas korú. Ha a 21. kérdésre 5. 6. 7. vagy 11. választ adott!

1. Hány évesen dolgozott először? Hány évesen végzett először kereső tevékenységet?

Bármilyen hivatalos/nem hivatalos, alkalmi munka, eseti megbizás

1. ..... évesen

2. még soha nem dolgozott -» ugrás a 3. kérdésre!

2. Hány évesen végzett először hivatalos/bejelentett munkát?

1. .... évesen

2. még nem végzett hivatalos munkát

3. Keresett-e hivatalos munkát az elmúlt egy hónapban?

1. Igen

2. Nem

4. Milyen gyakran keres munkát?

1. Minden nap

2. Hetente néhány alkalommal

3. Hetente

4. Havonta néhányszor

5. Havonta

6. Ritkábban

7. Nem keres munkát -» Ugrás a 6. kérdésre!

5. Hogyan próbál munkalehetőséghez jutni? Milyen munkakeresési módszerei vannak? Több válasz lehetséges!

1. Interneten keresztül

2. Újsághirdetésen keresztül

3. Munkaügyi központ, kirendeltség/Kormányablak segítségével

4. Polgármesteri hivatal segítségével

5. Személyesen, vagy telefonon érdeklődik

6. Családtagok, rokonok, vagy ismerősök segítségével

7. Egyéb módon, mégpedig:

6. Milyen szoros kapcsolatot tart a munkaügyi központtal, kirendeltséggel?

1. Hetente felkeresi

2. Két kötelező jelentkezés között is felkeresi

3. Csak a kötelezö jelentkezések alkalmával keresi fel

4. Nem tart kapcsolatot a munkaügyi központtal, kirendeltséggel 
7. Jelent-e bármilyen problémát, vagy ütközik-e bármilyen akadályba a munkaügyi központ, kirendeltség/Kormányablak felkeresése?

1. Igen, mégpedig:

2. Nem jelent problémát

8. Jelentkezései alapján milyen gyakran hívják be állásinterjúra?

1. Mindig behívnak állásinterjúra

2. Többnyire behívnak állásinterjúra

3. Többnyire nem hívnak be állásinterjúra

4. Egyáltalán nem hívnak be állásinterjúra

5. Nem jelentkezett még munkahelyre -» Ugrás a 10. kérdésre!

9. Hogyan reagál az esetleges álláskeresési kudarcokra?

1. Nincs Önre hatással

2. Még több próbálkozásra ösztönzik

3. Elveszik a kedvét egy időre a munkakereséstől

4. Feladja és nem keres tovább

5. Nincsenek álláskeresési kudarcai

10. Ha találna munkát, munkába tudna-e állni két héten belül?

1. Igen -» Ugrás a 12. kérdésre!

2. Nem

11. Ha nem, mi akadályozza a munkába állásban?

12. Milyen szempontokat venne figyelembe egy munka elvállalásakor?

13. Mikor végzett utoljára kereső tevékenységet, olyan munkát, amiért pénzt kapott? (nem hivatalos/fekete munka, alkalmi munka, közmunka)

1. ..... hónapja

2. Jelenleg is végez kereső tevékenységet, mégpedig

3. Soha nem végzett még kereső tevékenységet

14. Mikor végzett utoljára hivatalos/bejelentett kereső tevékenységet, amely nem közmunka volt? Milyen munkát végzett? Mennyi ideig tartott? Hogyan fejeződött be a munkavégzés?

1. .......... hónapja

2. még nem végzett hivatalosan kereső tevékenységet

15. Milyen munkakörben dolgozott utoljára? 
16. Hány hónapig tartott a leghosszabb egybefüggő munkavégzése? hónapig

17. Hány munkahelye volt eddig?

18. Mi volt a váltások legfőbb oka?

19. Volt-e munkaszerződése legutóbbi munkahelyén?
1. Igen
2. Nem
3. Még nem volt munkahelye -» Ugrás a 38. kérdésre!

20. Melyik településen dolgozott utoljára?

1. Tiszabőn/Szolnokon -» Ugrás a 24. kérdésre!

2. Más településen, mégpedig:

3. Változó településeken, mégpedig:

21. Ha nem Tiszabőn/Szolnokon dolgozott, hogyan közlekedett a munkahelyére?
1. Gyalog
2. Távolsági autóbusszal
3. Vonattal
4. Saját/családi autóval
5. Saját/családi motorral
6. Saját vagy családi kerékpárral
7. Céges autóval
8. Céges buszjárattal
9. Ismerőssel, ismerősökkel, annak jármüjével
10. Többféleképpen, mégpedig
11. Más módon, mégpedig

22. Ha nem Tiszabőn/Szolnokon dolgozott utoljára, támogatták-e a bejárást munkahelyére? Ha igen, milyen formában, és milyen összeggel?

1. Igen, mégpedig: Ft-tal

2. Nem

23. Ha nem Tiszabőn/Szolnokon dolgozott utoljára, hány perc alatt jutott el a munkahelyére? perc alatt

24. Hogyan sikerült a beilleszkedés a legutóbbi munkahelyére?

1. Könnyü volt a beilleszkedés

2. Pár hónap alatt sikerült a beilleszkedés

3. Nehezen illeszkedett be

4. Nem sikerült beilleszkednie 
25. Mennyi volt a havi fizetése legutóbbi munkahelyén?

$\mathrm{Ft}$

26. Mennyire volt elégedett a fizetésével legutóbbi munkahelyén?

1. Teljes mértékben elégedett volt

2. Inkább elégedett volt, mint nem

3. Inkább nem volt elégedett

4. Egyáltalán nem volt elégedett

5. Nem vonatkozik rá

27. Mennyire érezte túlterhelve magát legutóbbi munkahelyén?

1. Nagyon sokat kellett dolgozni

2. Sokat kellett dolgozni

3. Éppen megfelelő volt a munka mennyisége

4. Keveset kellett dolgozni

5. Nagyon keveset kellett dolgozni

28. Hogyan sikerült a betanulási folyamat? Voltak-e nehézségek? Gyorsan megtanulta a munkaköri feladatokat?

1. Gyorsan megtanulta a munkaköri feladatokat

2. Időre volt szüksége, hogy megtanulja a munkaköri feladatokat

3. Nem tudta megtanulni a munkaköri feladatokat

29. Segítettek-e Önnek a betanulási folyamatban?

1. Igen, sokat segítettek

2. Igen, néha segítettek

3. Nem segítettek

30. Többet vártak-e el Öntől felettesei, vagy kevesebbet, vagy nem tettek különbséget?

1. Többet vártak el

2. Nem tettek különbséget

3. Kevesebbet vártak el

31. Érezte-e bármilyen hátrányát a munkája során annak, hogy Ön Tiszabőn/Szolnoknak ezen a részén él?

1. Igen, mégpedig:

2. Nem

32. Mennyire volt stresszes a legutóbbi munkahelye?

1. Nagyon stresszes volt

2. Némi stresszel járt

3. Nem volt stresszes

33. Általában milyen hosszú időt tölt el egy munkahelyen?

1. Előfordult már, hogy az első héten otthagyta a munkahelyét, vagy elküldték

2. Többnyire pár hét után elveszíti a munkáját

3. Jellemzően néhány hónapig dolgozik egy munkahelyen

4. Általában több, mint egy évig dolgozik egy munkahelyen 
34. Hogyan találta legutóbbi munkahelyét?

1. Interneten keresztül

2. Újsághirdetésen keresztül

3. Munkaügyi központon, kirendeltségen/Kormányablakon keresztül

4. Polgármesteri hivatal segítségével

5. Személyesen, vagy telefonon érdeklödött

6. Családtagok, rokonok, ismerősök segítségével

7. Egyéb módon, mégpedig:

35. Hogyan tudta összeegyeztetni a családi és a munkahelyi kötelezettségeit?

0 . Nincs családja

1. Nem okozott gondot kizárólag a munkával foglalkozni és az otthoni dolgokat kizárni

2. Időnként a családi és magánéleti problémák elterelték a figyelmét a munkáról

3. Az otthoni problémák gyakran a munka rovására mentek

4. Családi és magánélet problémák esetén nem tudta ellátni a munkáját

36. Okozott-e gondot a határidők betartása?

1. A feladatokat mindig határidőre teljesítette

2. Határidős feladatait az utolsó pillanatra halasztotta

3. Előfordult, hogy a határidős feladatokkal késett

4. Gyakran előfordult, hogy a határidős feladatokkal késett

37. Hogyan értékelték felettesei a munkáját?

1. Maximálisan elégedettek voltak

2. Ritkán merült fel kifogás

3. Időnként kapott kritikát

4. Szinte mindig elégedetlenek voltak

5. Nem tudja

38. Milyen munkalehetőségei vannak? Hová tudna elmenni dolgozni?

39. Milyen munkát vállalna el, és havonta legalább mekkora fizetésért?

1. Végzettségtől, korábbi munkakörtől eltérő állásokat, Ft-ért

2. Végzettségnek, korábbi munkakörnek megfelelő állásokat, Ft-ért

3. Minden állást elvállalna, ..... Ft-ért

4. Nem vállalna semmilyen munkát

40. Hány kilométert lenne hajlandó utazni naponta egy munkahelyre? $\mathrm{km}-\mathrm{t}$

0 . nem hajlandó utazni a munkahelyre 
41. Vállalna-e olyan munkát, amely miatt csak hetente tudna hazajárni?
1. Igen
2. Nem

42. Van-e olyan egészségügyi problémája, amely akadályozza Önt a munkavégzésben?
1. Igen
2. Nincs

43. Le van-e százalékolva? Ha igen, milyen mértékben?
1. Igen, ..... \%
2. Nem

44. Milyen tényezők akadályozzák Önöket a munkavégzésben? Több válasz is lehetséges!

1. Munkahelyek hiánya

2. Alulképzettség, vagy szakma hiánya

3. Nem megfelelö, elavult szakma

4. Közlekedési nehézségek, közlekedési eszközök hiánya

5. Tiszabö/Szolnok ezen környékének elhelyezkedése

6. Életkora

7. Neme

8. Munkatapasztalat hiánya

9. Család megléte/gyerekek

10. Egyéb, mégpedig:

45. Ön szerint utasították-e már el egy munkafelvétel során azért, mert Tiszabön/Szolnoknak ezen környékén lakik?
1. Igen
2. Nem

46. Érte-e bármilyen hátrányos megkülönböztetés a munkára való jelentkezés során?

1. Igen, mégpedig

2. Nem

47. Érte-e bármilyen megkülönböztetés a munkavégzés során? A tájékoztatásban, eligazításban, munkaeszközök, vagy a pihenő során másként kezelték-e Önt, mint a többi kollégát?

1. Igen, mégpedig

2. Nem

48. Ön szerint mivel nehezebb tiszaböi/Szolnok ezen környékének lakos(a)ként munkát találni, mint a környékbeli településeken élve? 


\section{Periférikus területeken élö hátrányos helyzetüek munkahelymegtartó képessége 4.}

Ha a 21. kérdésre 5., 6., 7., 8., 9., 10., 11. választ adott!

\section{KÖZMUNKAPROGRAMBAN RÉSZT VEVÖK KÉRDÉSEI}

1. Dolgozik-e Ön a közmunkaprogramban?

1. Igen

2. Nem -» ugrás a 6. kérdésre!

2. Hogyan és hányszor került be a közmunkaprogramba? Kérem, mondja el a folyamatot!

3. Az elmúlt évben (12 hónapban) hány hónapot, illetve napi hány órát tudott dolgozni a közmunkaprogramban?

hónapot órát

4. Szereti-e a programban végzett munkáját?

1. Igen, kifejezetten szereti

2. Inkább szereti

3. Is-is

4. Inkább nem szereti

5. Egyáltalán nem szereti

5. Mivel foglalkozik jelenleg a közmunkaprogramban?

-» Ugrás a 9. kérdésre!

6. Ha jelenleg nem vesz részt benne, dolgozott-e már a közmunkaprogramban?

1. Igen

2. Nem -» Ugrás a 11. kérdésre!

7. Ha igen, mikor dolgozott utoljára a közmunkaprogramban, és összesen hány hónapot? hónapja, összesen hónapot

8. Mi az oka, hogy jelenleg nem vesz részt a közmunkaprogramban?

9. Mennyire (volt) elégedett a közmunkaprogramban kapott fizetésével?

5. Teljes mértékben

6. Inkább elégedett, mint nem

7. Inkább nem elégedett

8. Egyáltalán nem elégedett 
10. Javított-e a család/háztartás anyagi helyzetén a közmunkaprogramban való részvétel?

1. Sokat javított

2. Valamelyest javított

3. Nem javított

4. Kicsit rosszabb lett

5. Sokkal rosszabb lett

11. Utasították már el a közmunkára való jelentkezés során?

1. Igen

2. Nem -» Ugrás a 13. kérdésre!

12. Ha igen, mi volt az oka az elutasításnak?

13. Milyen pozitív/negatív tapasztalatai van a közmunkaprogrammal kapcsolatban?

Pozitív:

Negatív:

14. Hogyan közlekedik általában a lakóhelyéről a munkahelyére?

1. Gyalog

2. Távolsági autóbusszal

3. Vonattal

4. Saját/családi autóval

5. Saját/családi motorral

6. Saját vagy családi kerékpárral

7. Céges autóval

8. Céges buszjárattal

9. Ismerőssel, ismerősökkel együtt, annak jármüjével

10. Többféleképpen, mégpedig

11. Más módon, mégpedig

15. Mennyire érzi/érezte magát túlterhelve a közunkaprogramban?

1. Nagyon sokat kell dolgozni

2. Sokat kell dolgozni

3. Éppen megfelelő a munka mennyisége

4. Keveset kell dolgozni

5. Nagyon keveset kell dolgozni

16. Vannak-e, vagy voltak-e problémák/viták a kollégáival?

1. Sok probléma és vita van a munkatársakkal

2. Előfordulnak problémák és viták a munkatársakkal

3. Egyáltalán nincs probléma és vita a munkatársakkal

17. Hogyan értékelik/értékelték felettesei a közmunkaprogramban végzett munkáját?

1. Maximálisan elégedettek

2. Ritkán merül fel kifogás 

3. Időnként kap kritikát
4. Szinte mindig elégedetlenek
5. Nem foglalkoznak vele/nem értékelik
6. Nem tudja

18. Milyen alapvető szabályoknak kell/kellett megfelelnie a közmunkaprogramban? Több válasz lehetséges!
1. Pontos érkezés
2. Határidők tartása
3. Precíz munkavégzés
4. Egyéb:

19. Érte-e bármilyen hátrányos megkülönböztetés a közmunkára való jelentkezés során?

1. Igen, mégpedig

2. Nem

20. Érte-e bármilyen megkülönböztetés a közmunkaprogram során? A tájékoztatásban, eligazításban, munkaeszközök, vagy a pihenő során másként kezelték-e Önt, mint a többi kollégát?

1. Igen, mégpedig

2. Nem

21. Kapott-e már állandó munkát a közmunkaprogramban végzett munkáját követően?

1. Igen

2. Nem 


\section{Melléklet 3. - Félig strukturált interjúvázlat}

1. Kérem, meséljen a település/a telep kialakulásáról és változásairól!

2. Melyek a leginkább jellemző nehézségek a faluban/telepen élő emberek körében?

3. Jellemzően hol, mely munkahelyeken dolgoznak az itt élő emberek?

4. Hogyan látja a településen/a telepen élő emberek elhelyezkedési, és munkamotivációját?

5. Milyen alternatív bevételi források, jövedelemszerzési lehetőségek fedezhetők fel az itt élő emberek körében?

6. Elöfordul-e alkohol, vagy kábítószer használata a faluban/a telepen?

7. Honnan tudják beszerezni itt élő emberek mindennapi szükségleteket (ruházat, élelem, stb...)?

8. Előfordul-e a településen/telepen az uzsorakamatra történő kölcsönfelvétel?

9. Számíthatnak-e segítségre az itt élő emberek? Ha igen, kiktől és milyen segítségre számíthatnak?

10. Éri-e bármilyen hátrány a faluban/a telepen élőket kizárólag azért mert itt élnek? 
Melléklet 4. - Tiszabőről készült fényképek

1. kép - Egy tiszaböi ház udvara 1.

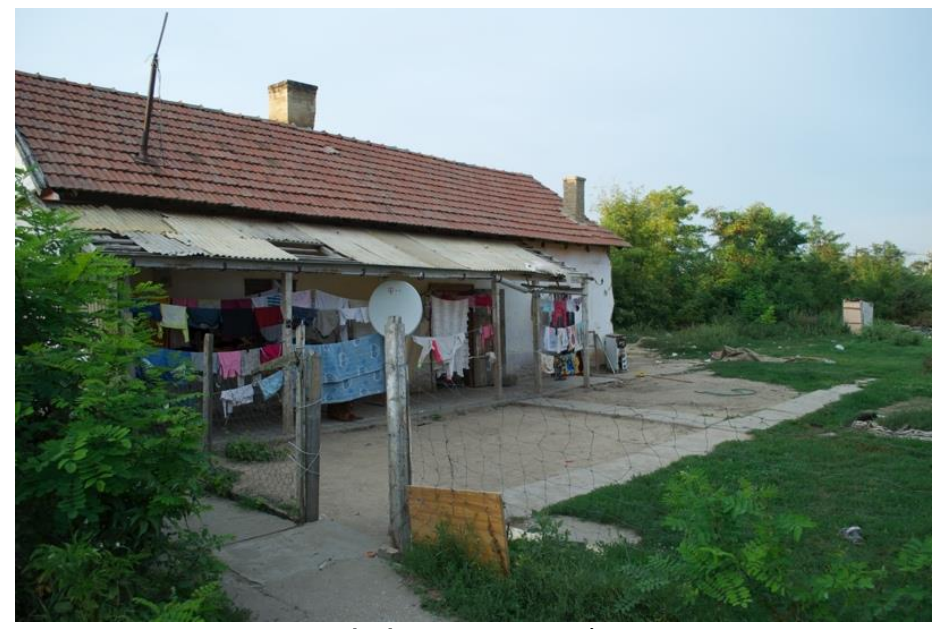

Készitette: MITRIK DÓRA

2. kép - Félig lebontott ház Tiszabö szélén

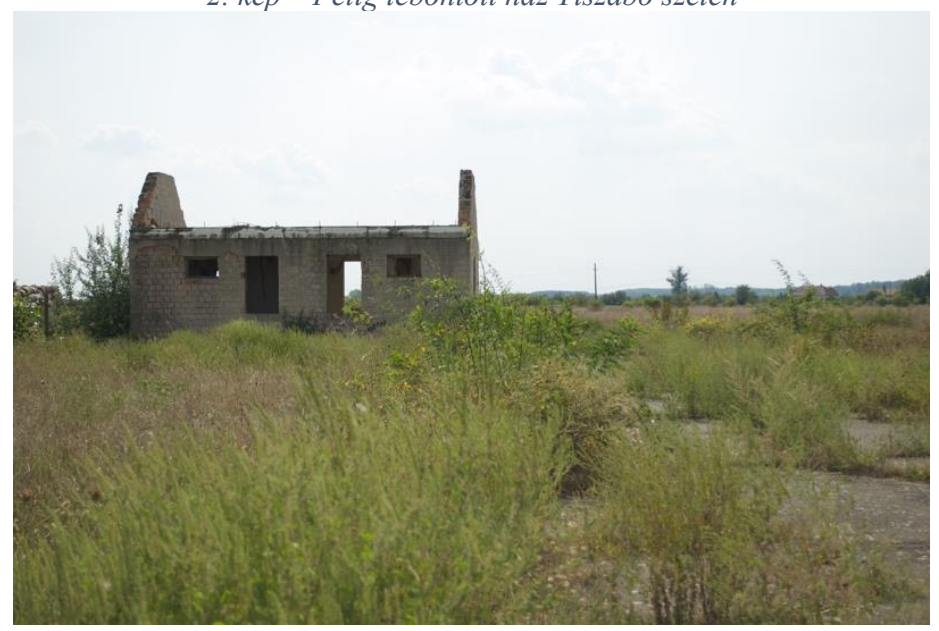

Készítette: MITRIK DÓRA

3. kép - Egy tiszabői ház udvara

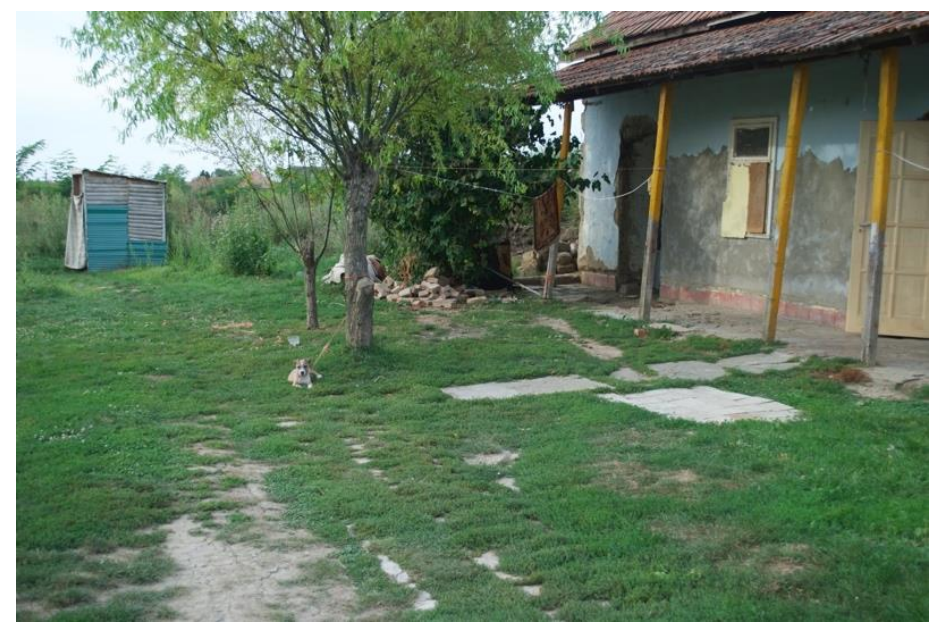

Készitette: MITRIK DÓRA 
4. kép - Tiszabői utcakép, beépitetlen telkekkel

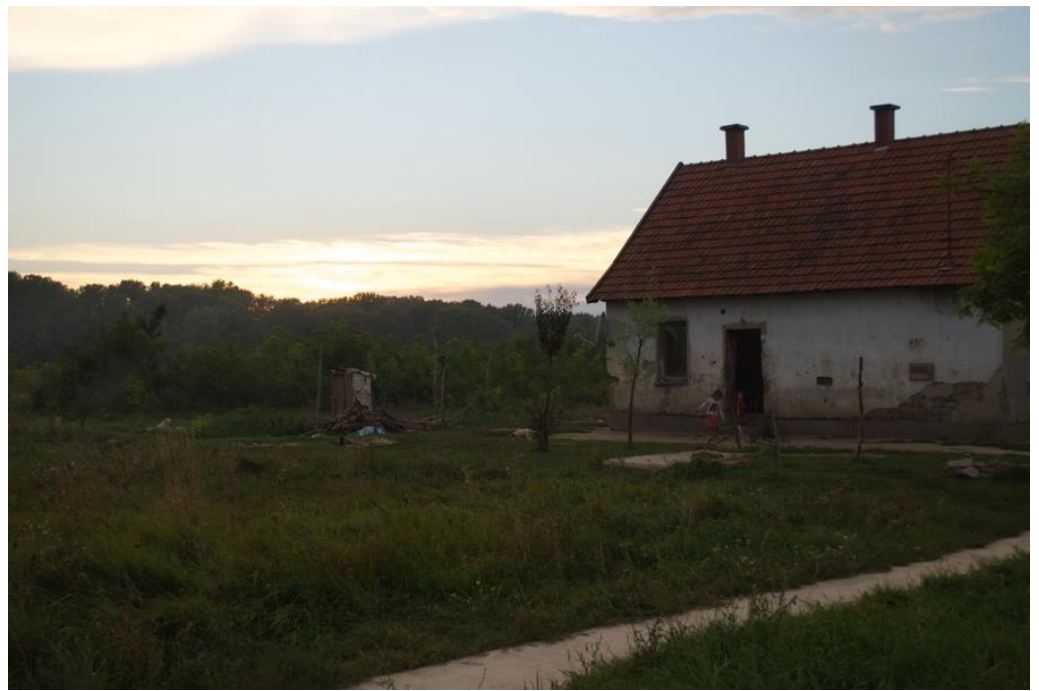

Készitette: MITRIK DÓRA

\section{5. kép - Tiszaböi udvar, sertésekkel}

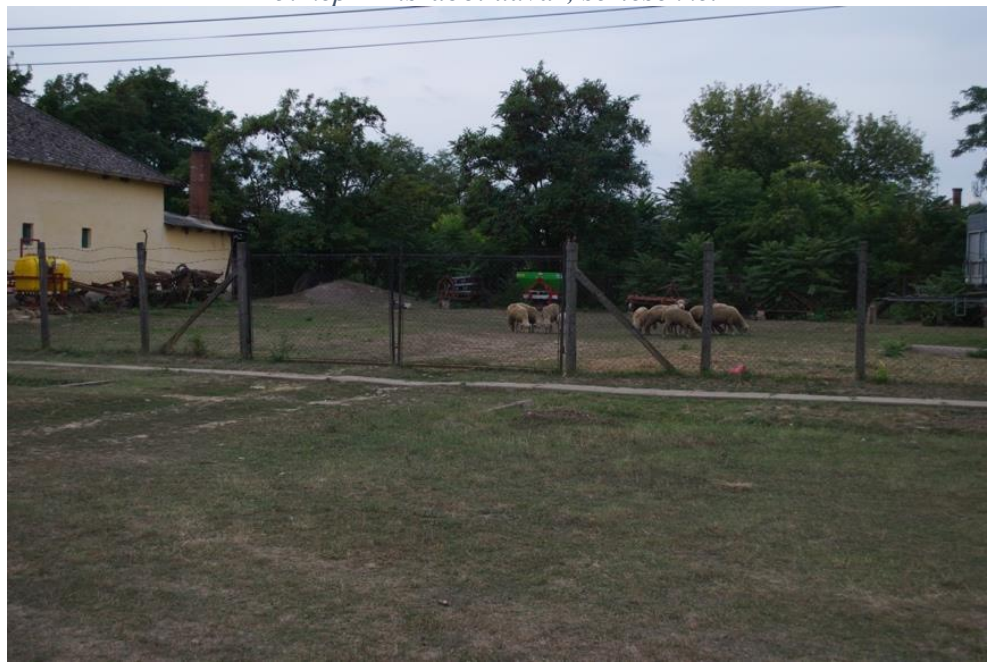

Készítette: MITRIK DÓRA

5. kép - Tiszabői mezögazdasági vállalkozás munkába indulása

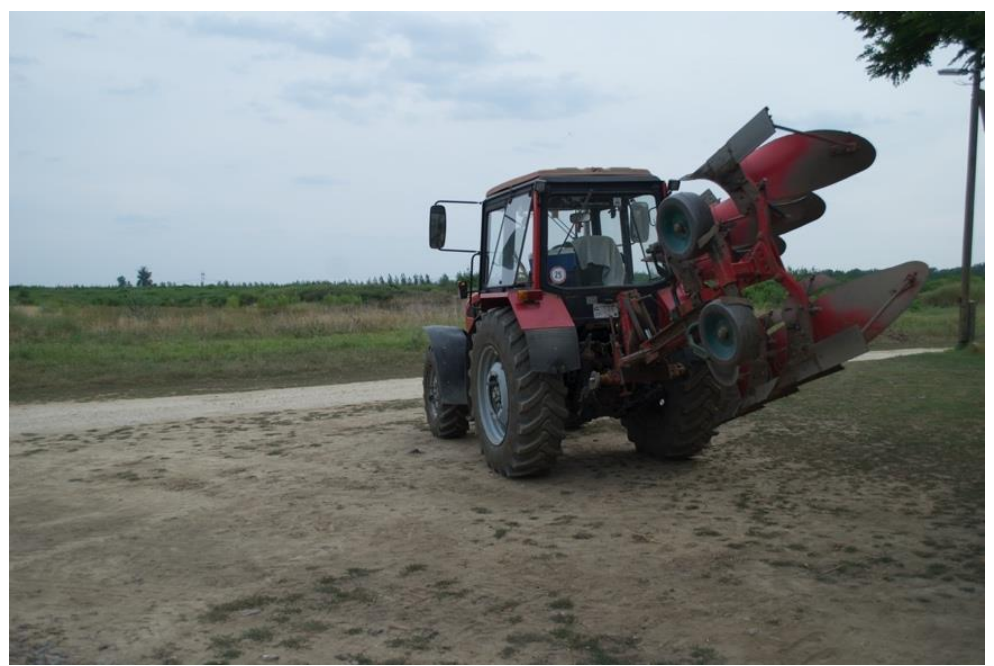

Készitette: MITRIK DÓRA 
6. kép - Egy tiszaböi lakás belsö képe

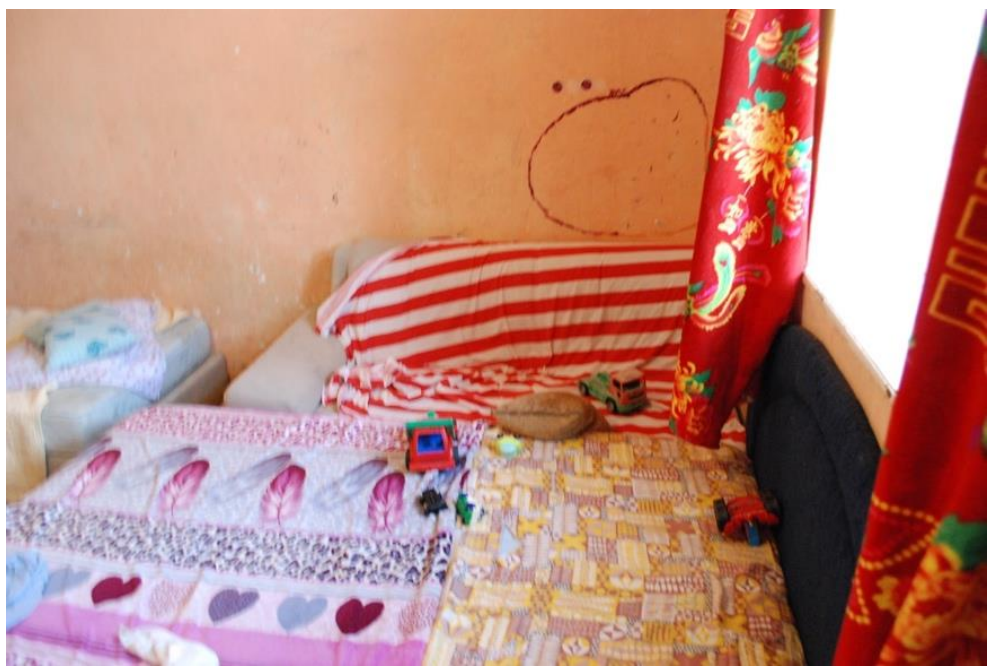

Készitette: MITRIK DÓRA

7. kép - Az egykor müködö Tisza ABC

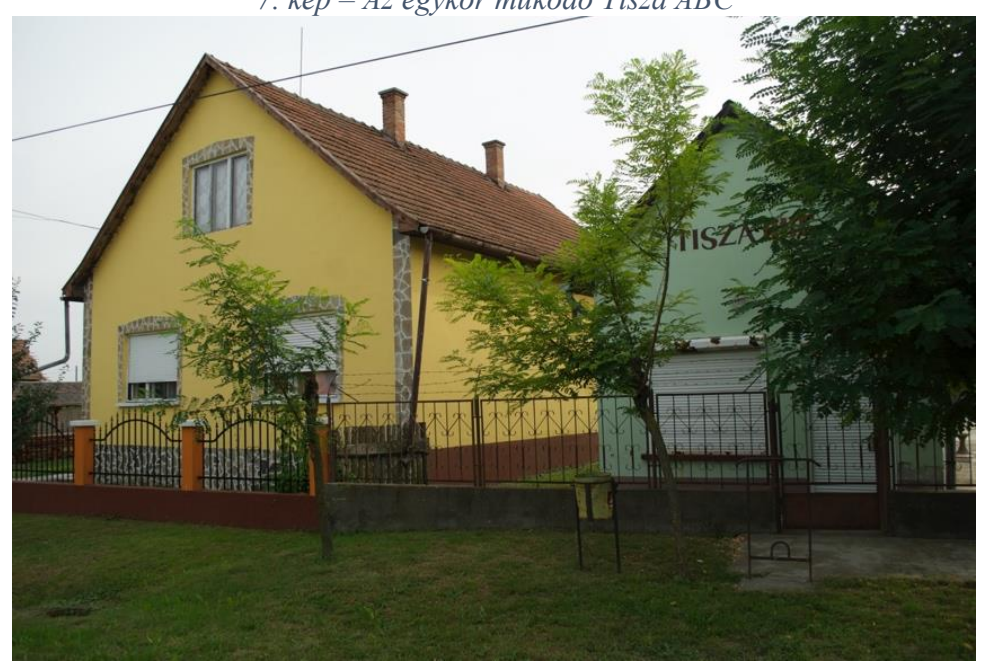

Készitette: MITRIK DÓRA

8. kép - A tiszaböi általános iskola homlokzata a felújitás elött

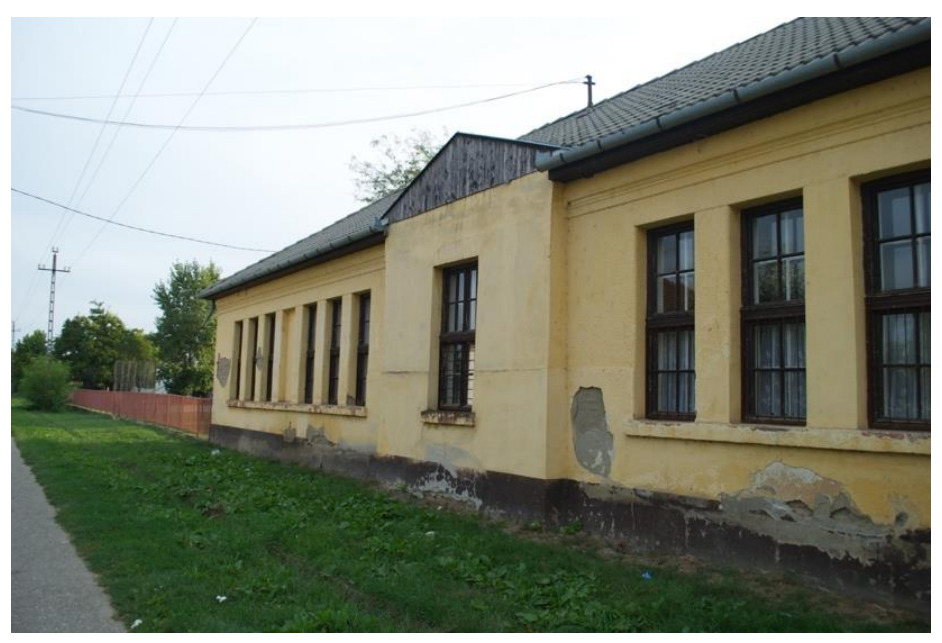

Készitette: MITRIK DÓRA 
9. kép - A tiszaböi általános iskola udvara a felújitás elött

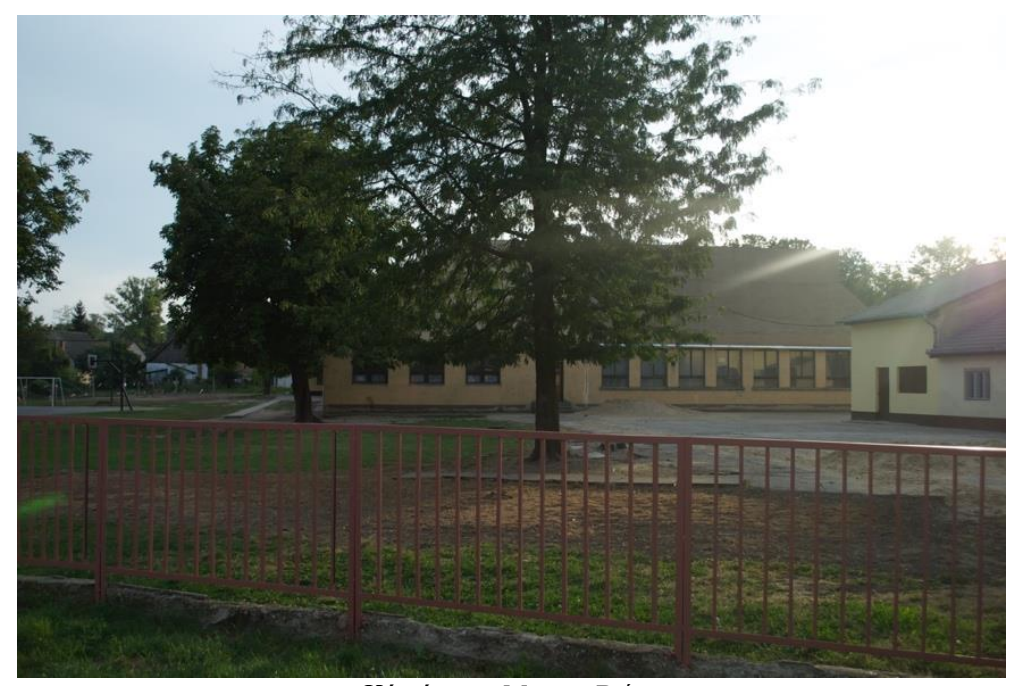

Készitette: MITRIK DÓRA

10. kép - Az önkormányzat fóliasátrai 1.

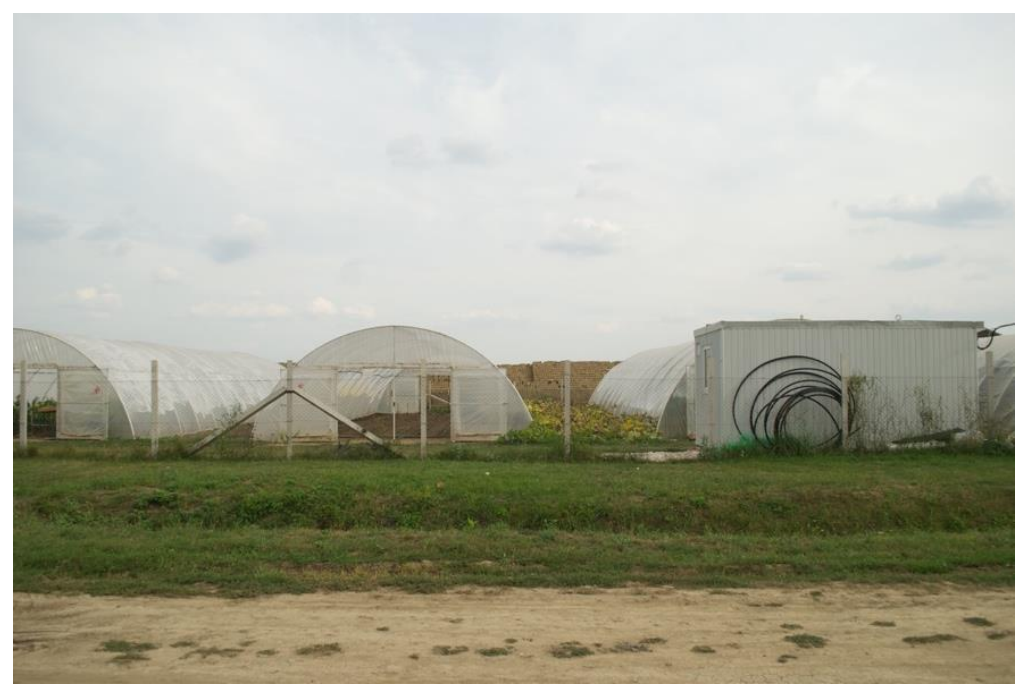

Készitette: MITRIK DÓRA

11. kép - Az önkormányzat fóliasátrai 2.

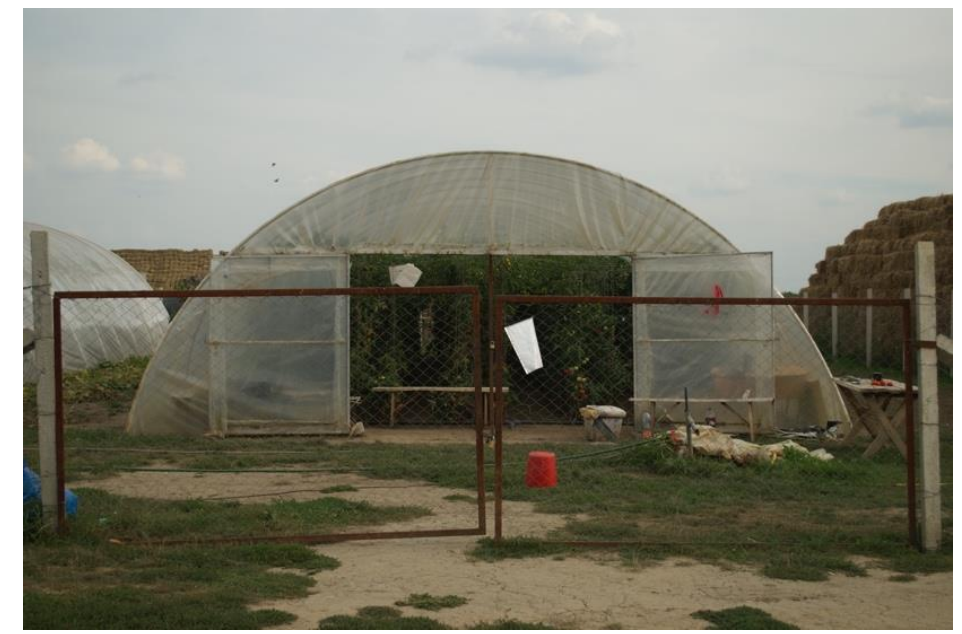

Készitette: MITRIK DÓRA 


\section{2. kép - Tiszaböi látkép az üres telkekkel}

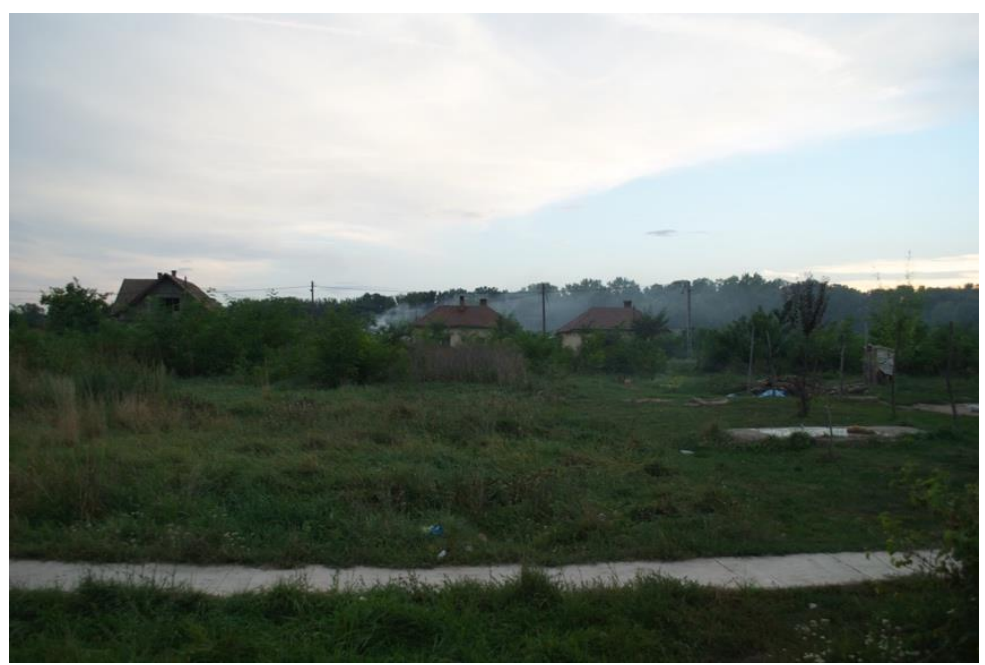

Készitette: MITRIK DÓRA

13. kép-Tiszabö látképe

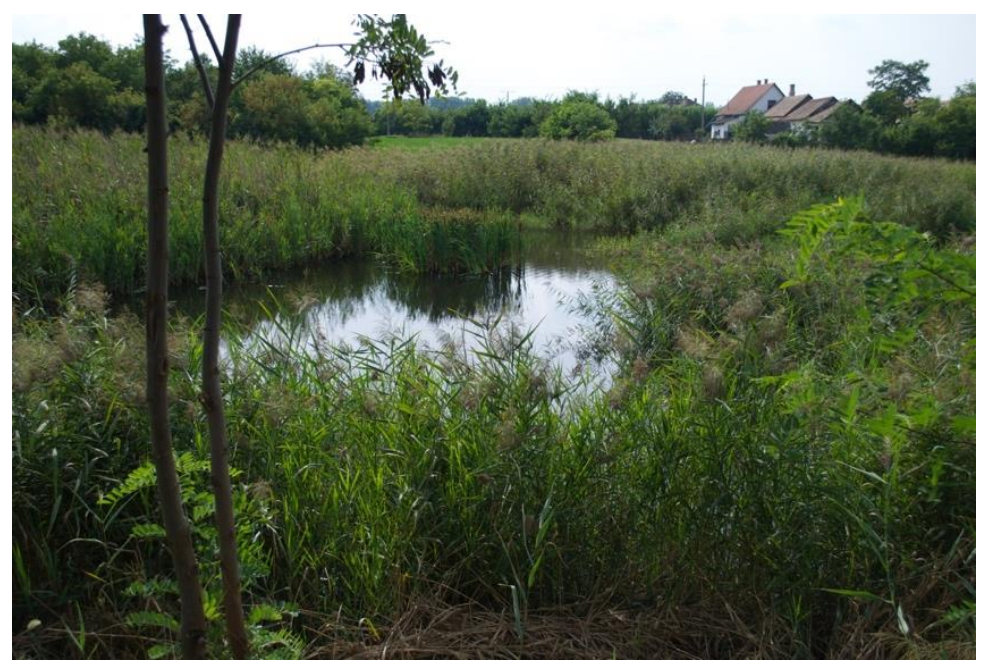

Készítette: MITRIK DÓRA

14. kép - Tiszabői utcakép

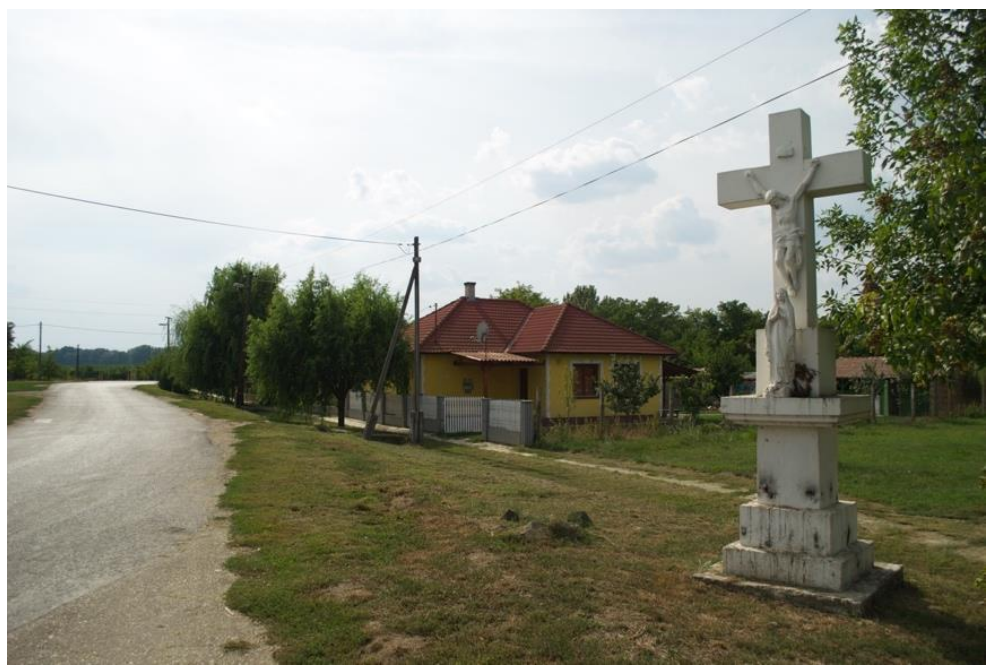

Készitette: MITRIK DÓRA 
15. kép - Tiszaböi utcakép

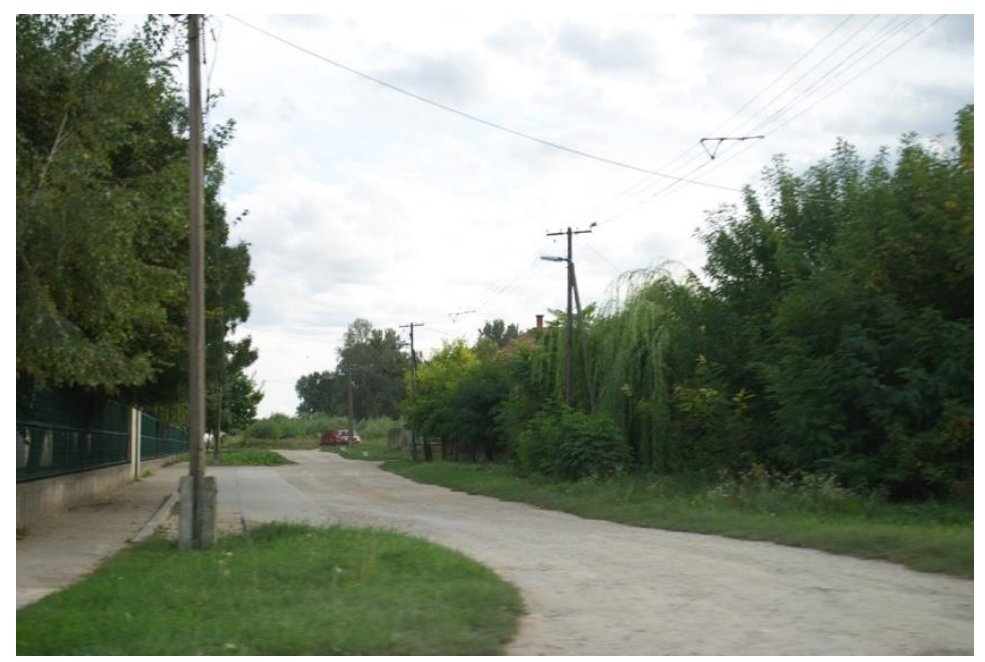

Készitette: MITRIK DÓRA

16. kép - Tiszaböi „,foghijas” utcakép a jellegzetes, üresen álló telkekkel

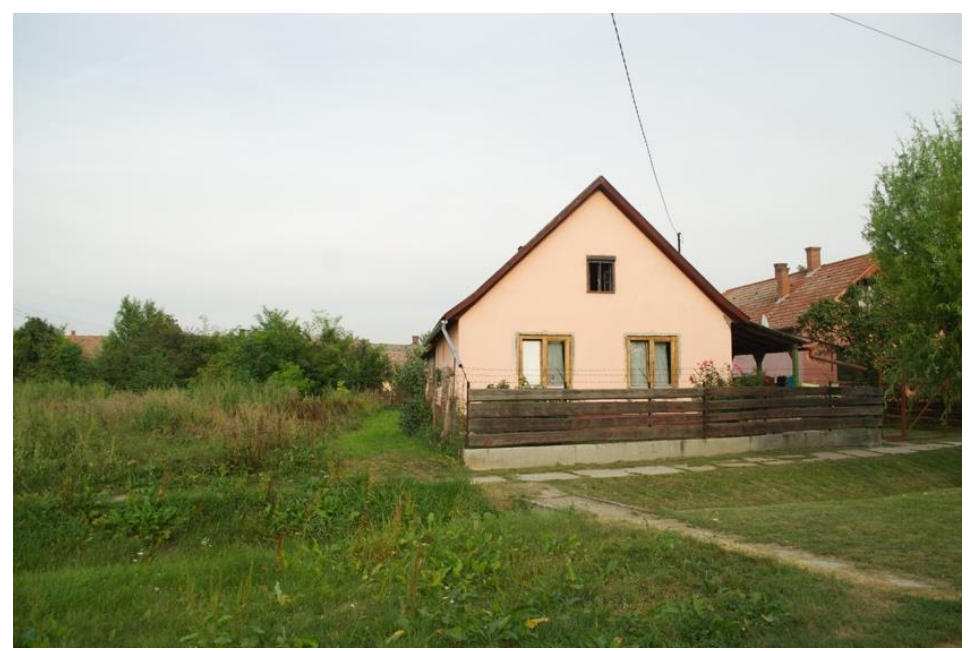

Készitette: MITRIK DÓRA

17. kép - Tiszaböi utcakép

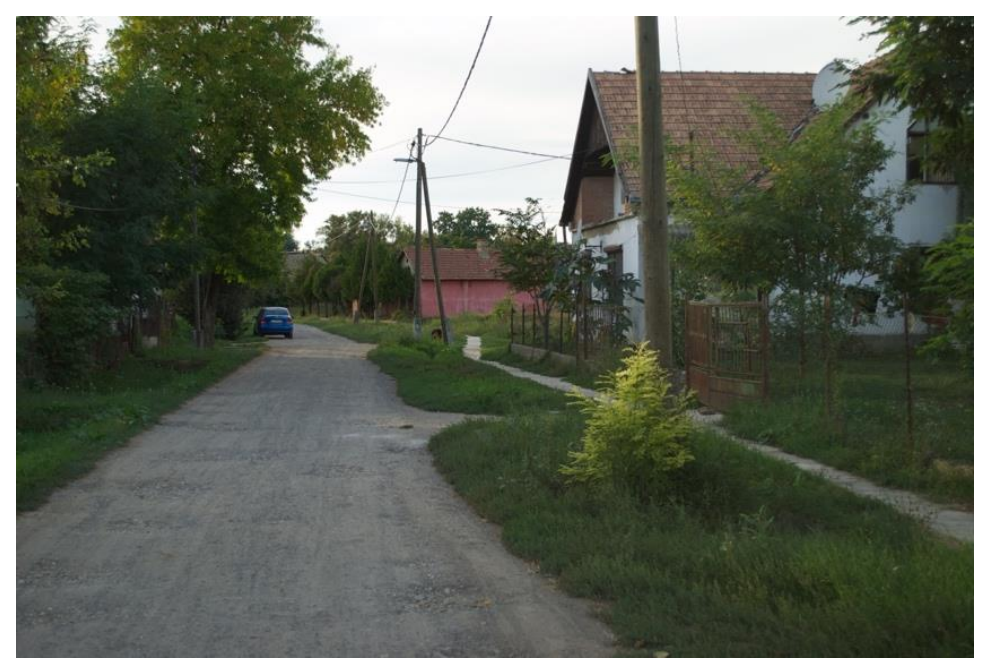

Készitette: MITRIK DÓRA 
18. kép - Egy tiszaböi ház udvarán berendezett edzöterem

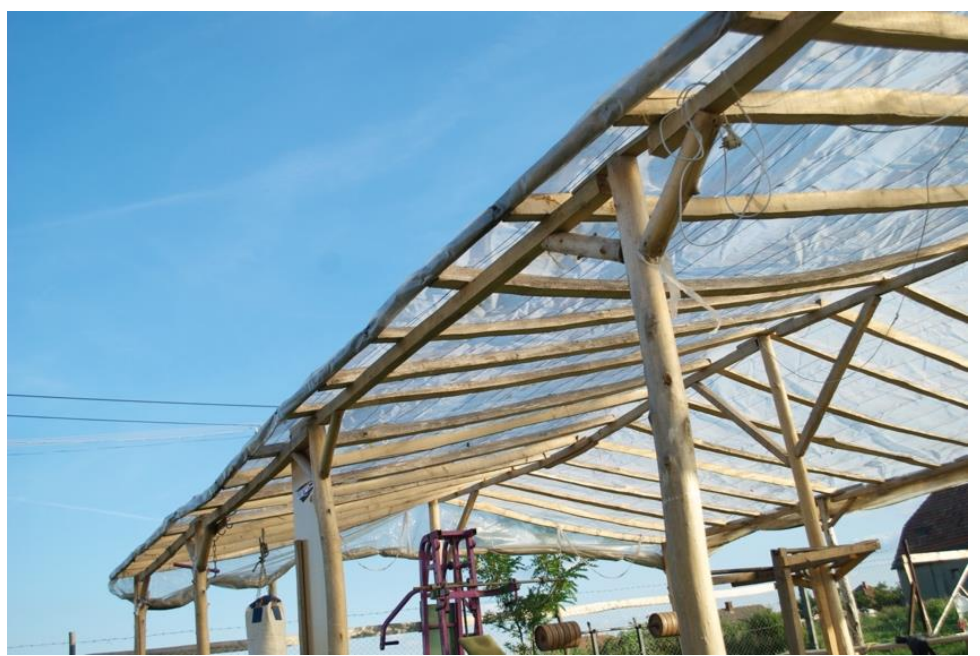

Készitette: MITRIK DÓRA

19. kép - Az egykori téesz épülete a „,Kinai” negyedben

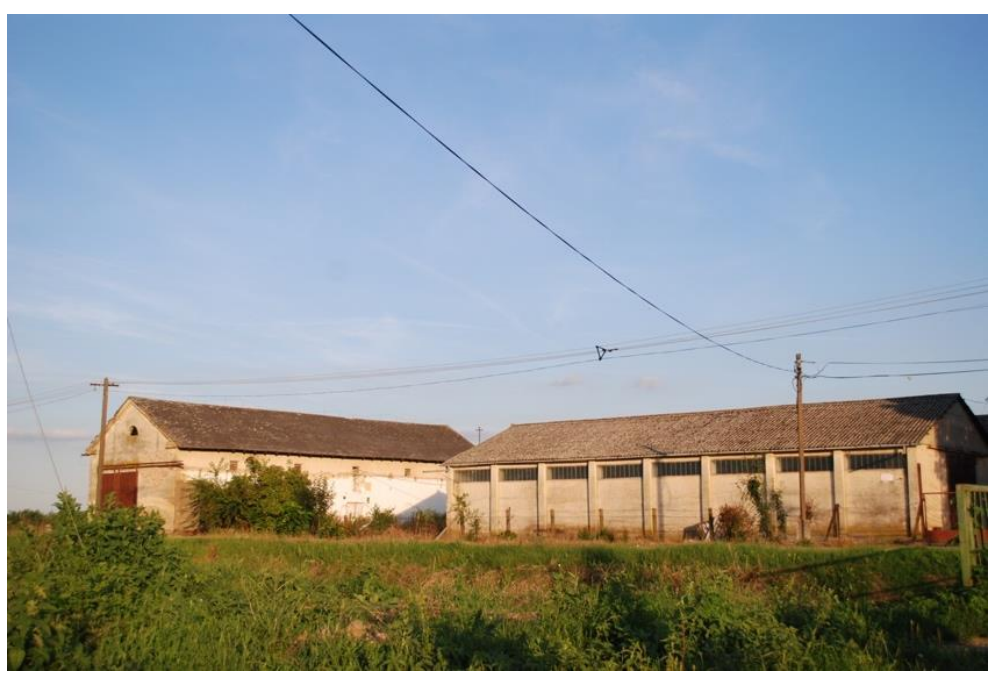

Készitette: MITRIK DÓRA

20. kép-Élelmiszerbolt a „Kínai” negyedben

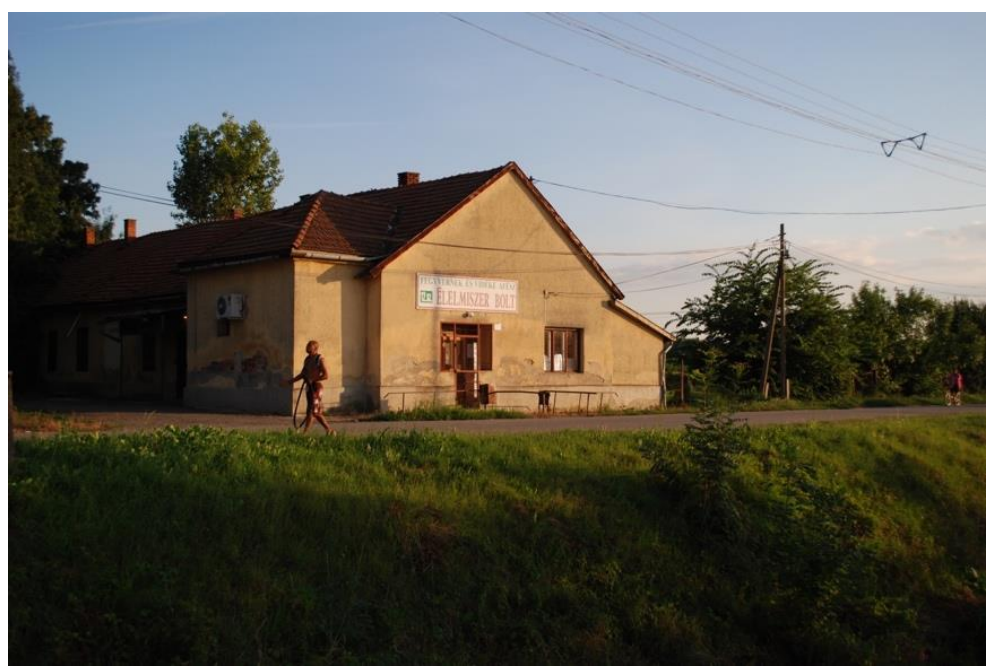

Készitette: MITRIK DÓRA 
21. kép - Tiszabői utcakép, üresen álló telekkel

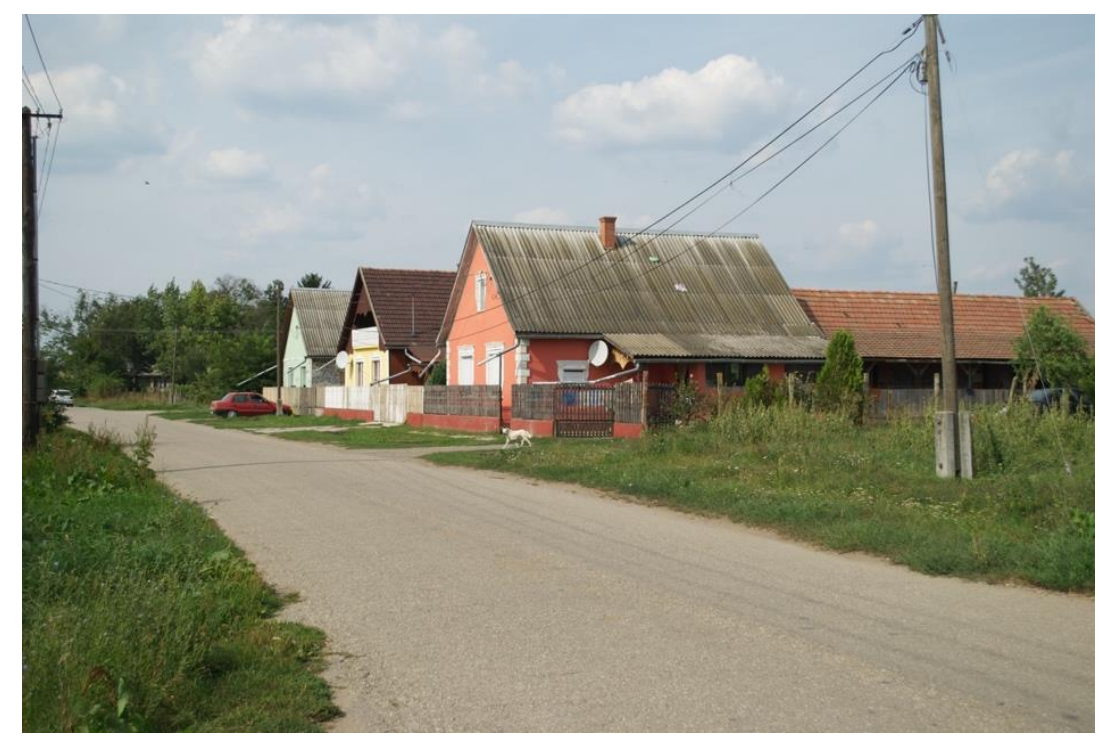

Készitette: MITRIK DÓRA

22. kép - Tiszabői utcakép, üresen álló telekkel

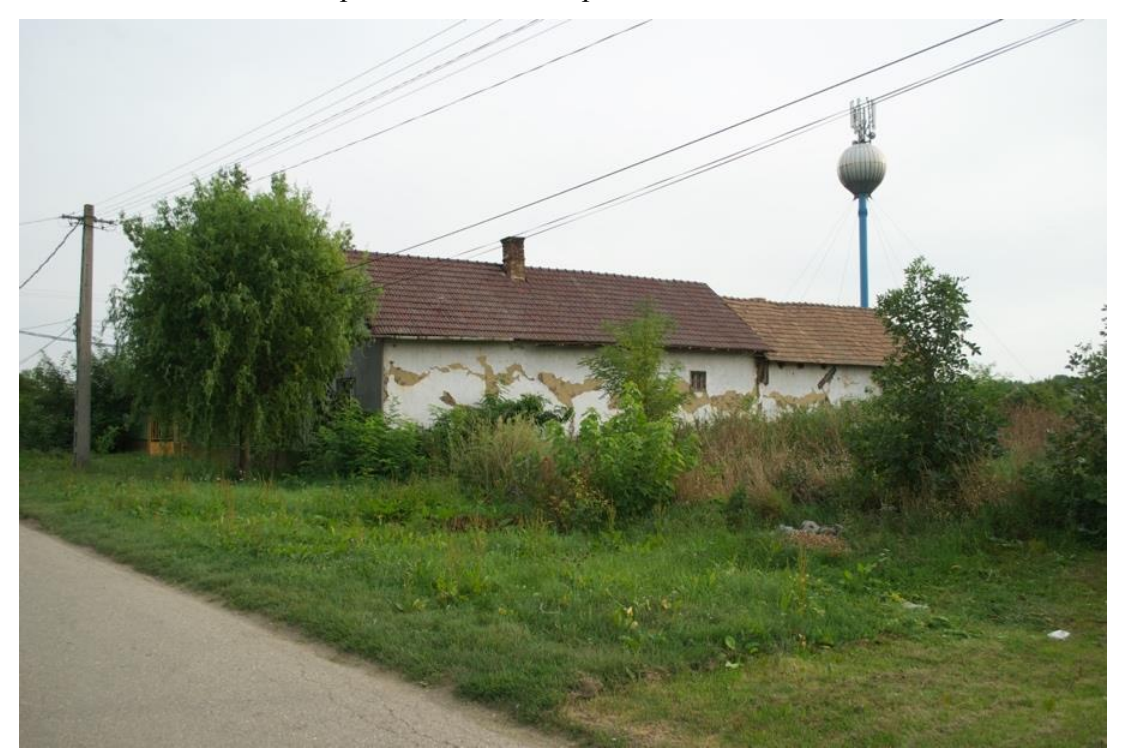

Készitette: MITRIK DÓRA 
Melléklet 5. - Szolnok, Törteli úti szegregátumról készült fényképek

23. kép - A Törteli úti szegregátum „A” sorának látképe

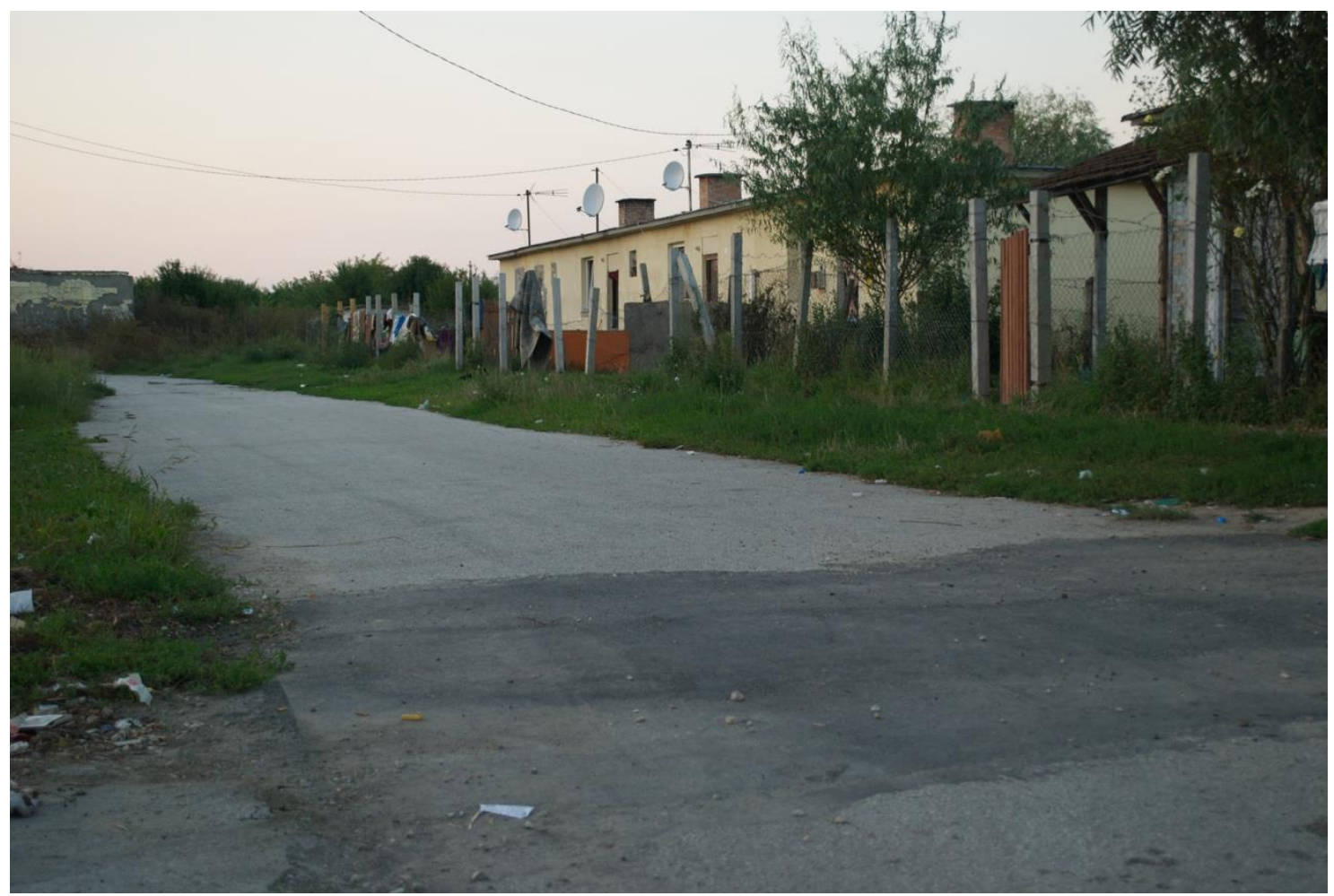

Forrás: SAJÁT KÉPEK

24. kép - Felújitott ingatlan a Törteli úti szegregátumban

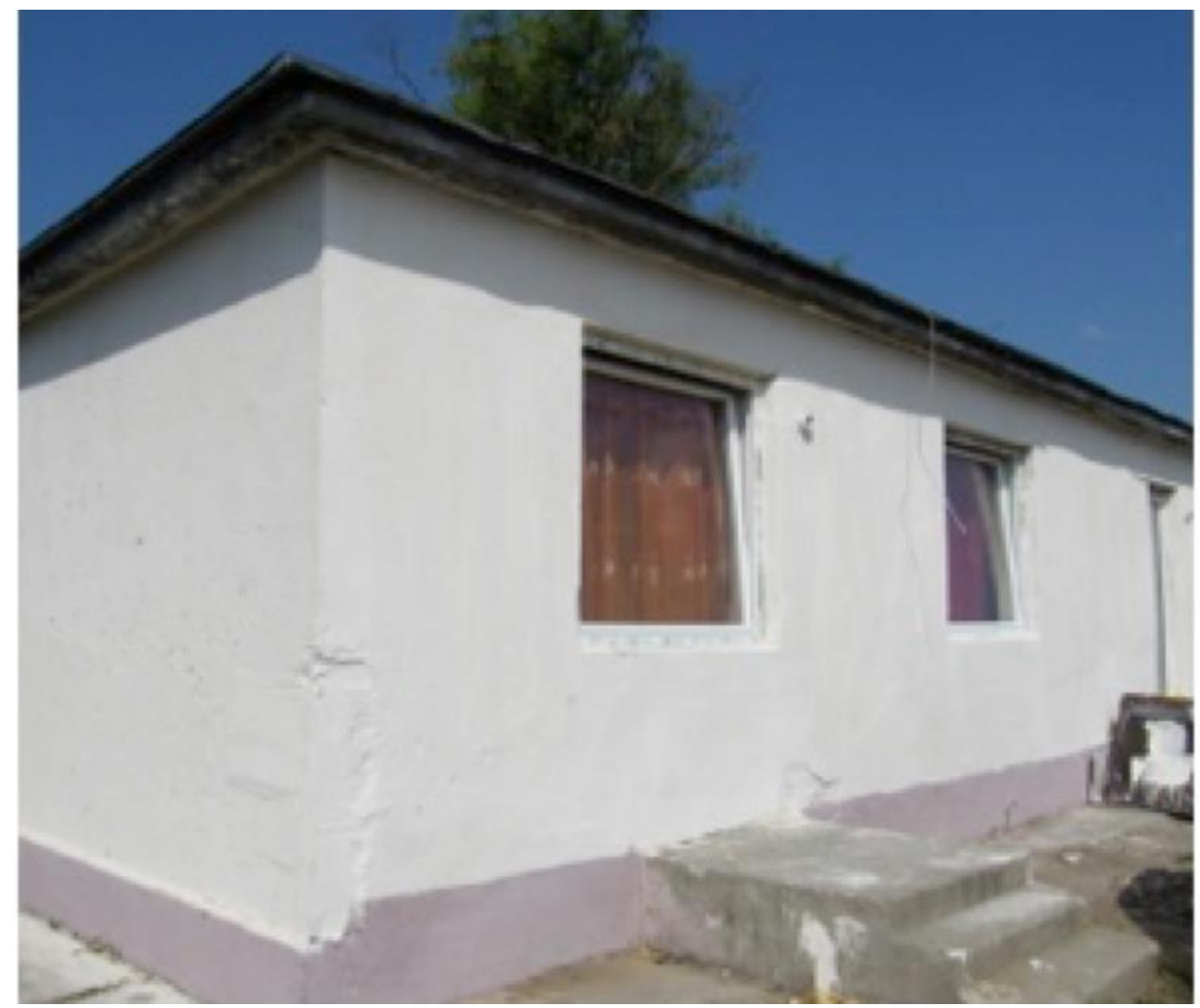

Forrás: SAJÁT KÉPEK 
25. kép - A Törteli úti szegregátum környezetének látképe 1.

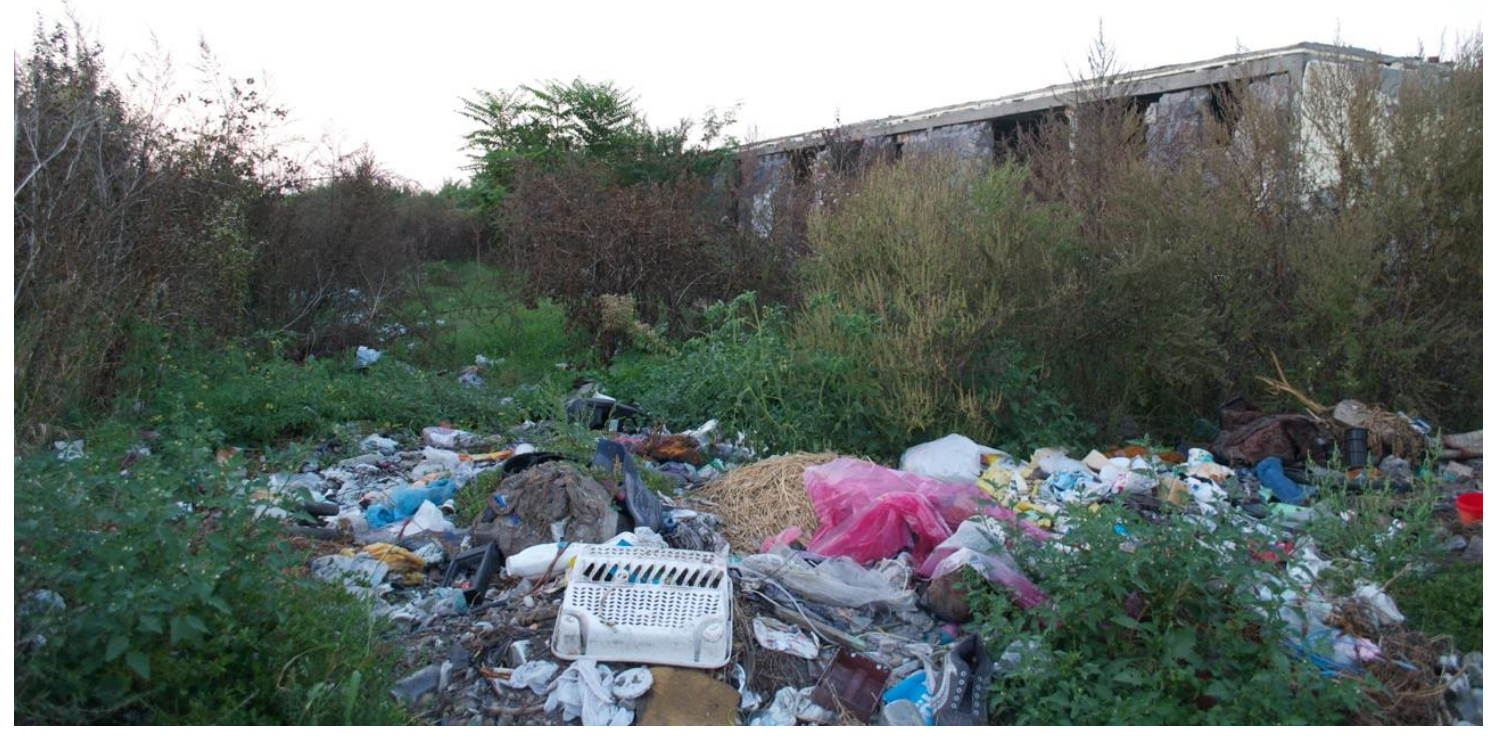

Forrás: SAJÁT KÉPEK

26. kép - A Törteli úti szegregátum környezetének látképe 2.

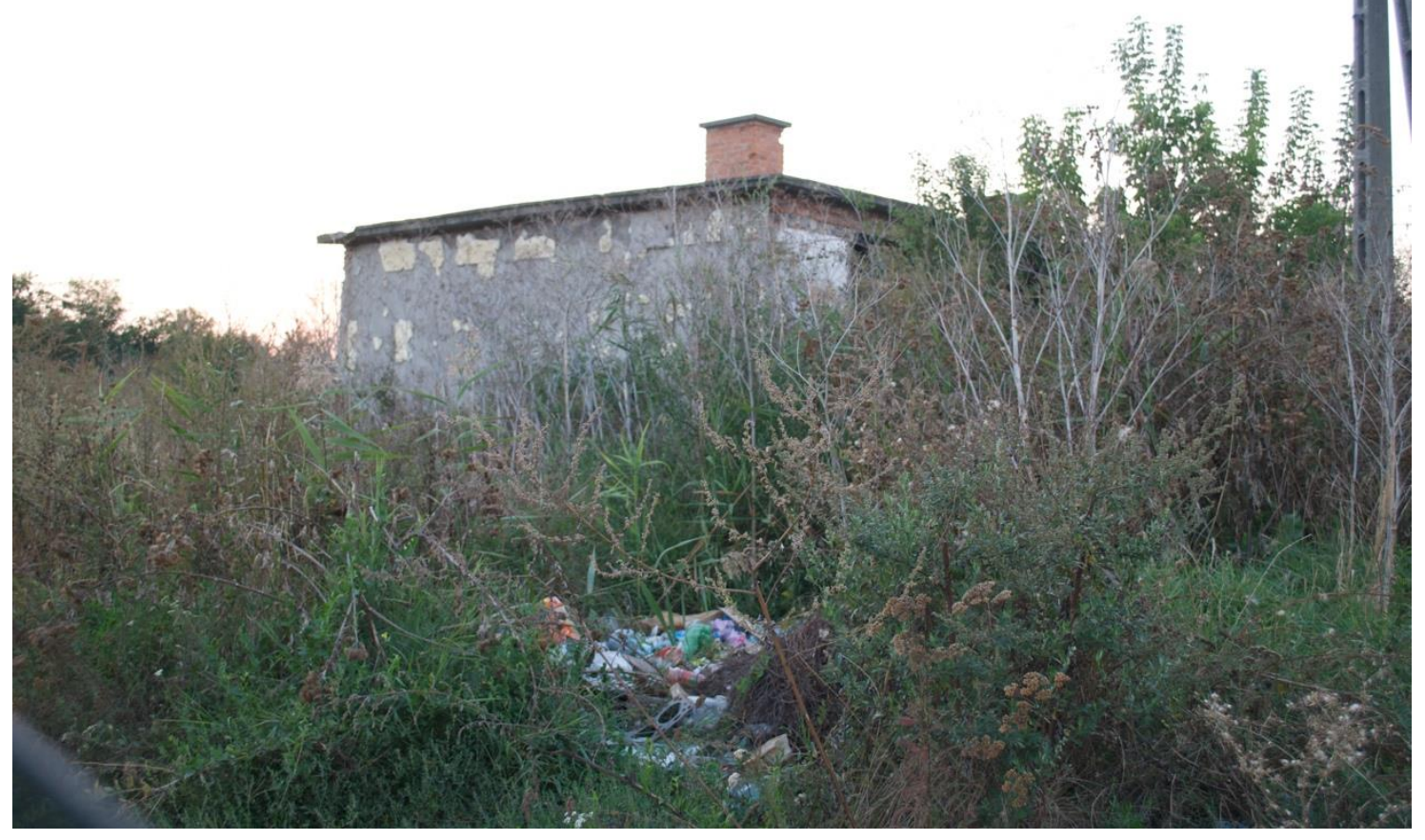

Forrás: SAJÁT KÉPEK 
27. kép - Egykor használatban lévő ingatlanok a Törteli úti szegregátumban

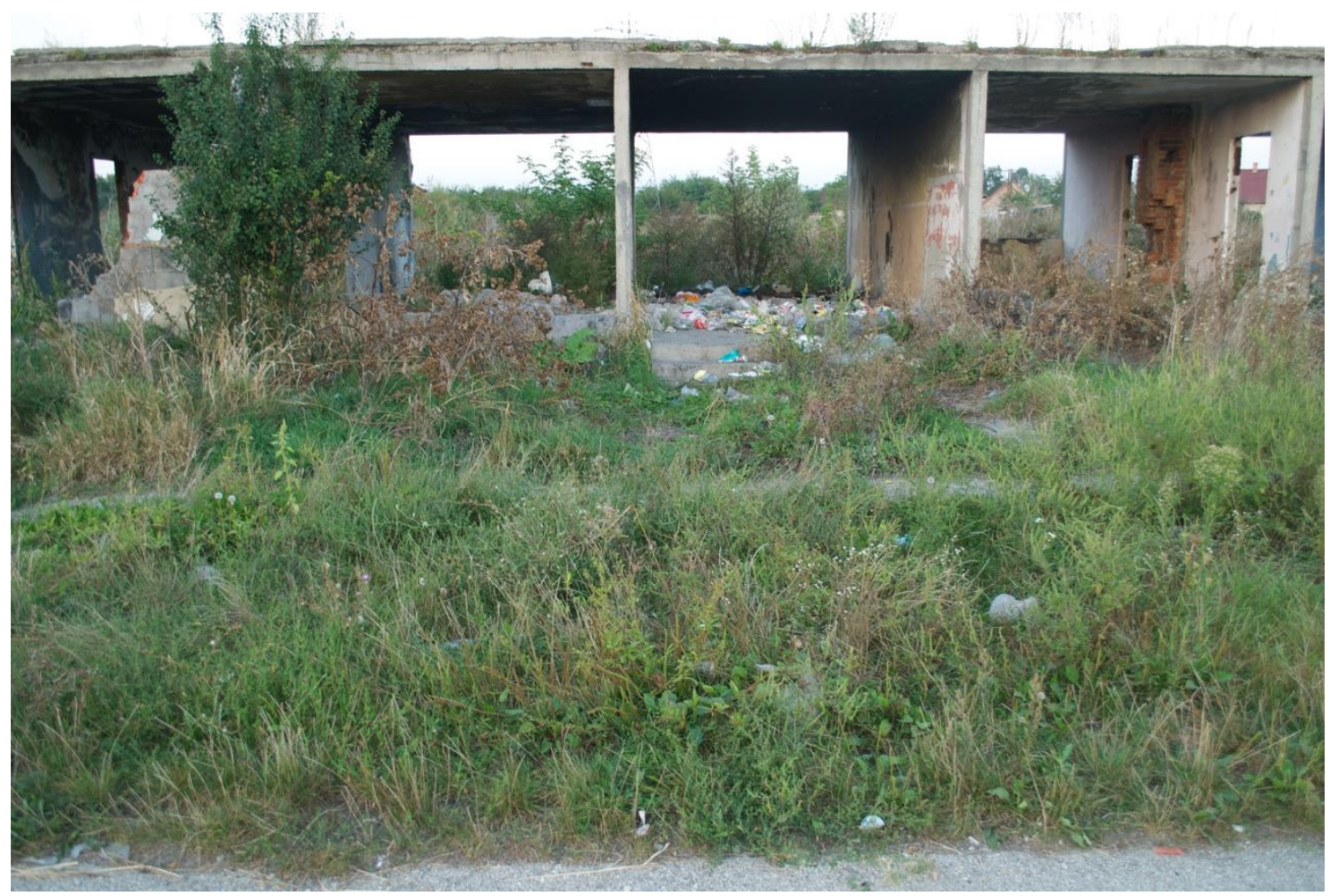

Forrás: SAJÁT KÉPEK

28. kép - A telep közepén összeállitott konténerház épitése

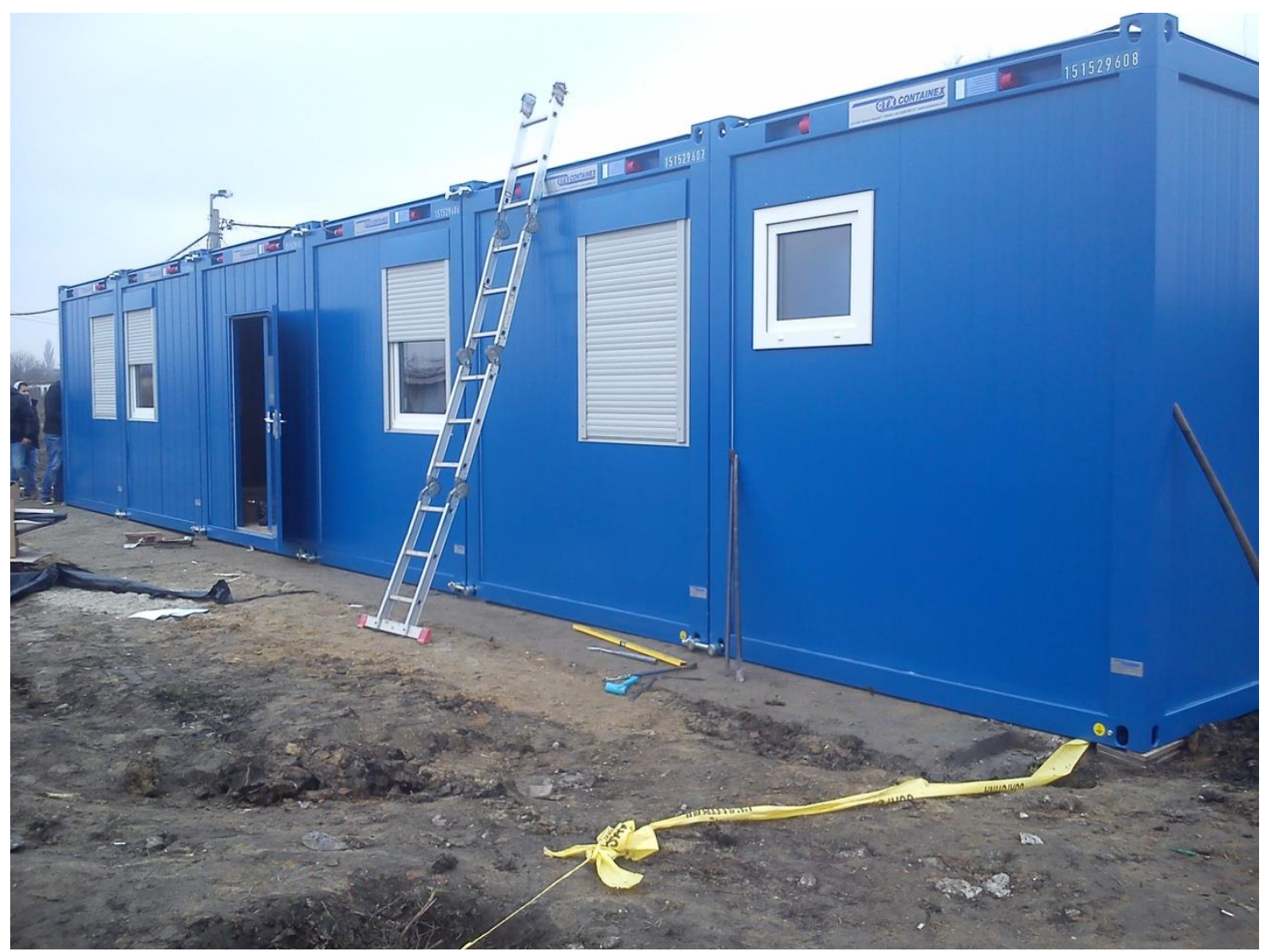

Forrás: SAJÁT KÉPEK 